UNIVERSIDADE DE BRASÍLIA

INSTITUTO DE ARTES

\title{
A DIMENSÃO EMOCIONAL NO DESIGN DO MÓVEL BRASILEIRO
}

Ana Claudia Maynardes

Documento apresentado ao Programa de Pós-Graduação em Arte, Universidade de Brasília, como requisito para obtenção de título de Doutora em Artes.

Orientadora: Profa. Dra. Elisa de Souza Martinez

Brasília, DF 
Ficha catalográfica elaborada automaticamente, com os dados fornecidos pelo(a) autor(a)

Maynardes, Ana Claudia

M471d A dimensão emocional no design do móvel brasileiro / Ana Claudia Maynardes; orientador Elisa de Souza Martinez. -- Brasilia, 2015.

$243 \mathrm{p}$.

Tese (Doutorado - Doutorado em Arte) -Universidade de Brasília, 2015.

1. design emocional. 2. design de produto. 3. mobiliário doméstico brasileiro. I. Martinez, Elisa de Souza, orient. II. Título. 


\section{ANA CLAUDIA MAYNARDES}

\section{A DIMENSÃO EMOCIONAL NO DESIGN DO MÓVEL BRASILEIRO}

Documento apresentado para obtenção do título de Doutora em Artes junto ao Programa de Pós-graduação da Universidade de Brasília

COMISSÃO EXAMINADORA

Profa. Dra. Elisa de Souza Martinez (orientadora)

Departamento de Artes Visuais - IdA/UnB

Prof. Dr. Vicente Martinez Barrios

Departamento de Artes Visuais - IdA/UnB

Profa. Dra. Fátima Aparecida dos Santos

Departamento de Desenho Industrial - IdA/UnB

Profa. Dra. Andrea Castelo Branco Judice Pesquisadora

Núcleo de Multimídia e Internet-NMI/UnB

Profa. Dra. Grace Maria de Freitas

Departamento de Artes Visuais - IdA/UnB

Brasília, março de 2015 
Para meu filho Pedro, o "pequeno grande sol" que me ilumina, para Denis, meu marido e companheiro, para Wilma, minha mãe, minha fortaleza, e para meu pai, "vovô pisicão", in memorian 


\section{AGRADECIMENTOS}

À minha orientadora, professora Elisa de Souza Martinez, pela confiança, dedicação, paciência e generosidade.

À minha família, Wilma e Percy (in memorian), Graciela e Junior, Marcos e Denise, que sempre estiveram ao meu lado.

Ao meu marido Denis, que foi pai e mãe durante um longo período.

Ao meu filho Pedro, que sempre compreendeu a ausência da mãe.

Aos meus amigos, "criaturas do bem", Thérèse, Fred, Andrea, Dimitri, Gilmar, Havane, Geni, Fátima, Dani, Nisete, Itiro.

Às mães de plantão, Yanna, Ailta, Élida, Giselli, Fernanda e Maruska.

Aos meus queridos companheiros do LDD/DIn/UnB, pela dedicação em minha ausência.

A Sergio Rodrigues, in memorian, e Claudia Moreira Salles, pelas informações e entrevistas concedidas.

Aos colegas do Departamento de Desenho Industrial/UnB, pela confiança e apoio.

Aos professores e servidores do Programa de Pós-Graduação em Arte/UnB. 


\section{RESUMO}

Esta pesquisa avaliou que o atual processo projetual do designer direciona os objetos a caminhos em que aspectos emocionais são considerados ou privilegiados como construtos, por meio de uma investigação das "qualidades" ou características evidenciadas nos objetos que desencadeariam respostas emocionais. Verificou como se desenvolve e se orienta a criação ou o projeto de objetos com características emocionais. A percepção das emoções por meio das funções dos objetos está diretamente associada aos aspectos sociais, culturais e de percepção do indivíduo, pois são eles que determinarão a intensidade do interesse pelo objeto e diversificarão as formas de compreensão, de interação e de utilização. Assim, este trabalho analisou e entendeu quais são e como são embutidos os pressupostos simbólicos, estéticos, culturais e sociais nos produtos a ponto de serem considerados "objetos emocionais". O setor moveleiro no Brasil foi escolhido representativo para esta pesquisa, que objetivou compreender e descrever os aspectos, as qualidades e as características emocionais do móvel doméstico brasileiro, considerando o projeto do móvel "de autor"; e identificou nessas características as relações estabelecidas com o "design emocional". Ao analisar os móveis Poltrona Mole, de Sergio Rodrigues; Cadeira Vermelha, dos Irmãos Campana; e Banco Siri, de Claudia Moreira Salles, buscou-se perceber como suas características proeminentes aguçam o processo subjetivo do indivíduo e abrem para um processo de significação. Quanto ao objeto emocional, foi definido como aquele que está apto a oferecer ressignificações e ressimbolizações ao longo do cotidiano imediato e da vida do sujeito: propõe estórias, permite trocas, e possibilita que a história do sujeito seja contada por meio de suas relações.

Palavras-chave: Design emocional. Design de produto. Dimensão emocional. Mobiliário brasileiro doméstico. 


\begin{abstract}
Through an investigation of the "qualities" or characteristics of objects capable of triggering emotional responses, this paper evaluated that the current design process followed by designers leads objects to paths where emotional aspects are considered and privileged as constructs. It analyzed how the process of creating or designing objects with emotional characteristics is developed and directed. The perception of emotions through an object's functions is directly associated with an individual's social, cultural and perception aspects, as these will determine the intensity of interest in the object and promote new forms of understanding, interaction and use. In this regard, this paper analyzes and shows what are the symbolic, aesthetic, cultural and social assumptions and how they are embedded in the products to the point of being considered "emotional objects." The Brazilian furniture sector was chosen as representative for this paper, which aimed at understanding and describing the aspects, qualities and emotional characteristics of domestic furniture in Brazil, considering designer furniture pieces, and identified the relationships established with "emotional design" in these characteristics. In analyzing the furniture pieces Poltrona Mole, by Sergio Rodrigues, Cadeira Vermelha, by the Campana Brothers, and Banco Siri, by Claudia Moreira Salles, this paper sought to understand how their prominent characteristics sharpen an individual's subjective process and lead to a process of signification. Emotional objects were defined as those capable of giving new meanings and symbolizations during the individual's immediate and daily life: they propose stories, enable exchanges and allow for the individual's story to be told through his or her relationships.
\end{abstract}

Keywords: Emotional design. Product design. Emotional dimension. Domestic furniture in Brazil. 


\section{LISTA DE FIGURAS}

Figura 1 - Gustav Hassenpflug: mesa de dobrar em três posições diferentes, 1928 .......................... 25

Figura 2 - Smartphones que adaptam-se às dinâmicas das relações de uso .................................. 31

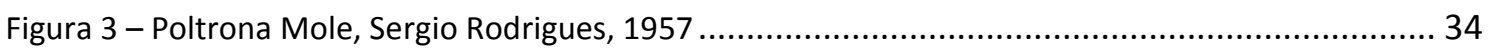

Figura 4 - Peças da campanha publicitária do Grupo Pão de Açúcar .......................................... 40

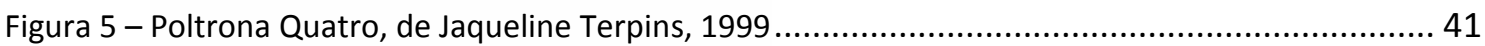

Figura 6 - Representação das categorias do design segundo estudos da emoção ............................ 42

Figura 7 - Perspectivas sobre emoções, Person (2003). Adaptado pela autora .............................. 44

Figura 8 - Classificação das emoções, Damásio (2004) e (2006). Adaptado pela autora ...................... 50

Figura 9-Comparação entre as emoções geradas e tipos de design ........................................... 51

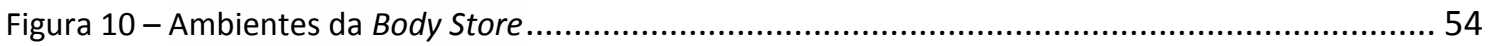

Figura 11 - Processo experiencial, perceptivo e emocional .............................................. 60

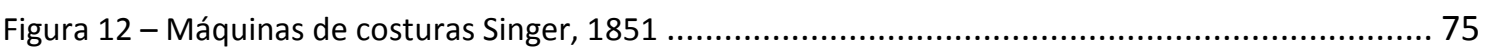

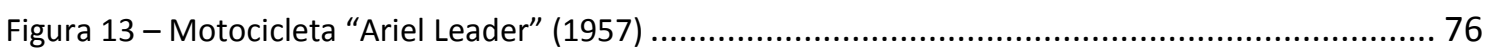

Figura 14 - Conjunto de mesa e cadeiras Saisu Chairs ........................................................... 78

Figura 15 - Bowl com forma de gato. Autor desconhecido .................................................. 84

Figura 16 - Poltrona Cadê - de Luciana Martins e Gerson de Oliveira, 1995.................................87

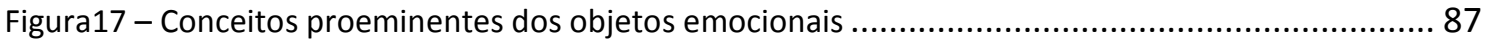

Figura 18 - Exemplo da mobília grega ..................................................................... 91

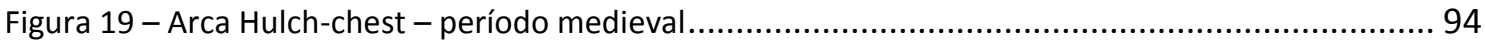

Figura 20 - Faldistório; Trono de Dagoberto; Arca-banco - período medieval ................................ 96

Figura 21 - Cadeira estilo renascentista Savonarola ............................................................. 98

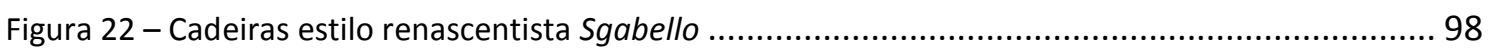

Figura 23 - The Music Lesson, c. 1662-65; Jan Vermeer...................................................... 100

Figura 24 - Cadeira esculpida em carvalho com motivos marinhos; e Cadeira Luís XIV, 1675............ 102

Figura 25 - Cômoda, 1774; Escrivaninha, móvel com gavetas e compartimentos, 1768 .................. 104

Figura 26 - Bancos variados. Características estético-afetivas ou semissimbólicas ........................ 107

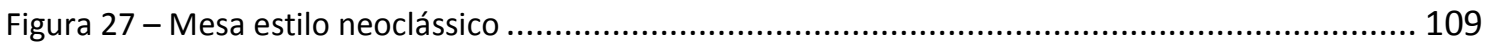

Figura 28 - Ambiente em que a produção de tecidos era feita em meio à vida doméstica ................ 111

Figura 29 - Catálogo dos móveis Morris \& Company...................................................... 113

Figura 30 - Mesa estilo art nouveau ......................................................................... 115

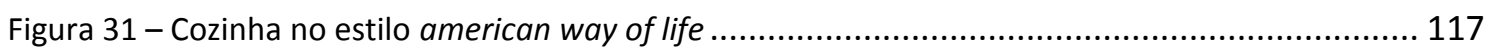

Figura 32 - Cozinha da Microbial Home (2011), da Philips ...................................................... 122 
Figura 33 - Sofás (chaise longue) para home theater.

Figura 34 - Índios Matis (Amazonas) deitados na rede; rede do século XIX; poltrona Rede,

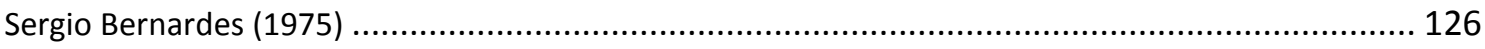

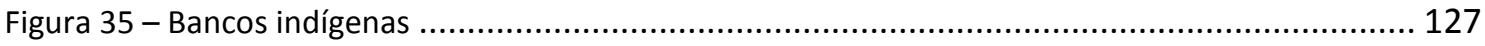

Figura 36 - Jirau indígena; e prato contemporâneo inspirado nas tradições indígenas: uso do jirau.... 128

Figura 37 - Móvel com aplicação da técnica do charão (verniz negro) e incrustações - século XIX;

e peça com a técnica do alfarje. Caixas marchetadas por Maqueson Pereira/PA (2012) e encaixes

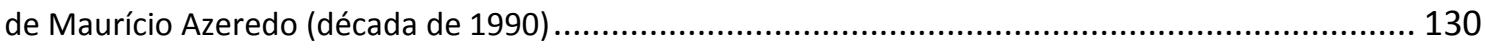

Figura 38 - Contador. Móvel indo-português, séculos XVI-XVII ............................................ 131

Figura 39 - Cama de bilros, estilo indo-português (séc. XVII) ................................................. 131

Figura 40 - Mesa de aba ou cancela, estilo renascentista (séc. XVIII); e mesa manuelina ou de "bolacha",

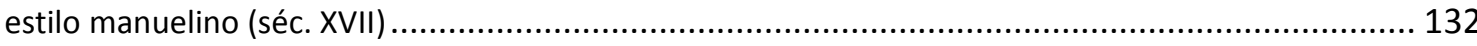

Figura 41 - Móveis de guarda. Cômoda de jacarandá, estilo D. João V (século XVIII) e cômoda rústica, estilo D. José V (século XVIII)

Figura 42 - Móveis de guarda e de utilidade. Armário português de carvalho, estilo nacional-português (século XVII) e bufê ou bufete campesino (século XVIII).

Figura 43 - Móveis de guarda e de descanso. Cofre ou baú (século XVIII) e cadeira de campanha, artesanato popular (século XVIII)

Figura 44 - Arca-banco e meia-cômoda com pernas de valete. Estilo barroco (século XVIII)

Nota-se, na meia-cômoda, as botas que calçam os pés do valete.

Figura 45 - Arca ou caixa colorida. Estilo barroco mineiro (século XVIII) 138

Figura 46 - Preguiceiro com uso da palhinha (século XIX); Marquesa de Oscar Niemeyer e Anna Maria Niemeyer, 1974

Figura 47 - Mesa de encostar D. Maria I, estilo neoclássico (final do século XVIII) e cômoda prateleira D. José I, estilo neoclássico (século XIX)

Figura 48 - Canapé Sheraton Brasileiro, estilo Sheraton (século XIX); cadeira Beranger, estilo Beranger; banco bandeirante, artesanato popular (século XIX); e cama catre, artesanato popular (século XIX)... 140 Figura 49 - Canapé Beranger e detalhe, estilo Beranger (século XIX) . 141

Figura 50 - Cadeira Cimo, décadas de 1920 e 1930 - simplicidade, funcionalidade e economia 144

Figura 51 - Sala de estar de 1930, com móveis e objetos desenhados por Warchavchik 145

Figura 52 - Joaquim Tenreiro. Cadeira de balanço, em jacarandá da Bahia e assento em couro, 1947; Cadeira de Três Pés, em imbuia, pau-marfim, jacarandá, roxinho e mogno, 1947. 147

Figura 53 - Lina Bo Bardi. Mesa e cadeira Girafa, 1987; Poltrona Bowl (Bardi's Bowl), década de 1950148 Figura 54 - Poltrona MF5 com estrutura em madeira e encosto de palhinha - Móveis Preto \& Branco; e espreguiçadeira, de madeira compensada e assento e encosto de fita plástica - Móveis Z , 1949....... 150 
Figura 55 - Michel Arnoult, Linha Peg-Lev. Desmontável, em pau-ferro, com assento e encosto de couro

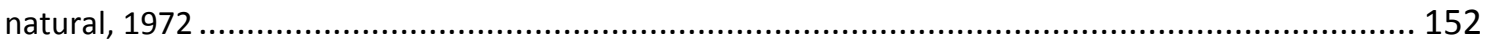

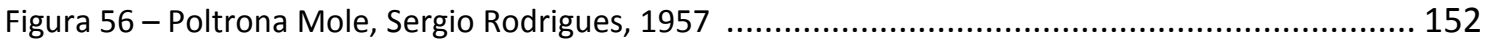

Figura 57 - Lina junto à cadeira dobrável projetada para o auditório do Sesc Pompeia, 1947, e cadeira

Frei Egídio, 1987 158

Figura 58 - Poltrona Kiko para o Salão de Atos da Reitoria; croquis para a poltrona do Auditório Dois Candangos, Universidade de Brasília, década de 1960 160

Figura 59 - Cadeira Lúcio Costa, 1956, e Poltrona Mole, 1957 161

Figura 60 - Cadeira chifruda, 1962, e poltrona Kilin, 1973 161

Figura 61 - Poltrona Julia, 1980, e poltrona Diz, 2001 161

Figura 62 - Poltrona Móveis Z - recorte curvo na madeira compensada, década de 1950 ...... 163

Figura 63 - Namoradeira - Zanine Caldas, década de 1980 163

Figura 64 - Revisteiro Eixo 7 (1998), cadeira Mulher (1989) e mesa lateral Inex (s.d.) .................... 166

Figura 65 - Conjunto de mesa e cadeira, e balanço Amor Perfeito (instalação para o MCB, 2014) ...... 168

Figura 66 - Banco Ressaquinha, muirapiranga e pau-ouro (1988); e banco da série Do Avesso.......... 170

Figura 67 - Cadeira Vermelha, 1993, e cadeira Favela, 1991 .............................................. 173

Figura 68 - Cadeira Chita ..................................................................................... 174

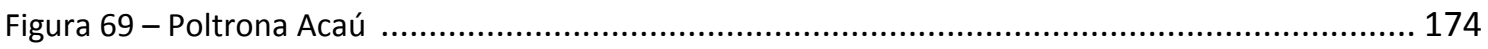

Figura 70 - Poltrona Casta (2006), totalmente desmontável, e banco Siri, 2008 .......................... 178

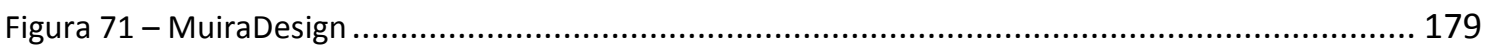

Figura 72 - MuiraDesign. Rack com aplicação do módulo Trama 1 .......................................... 180

Figura 73 - Mesa Ripa, cadeira Quadri e banco Bar, de Zanini de Zanine Caldas ........................... 182

Figura 74 - Banco Boleadeira (2013) e poltrona São Luís (2007), de Flávia Pagotti......................... 182

Figura 75 - Poltrona Mole, de Sergio Rodrigues (1957/1961) .......................................... 185

Figura 76 - Cadeira Vermelha de Irmãos Campana (1993) ................................................. 185

Figura 77 - Banco Siri de Claudia Moreira Salles (2008) ...................................................... 185

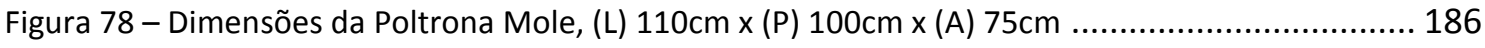

Figura 79 - Desenho da Poltrona Mole, por Sergio Rodrigues ......................................... 187

Figura 80 - Estrutura fixa da Poltrona Mole................................................................ 187

Figura 81 - Desenhos esquemáticos e ilustrativos da Poltrona Mole, realizado por Sergio Rodrigues . 188

Figura 82 - Poltrona Mole na versão em couro da cor branca ................................................ 189

Figura 83 - Sergio Rodrigues utilizando a Poltrona Mole de forma relaxada e informal................... 190

Figura 84 - Uso da Poltrona Mole em ambiente que propõe relaxamento ................................... 192

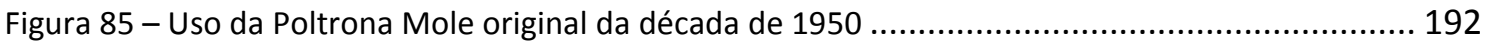


Figura 86 - Uso da Poltrona Mole em ambientes diversos e com diferentes tipos de acabamentos do

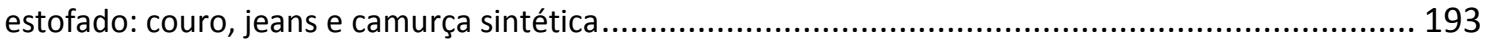

Figura 87 - Sergio Rodrigues ilustra uma simpática história sobre a criação da Poltrona Mole ........... 194 Figura 88 - Alguns exemplares da Família Tacape: bancos Sonia e Mocho; mesas Arimello e Burton; Sofá Mole e Cadeira Cantu

Figura 89 - Poltrona Mole (batizada fora do Brasil como Sheriff), de 1962, com as travessas curvas e a primeira versão da Poltrona Mole, de 1957, com as travessas retas e as auxiliares 196

Figura 90 - Ilustração de Sergio Rodrigues demonstrando o uso "descontraído" e "relaxado" que a poltrona proporciona, e o estofado envolvendo o corpo como um cobertor 197

Figura 91 - Aplicação do capitonê tradicional e o aplicado na Poltrona Mole ................................ 198

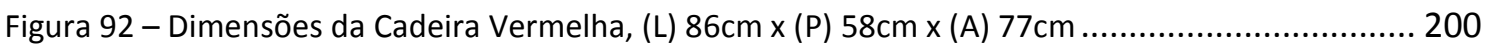

Figura 93 - Estrutura e materiais da Cadeira Vermelha ...................................................... 202

Figura 94 - Ponteiras em alumínio nas hastes que formam o encosto ..................................... 202

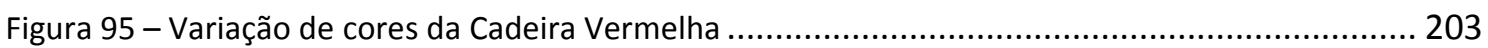

Figura 96 - Processo de entrelaçamento da corda realizado pelo artesão Giuseppe Altieri ............... 204

Figura 97 - Detalhe da configuração dos laços e nós da Cadeira Vermelha .................................... 206

Figura 98 - Efeito do desgaste e da descoloração das cordas nos primeiros modelos ...................... 207

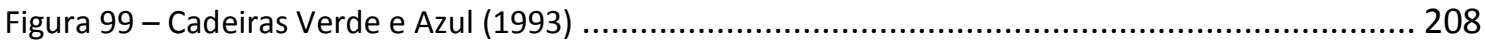

Figura 100 - Diferentes efeitos da variação do trançado da corda nos modelos produzidos .............. 209

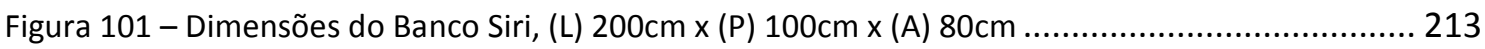

Figura 102 - Desenho esquemático do encosto do Banco Siri (adaptado pela autora) .................... 214

Figura 103 - Detalhes do Banco Siri - eixo pivotante; uso do capitonê; encosto fabricado com refugo de ripas de madeira

Figura 104 - Esquema de produção dos encostos com reaproveitamento de madeiras e curvamento das

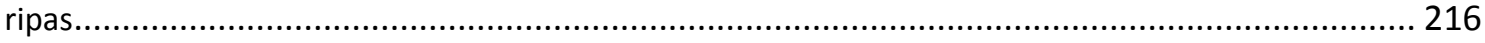

Figura 105 - Esquema de montagem do estofado..................................................... 216

Figura 106 - Banco Siri utilizado como divisor e integrador de ambientes ............................... 217

Figura 107 - Banco Siri utilizado como divisor de ambientes

Figura 108 - Utilização do Banco Siri - de avantajado dimensionamento, o móvel proporciona posições diversas de descanso.

Figura 109 - Utilização do Banco Siri - interação de usuários e ambientes proporcionada pelo uso dos encostos giratórios

Figura 110 - Desenho esquemático do encosto da Poltrona Siri com dois eixos fixos.

Figura 111 - Poltrona Siri com variação de acabamento do estofado/assento 
SUMÁRIO

INTRODUÇÃO

PARTE I - A SITUAÇÃO DO OBJETO EM USO: DAS RELAÇÕES EMOCIONAIS E DAS FUNÇÕES

1 UM OUTRO OLHAR PARA OBJETO: DESIGN EMOCIONAL................................. 21

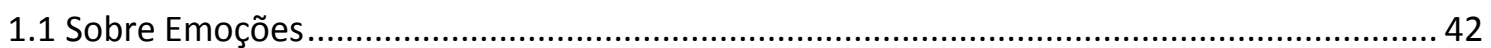

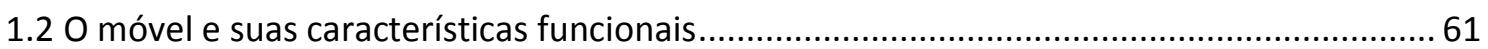

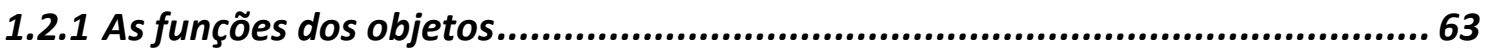

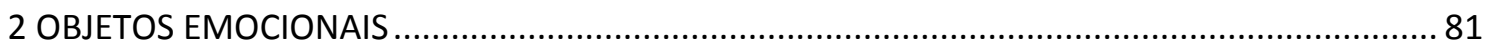

PARTE II - O DESIGN DE MOBÍLIA: EM BUSCA DE REFERÊNCIAS SIMBÓLICAS E EMOCIONAIS

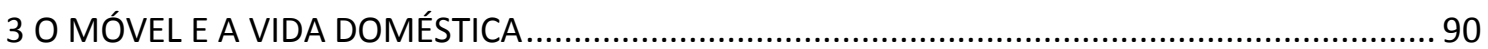

3.1 O mobiliário e suas relações: a domesticidade, a privacidade e o conforto..........................99

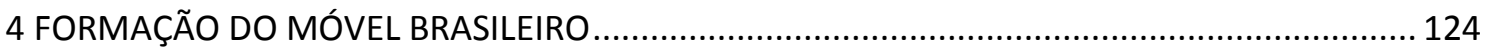

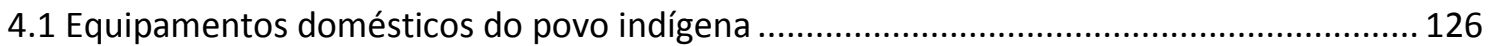

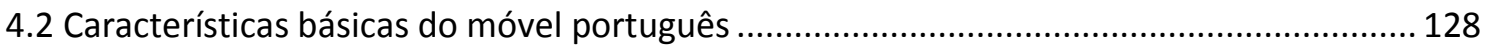

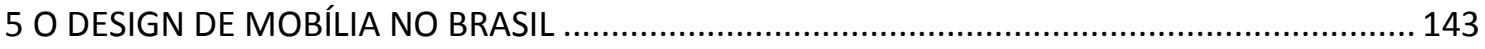

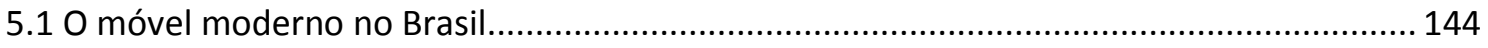

5.2 Design de Mobília Contemporânea: conceitos formadores ............................................. 155

5.2.1 Pioneiros e Contemporâneos ............................................................... 156

5.2.2. Absorvendo (ou dissolvendo) o modernismo......................................... 164

5.2.3 A brasilidade no móvel..................................................................... 166

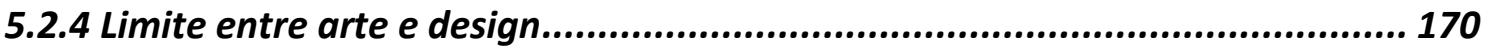

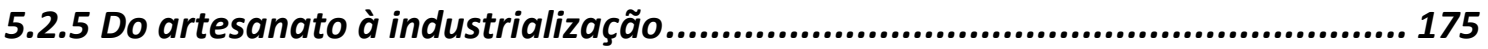

5.2.6 Design conceito: nova geração .......................................................... 180

PARTE III - A EMOÇÃO NO DESIGN DO MÓVEL BRASILEIRO

6 MOLE, VERMELHA, SIRI: CONCEITOS “MÓVEIS" ......................................... 184

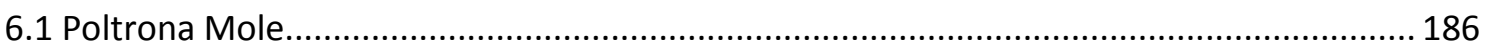

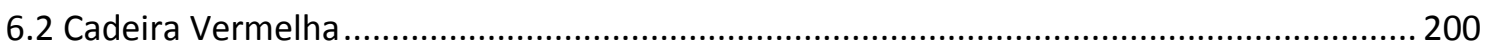

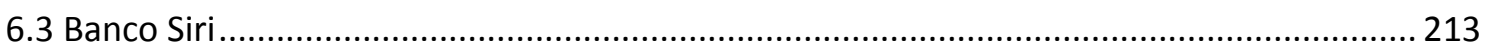

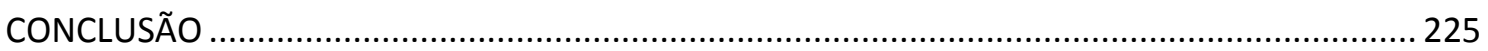

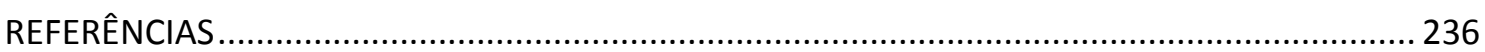




\section{INTRODUÇÃO}

Observa-se que o atual processo projetual do designer direciona os objetos a caminhos em que aspectos emocionais são considerados e/ou privilegiados como construtos. Nesta pesquisa deslocamos o olhar para uma investigação das "qualidades" ou características evidenciadas nos produtos que desencadeariam respostas emocionais. Interessa-nos aqui verificar como se desenvolve e se orienta a criação ou o projeto de produtos com características "emocionais".

Vários autores vêm discutindo e estudando sobre as emoções desencadeadas pelos produtos. Cada qual com sua especificidade e linha teórica. Assim, surgem algumas sugestões teóricas, outras práticas, outras metodológicas. Contudo, como resultado a todas as linhas, nota-se que uma se torna comum: a dependência do entendimento sobre o indivíduo subjetivo e sua interação com o meio físico, cultural e social.

Com base nessa assertiva, além do discurso comunicativo proporcionar aos objetos uma autonomia quando projetados com intenção de seduzir ou atender aos desejos de um usuário, o objeto, por si, é capaz de provocar reações emocionais nos indivíduos por meio de suas múltiplas funções.

A percepção das emoções suscitadas pelos objetos está diretamente associada aos aspectos sociais, culturais e de percepção do indivíduo, pois são eles que determinarão a intensidade do interesse pelo objeto e diversificarão as formas de compreensão, de interação e de utilização.

Para Norman (2006), além da forma física e funções mecânicas, os objetos assumem "forma social” e "funções simbólicas". Para Kripperdorff (1996), já não se objetiva o design centrado no objeto autônomo e seus aspectos técnicos e objetivos, mas sim no design pautado no ser humano e seu modo de ver, interpretar, conviver e suas relações com o entorno. $\mathrm{O}$ autor pondera que os objetos não são mais considerados “coisas" e sim práticas sociais, símbolos e preferências, e que não reagimos apenas às qualidades físicas das "coisas", mas ao que elas significam para nós.

Por esse motivo, o foco da pesquisa será analisar e entender quais são e como são embutidos os pressupostos simbólicos, estéticos, culturais e sociais nos produtos a ponto de serem considerados "objetos emocionais".

Como setor representativo para este trabalho, foi escolhido o setor moveleiro no Brasil. Essa escolha se deu a partir da história e do desenvolvimento do design de 
móveis no país. Questões que abrangeram desde a herança cultural dos equipamentos indígenas; a influência europeia trazida para o Brasil colônia; a mudança de paradigma causada pela inserção dos propósitos modernistas; o processo de industrialização; as características formais e estruturais das peças, assim como a maneira como os designers tratam da questão emocional no processo de criação, foram ponto de partida para a pesquisa.

Observa-se de antemão, por uma análise histórica, que o design do móvel no Brasil tem a madeira como elemento básico para a constituição de sua linguagem, seja no plano funcional, técnico e construtivo, seja no plano formal, expressivo e simbólico. Essa condição procede, aparentemente, da abundância de espécies verificadas no vasto território e da forte presença da madeira no cotidiano do país, remontando à sua herança colonial. Situação que configurou o que podemos entender como uma "tradição", baseada na mão de obra e produção artesanal, abrangendo os utensílios para o uso cotidiano, o mobiliário e a própria casa.

A evidência do desdobramento dessa condição pode ser observada em uma cultura de projeto do móvel moderno e contemporâneo, que foi configurada ao longo do período de gestação, afirmação e reconhecimento do movimento moderno brasileiro, na arquitetura e no mobiliário.

A pesquisa tem como objetivo compreender e descrever os aspectos, as qualidades e as características dos objetos emocionais no móvel doméstico brasileiro considerando o projeto do móvel "de autor", e identificar nessas características as relações estabelecidas com o "design emocional". Achamos que esta categoria representa melhor o que buscamos.

Entendemos o design como uma atividade que tem a função de produzir objetos que fazem a mediação entre o ser subjetivo e a intersubjetividade, colocando objetos (projetos) no mundo não apenas para o uso, mas para a reflexão por meio do uso em uma relação dialógica. Aos designers cabe a tarefa de se situarem entre a sua própria subjetividade e a subjetividade do outro dentro do sistema intersubjetivo. Assim, adotamos a postura do autor-criador (BAKHTIN,1992), aquele que trabalha com a noção de dialogismo e toma como pressuposto que o objeto só pode ser pensado a partir de uma forma de mediação e interação dos indivíduos. Deste modo, os interlocutores são simultaneamente autores e atores, pois a percepção do outro é parte integrante do discurso do eu. O eu e o outro são, então, aqueles que fazem o processo de design acontecer. 
Os trabalhos programados e a leitura da bibliografia levaram a uma pré-seleção tipológica - móveis de descanso: banco, poltrona, cadeira - formada por três peças produzidas no Brasil por diferentes autores. A análise desse grupo representativo leva a esclarecer as várias dimensões das funções dos produtos sob a ótica da "emoção".

A hipótese é demonstrar que o atualmente denominado "design emocional" se configura no design de móveis no Brasil desde a sua implantação; e que tais elementos há muito constituem uma linguagem específica do móvel brasileiro.

Por uma questão metodológica dividimos esta tese em três partes, subdivididas em seis capítulos.

A primeira parte, denominada $A$ situação do objeto em uso: das relações emocionais e das relações funcionais, contém o capítulo 1 e o capítulo 2 e tem uma característica teórica e mais abrangente. Assumimos esta postura, pois vimos a necessidade de explicitar primeiramente o que entendíamos acerca das relações emocionais e dos objetos emocionais de uma maneira geral, sem nos focar especificamente no objeto nosso de estudo: os móveis brasileiros.

Na primeira parte do capítulo 1, desenvolvemos textos acerca dos conceitos de design emocional. Defendemos a ideia de que design emocional é quando desenhamos produtos capazes de despertar reações que nos "afetam" de algum modo. Inicialmente discorremos sobre conceitos de afeto, emoção, sentimento, sentidos, sensações, percepções e experiência, tendo como base teorias que mesclam conceitos cognitivistas e socioconstrutivistas. A partir das proposições do neurocientista António Damásio (2000 e 2006) e do psiquiatra Daniel Siegel (2004) - enriquecidas por autores como Izquierdo (2002), Kandel; Schwartz e Jessel (1997), Dutcosky (2007), Pisani et al. (2000) e Durie (2008), entre outros, que defendem a associação entre corpo e mente como um elemento uno, não havendo separação entre o sentir e o pensar para existir - é que desenvolvemos nosso pensamento.

Neste capítulo apresentamos uma discussão acerca das categorias dos objetos "móveis" e suas funções, como também a teoria do design emocional. Autores como Moles (1981) e Barthes (1978) são utilizados para delimitar e definir o conceito de “objeto" e suas relações. Löbach (2000), entre outros autores, nos dão base teórica para categorizações das funções que os objetos assumem. Assim, em decorrência desse levantamento de conceitos, propusemos uma classificação própria. Para esse trabalho definimos que os objetos são classificados em três funções básicas: funções semissimbólicas; funções práticas ou de uso; e funções técnicas. 
$\mathrm{Na}$ categoria funções semissimbólicas, desenvolvemos um pequeno estudo acerca dos conceitos que o símbolo assume nas diversas áreas do conhecimento, por meio dos pressupostos de Kant, Goethe, Cassirer, Durand, Jung, Ricoeur, Peirce e Floch, para propormos nossa definição. Para tanto, defendemos a ideia de que há uma íntima ligação entre questões estéticas e simbólicas nos produtos e que estas são interrelacionadas, e que também são dependentes à percepção do indivíduo subjetivo e sua relação intersubjetiva, partindo dos pressupostos de que a função semissimbólica é aquela que proporciona e intensifica a experiência emocional.

Para as funções práticas ou de uso, desenvolvemos a ideia que diz respeito à execução da tarefa ou à ação de uso propriamente dita, baseada nos autores Löbach (2000), Iida (1990), Ferrara (1986).

Já para as funções técnicas, propomos uma definição de que são aquelas que traduzem tecnicamente as questões estético-simbólicas e as práticas ou de uso, utilizando Ono (2004) e Iida (1990) como referência.

No capítulo 2 propomos uma definição do que seria um objeto emocional. Definimos como aquele que está apto a oferecer ressignificações e ressimbolizações ao longo do cotidiano imediato e da vida do sujeito: propõe estórias, permite trocas, e que a história do sujeito seja contada por meio de suas relações. Para tanto recorremos aos autores Moles (1981); Baudrillard (1993) e Didi-Huberman (1998).

A segunda parte do trabalho, Design de mobília: em busca de referências simbólicas e emocionais, faz um apanhado essencialmente histórico situando a utilização do móvel como categoria de equipamento doméstico que ora se apresenta como objeto com características proeminentes das funções práticas ou de uso, ora das funções técnicas, ora das funções semissimbólicas. Está dividida em três capítulos. O capítulo 3 analisa a formação do móvel enquanto utensílio utilitário e equipamento funcional e sua transformação em utensílio estético e simbólico dentro da formação da casa, do lar e dos conceitos de domesticidade e privacidade. A intenção é localizar as inter-relações dessa categoria de objeto - móvel - com a formação do espaço e da vida doméstica. São utilizados autores como Rybczynski (1999), Boyle (1993), Lemos (1989), Oates (1991), Forty (2007) e Argan (1992), que de uma maneira geral convergem para o eixo de discussão de que a configuração do mobiliário reflete as estruturas familiares, sociais e culturais de uma época.

O quarto capítulo é dedicado à análise sobre o móvel no Brasil, o locus da pesquisa. Apresenta a primeira fase da formação do móvel no país e algumas questões 
sobre os equipamentos domésticos indígenas que influenciaram posteriormente a concepção e produção de peças do mobiliário, assim como os hábitos cotidianos, e a inserção do móvel português e europeu no Brasil colônia. Foi realizada uma análise histórica sobre as influências estilísticas, produtivas, de materiais, bem como culturais e sociais. Para isso foram utilizados autores como Santos (1995), Canti (1985), Lemos (1978 e 1989), Costa (1975) e Bayeux (1997).

O capítulo 4 está relacionado ao móvel doméstico e à habitação no Brasil. Analisa a utilização do móvel como objeto utilitário e simbólico diante das tantas influências que decorreram dos períodos pré-colônia e colônia, colocadas no capítulo anterior. Analisa o período que é considerado fundamental para o surgimento e implantação do que se denomina de "móvel brasileiro": o moderno na mobília e na casa brasileira. Os autores considerados foram Bayeux (1997), Lemos (1989) e Santos (1995).

O capítulo 5 é dedicado à análise dos pressupostos e condicionantes que nos levam ao desenvolvimento do móvel contemporâneo. Nesse item, deixamos clara a intenção de que trabalhamos nesta tese com a categoria "móvel de autor". Essa prerrogativa baseia-se em cinco questões fundamentais: é um objeto que não possui tantas interferências dos processos industriais padrões; propicia o diálogo que se estabelece entre o indivíduo, o móvel e o designer, enquanto designer-criador; não está à mercê de influências estilísticas e mercadológicas; sugere maior diversidade de diálogos; e por fim, propõe processos de significações mais identificáveis. Acreditamos que será por meio dessas cinco vertentes que conseguiremos partir para uma análise mais profunda quanto aos aspectos simbólicos e emocionais do objeto. Navegamos no limiar entre as funções semissimbólicas, práticas ou de uso e funções técnicas para estabelecer as vertentes conceituais que fundamentaram o objetivo principal deste trabalho: entender a relação emocional entre indivíduo e objeto, tendo como estudo de caso três peças representantes do design do móvel brasileiro.

Para tanto, classificamos em seis os aspectos que nos nortearam para o estabelecimento de conceitos finais.

O primeiro aspecto levantado foi a abordagem realizada pelos "pioneiros", relacionada à concretização da cultura material brasileira e à autenticidade da ideia da busca pelas raízes matriciais do país. Discutimos as obras de Lina Bo Bardi, Sergio Rodrigues e Zanine Caldas. O segundo aspecto são as influências do modernismo 
dentro do conceito contemporâneo de morar. Nesse item foram enfatizadas as obras do designer Pedro Useche.

A brasilidade nos móveis ou identidade nacional é o terceiro tópico levantado. Esse item veio em decorrência de princípios analisados nos itens anteriores e que geraram características que foram se sedimentando no imaginário coletivo como sendo legitimadores das raízes culturais e simbólicas de brasilidade, como os códigos visuais da cultura popular brasileira; os materiais nativos; as técnicas de produção (fazer artesanal, encaixes, marchetarias); e o próprio fazer artesanal (o ser humano e sua manualidade). Para tanto, foram analisados alguns produtos da Marcenaria Baraúna e do designer Maurício Azeredo. O quarto aspecto, limite entre arte e design, trata do mobiliário contemporâneo como um dos representantes da classe de objetos utilitários que mais passa por experimentações que discutem os limites entre utilidade e dimensão cultural. Aqui aparecem as obras dos Irmãos Campana e Sérgio Matos como representantes.

O quinto tópico aborda questões que analisam os processos artesanais estabelecidos e aplicados no setor moveleiro. Etel Marcenaria, Claudia Moreira Salles e MuiraDesign são os representantes analisados. O sexto e último tópico coloca a produção da nova geração de designers. Essa produção é definida como aquela que faz da memória afetiva o seu novo valor, ou que considera o designer como um "escultor" e a forma por ele produzida deixa de ser um simples complemento da função de uso ou de várias atividades adjacentes ao sistema produtivo para tornar-se uma expressão individual correspondente ao novo pensamento.

Por fim, na Parte III, A emoção no design do móvel brasileiro, o capítulo 6 é dedicado a uma análise de três peças selecionadas como representantes de objetos emocionais por nós definidos: Poltrona Mole, de Sergio Rodrigues (1957); Cadeira Vermelha, dos Irmãos Campana (1993); e Banco Siri, de Claudia Moreira Sales (2008).

Aqui foram destacadas algumas discussões baseadas nas teorias e conceitos realizados. Como argumento principal do trabalho, sustentamos o conceito das emoções como aquelas que são ligadas ao universo particular do indivíduo e geradas a partir de experiências vivenciadas em algum momento de sua formação cultural e social. Como eixo metodológico, definimos que as emoções são condicionadas pelo contexto, pela memória e pela formação do indivíduo. Assim, para entender como o objeto móvel constitui-se em objeto emocional, construímos três categorias de fatores de análise. A primeira categoria está relacionada à análise dos elementos que formam a situação 
material do objeto: suas características formais e de produção; a segunda diz respeito ao(s) contexto(s) de uso(s): o uso, o ambiente e a permanência. A outra categoria faz vistas à percepção: modos de ver, experiência e interação.

A partir desses três grupos partimos para a análise dos objetos Poltrona Mole, Cadeira Vermelha e Banco Siri, e como suas características proeminentes aguçam o processo subjetivo do indivíduo e abrem para um processo de significação.

Nas conclusões que tiramos com essa pesquisa e na discussão acerca dos pressupostos que orientam o design emocional no mobiliário brasileiro, identificamos como características principais, as fortes vertentes históricas que remontam ao passado da formação do mobiliário no Brasil; a independência dos atuantes do setor às interferências quando da época da implantação da indústria no Brasil; e a não subordinação desses mesmos atuantes às prerrogativas funcionalistas à época da implantação do ensino do design no país.

Por fim, reconhecemos que algumas observações inseridas ao longo do texto estão baseadas no próprio exercício da atividade profissional da autora, ora pelo exercício acadêmico, como docente, ora pela prática, como designer. 


\title{
PARTE I - A SITUAÇÃO DO OBJETO EM USO: DAS RELAÇÕES EMOCIONAIS E DAS FUNÇÕES
}

\begin{abstract}
[...] a essência de um sentimento (o processo de viver uma emoção) não é uma qualidade mental ilusória associada a um objeto, mas sim a percepção direta de uma paisagem específica: a paisagem do corpo.
\end{abstract}

(DAMÁSIO, 2006)

Cadeiras, sofás, relógios, smartphones, talheres, automóveis, sapatos, caixas eletrônicos... é fato que vivemos cercados por uma gama de objetos que fazem o nosso cotidiano tornar-se cada vez mais ágil, confortável e - porque não - mais feliz. Contudo, é fato também que muitas vezes esses mesmos objetos tornam-se empecilhos em nossas vidas, como relatam Norman (2008) e Flusser (2007).

Considerados por Flusser (2007, p. 193) como "obstáculos para remoção de obstáculos", os objetos de uso devem ter a capacidade de tornarem-se mediações/mediadores entre as pessoas. Assim, devem deixar de pertencer à categoria de "objetivos, problemáticos" e passarem a ser objetos "intersubjetivos e dialógicos".

A esta parte do trabalho foi dedicado um estudo de como a percepção dos objetos em situação de uso nos é colocada e quais relações entre o objeto e o indivíduo devem ser observadas para que o objeto se torne mais dialógico e intersubjetivo. Tem um caráter aberto de análise, pois não foca apenas o mobiliário brasileiro, objeto desta tese, mas objetos de design como um todo são tomados como exemplo para um maior entendimento da atuação do design e do designer.

Uma das proposições são os estudos sobre a relação emocional existente entre estes dois atores da relação: objeto e indivíduo. Assim, utilizamos as teorias postuladas pelos estudos do Design Emocional, a partir de Norman (2008), e definimos como "objeto emocional" aquele que poderá empreender esse papel de mediador intersubjetivo.

Partimos de estudos acerca das emoções e afetos, tendo como referência algumas proposições teóricas e práticas, e consideramos o neurocientista António Damásio como fonte singular para o desenvolvimento do pensamento. Apresentamos também quais são as funções que os objetos devem possuir e assumir em nossas vidas, assim como qual a postura que o designer, enquanto aquele que configura tais objetos, o autor-criador, deve adotar para que a mediação emocional aconteça. 


\section{UM OUTRO OLHAR PARA OBJETO: DESIGN EMOCIONAL}

Há pouco tempo, a possibilidade de se projetar com a noção de que os indivíduos têm a capacidade de constituir relações afetivas com os produtos que os rodeiam era ainda ignorada e estranha para muitos. No Brasil, os primeiros sintomas dessa nova proposição se fizeram sentir na palestra "Form Follows Spirit"

${ }^{1}$ de Alexander Manu, na qual pontuou que os designers deveriam projetar ações em vez de objetos e deveriam não só pensar em formas tangíveis e na satisfação única das necessidades práticas dos usuários, mas no "espírito", no indivíduo, no ser que iria utilizar aqueles objetos.

Aquilo que Manu advertira tinha relação, por exemplo, às propostas racionalfuncionalistas primeiramente iniciadas pela Deutsche Werkbund, seguidas pela Bauhaus e culminando na Hfg Ulm (Escola de Ulm), que tanto influenciaram a prática do design na Europa e no Brasil por décadas.

A Deutsche Werkbund, ${ }^{2}$ que tinha como um dos grandes representantes Hermann Muthesius, defendia a tese de que deveria haver um "padrão" como instrumento para a racionalização da produção. Era argumentado que o produto alemão deveria ter uma forma objetiva, caracterizando, assim, um estilo próprio. Os designers faziam a depuração das formas pela simplificação, pela padronização e pela função social das artes.

Em meio a crises sociais e decepções políticas no período pós-guerra ( $1^{\mathrm{a}}$ Guerra Mundial), é aberto um espaço na Alemanha para o surgimento da Bauhaus, em 1919, e do Instituto de Pesquisa Social de Frankfurt, em 1924, que, em seus pressupostos intelectuais e grande parte da produção material, converteram-se em matrizes críticas do design.

Nesse sentido, a Bauhaus e o Instituto de Pesquisa Social de Frankfurt, com sede em instituições de ensino, convergiram para uma análise de problemas culturais. Sendo valorizada como objeto de análise, a cultura é avaliada sob diferentes ângulos e acende

\footnotetext{
${ }^{1}$ Palestra proferida na Universidade Católica do Paraná, em 1994. Alexander Manu é um profissional que trabalha com inovação estratégica. Ensina "Inovação, Prospectiva e Business Design" na Rotman School of Management; é professor na Universidade OCAD em Toronto, e professor visitante no Instituto McCain Wallace para o Empreendedorismo.

${ }^{2}$ Liga Alemã do Trabalho, criada em 1907 com o propósito de valorizar o trabalho, relacionando arte, indústria e artesanato.
} 
a diversas abordagens de aspectos ligados à produção material e ideológica. Colocamse, então, os fundamentos filosóficos da produção e as formas dos produtos em exame.

Essas duas escolas, tendo características distintas, difundiram suas abordagens a partir de um movimento reflexivo, desenvolvendo teorias e manifestações artísticas de conteúdo crítico. Baseando-se ora no formalismo, ora no marxismo, elas colaboraram para a conformação do design contemporâneo.

No Movimento Moderno, o termo função sintetiza um sistema coordenado de proporções físicas visando a satisfazer um conjunto de necessidades. As funções são entendidas enquanto relações dinâmicas da estrutura, de modo que função e estrutura sejam conceitos complementares. O objeto é compreendido como um conjunto de relações entre as partes, em que todos os fatos são observados e descritos de modo que sejam determinadas leis gerais para a definição de um modelo que o caracterize. Com este modelo simula-se a realidade, em que se pretende prever a função ou a dinâmica das relações (Bomfim, 1998). O modelo estrutural-funcional foi empregado por Jan Mukarovský (1981) em seus trabalhos sobre a função dos objetos, que mais tarde foram utilizados como métodos de análise das funções dos produtos industriais. Mukarovský ressalta a função pedagógica dos objetos industriais, quando se refere à aplicabilidade deles. Considera que todos os objetos, dos mais simples aos mais sofisticados tecnologicamente, são dotados de elementos pedagógicos que explicitam o objeto pelo próprio uso, por meio de processos de aprendizagem voltados ao seu manuseio.

Nesse sentido, o período "funcionalista", advindo das proposições dos estudos que derivaram do termo "função", forneceu por muito tempo princípios, regras e leis que foram utilizadas para análise e classificação na definição dos objetos. Assim, os objetos advindos da produção industrial e sua aplicação são submetidos à lei de seleção segundo suas capacidades funcionais (Bomfim, 1998).

A Bauhaus, fundada pelo alemão Walter Gropius em $1919,{ }^{3}$ tinha como diretiva fundamental "superar fronteiras formais ou conceituais entre artes puras e aplicadas, artesanais e industriais, artes menores e maiores, conferindo racionalidade à produção criativa", (Batista, 2000, p.15).

\footnotetext{
${ }^{3}$ Objetivando o estudo da relação arte e indústria, desenvolveu reflexões e métodos de análise sobre o funcionalismo formal. Adotou como pressuposto o estudo de estruturas formais adequadas à sociedade moderna, por meio de uma premissa básica: a arte moderna demanda o uso de técnicas industriais, ainda que, em seus primeiros anos, mantenha a ênfase em técnicas artesanais. O seu lema transformou-se em tecnologias modernas com novas soluções formais, novas linguagens e novos signos, direcionando a arte para atender as massas.
} 
A escola infunde a "funcionalidade" à formação artística, partindo do princípio de que todo projeto artístico está relacionado à perspectiva de construção da forma. Essa objetividade conclamada por Gropius integrava os projetos artísticos às crescentes demandas sociais. Sob esse aspecto, a arte moderna estaria predestinada a se tornar um suporte da produção industrial apta a atender as massas. O objetivo de "unir a arte à técnica" e de socializar a produção artística ganha maior ênfase no projeto de Hannes Meyer, que dirigiu a escola no período entre 1928-1930.

Em evidência, a função dos objetos determina os atributos e os critérios fundamentais para o desenvolvimento de projetos. A característica do "menos é mais", assinalada por Mies Van der Rohe, encabeça a tentativa de retirar os elementos desnecessários e sinaliza a importância do despojamento formal nos objetos utilitários. Nesse sentido, a simplicidade da forma proporcionaria o uso racional dos objetos, levando a uma pedagogia da forma realizada pelo uso desses objetos.

De um prisma político-ideológico e econômico, essa fase é caracterizada pela excessiva importância dada ao objeto, visto que o que se propunha era o "produto universal", um produto que levasse a arte às massas dentro de um contorno socioeconômico. O objeto se tornaria independente de influências individuais, gostos, modismos, estilos e gestos, dando margem a uma autonomia funcional jamais vista.

Ao longo do século XX, a significação do objeto foi concebida a partir de vários pontos de vista que correspondem a determinada corrente de pensamento, consoante às diversas filosofias. Nos anos de 1930, a significação foi definida a partir do conceito de "pragmatismo" postulado por Wittgenstein que, na procura de um método para explicar e fazer compreender a realidade objetiva, acrescenta que o significado refere-se também ao uso (CONSIGLIERI, 2000).

Ao considerar o uso como elemento principal da significação, Wittgenstein o define por meio da testabilidade, em uma dimensão semântica de significação mínima de uma série de usos de forma apropriada. A funcionalidade baseada em métodos lógico-mecanicistas dos anos 1930 a 1950 apresenta como expoentes Walter Gropius e Le Corbusier, que condicionavam as suas formas nos organogramas funcionais de melhor uso do objeto. Foi dentro dessa máxima que o pensamento funcionalista foi norteado: a função ditando o uso apropriado do objeto.

Le Courbusier, defensor do axioma da casa como uma "máquina de morar" que deveria incluir apenas os móveis e utensílios estritamente necessários ao cumprimento de tarefas, desvinculava qualquer aproximação entre o indivíduo e o objeto que não 
fosse o uso utilitário. Em um de seus textos (LE COURBUSIER,1996) afirma categoricamente que os objetos de uso cotidiano (móveis e utensílios) não deveriam ser utilizados ou concebidos como "objetos-sentimento ou objetos-vida", e sim como “objetos-padrões”, que teriam como função tornar a vida doméstica mais simples e menos desgastante. Em nada esses objetos-padrões deveriam ser considerados estéticos, sentimentais ou emocionais. Os objetos-padrões serviam apenas para atender às "necessidades-padrões" do ser humano que realizava tarefas e gestos semelhantes no cotidiano. Assim, os objetos-padrões eram considerados como "objetos-prolongamentodos-membros-humanos", diferentemente dos objetos-sentimento ou objetos-vida, criados pelos "artistas decorativos" que, segundo ele, em nada contribuíam para amenizar ou auxiliar as tarefas cotidianas (necessidades-padrões).

O Funcionalismo concede um peso prioritário e, em princípio, exclusivo à função pragmática e em sua tipologia de uso, e a famosa fórmula de L. Sullivan - "a forma segue a função"-toma seu lugar de destaque.

Os produtos do Funcionalismo pretendem estar claramente determinados por sua função pragmática. Isso, segundo Moles (1981), introduzirá uma ideia de rigor, de disciplina e, por isso, de asceticismo.

A forma pensada sem a função primeira, leia-se utilitária, foi combatida, os teóricos do design elevaram à categoria de dogma a obediência ao Funcionalismo, no qual se tinha o fundamento do princípio criador. Um objeto não deveria pretender mais que exercer sua função utilitária, e para isso teriam que ser levados em consideração todos os dados científicos, técnicos e formais. Segundo Gropius, os objetos eram fabricados de acordo com as próprias leis, sem adornos supérfluos e sem detalhes estilísticos. As leis às quais Gropius se referia são, sem sombra de dúvida, aquelas funcionais utilitárias. O Funcionalismo buscava um padrão formal que pudesse substituir a imensa variedade de estilos que caracterizava a produção da indústria e a onerava. Esse padrão deveria eliminar a subjetividade intrínseca dos designers e dos usuários no processo de percepção e avaliação, ou seja, a forma não seria mais constituída a partir do gosto ou de variantes individuais ou culturais, mas sim pela razão. Paradoxalmente esse funcionalismo exagerado desembocou na criação de um novo estilo. 

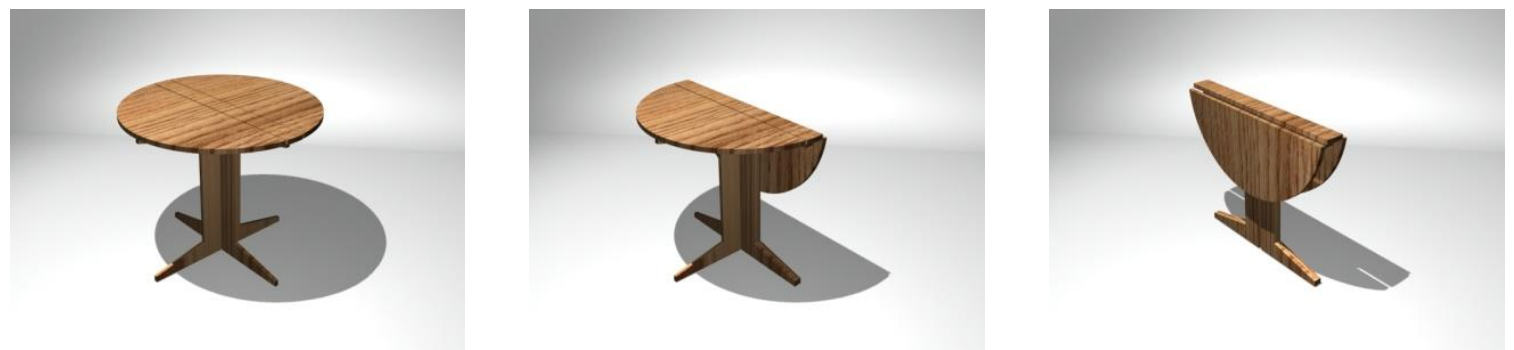

Figura 1 - Gustav Hassenpflug: mesa de dobrar em três posições diferentes, 1928. A mesa completamente dobrada tem $9 \mathrm{~cm}$ de largura

Sem dúvida, a rigidez do princípio funcionalista levou paradoxalmente à concepção de certos produtos que, além de sua aparente funcionalidade, não são mais que uma resposta estilístico-formalista ao problema pleiteado. Pode-se citar aqui o estilo funcional das arquiteturas e dos objetos sobrecarregados de referências ao mundo da indústria e da técnica.

A filosofia funcionalista inicialmente desenvolvida pela Bauhaus e baseada na teoria tautológica, teve seus ecos e encontrou sua máxima repercussão até meados da década de 1960, com a fundação da Hochschule für Gestaltung (Escola Superior da Forma) em Ulm, Alemanha. O pensamento tautológico ditado pela teoria lógica algébrica ou formal sugere a nova lógica para o pensamento científico, que se refletiu intensamente no design entre as décadas de 1930 e 1970. Com esse conhecimento lógico ou racional, a forma passou a ser concebida sob os conceitos da teoria científica, distanciando-se, desse modo, todo e qualquer caráter sensorial da forma. O princípio do Funcionalismo produziu objetos que eliminaram toda a emoção, para impor objetos ditos específicos, que não pediam outra coisa senão serem vistos e usados por aquilo que são, dando a eles um caráter tautológico na medida em que se constituíam em objetos com intenções puramente funcionais utilitárias.

O olhar tautológico faz com que se recusem as latências do objeto ao afirmar como vitória a identidade manifesta, funcional, tautológica. Dessa maneira se recusa a temporalidade, o trabalho do tempo ou da metamorfose no objeto; o trabalho da memória no olhar, a subjetividade do indivíduo.

[...] uma vitória maníaca e miserável da linguagem sobre o olhar, na afirmação fechada, congelada, que aí não há nada mais que um volume, e que esse volume não é senão ele mesmo [...] esse objeto que 
vejo é aquilo que vejo, nada mais.". (DIDI-HUBERMAN, 1998, p. 39)

Sob a perspectiva de Didi-Huberman (1998), consideramos os objetos do período funcionalista como aqueles que pretendem eliminar toda construção temporal, a subjetividade, e que permanecem no tempo presente de sua experiência do visível, permanecendo no que se vê, ou melhor dizendo, para qual uso/função ele foi proposto.

Baudrillard (1993) fala sobre os objetos modernos ou funcionais, frutos da industrialização e da sociedade técnica, e entende que essas características idealizadas, quando imputadas aos objetos, foram construídas pelo homem.

O projeto vivido de uma sociedade técnica é o questionamento da própria idéia de Gênese, é a omissão das origens, do sentido dado e das "essências" cujos símbolos concretos foram os bons velhos móveis: é uma computação e uma conceitualização práticas sobre a base de uma abstração total, a idéia de um mundo não mais dado, mas produzido: dominado, manipulado, inventariado e controlado: adquirido. (BAUDRILLARD, 1993, p. 34-35)

Para Baudrillard (1993), o objeto funcional é rico em funcionalidade e pobre em significação, refere-se à atualidade e se esgota na cotidianidade. Por isso é atualmente tido como tão "pobre", pois quaisquer que sejam suas qualidades, seus valores, seu prestígio, ele é e permanece configurativo da perda da imagem da tradição e de uma estabilidade. "O objeto funcional é a ausência do ser" (BAUDRILLARD, 1993, p. 89).

No cenário brasileiro não foi diferente. A origem do design brasileiro, salvo algumas exceções de determinados pioneiros ${ }^{4}$, teve um grande legado deixado pelo modelo racional-funcionalista, oriundo das influências estrangeiras trazidas principalmente pela Escola de Ulm, tanto no contexto educacional ${ }^{5}$ quanto na prática, firmando-se como a única e inabalável referência projetual para o design brasileiro por décadas. Segundo Moraes (2006, p. 63) "[...] o modelo racional-funcionalista vence e torna-se predominante como modelo único e de base para a instituição do design em praticamente todo o país.”.

\footnotetext{
${ }^{4}$ Moraes (2006) cita Joaquim Tenreiro, Zanine Caldas e Sergio Rodrigues no âmbito do produto industrial; Rubens Martins e Alexandre Wolner, no design gráfico; Aloísio Magalhães e Lina Bo Bardi representantes do design autóctone e popular.

${ }^{5}$ A ESDI - Escola Superior de Desenho Industrial, primeira faculdade oficial de design implantada no Brasil em 1964, tinha um programa baseado no currículo e estrutura programática da HfG - Ulm.
} 
Outra característica que podemos delegar à inicialização do design no Brasil é com relação à produção industrial. A indústria brasileira foi formada por modelos produtivos disseminados pelos países mais industrializados por décadas durante o século XX. Foi nesse período que se difundiram tecnologias e culturas de modelos comportamentais e de consumo de tais países. Para Moraes (2006), essa foi uma condição que em muito prejudicou o desenvolvimento e a autonomia do design no Brasil, "Isto é: eles funcionavam como verdadeiros exportadores de modus operandi, facendi e vivendi para grande parte do planeta" (MORAES, 2006, p. 41).

Assim, no Brasil, tanto o ensino quanto a prática e a produção foram, por muito tempo, guiados fortemente por influências estrangeiras, o que podemos considerar como um período que apresentou um "vácuo" no próprio pensar design no Brasil.

\section{Um novo olhar para o objeto}

Já em 2002, Manu profere outra palestra ${ }^{6}$ na qual disserta sobre a necessidade dos designers utilizarem ferramentas "lúdicas" como extensão da imaginação, em contraposição àquelas de procedimento racional-científico tão difundidas no design até então. Fala sobre o "design de captura dos sonhos" e a "estética da positividade", visando a projetos que provocassem sentimentos positivos aos indivíduos, proporcionando-lhes experiências boas e prazerosas.

Concordante com Manu, Kripenddorff (1996, p. 89) defende que as pessoas para as quais se projeta não são usuários meramente racionais e propõe que os designers devem ter em mente que seus produtos não são apenas "coisas" para suprir necessidades-padrões como defendia Le Corbusier, mas "práticas sociais, símbolos e preferências". Diz Kripenddorff: "Não reagimos às qualidades físicas das coisas, mas ao que elas significam para nós”. O autor afirma que a máxima de se projetar produtos estritamente funcionais para a produção em série se esgotou junto à Escola de Ulm, e que o design deveria ser centrado no ser humano e suas relações, não mais naquele que atendia o objeto e seus aspectos objetivos de produção e uso.

Outro importante autor dentro dessa argumentação é Jordan (2000), que advoga acerca da ideia de que os produtos também devem proporcionar experiências agradáveis a seus usuários, além das conhecidas eficiência e funcionalidade. Em Desmet (2002)

\footnotetext{
6 Palestra realizada em São Paulo, no Seminário Internacional de Design: Brasil/design/diversidade/negócios, promovida pelo SEBRAE em 2002.
} 
encontramos que as emoções enriquecem praticamente todas as nossas fases de vigília com momentos prazerosos ou não, e que parte dessas emoções advém das relações com produtos culturais, como arte, vestuário e consumo de produtos diversos.

Donald Norman em 1988 lança o livro The design of everyday things, no qual faz uma divertida análise da interferência do mau design na vida cotidiana. Já em 2004 em Emotional Design - why we love (or hate) everyday things diz que a função do designer ao projetar objetos de uso é que volte sua atenção para as pessoas e o modo como elas interpretam e interagem com o meio físico e social, e passem a projetar com foco na emoção e com a intenção de proporcionar experiências.

Já Hekkert (2006) diz que toda relação com um produto gera uma experiência ou um conjunto de efeitos no usuário. Assim, defende o autor, o processo de design pode ser gerido com o intuito de se promoverem experiências previamente definidas. Nesta tese defendemos o princípio de que o designer consegue induzir ou seduzir o usuário a algumas experiências, mas não totalmente defini-las. Mas este é um assunto que trataremos mais adiante.

Para o design, a ideia de que é possível desenhar formas capazes de proporcionar experiências prazerosas e despertar reações emocionais está ganhando força, do mesmo modo que a abordagem no desenvolvimento de projeto a partir do comportamento do usuário. O que antes era pautado pelo objeto autônomo e suas funções universais, hoje é norteado por uma relação contínua, dialógica entre o objeto e seus usuários.

Para Lucy Niemeyer (2008, p. 49), o ponto de partida é que a noção de significado é central no design: "O design trata da materialização de significados e emoções". Preferimos defender que não só trata da materialização de significados, como diz a autora, mas também de proposições materiais abertas às significações e às emoções. O designer projeta e consome diferentes produtos, desenha e contempla imagens, mas também, e principalmente, o designer experimenta, compreende e inventa um sem número de sentidos, emoções, significados, valores, ideias e desejos, e isso tudo, de uma maneira ou de outra, é convertido em produto.

Flusser (2010, p. 36) nos fala que o designer tem "uma espécie de olho parietal [...] que lhe permite perceber e relacionar-se com a eternidade". Para nós, esse olho parietal ao qual Flusser se refere é um "olhar" para as coisas que vai além de nos permitir apenas olhar, ele nos faz sentir e perceber, nos dando possibilidade de participar mais ativamente do mundo. 
Na relação do mobiliário com a habitação e a formação do lar, constata-se que a concepção formal dos produtos sempre foi pautada na evolução do espaço doméstico, do modo de morar e do surgimento do mobiliário como artefato de apoio às atividades, aos desejos e às aspirações humanas. Com qualquer outro objeto não foi diferente, nele ficaram impressos as necessidades, as expressões artísticas, o desenvolvimento da técnica e as relações simbólicas.

Podemos dizer que nas últimas décadas do século $\mathrm{XX}$, a importância que os significados de um objeto podem gerar ganha crescente relevância no desenvolvimento de projetos de design; cada vez mais os produtos exercem função determinante na constituição do homem, bem como em seu estilo de vida.

Um dos pontos fundamentais discutidos na contemporaneidade é a descoberta da particularidade do indivíduo, é a descoberta do eu: na experienciação direta e pessoal, na expressão das afetividades, nas emoções. Giddens (1990); Castells (2000) e Hall (2001) assinalam para uma crescente complexidade em todas as questões relacionadas à noção da cultura e à vida social e que essa estrutura faz parte da sociedade complexa (ou pós-tradicional). Dentro desse contexto, podemos apontar que os aspectos afetivos e emocionais são umas das questões a serem consideradas na tentativa de tratar com essa crescente complexidade.

Devemos entender que os afetos e as emoções não são simplesmente perturbações do pensamento racional, mas um recurso para orientação e conhecimento como qualquer pensamento racional e objetivo. Vincular as emoções e a experiência ao design pode ser considerado tanto uma reação à complexidade do ambiente pósindustrial, quanto um resultado dessa nova ordem. Assim, ao assumirmos a posição de "atores sociais", as nossas práticas sociais são vistas como reflexivas de uma situação conjuntural, segundo teorias sobre a modernidade tardia de Giddens (1990) ou da modernidade reflexiva de Beck (1997). Por conseguinte, ao fazer design, devemos desenvolver a capacidade de sermos ajustáveis e sensíveis às transformações dos interesses, tarefas, comunicações e, seguramente, afetos e emoções.

Niemeyer (2008) adverte que a preocupação atual de sugestões afetivas e emocionais no design parece indicar a vontade de reinserir as relações humanas no ambiente imediato. 
sistemas de comunicação parece ser o de reinserir os valores humanos e da sensibilidade humana no mundo material, para fazer nossas interações com os produtos menos impessoais e estritamente funcionais e mais relacionais, agradáveis e confiáveis. Os modos pelos quais se dá a avaliação de um produto dependem de fatores além da usabilidade, que estão atrelados a valores culturais e sociais e das condições na ocorrência de sua utilização. As variações de tempo, espaço e circunstância determinam especificidades dos critérios de avaliação da experiência vivida, acrescidos da particularidade de cada ser humano, peculiaridade essa crescentemente buscada na atualidade. (NIEMEYER, 2008, p. 51-52)

Seguindo o raciocínio de Niemeyer, podemos dizer que as qualidades simbólicas assumiram então papel determinante na apreciação de um produto, englobando experiências pessoais, sociais e culturais. Neste sentido, essas qualidades simbólicas evocam relações que são portadoras da identidade pessoal e social do usuário do produto. "Com elas [as relações], o ser humano reconstrói, a cada momento, a sua leitura de mundo e, em face dela, ele se situa, se localiza e é frente ao mundo" (NIEMEYER, 2008, p. 52, grifo nosso). Assim, entendemos que as experiências, as relações e as trocas simbólicas, sejam no nível individual ou coletivo, são de suma importância para o entendimento das relações afetiva e emocional entre o indivíduo e seu objeto.

Como abordado anteriormente, sabemos que tradicionalmente os produtos foram projetados com vistas às solicitações utilitárias e às possibilidades tecnológicas. Contudo, sabemos também que atualmente essa conduta não mais satisfaz. As funções utilitárias ou técnicas não atribuem, necessariamente, características de fato almejadas pelo usuário do projeto: "O que o produto 'diz' para o usuário e o que o usuário "fala" de si por meio dele" (NIEMEYER, 2008, p. 52). Fato que ilustra essa situação são os produtos da mídia digital e os ambientes das redes sociais, que se modificam no processo de interação com o usuário dependendo de suas expectativas, sentimentos e usos. São produtos que não cumprem mais um papel passivo e estável graças às possibilidades inovadoras das tecnologias. O que vemos atualmente são produtos que se adaptam às dinâmicas das relações de uso. Smartphones que possuem acesso à internet, às redes sociais, são câmeras fotográficas e filmadoras, relógio, agenda. Produtos que possuem uma infinidade de funções que podem ser acionadas a qualquer hora, em qualquer situação ou em qualquer lugar. Possuem ainda capas protetoras coloridas, com 
estampas e com formas de infinitas imagens que configuram todo um sistema de estar no mundo de seus usuários.

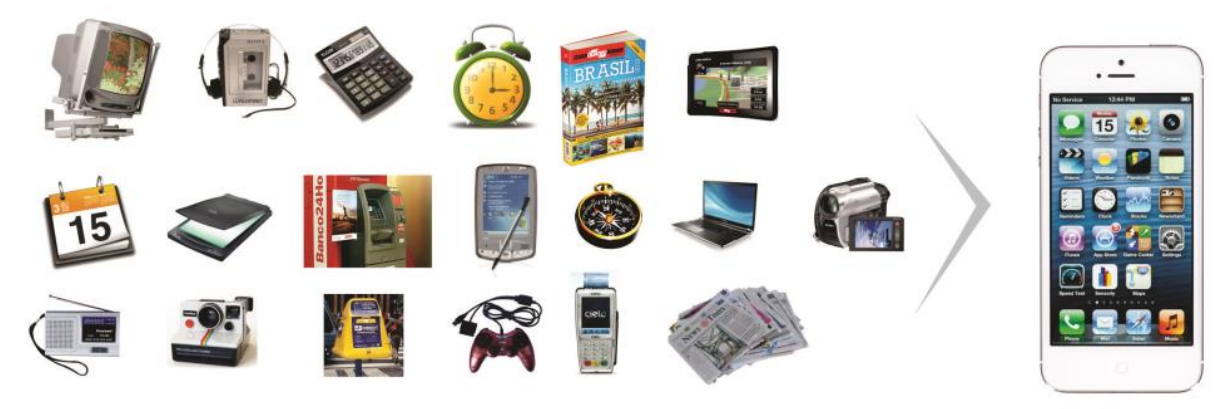

Figura 2 - Smartphones que contêm diversas funções e adaptam-se às dinâmicas das relações de uso

Niemeyer (2008, p. 53) destaca que fazer design é mais do que projetar produtos: "É resolver problemas de diálogo do ser humano com os outros e consigo mesmo". Podemos ir além e dizer que fazer design é unir, aproximar e "articular realidades" (BECCARI, 2012). Ao fazermos isso, estamos criando, recriando, interpretando, traduzindo, disseminando e dilatando realidades. Enquanto seres humanos que somos, lidamos com a nossa própria realidade subjetiva, e enquanto designers, lidamos com as realidades das outras pessoas e, nessa relação interpessoal, tanto a nossa realidade quanto a das outras pessoas adquire novos significados. Assim, ao fazermos nossa tradução das várias realidades, por meio de um objeto, estamos possibilitando às pessoas que vivenciem possíveis significações, experiências e emoções baseadas em suas próprias realidades.

Vimos ressaltando a necessidade de o designer estar atento às questões de significação do produto porque no design é fundamental que o produto seja capaz de emitir mensagens, e que os indivíduos possam ter a capacidade de assimilá-las. Assim, ao nos posicionarmos frente às realidades, estamos também articulando experiências, reações e emoções, e para isso, necessitamos de uma abordagem de projeto em que a interação com o produto vise à individualidade em construção num cenário complexo.

[...] o produto de design é tratado como portador de representações, participante de um processo de comunicação do destinatário consigo mesmo, com o produto, com os outros, por meio do produto. (NIEMEYER, 2008, p. 54) 
Interações do ser humano com o produto devem ser estudadas a fim de se entender as relações entre os aspectos físicos dos produtos e suas influências afetivas, com vistas a projetos que visem mais ao aspecto subjetivo do indivíduo e sejam significativos para ele. O que Niemeyer (2008, p. 55) propõe é o “design atitudinal [que tem como foco] a interação da eficiência com a significação, com as qualidades mais hedonistas dos produtos, em que as experiências positivas e prazerosas são fim em si mesmas."

Há controvérsias entre aqueles que estudam e debatem o design no sentido de que a discussão da relação afetiva e emocional entre as pessoas e seus objetos pode vir a ser mais uma proposta superficial, ou uma estratégia comercial para vender mais inutilidades e contribuir para uma sociedade de consumo efêmero. Queiroz (2011) em pesquisa sobre o sentimento de apego entre as pessoas e seus objetos, na qual utilizou notebooks como produto pesquisado, com características utilitárias e tecnológicas proeminentes, confirmou a premissa de que a construção do sentimento de apego ao produto é influenciada de modo significativo por reações emocionais, sejam elas advindas das novidades tecnológicas ou das relações estéticas e simbólicas.

Se os indivíduos gostam ou querem produtos que lhes deem prazer, então devemos pensar neles com características que sejam mais que funcionais ou utilitárias, devemos pensar o design como decorrência da união entre fatores próprios de uma nova proposta em que valores humanos sejam relevantes e que a emoção seja uma dimensão onde transcenda os tão arraigados ideais racionais da sociedade industrial.

Todas as relações humanas envolvem emoções, incluindo as interações com o mundo material. Essa interação é um dos modos pelos quais a individualidade se constrói e se exerce, dentro de um espectro de escolhas a que os indivíduos ou grupos têm acesso em determinado momento histórico de uma sociedade. As ações individuais, assim, encontram-se inseridas em um campo de possibilidades. Esses cenários sociais se compõem, também, de um acervo de produtos que se constituem elementos de expressão e de experimentação para o indivíduo. (NIEMEYER, 2008, p. 56)

Somos todos seres emocionais e essa característica afeta sobremaneira como percebemos o mundo. Em todas as relações com o meio, as emoções têm profunda ativação, e contribuem intensamente para a percepção, preferências e bem-estar. 
Sendo assim, defendemos o ponto de vista de que quanto maior for o grau de sensibilidade do designer frente às realidades e emoções do indivíduo, às questões do mundo e suas relações - e ele for suficientemente capaz de tratar essas questões -, mais existirá a possibilidade de serem desenvolvidos produtos que possam interagir com as pessoas de modo prazeroso e emocional.

Muito se tem estudado acerca de como as pessoas respondem emocionalmente aos produtos e quais aspectos do projeto provocam uma reação emocional. Alguns autores defendem que as emoções não são provocadas pelo produto em si mesmo, mas por significados dele derivados. Outros, seguindo uma abordagem fenomenológica, defendem que as emoções advêm do mundo percebido, antecedentes à reflexão, e que revelam o mundo vivido antes de ser significado.

Admitimos que ambas as partes têm suas razões. Em alguns casos, como placas de sinalização, advertência ou produtos que exijam altos níveis de segurança ao serem manuseados, o significado tem de vir obrigatoriamente no instante de leitura ou interação com o produto, não possibilitando possíveis significações, como as cores vermelha, amarela e verde em um sinal de trânsito, ou uma tarja preta numa embalagem de medicamento. Já em outros casos, a relação entre os objetos e os indivíduos acontece de maneira que os processos de reflexão reconhecem na percepção do mundo dado o seu fundamento, e é por meio dos sentidos que ele se manifesta para reflexão, como o sentir a água morna de um banho, ou o relaxamento do corpo ao se sentar em uma poltrona confortável. Dessa maneira, não há diferença entre pensar e perceber, que devem ser concomitantes e interpenetrantes.

Assim, as emoções podem decorrer dos atributos tangíveis do produto, dos construtos altamente pessoais do usuário ou dos fenômenos que contêm uma essência que nos faz pensar no objeto de acordo com a maneira como ele nos foi dado à consciência.

Tomemos como exemplo a Poltrona Mole, de Sergio Rodrigues. 


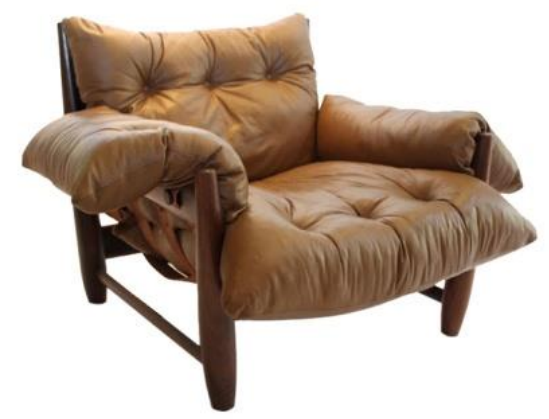

Figura 3 - Poltrona Mole, Sergio Rodrigues, 1957

Ao nos depararmos com um objeto como este, seguramente algumas relações surgirão, concomitantemente ou não:

- o tipo de madeira e suas formas robustamente torneadas, o couro que reveste grandes almofadões, as formas extravagantes e soltas, e as dimensões demasiadamente avantajadas nos remetem, enquanto atributos tangíveis, a relações bem determinadas e identificadoras enquanto um produto de características informais;

- ao sentarmos na Poltrona Mole, nos deparamos não com uma "poltrona", como aquelas que exigem postura, nobreza. $\mathrm{O}$ indivíduo se perde dentro dela, se refestela. $\mathrm{O}$ uso propõe uma infinita gama de possibilidades de descobrimentos e entendimentos que dependem exclusivamente dos construtos pessoais e do imaginário do indivíduo;

- ou, por fim, ao nos esparramarmos e nos refestelarmos, nos sentimos também acarinhados e relaxados, nos levando às relações intuitivas e emocionais tal qual estes fenômenos (relaxar, acarinhar, abraçar) se apresentam à nossa experiência.

Como dissemos no início deste capítulo, consideramos o designer como aquele que une, aproxima e articula realidades e, ao fazer isso, não o faz unicamente a partir de sua subjetividade, mas da sua e das outras pessoas, devendo preocupar-se em manter um "sentido aberto" para que aconteçam outras significações e vivências.

Ao analisarmos o universo dos objetos pelos quais o design é responsável, nos deparamos com uma infinidade de produtos em que os usuários têm dificuldade ao manipulá-los. É uma interface de uma página de banco em que não encontramos o link home ou "voltar"; um descascador de batatas que não descasca as batatas e sim os 
nossos dedos; ou uma embalagem plástica de biscoitos que ao ser aberta lança-os ao ar como se estivéssemos numa competição de cata-biscoito. O nosso cotidiano material deveria residir no mundo vivido, permitir que os objetos tivessem "gestos" ou acenassem de maneira que, na relação homem versus mundo construído, os objetos possuíssem "sinais naturais, interpretados naturalmente, sem nenhuma necessidade de se estar conscientes deles" (NORMAN, 2006, p. 28).

Numa análise fenomenológica, Norman trabalha com o conceito de affordances, ${ }^{7}$ que resumidamente, seriam "sinais" que o material do objeto ou um objeto em si emitiriam ao usuário, que, por sua vez, se relacionaria com eles por meio de sua percepção e de seus sentidos. Para o autor, grande parte das informações que uma pessoa precisa para realizar uma tarefa está no mundo, “o comportamento é determinado pela combinação das informações na memória (cabeça) com as que se encontram no mundo" (NORMAN, 2006, p. 82).

Flusser (2007, p. 197) diz que a humanidade por anos produziu objetos de uso cada vez mais úteis, sem atentar aos aspectos intersubjetivos e comunicativos, e que o "progresso científico e técnico é tão atrativo que qualquer ato criativo ou design concebido com responsabilidade é visto praticamente como retrocesso." O que Flusser categoriza como "responsabilidade", entendemos "estar preocupado com o outro", ou seja, quando assumimos a responsabilidade de criar objetos devemos enfatizar os aspectos intersubjetivos e os valores humanos.

No caso dos objetos de uso, topo com projetos e designs de outros homens. (Quando se trata de outros objetos, topo com algo diferente, talvez absolutamente Outro). Objetos de uso são, portanto, mediações (media) entre mim e outros homens, e não meros objetos. São não apenas objetivos como também intersubjetivos, não apenas problemáticos, mas dialógicos (FLUSSER, 2007, p. 195).

Podemos notar nessa passagem de Flusser (2007), ou nos argumentos de Norman (2006) e de Niemeyer (2008), que todos têm um ponto em comum e concordante com nosso pensamento: designers devem criar objetos que possibilitem a

7 “As affordances do meio ambiente são o que ele oferece para o animal, aquilo que o ambiente fornece ou de que dispõe, seja para o bem, seja para o mal. O verbo afford (dispor) encontra-se em dicionários, mas o substantivo não. Eu o inventei. Por meio dele quero dizer algo que se refere ao mesmo tempo ao ambiente e ao animal, de uma forma que nenhum termo existente o faz. Implica a complementaridade do animal e do ambiente..." GIBSON, James. The ecological approach to visual perception. [S.l.]: [S.n.], 1979, p. 127. 
manifestação das realidades objetiva, subjetiva e intersubjetiva e, ao mesmo tempo, permitir o exercício da experimentação e identidade individual, que, expressas e atualizadas, fazem que o ser se articule de modo mais sensível com a sua cultura material.

Para tanto nos surgem questões a serem discutidas e respondidas: o que de fato são emoções? Como um produto pode suscitar reações emocionais nos indivíduos? Quais são os aspectos emocionais que se destacam em uma situação de relação com o produto?

Antes de levarmos adiante tais questionamentos, é prudente observarmos alguns pontos:

- emoções são individuais, pessoais e nesse sentido, as pessoas podem apresentar diferentes respostas a um mesmo produto;

- os produtos, em sua maioria, não evocam um único tipo de emoção; levam a uma gama de emoções.

A priori apresentaremos duas definições de emoção para melhor situarmos o termo no conteúdo já apresentado e darmos continuidade à nossa argumentação. Contudo, explanaremos e discutiremos detalhadamente os conceitos de emoção, assim como outras acepções que se fazem necessárias e que são relativas ao assunto em um tópico mais à frente (ver item 1.1).

Antonio Damásio, neurocientista, define emoção como sendo

[...] a combinação de um processo avaliatório mental, simples ou complexo, com respostas dispositivas a esse processo, em sua maioria dirigidas ao corpo propriamente dito, resultando num estado emocional do corpo, mas também dirigidas ao próprio cérebro [...] resultando em alterações mentais adicionais (DAMÁSIO, 2006, p. 168-169).

Para Norman (2008, p. 35), as emoções trabalham por meio de "substâncias químicas neuroativas que penetram determinados centros cerebrais" e modificam a percepção, o comportamento e os parâmetros de pensamento. Para ele, as emoções e a cognição são inseparáveis e fazem parte da formulação de um "juízo de valor que nos permite sobreviver melhor". Damásio e Norman confirmam que a emoção advém de um processo cerebral, e Damásio complementa que ela é o resultado de alterações nos estados do corpo. 
A emoção, então, pode ser entendida como um mecanismo utilizado para atribuição de julgamentos aos estímulos internos (indivíduo) e externos (meio ambiente).

A partir de estudos sobre emoção, Norman (2008) sugere que somos resultado de três níveis de estruturas do cérebro: o nível visceral (automático, pré-programado, pré-consciente, anterior ao pensamento); o nível comportamental (aquele que controla a maior parte de nossas ações, contudo pode não ser consciente) e o nível reflexivo (que se refere à interpretação, compreensão e raciocínio e à parte contemplativa do cérebro). Para o autor, esses três níveis de estrutura cerebral operam entrelaçados e são identificados em nossa relação com os objetos, podendo ser mapeados em termos de características de produto (NORMAN, 2008, p. 14).

Assim, faz as analogias: 1) design visceral; 2) design comportamental; e 3) design reflexivo.

O design visceral é aquele que se refere aos aspectos físicos e ao primeiro impacto causado por um produto, "é o que a natureza faz" (NORMAN, 2008, p. 87). Diz respeito às primeiras impressões, à aparência do produto, toque, sensação. É nesse nível que acontecem todas as manifestações biológicas. Os seres humanos têm tendência a selecionar "coisas" que lhes atraem no sentido do instinto de sobrevivência e que lhes deem prazer positivo. É fato que a cultura determina um papel preponderante nessa situação, mas segundo o autor, ainda assim

[...] algumas culturas preferem pessoas gordas, outras, magras; mas até no seio dessas culturas existe uma concordância sobre o que é ou não atraente, mesmo se magro ou gordo demais agradar a gostos específicos. (NORMAN, 2008, p. 88)

Segundo o autor, os seres humanos gostam de explorar experiências além daquelas biologicamente predeterminadas. Assim, embora o frio da neve intensa seja visceralmente temível, as pessoas aprenderam a viver em ambientes gelados e até mesmo a preferi-los. Nesse sentido, surge o "gosto adquirido", que sugere que as pessoas tiveram de aprender a ultrapassar as suas inclinações naturais (biológicas). Assim, o autor fala que as coisas que em princípio são visceralmente negativas, podem culturalmente se tornar reflexivamente positivas. São nessas situações que podemos encontrar o paradoxo existente entre o design visceral e reflexivo: "os princípios 
subjacentes do design visceral são predeterminados, consistentes entre povos e culturas" (NORMAN, 2008, p. 87).

Um exemplo corriqueiro acerca da relação visceral e reflexiva são alguns modelos de sapatos femininos com salto alto e bico fino, que se fossem submetidos a testes ergonômicos, de uso ou segurança, certamente seriam reprovados. Contudo, há um dado peculiar e importante junto às usuárias deste produto. Para elas, tais sapatos não são considerados um produto para proteger os pés, tampouco um auxílio para caminhar, eles são uma construção social, em que aspectos emocionais e simbólicos sobressaem a qualquer risco ou desconforto físico. ${ }^{8}$

Como o nível visceral diz respeito às reações iniciais, para o design é importante questões como textura, peso, dimensões, tudo que é ligado às sensações físicas. No design visceral tudo que é relacionado ao impacto emocional imediato é significativo.

O design comportamental diz respeito ao uso dos objetos. Aqui, nem aparência, tampouco o raciocínio lógico, importam. O que importa é o desempenho. Na maioria dos casos, o que vem em primeiro lugar é a função do produto. Segundo Norman (2006) os quatro componentes do bom design comportamental são função, compreensibilidade, usabilidade e a sensação física. Para que um produto se enquadre nessa categoria, o primeiro requisito pelo qual ele deverá passar é o de satisfazer necessidades. $\mathrm{O}$ autor explica que não é tão fácil como parece satisfazer o critério função, pois as necessidades das pessoas não são óbvias como parecem.

Sabemos que, normalmente, no procedimento de desenvolvimento de produtos existem dois caminhos: o aperfeiçoamento e/ou inovação. O aperfeiçoamento significa melhorar um produto ou serviço existente a partir de avaliações e proposições anteriormente definidas. $\mathrm{Na}$ inovação não existem procedimentos específicos que podem servir de base. "A inovação oferece uma forma completamente nova de fazer alguma coisa, ou uma coisa completamente nova para fazer, algo que antes era impossível" (NORMAN, 2008, p. 93). Sendo assim, para que a inovação se torne apta a ser aprovada pelo design comportamental, é necessário compreender as necessidades dos usuários ainda não manifestadas e que não estão sendo atendidas.

Para tanto, o autor coloca que a única maneira de se descobrir tais necessidades é fazendo observações cuidadosas no ambiente natural dos usuários. As tecnologias dos

\footnotetext{
${ }^{8}$ Para mais esclarecimentos sobre esse tema, consultar VAN der LINDEN, Júlio. Ergonomia e design: prazer, conforto e risco no uso de produtos. Porto Alegre: UniRitter Ed., 2007.
} 
Smartphones, tão difundidas e utilizadas atualmente, são um grande exemplo de inovação junto ao design comportamental.

"Depois da função vem a compreensão" (NORMAN, 2008, p. 97). Com uma boa compreensão, uma vez que a operação é explicada e se torna clara, as pessoas apreendem o uso. Segundo o autor, um componente importante da compreensão é o feedback de informações. É por ele que temos o retorno de quando um equipamento está funcionando: a sensação do pedal do freio de um carro quando é apertado e o carro reduz a velocidade; o som do botão ao ser ativado; o acionamento luminoso de um menu de uma interface gráfica; ou um simples sentar em uma poltrona e sentir o relaxamento do corpo. É no design comportamental que as emoções positivas ou negativas aparecem. Se os usuários têm um bom feedback de suas ações, as emoções são positivas; se elas se sentem frustradas ou fora do controle de compreensão no uso, as emoções negativas surgem.

No design reflexivo estão as particularidades individuais e culturais dos usuários. Significados e memória afetiva são atribuídos aos produtos e ao seu uso. É uma categoria que lida com os aspectos subjetivos.

Design reflexivo cobre um território muito vasto. Tudo nele diz respeito à mensagem, tudo diz respeito à cultura, tudo diz respeito ao significado de um produto ou seu uso. Por um lado, diz respeito ao significado das coisas, às lembranças pessoais que alguma coisa evoca. Por outro, diz respeito à auto-imagem e às mensagens que um produto envia às outras pessoas. (NORMAN, 2008, p. 97).

Norman exemplifica o design reflexivo por meio dos relógios Swatch. Diz que a empresa transformou a indústria de fabricação de relógios. De fabricantes de relógios transformaram-se em fabricantes de emoção. Da função de marcar a hora, para a função de emocionar. Um conceito de produto de alta tecnologia transformado em um veículo para emoções.

No Brasil temos também infinitos exemplos de como as empresas estão sensíveis a esse novo espírito. Em 2009, o grupo Pão de Açúcar alterou sua identidade visual e tomou como tema "felicidade", emoção destacada em pesquisas qualitativas junto aos seus clientes. Assim, para realçar este valor o grupo aproveitou a oportunidade para chamar a atenção de seus clientes para a preocupação com o indivíduo, com a sociedade e com o mundo em que vivemos. A campanha publicitária apresenta as perguntas “O que faz você feliz?”; “Quer fazer você feliz?”; “Quer fazer alguém feliz?”; 
"Quer fazer o planeta feliz?"; e sugere práticas para melhorar a qualidade de vida pessoal, da comunidade e do planeta. A marca tem como lema: "Pão de Açúcar, lugar de gente feliz".

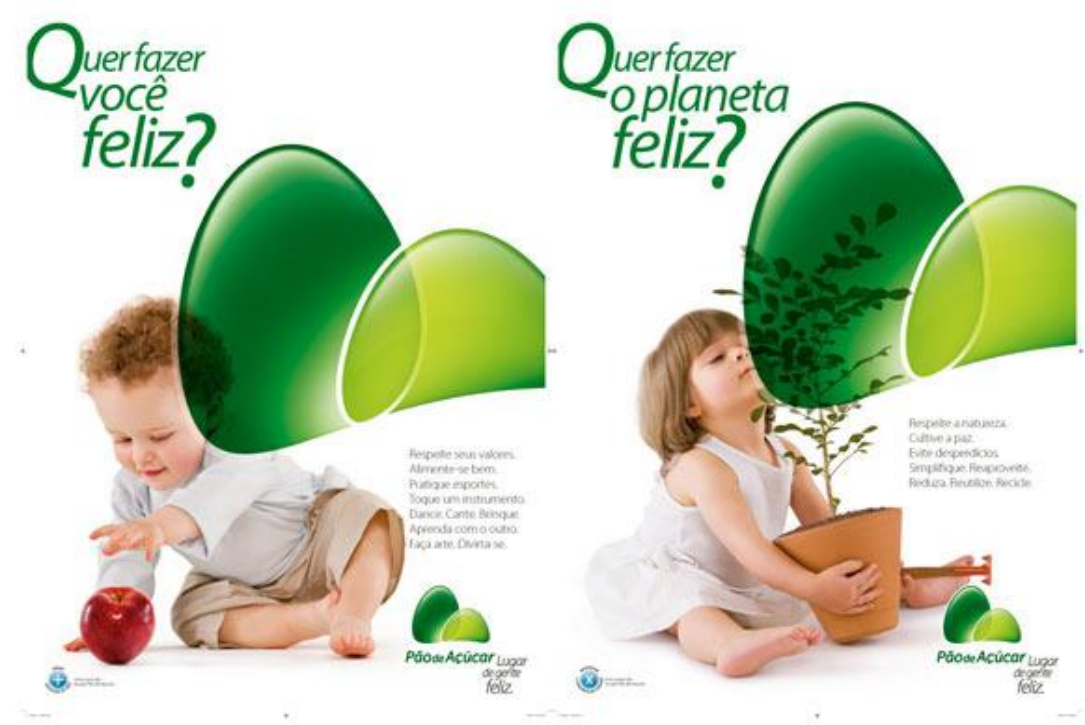

Figura 4 - Peças da campanha publicitária para a apresentação do novo logotipo do Grupo Pão de Açúcar, nas quais a emoção "felicidade" é salientada

No design reflexivo, os produtos são mais do que a soma das funções que desempenham. Uma das suas atribuições é a de satisfazer as necessidades emocionais das pessoas, e uma das mais importantes é a de demonstrar o lugar que o indivíduo ocupa no mundo, a sua autoimagem.

Para tanto, é um design que pode ser considerado subjetivo e/ou cultural. Música dissonante pode ser bonita. Objetos que não são atraentes na superfície podem dar prazer ao serem usados. O que consideramos bonito, feio, bom ou ruim vem da reflexão consciente e da experiência e isso é influenciado pelo conhecimento, pelo aprendizado e pela cultura. 


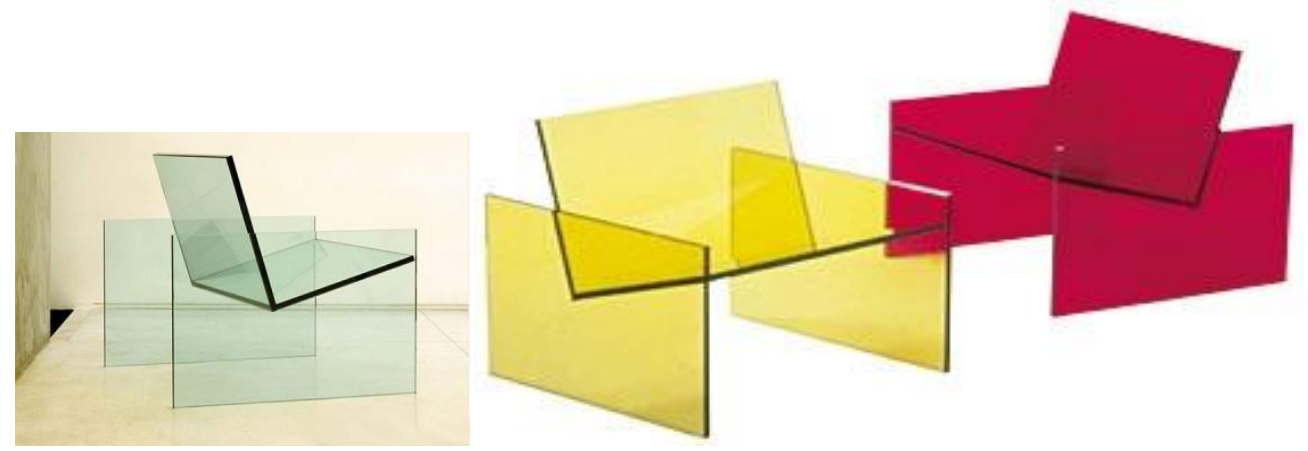

Figura 5 - Poltrona Quatro, de Jaqueline Terpins, 1999

A figura 5 ilustra o conjunto de poltronas Quatro, produzidas em placas de vidro laminado unidas por cola. Essas poltronas pesam cerca de $230 \mathrm{~kg}$ cada, no entanto transmitem uma sensação de leveza e translucidez devido ao uso do vidro. Certamente o material nos dá essa impressão global que atenua e disfarça o seu real peso. Entretanto, por ser uma poltrona, nos causa uma percepção de estranhamento. Um estranhamento em dois sentidos: o primeiro diz respeito ao objeto que traduz algo que desaparece em sua superfície, revelando-se em um objeto sem "gravidade", fazendo-nos sentar no ar. O segundo estranhamento, e o que vem depois de revelado o entendimento acerca do material, é o de se sentar sobre o vidro e em uma estrutura sem "sinais" de uma construção sólida, com encaixes ou uniões aparentemente rígidas: são apenas placas de vidro coladas umas às outras. Sentimento de fragilidade, de medo e de dor. O que nos vem à cabeça é uma realidade de receio e temor de que, ao se sentar, aquilo irá se desmantelar e estilhaçar.

É nesse sentido que as operações no nível reflexivo frequentemente determinam a impressão global que uma pessoa tem de um produto. É o momento em que as deficiências de um aspecto específico podem ser superadas pelos pontos fortes de outro: ao recordar o objeto, o usuário reflete suas impressões globais, seus apelos totais e a experiência de usá-lo. "O impacto global de um produto vem através da reflexão - na memória retrospectiva e reavaliação" (NORMAN, 2008, p. 111).

O poder do design reflexivo está, na realidade, baseado na experiência de longo prazo do usuário.

Assim, as categorias de design de Norman (2008) - visceral, comportamental, reflexivo - nos levam a refletir como as relações entre indivíduo e objeto podem ser 
desenvolvidas, bem como nos auxiliam a detectar em quais níveis de interação os processos emocionais acontecem e como acontecem, como demonstra a figura 6:

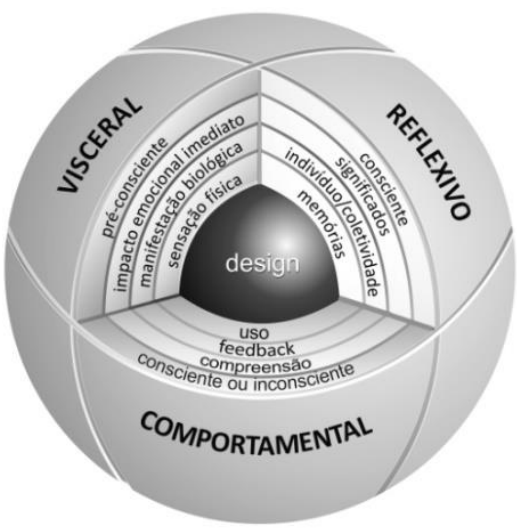

Figura 6 - Representação das categorias do design segundo estudos da emoção, Norman (2008). Adaptado pela autora

Portanto, podemos dizer que os objetos levam a respostas emocionais. Essas emoções influenciam tanto a decisão de compra quanto o prazer de possuir e usá-los. Assim, além de estabelecerem relações no nível objetivo e serem usáveis/manipuláveis, os objetos instituem uma relação em nível subjetivo com o indivíduo. Desse modo, consideramos fortemente a proposta de que os objetos possibilitem induzir ou suscitar reações aos indivíduos (emoções, sentimentos, afetos) que eles gostariam de experimentar ou de experienciar.

\subsection{Sobre Emoções}

Para melhor elucidar as considerações já apresentadas, e que ainda serão discutidas, achamos por bem delimitar nossa abrangência sob a perspectiva de algumas definições e conceitos.

Neste tópico discutiremos acerca de questões como afeto, emoção, sentimento, sentidos, sensações, percepção e experiência. Os seis primeiros terão como base as teorias da psicologia cognitiva e da neurociência, para entendermos melhor seus mecanismos e processos. Já a experiência, para mais bem integrarmos tais conceitos à nossa realidade, será analisada sob a perspectiva do design. 
Person (2003), com base em pesquisas realizadas por Randolph Cornelius, que analisou as diferentes correntes teóricas contemporâneas sobre emoção, apresenta as ideias centrais da pesquisa e as categoriza em quatro perspectivas: Darwiniana, Jamesiana, Cognitiva e Sociocultural (PERSON, apud VAN der LINDEN, 2007).

Apresentaremos abaixo os principais pontos a respeito das categorias.

a. Darwiniana - tem como conceito principal o de que as emoções oriundam de mecanismos evolutivos, nos quais as emoções se desenvolveram como respostas a certos problemas que afetaram e transformaram a evolução das espécies. Seguindo as teorias de Darwin, defende que as emoções são inatas e suas expressões são universais e calcadas em respostas primitivas.

b. Jamesiana - advinda das pesquisas de Willian James, as emoções são reações a mudanças corporais. Propõe duas questões básicas: a primeira é a de que as emoções acontecem como resultado de respostas automáticas que o corpo desenvolveu para adaptar-se ao ambiente; a segunda diz que elas formam a experiência das alterações que o corpo sofre ao responder às necessidades de sobrevivência.

c. Cognitiva - parte do princípio de que pensamento e emoção são inseparáveis. As emoções advêm das avaliações do quanto os eventos no ambiente (isso incluiu pessoas e objetos) são positivos ou não para o indivíduo. Oriundas de processos de juízos, as emoções positivas são provenientes de estímulos benéficos; as negativas, de estímulos avaliados como nocivos. Apesar de haver um processo de juízo acoplado às emoções, a perspectiva cognitivista defende o princípio de que a avaliação é não deliberada, não reflexiva, não intelectual, mas automática, imediata e direta. Nessa abordagem, as emoções estão associadas a um tipo de avaliação que está diretamente vinculado às características individuais das pessoas e às características da situação com a qual o indivíduo se defronta.

d. Socioconstrutivista - para essa corrente, as emoções são fruto da cultura, dependentes de convenções e regras sociais. Defende que as pessoas avaliam seu ambiente por determinação cultural. Teóricos dessa perspectiva dizem que o processo de avaliação das emoções pode vir de adaptações biológicas, porém o conteúdo dessa avaliação é cultural. 


\begin{tabular}{ll}
\hline TEORIA & EMOÇÕES \\
\hline Darwiniana & Adaptativas e universais \\
Jamesiana & Respostas corporais \\
Cognitiva & Baseadas em ativações \\
Socioconstrutivista & Construções sociais \\
\hline
\end{tabular}

Figura 7 - Perspectivas sobre emoções,
Person (2003). Adaptado pela autora

Ao analisarmos as proposições acima, podemos tirar algumas conclusões no que diz respeito às suas concordâncias e discordâncias. A primeira delas é entre o ponto de vista das perspectivas Darwiniana e Jamesiana, defensoras de que as emoções são universais e instintivas, e a perspectiva Socioconstrutivista, que recusa essa hipótese e propõe que as emoções são oriundas de convenções culturais e sociais. Já na abordagem cognitivista, há a impressão de que as emoções são intelectualizadas, pois participam de um processo de juízo. Os teóricos, contudo, negam essa suposição e afirmam que a avaliação das emoções é processo automático e imediato.

Para a nossa abordagem, utilizaremos uma mescla de conceitos cognitivistas e socioconstrutivistas, pois cremos que essas propostas nos auxiliarão a entender como a emoção se manifesta na relação corpo/mente e objeto de maneira objetiva, já que tratamos de objetos físicos, tangíveis. Também entendemos que é a partir dessas perspectivas que poderemos discutir de que modo o subjetivo e o intersubjetivo acontecem, do ponto de vista do design. A partir das proposições do neurocientista António Damásio e do psiquiatra Daniel Siegel, que serão enriquecidas por outros autores, apresentamos uma coletânea de pensamentos acerca da experiência emocional.

\section{a) Corpo e mente}

A separação do corpo e da mente é uma proposta filosófica que tomou grandes proporções e tem sua força na teoria de René Descartes, no século XVII.

Descartes postulou duas questões distintas: a substância espacial (matéria/corpo) e a substância pensante (mente). Assim, aponta o dualismo, ou seja, a ideia de que mente e corpo são entidades distintas. Ele acreditava que as coisas deveriam ser explicadas por uma redução aos seus elementos e, em última análise, aos seus elementos irredutíveis. O sujeito individual foi colocado no centro da "mente", formado por sua 
capacidade de raciocinar e pensar. "Penso, logo existo"- esse era o axioma. Desse modo, o sujeito cartesiano é conhecido como o sujeito racional, pensante e consciente, situado no centro do conhecimento.

Atualmente qualquer tipo de dualismo que siga essas prerrogativas é questionado e repelido por alguns setores da filosofia, psicologia e ciência cognitiva.

Uma das críticas ao dualismo cartesiano é encontrada no pensamento de António Damásio 9 que questiona a dicotomia entre mente e corpo. Em seu livro "O erro de Descartes: emoção, razão e o cérebro humano" (2006), o autor coloca que essas duas entidades são inseparáveis e estão integradas por circuitos bioquímicos e neurais mútuos, e é através dos nervos e do sangue que esse processo acontece. Para tanto, interagindo corpo e mente mutuamente, instituem uma "composição" que age de forma também intensa com o meio que o cerca. Para o autor, a sobrevivência está sempre sendo buscada (consciente ou inconsciente) e depende de uma condição favorável. Sendo assim, Damásio (2000) defende que não se pode separar o corpo da mente, a emoção da consciência: o corpo é o lugar das emoções e a mente, a casa da consciência, sendo que corpo e mente caminham juntos em prol da conservação da espécie humana.

Segundo Damásio (2006), os acontecimentos no corpo são mediados pelos aparelhos sensoriais e pelo movimento do organismo. São os sentidos que participam ao homem o seu estar no mundo, e é no cérebro que essas informações são construídas e processadas de diversas maneiras.

Isso, para o design, significa que, ao serem manipulados ou experienciados, os objetos - aqueles que estimulam - são responsáveis por uma construção interna nos indivíduos, e é nessa construção interna que são desencadeados os processos emocionais.

Podemos fazer uma correlação entre a assertiva de Damásio junto aos níveis de processamento de informações propostos por Norman (2008). Como já elucidado anteriormente, o autor propõe três níveis de processamento de informação: o nível visceral, automático; o nível comportamental, que coordena a atividade diária; e o nível reflexivo, contemplativo, que opera a avaliação do pensamento consciente e a memória.

Na concepção de Norman, os níveis visceral e comportamental são informados de maneira direta pelos sentidos, via aparelhos sensoriais, ao passo que o nível

\footnotetext{
${ }^{9}$ António Damásio, reconhecido neurocientista, foi um dos pioneiros na investigação acerca das relações entre razão e sentimentos, emoções e comportamento social. Sua visão considerada inovadora propõe que sentimentos e emoções são uma percepção direta de nossos estados corporais e constituem um elo essencial entre o corpo e a consciência.
} 
reflexivo, por meio da mente, controla a situação. Esses três níveis atuam reciprocamente e é dessa interação que surgem as reações particulares de cada indivíduo.

Na perspectiva desses autores, o corpo sofre a experiência e envia ao cérebro, que por sua vez monta as imagens daquilo que acontece. Por outro lado, as memórias já construídas pelas experiências anteriores serão combinadas com essas novas imagens repassadas ao cérebro. Para esses autores, é da condição humana estar envolto na produção de imagens. No exemplo da figura 5, as poltronas Quatro de Jaqueline Terpins, fica clara a construção de imagens de estranhamento com relação ao material "inusitado" utilizado para a estrutura do objeto.

Segundo Azevedo (2003), a memória é um processo de retenção e resgate de experiências vividas, e para Izquierdo (2002), ela consiste na aquisição, na gravação, na conservação e na evocação de informações. O pensamento criativo, enraizado no imaginário, é a tradução da combinação dessas informações conscientes ou inconscientes. Já o imaginário se constitui como o domínio da imaginação, entendida como capacidade criativa, produtora de imagens subjetivas (interiores) que podem ser exteriorizáveis (ALMOUNT, 1993). Para tanto, podemos dizer que as imagens são frutos do imaginário e a imaginação é a habilidade de procurar no imaginário as formas que serão conformadas como imagens. Seguindo esse raciocínio, Hillman (1995, p. 28) assegura que as imagens não são aquilo que se vê, mas a "maneira como se vê".

Assim, tanto nos processos de design (projeto e criação pelo designer) quanto nos processos de interação do indivíduo com os objetos, as emoções suscitadas são construídas a partir de ajustes entre as imagens interiores e exteriores. Por processos subjetivos e intersubjetivos, nos quais o nosso "olhar parietal" nos permite olhar, perceber e sentir.

\section{b) Afeto, emoções e sentimentos}

Para LeDoux (2001) e Strongman (2003), a emoção é um fator fundamental para processos cognitivos, tais como a memória, a tomada de decisão e a resolução de problemas. As dimensões cognitivas e afetivas estão em tudo o que praticamos, realizamos e vivemos. Segundo Norman (2008), o componente cognitivo atribui significado às nossas experiências, e o componente afetivo atribui valor. 
Nesse sentido, afeto pode ser entendido como um conjunto de reações físicas, involuntárias e, portanto, desprovidas de conteúdo intelectual. Afeto é aquilo que nos "afeta" de alguma maneira; são reações inconscientes. Já as emoções são entendidas como a "conscientização" do afeto, e os sentimentos como construtos mais duradouros, que incluem respostas estéticas e intelectuais e são aprendidos, segundo Aboulafia e Bannon (2004); Khalid (2006); Khalid e Helánder (2006). Para o design, isso significa que, ao usarmos ou manipularmos um objeto, passamos por processos inconscientes e conscientes, subjetivos e objetivos, e imagens serão construídas. Isso quer dizer que quanto mais o objeto nos "afetar" (positivamente ou não) por meio de sua estrutura física, por meio da sua forma, ou de seus significados, mais serão gerados emoções e sentimentos com relação a ele.

É exatamente este, o ponto defendido aqui. Numa época em que o cenário que se constitui no mundo é cada vez mais complexo e repleto de relações interdisciplinares e interpessoais, objetos nulos, mudos e silenciosos não têm mais um destino pela frente. Os objetos têm de falar, têm de nos olhar e serem olhados. Têm de permitir um diálogo entre ele e quem o manipula, numa relação dialógica na qual haja um processo fértil e favorável a uma "elasticidade" entre elementos díspares que possibilitem ascender a novas relações.

Como já mencionado anteriormente, as emoções são o resultado de mudanças nos estados do próprio corpo. Elas estão unidas no trabalho cerebral de estabelecer respostas eficientes aos eventos que ocorrem no ambiente.

A partir da perspectiva Darwiniana, Christianson (1992) diz que as emoções básicas são universais, de base biológica, inerentes ao ser humano. Desde a infância se associam ações primitivas e expressões faciais. Já para Siegel (2004), ao se falar das emoções é necessário pensar na mente individual (subjetiva) imersa no contexto das relações humanas e dependentes de convenções e regras sociais. Para esse autor, as emoções são processos dinâmicos criados junto às ações de apreciação de valores, os quais são socialmente influenciados e influenciadores, seguindo assim a proposta Socioconstrutivista.

Para Damásio (2000), as emoções são produzidas por mecanismos localizados nas regiões subcorticais do cérebro e utilizam o corpo para se projetar. Nesse sentido, há de se entender que as emoções podem alterar tanto o corpo quanto a mente, transformando-os em um organismo uno. 
Sentimentos e emoções formam um elo entre a natureza e as circunstâncias: “[...] emoções e sentimentos são sensores para o encontro, ou falta dele, entre a natureza e as circunstâncias". Por natureza, o autor se refere como aquilo que "herdamos enquanto conjunto de adaptações geneticamente estabelecidas" e também o que se adquire "por via do desenvolvimento individual através de interações com o ambiente social, quer de forma consciente e voluntária, quer de forma inconsciente e involuntária” (DAMÁSIO, 2006, p. 15).

Cada experiência da nossa vida é acompanhada por algum grau de evolução, por menor que seja, e esse fato é especialmente notável em relação a problemas sociais importantes. Quer a emoção responda a um estímulo escolhido pela evolução, como acontece no caso da simpatia, ou a um estímulo aprendido individualmente, como acontece no medo que podemos ter adquirido em relação a certo objeto em conseqüência de o termos associado a um estímulo de medo primário, o fato é que as emoções, positivas ou negativas, bem como os sentimentos que se lhes seguem, tornam-se componentes obrigatórios de nossas experiências sociais (DAMÁSIO, 2004, p. 156-157).

Os sentimentos e as emoções são como condutos para uma resposta corpórea: independentemente de nossa vontade, nosso organismo se envolve com os sentimentos e responde a estímulos, sendo assim, projeta uma resposta compreendida e assimilada de forma positiva ou negativa por todo o organismo.

[...] emoção é a combinação de um processo avaliatório mental, simples ou complexo, com respostas dispositivas a esse processo, em sua maioria dirigidas ao corpo propriamente dito, resultando num estado emocional do corpo, mas também dirigidas ao próprio cérebro [...] resultando em alterações mentais adicionais (DAMÁSIO, 2006, p. 168-169).

Nesse sentido, sentimentos e emoções manifestam-se fisicamente no corpo e são eles que nos mantêm conectados ao meio que nos cerca e nos permitem entrar em contato com a natureza. Aqui, nesse caso, os objetos artificiais, bem como aqueles produzidos pelo design, fazem parte do meio, do entorno projetado, e influenciam a natureza.

[...] o amor, o ódio e a angústia, as qualidades de bondade e crueldade, a solução planificada de um problema científico ou a criação de um 
novo artefato, todos eles têm por base os acontecimentos neurais que ocorrem dentro de um cérebro, desde que esse cérebro tenha estado e esteja nesse momento interagindo com seu corpo. A alma respira por meio do corpo, e o sofrimento, quer comece no corpo ou na imagem mental, acontece na carne (DAMÁSIO, 2006, p. 18).

Damásio apresenta duas classificações com relação às emoções. Em "O erro de Descartes" (2006) diz que as emoções dividem-se em duas categorias: as primárias, aquelas que sentimos quando crianças, de caráter natural, cognitivo e sinestésico; as secundárias, que serão vivenciadas após termos passado pelas primárias. O que nos importa nas emoções secundárias é que elas se relacionam ao universo particular de cada indivíduo (nível subjetivo) e são criadas a partir de experiências que foram vivenciadas por ele em eventos que aconteceram em alguma fase de sua formação cultural e social.

Começo, numa perspectiva de história individual, por esclarecer as diferenças entre as emoções que experienciamos na infância, para as quais um "mecanismo pré-organizado" de tipo jamesiano será suficiente, e as emoções que experienciamos em adulto, cujos andaimes foram gradualmente construídos sobre as fundações daquelas emoções "iniciais". Proponho chamar às emoções "iniciais" primárias e às emoções "adultas" secundárias (DAMÁSIO, 2006, p. $160)$.

Já em "Em busca de Espinosa" (2004), Damásio classifica as emoções em três categorias: as emoções de fundo, que podem ser detectadas pelo comportamento das pessoas (movimentos corporais, expressões faciais); as emoções primárias ou básicas, o medo, a raiva, o nojo, a surpresa, a tristeza, a felicidade; e as emoções sociais, a simpatia, a compaixão, o embaraço, a inveja, a gratidão, a indignação, o desprezo, "numerosas reações regulatórias (que afetam sobremaneira as emoções de fundo), bem como componentes das emoções primárias, são parte integrante, em diversas combinações, das emoções sociais" (DAMÁSIO, 2004, p. 51-54).

Damásio fez uma reclassificação entre as categorias apresentadas. Dividiu a categoria "primária" em "emoções de fundo" e "emoções primárias ou básicas", e reforçou ou explicitou melhor a categoria secundária, a qual chamou de "emoções sociais". 


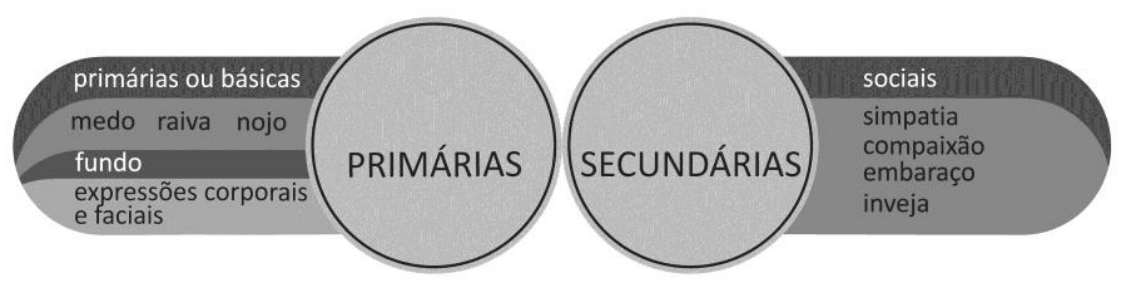

Figura 8 - Classificação das emoções - Damásio (2004) e (2006). Adaptado pela autora

Para tanto, podemos concluir que as emoções estão intimamente atreladas aos valores subjetivos do indivíduo, valores esses que podem ser formados pela história individual; podem ser resultados de um estágio cultural; ou ainda, serem comuns a toda a humanidade.

Para o design, isso quer dizer que todas as coisas materiais suscitam emoções: fortes ou brandas, positivas ou negativas, conscientes ou inconscientes e que é muito pouco provável que haja objetos emocionalmente neutros porque conforme o indivíduo, um grupo de pessoas ou a sociedade como um todo se desenvolvem psicologicamente, socialmente e culturalmente, os objetos ao redor tendem a perder sua "inocência emocional [...] as coisas materiais fazem parte do palco em que se dão as nossas ações cotidianas, têm "vida social" e "competência emocional" e não são emocionalmente neutras" (DAMAZIO; LIMA; MEYER, 2008, p. 83).

Assim, qualquer objeto que se proponha a uma interação com o indivíduo poderá suscitar reações emocionais. Relacionando as proposições de Damásio (2004) com as de Norman (2008) já citadas anteriormente, num primeiro momento surgem as emoções de fundo, num design visceral, que por sua cor, forma, textura, dimensões leva o objeto a chamar a atenção ou "afetar" o indivíduo, que pode lançar um olhar de espanto, de curiosidade. Depois, é a vez das emoções primárias, num design comportamental, no qual acontece o processo de interação de uso e compreensão do objeto. Nesse processo são suscitadas as emoções positivas ou negativas, como surpresa ou repugnância. Nos dois primeiros processos, a relação entre o indivíduo e o objeto acontece no nível subjetivo, mas pode ter influência do meio. Por último, vêm as emoções sociais, que podemos relacionar ao design reflexivo. Aqui surgem questões de juízo e comparação, e emoções como inveja ou simpatia podem ser despertadas. 


\begin{tabular}{|l|l|l|l|}
\hline \multicolumn{1}{|c|}{$\begin{array}{c}\text { EMOÇÕES } \\
\text { (Damásio, 2004) }\end{array}$} & \multicolumn{1}{c|}{$\begin{array}{c}\text { DESIGN } \\
\text { (Norman, 2008) }\end{array}$} & \multicolumn{1}{|c|}{ EMOÇÕES GERADAS } & \multicolumn{1}{|c|}{ OBJETOS } \\
\hline Fundo & Visceral & Espanto, curiosidade & Cor, textura, dimensões \\
\hline Primárias & Comportamental & Repugnância, surpresa & $\begin{array}{l}\text { Processo de uso e } \\
\text { compreensão dos } \\
\text { objetos }\end{array}$ \\
\hline Sociais & Reflexivo & Inveja, simpatia & $\begin{array}{l}\text { Significados, juízos, } \\
\text { comparação }\end{array}$ \\
\hline
\end{tabular}

Figura 9 - Comparação entre as emoções

geradas,Damásio (2004), e

tipos de design, Norman (2008).

Segundo Forlizzi, Disalvo e Hanington (2003), nenhuma característica formal do objeto - leia-se forma, cor, dimensões - pode ser considerada como responsável de uma resposta emocional específica. A qualidade emocional de uma experiência é o efeito de um ajuste de várias emoções que se combinam e alteram-se reciprocamente, e que se dá verdadeiramente pela reflexão sobre a experiência trabalhada pelo tempo. Para tanto, a qualidade emocional é mais que aquilo que está no objeto, é uma situação que configura a informação recebida do ambiente e o modo como a pessoa se relaciona com a condição real (dada) ou imaginada do mundo.

Todas as emoções originam sentimentos, contudo nem todos os sentimentos advêm de emoções. Os sentimentos que não se originam das emoções são considerados aqueles de fundo e são como que uma imagem do panorama do corpo quando esse não se encontra agitado pela emoção. Damásio (2006) se refere ao sentimento como aquele que resulta da percepção de todas as mudanças que constituem a resposta emocional; um processo de acompanhamento contínuo das experiências que formam no organismo uma paisagem corporal capaz de ser interpretada pelo nosso sistema neural.

[...] além de estarem ligados a um objeto imediato, o corpo, os sentimentos estão também ligados ao objeto emocionalmente competente que deu início à cadeia emoção - sentimento. De uma forma bem curiosa, o objeto emocionalmente competente (estímulo) é responsável pelo estabelecimento do objeto (construção interna que o cérebro faz desse objeto) que está na origem imediata do sentimento. (DAMÁSIO, 2004, p. 98)

Essa colocação de Damásio é questão central para o desenvolvimento do pensamento aqui proposto. Dos sentimentos gerados pelos objetos emocionalmente competentes (objetos de design) depende a construção da imagem ou construção interna que fazemos daquele objeto. Assim, qualquer relação (avaliação ou juízo) que viermos a 
ter com ele ou com outros, novas imagens serão construídas e, segundo Hillman (1995), tudo vai depender da maneira como olhamos para aquele objeto e quais sentimentos serão gerados a partir daquele olhar.

Sendo assim, a emoção pode ser considerada um conjunto de modificações que acontecem tanto no cérebro (mente) quanto no corpo e que, na maioria das vezes, têm como fonte um determinado conteúdo mental. Por outro lado, o sentimento seria a percepção dessas modificações.

[...] o impacto humano de todas essas causas de emoções, refinadas e não refinadas, e de todas as nuances de emoções sutis ou não sutis que elas induzem depende dos sentimentos engendrados por essas emoções (DAMÁSIO, 2006, p. 56).

Enquanto registro das emoções, os sentimentos sempre agirão quando o indivíduo estiver frente a uma situação que possa evocá-los, e reproduzirão emoções positivas ou negativas em relação a esse novo estímulo a partir de afinidades a experiências anteriores (DAMÁSIO, 2006). Caso se trate de um objeto novo e ele não consiga falar de si próprio usando uma linguagem decodificável pelo sentimento, o indivíduo utiliza o mesmo julgamento de uma experiência já ocorrida em situações similares, conforme nos é descrito,

Os sentimentos [...] resultam do julgamento de uma experiência direta com o objeto ou evento e uma conseqüente generalização para outros objetos do mesmo tipo. As pessoas simplesmente gostam de uma interface que é fácil de usar e é bonita. Sentimentos desse tipo tendem a persistir indefinidamente (mais do que emoções e humores) e tornam as pessoas propensas ou relutantes a reproduzi-las nas experiências com objetos do mesmo tipo. Assim, é altamente recomendável que as pessoas tenham boas experiências e desenvolvam sentimentos positivos. (CYBIS; BETIOL; FAUST, 2007, p. 325)

c) Sentidos

Definidos como sistemas sensoriais que desempenham a importante função de manter o cérebro em constante atualização sobre as atividades do mundo externo, os sentidos são capacidades pelas quais os indivíduos percebem e acompanham a realidade em sua volta (KANDEL; SCHWARTZ; JESSEL, 1997). 
Dutcosky (2007) diz que o cérebro detecta e assimila concomitantemente as informações advindas das cinco vias sensoriais e que sempre há intercâmbios e associações psicológicas. A autora afirma que o nível de educação, personalidade, nível social e cultural são elementos que auxiliam um estado único em que o indivíduo se encontra, visto que as pessoas podem ter diferentes graus de sensibilidade para cada um dos sentidos, dando para cada sujeito um olhar particular do mundo e da realidade. Para tanto, podemos dizer que os sistemas sensoriais assimilam as manifestações do mundo externo e delas retiram dados que norteiam o comportamento.

Atualmente os sentidos são classificados de diferentes maneiras, não mais pautados naquelas categorias que se prendiam aos cinco sentidos básicos. Durie (2008) aponta uma classificação que se dá pela natureza do estímulo: químico (gustação e olfato), mecânico (tato e audição) e luminoso (visão). Já para Pisani et al. (2000), são dez as categorias: visão, audição, olfato, paladar, tato, frio, calor, dor, cinestesia e equilíbrio. Cabe observar que esses últimos autores fazem uma separação entre tato, dor, calor e frio, sendo que normalmente encontraríamos dor, calor e frio como sentido tátil.

Podemos dizer que a intensidade e a quantidade de experiências sensoriais advêm de muitos fatores, dentre eles o bom ou o mau funcionamento dos órgãos dos sentidos. Por outro lado, é fato também que o indivíduo não consegue ter consciência de todos os estímulos recebidos pelos seus sentidos. Como diz o ditado popular: "Não sentimos duas dores ao mesmo tempo".

Em uma pesquisa sobre o uso dos sentidos pelo mercado, Lindstrom (2007) detectou que os sentidos das pessoas estão mais sintonizados para detectar uma situação de perigo do que para expectativas de prazer sensorial. Concluiu também que, em se tratando da avaliação do ambiente, a visão é a mais utilizada, seguida pelo olfato e, por último, o tato. Contudo, de uma maneira geral, o autor diz que na pesquisa as diferenças entre os sentidos foram pequenas e que todos eles são importantes em qualquer forma de comunicação e experiência.

Atualmente podemos reparar uma infinidade de empresas, como lojas, que utilizam os sentidos para conquistar consumidores. Ambientes aromatizados, com iluminação diferenciada, e distintos usos de cores e texturas.

A marca brasileira Body Store, fundada em Porto Alegre em 1997, trabalha com cosméticos artesanais e usa dessa estratégia em suas lojas. Possui uma grande diversificação de produtos (sabonetes, cremes, shampoo, sais de banho, entre outros) 
que se apresentam de forma diferenciada com cores, texturas e fragrâncias. Os ambientes das lojas são projetados com o objetivo de explorar sensorialmente a interação dos produtos comercializados com os clientes. O lema da marca é o de que as pessoas têm poucos momentos para cuidarem de si mesmas, assim seus produtos devem transformar os pequenos momentos do dia a dia em experiências sensoriais únicas.

A brasileira Farm, marca de roupas femininas, também aposta na ideia. Os ambientes de suas lojas são aromatizados, e esse aroma virou um Home Spray a pedido das consumidoras.

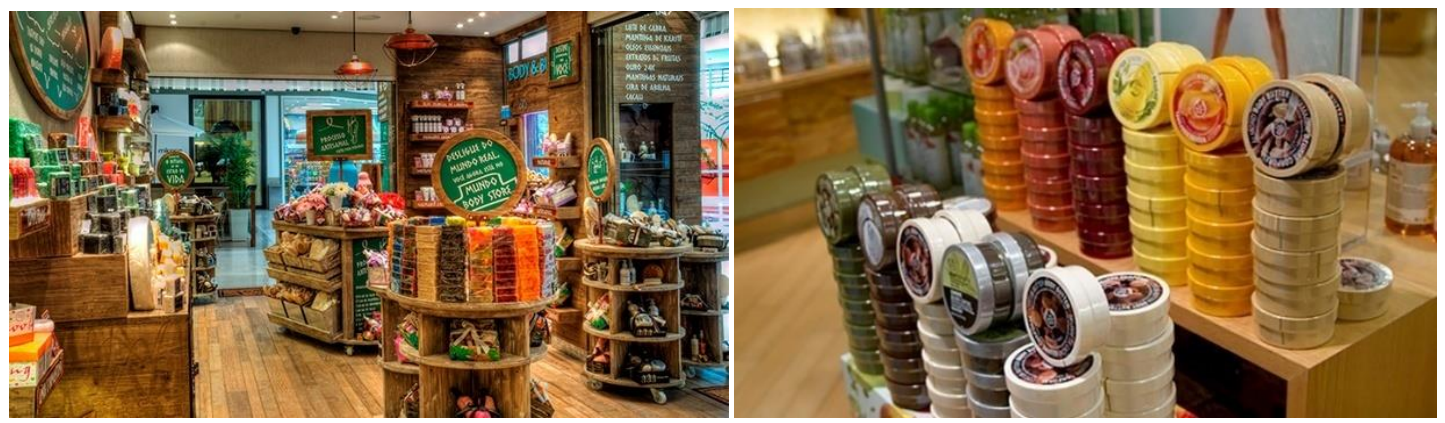

Figura 10 - Ambientes da Body Store que utilizam em seus interiores aromas personalizados, cores e texturas

d) Percepções e sensações

Perceptualmente falando, a tomada de consciência do que é "realidade" e "mundo" é uma incessante construção fundamentada naquilo que os sentidos e a percepção conseguem informar. Essa construção é realizada segundo aquilo que foi percebido em cooperação com a memória e o raciocínio, pois

Existe uma consciência notável nas construções que diferentes indivíduos elaboram relativas aos aspectos essenciais do ambiente (texturas, sons, formas, cores, espaço). [...] Não sabemos, e é improvável que alguma vez venhamos a saber, o que é realidade absoluta. (DAMÁSIO, 2006, p. 124)

Para tanto, entendemos que a construção de um panorama e a avaliação da realidade ambiental se dão quando os sentidos detectam os estímulos externos. Ao detectar informações, o cérebro estabelece uma representação interna a partir dos eventos físicos externos. Segundo Kandel; Schwartz e Jessel (1997), as percepções não 
são registros diretos do mundo, mas construções internas obtidas de acordo com os princípios inatos e os alcances colocados pelas capacidades do sistema nervoso, os quais interagem com as experiências individuais coordenadas pela cultura em que o sujeito se insere. Assim, as percepções são qualitativamente diferentes das características físicas dos estímulos, pois o sistema nervoso retira somente algumas informações do estímulo, e as interpreta conforme a experiência já adquirida.

Arnheim (2001, p. xiii), em estudos relacionados à percepção visual por meio da teoria da Gestalt, coloca que somos pessimamente acostumados a negligenciar o dom de compreender as coisas por meio dos nossos sentidos, a divorciar o conceito daquilo que percebemos. Diz: “[...] [sofremos] de uma carência de ideias exprimíveis em imagens e da capacidade de descobrir significado no que vemos". Temos de ter a capacidade, como também defende Damásio, de não separar corpo e mente, e sim sermos capazes de sentir e descobrir significado naquilo que nos chega pelos sentidos.

Para Dember (1990) e Pisane (2000), o indivíduo capta os estímulos do ambiente e transforma-os em cognição a fim de facilitar suas respostas adaptativas, e defendem que sensação e percepção estão atreladas em um único processo complexo e contínuo.

Mais especificadamente, a sensação está associada a um primeiro contato entre o sujeito e o seu entorno. Os sentidos disponibilizam um processo de captação e codificação iniciais para a sensação. É a quantidade e a intensidade dos estímulos que definem, por sua vez, a intensidade ou quantidade de sensação. Existe um "limiar sensorial", que é quando o estímulo mais fraco pode ser detectado. Esse limiar é variável e pode ser influenciado pela fadiga, pela experiência ou pelo contexto no qual o estímulo é apresentado.

Segundo Durie (2008), a percepção é um refinamento, um valor agregado que o cérebro afere às informações sensoriais brutas. A percepção está ligada à interpretação, na qual significados, juízo, contexto, experiência passada e memória exercem função significativa (PISANI et al., 2000; ASHBY; JOHNSON, 2002).

Kandel; Shwartz e Jessel (1997) dizem que nem todas as informações sensoriais chegam à consciência apesar de parecer que a sensação acontece como uma experiência consciente. Por isso que a atenção é uma condição primordial para que haja uma percepção, pois é por meio dela que se faz a seleção dos estímulos. 
contemplar esse panorama é o objeto imediato que está na origem do sentimento, e é objeto cuja percepção constitui a essência do sentimento (DAMÁSIO, 2000, p. 98-99).

Assim, a percepção é um fenômeno resultante da combinação de estímulos internos e externos, sendo que os internos são aqueles que se reportam às memórias que os indivíduos trazem consigo e os externos são os apresentados pelo entorno, e isso inclui os objetos.

A realidade interna (o subjetivo) é formada pelo cérebro enquanto interage com o momento presente, tendo como contexto suas experiências passadas e expectativas para o futuro, por isso é que cada pessoa experimenta de forma singular o imaginar o mundo.

Se você olhar pela janela para uma paisagem de outono, se ouvir a música de fundo que está tocando, se deslizar seus dedos por uma superfície de metal lisa ou ainda se ler estas palavras linha após linha, até o fim da página, estará formando imagens e modalidades sensoriais diversas. As imagens assim formadas chamam-se imagens perceptivas (DAMÁSIO, 2006, p. 123).

As imagens guardadas na memória, ou no imaginário (ALMOUNT, 1993), colaboram para que a percepção seja um processo extremamente particular e em constante renovação (SIEGEL, 2004).

\begin{abstract}
A mente constrói a realidade perceptiva a partir de segmentos de informações selecionadas que recebe através dos sentidos, em combinação com processos mentais extremamente subjetivos e sensíveis ao contexto, tais como modelos mentais e a influência da emoção. (SIEGEL, 2004, p. 220)
\end{abstract}

As imagens em si são reais. Antes que haja o processo de percepção, as imagens já existem e não significam coisa alguma, há apenas propagação. O que existe na realidade é o que individualmente sentimos quando vemos, ou seja, nossa "vivência afetiva" (BECCARI, 2012, p. 285). E é pelo processo de percepção que a imagem é sentida.

Damásio diz que as imagens também podem ser puramente mentais, independentemente de serem constituídas por formas, cor, movimentos ou palavras emitidas. $\mathrm{O}$ autor define como imagens evocadas aquelas geradas por sentimentos e memórias de coisas passadas. 
A natureza das imagens de algo que ainda não aconteceu, e pode, de fato, nunca vir a acontecer, não é diferente da natureza das imagens acerca de algo que já aconteceu e que retemos. Elas constituem a memória de um futuro possível e não de um passado que já se foi. (DAMÁSIO, 2006, p. 124).

Karana e Kesteren (2006) afirmam que as experiências são constituídas por uma gama de dimensões: os materiais, o uso e a função assumida, por exemplo. Identificam que o modo como as emoções são geradas pelo corpo é um atributo intrínseco ao ser humano, podemos até dizer que é uma característica universal. As experiências é que são únicas.

Emocionar-se é da natureza do homem, pois ele tem dispositivos corporais que lhe permitem isso. Entretanto, não temos como alcançar o sentir do outro, fazendo que a experiência seja individual e única.

É nessa perspectiva que se coloca o objeto na sua primeira apresentação ao usuário: a promessa de experiência que ele pode oferecer.

\section{e) Experiência}

Define-se experiência como sendo um fluxo constante que ocorre durante momentos de consciência (FORLIZZI; FORD, 2000). Segundo Hekkert e Russo (2008), duas perspectivas sobre experiência são trabalhadas no design. A primeira é a user experience: mais centrada nas questões cognitivas. A segunda, product experience, trata de todas as experiências afetivas envolvidas na interação do produto com o homem, seja instrumental (interação com o produto para realizar uma tarefa), não instrumental (manipulação do produto sem fins práticos), ou não física (mental, quando o indivíduo pensa no produto, antecipando futuras interações ou se lembrando de interações passadas). Product experience é considerada

um conjunto de efeitos provocados pela interação entre uma pessoa e um produto, incluindo o grau em que todos os nossos sentidos são gratificados (experiência estética), os significados que damos aos produtos (experiência de significado) e os sentimentos e emoções que são evocados (experiência emocional) (HEKKERT, 2006, p. 160). 
O próprio autor, contudo, diz que é difícil distinguir os três níveis de experiência, a estética, a emocional e a de significado, pois além das diferenças conceituais entre eles, experienciamos "uma unidade de encanto sensual, interpretação significativa e envolvimento emocional, e somente nessa unidade podemos falar em uma experiência" (HEKKERT, 2006, p. 159). Para Forlizzi e Ford (2000), as experiências fazem o papel de aglutinadores de uma gama de outras experiências menores onde a antecipação e recordações de experiências geram outras experiências. Segundo Jääskö et al. (2003), as experiências acontecem ao mesmo tempo em um complexo sistema de aspectos dinâmicos.

Há muitas propostas e abordagens acerca da experiência no design. A maior parte está ligada a certas características de interação e introduziu "conceitos experienciais" afetivos, como beleza na interação; apego; engajamento; divertimento (HEKKERT; RUSSO, 2008). Contudo, segundo os autores, essas propostas são limitadas quanto às estratégias claras de aplicação e ao nível de informação sobre o conceito experiencial em si, pois, uma vez que não podemos nomear e tampouco identificar a experiência, fica mais complicado ter uma ideia clara do que de fato ela é, em termos absolutos, e o que abrange.

Hekkert e Russo (2008) dizem que é possível projetar experiências e propõem uma estrutura composta por três níveis de informação experiencial: 1) teorias gerais e fundamentais sobre a experiência; 2) conceitualização da experiência no âmbito do design; e 3) princípios fundamentais e estratégias para se projetarem experiências. Em estudo, apresentam o desenvolvimento da estrutura por meio do terceiro tópico (princípios fundamentais e estratégias para se projetarem experiências) usando, como exemplo, a experiência do "amor" (love), que, em tradução para o português, seria adorar, gostar muito, ou seja, por que adoramos usar um produto. Nesse estudo, os autores usaram a técnica da análise de estórias (narrativas) sobre o relacionamento entre as pessoas e seus produtos adorados em uma relação mais ampla, não somente naquela baseada na interação física e de uso, e propõem cinco princípios que regem a experiência de "adoração" (amorosa) das pessoas com seus produtos. Os cinco níveis são:

a) Interação fluida - quando indivíduo e produto interagem fluentemente. $\mathrm{Ou}$ seja, quando se tem uma resposta imediata e direta dessa interação; quando há um equilíbrio entre o nível de habilidade e o de desafio; quando o 
indivíduo tem um sentimento de controle sobre a situação ou atividade; e quando a atividade se torna compensadora.

b) Lembrança de memória afetiva - objetos que contêm e suprem as memórias afetivas têm o poder de prender e soltar as memórias que as pessoas neles investem, contribuindo assim para a existência do apego entre as pessoas e os produtos. Esse nível abrange o indivíduo, o subjetivo.

c) Significado simbólico (social) - semelhante ao item anterior, porém em situação coletiva, social. Neste caso, o significado aqui suscitado são os significados expostos a outras pessoas, num nível social. Construção, familiarização e comunicação da autoidentidade de uma pessoa junto aos outros.

d) Compartilhamento de valores morais - as pessoas se interessam por produtos pelos quais elas possam compartilhar e dividir valores éticos e morais.

e) Interação física prazerosa - diz respeito ao quanto um produto pode gratificar os nossos sentidos, principalmente o tato. Segundo Hekkert (2006), o toque nos traz informações sobre o mundo à nossa volta e também nos torna conscientes quanto ao nosso próprio corpo, o que nos leva à experiência enquanto ser.

Os estudos de Hekkert e Russo (2008) sobre a emoção love apresentam uma importante constatação de como as pessoas se relacionam com seus pertences, seja no nível individual (subjetivo) ou social (coletivo). Elas dão e esperam de seus objetos uma relação de prazer, satisfação e compartilhamento de suas expectativas, capaz de propiciar ao indivíduo uma evasão da cotidianidade formando, no meio privado, uma esfera ainda mais privada.

Com relação à experiência tátil especificamente, Sonneveld (2007) diz que os produtos têm propriedades que podem ser relacionadas à experiência tátil por quatro níveis:

a) Substância do material - relativo à dureza, plasticidade, temperatura, elasticidade, composição e peso.

b) Aspecto ou estrutura geométrica - volume, equilíbrio e forma global.

c) Superfície - textura e padrões.

d) Partes - a maneira como as partes se relacionam e se movem umas em relação às outras. 
Essas propriedades físicas dos objetos influenciam sobremaneira os níveis visceral e comportamental no uso dos objetos, bem como o nível reflexivo. É por meio dessas características que os objetos, que são manipuláveis, nos chegam aos sentidos, consequentemente à percepção.

Assim, defendemos a posição de que os designers precisam desenvolver a capacidade de se comunicar e se tornar mais enfáticos em relação às pessoas para as quais eles projetam, pois, deste modo, ele se tornará uma espécie de "organizador" de múltiplas sintaxes culturais, perceptivas e emocionais e projetará um "feixe" (produto) no qual será possível encontrarmos o indivíduo.

Quando defendemos, mais uma vez, que designers devem unir, aproximar, articular realidades, estamos nos referindo exatamente a essa questão. Os designers precisam entrar no universo subjetivo dos indivíduos, entender o que e como pensam, o que e como sentem, o que e como gostam; e no nível intersubjetivo, como se relacionam entre eles e com o mundo, segundo os preceitos individuais e coletivos.

Pensar em ações, como a de sentar, por exemplo, enquanto experiência e não enquanto um objeto com a função sentar, como uma cadeira, faz:

a) Para o designer, enquanto situação projetual, libertar-se das desgastadas estruturas preexistentes e ter a possibilidade de criar soluções verdadeiramente inovadoras;

b) Para o objeto, enquanto situação de uso, ganhar uma dimensão poética, uma produção de sentido;

c) Para o indivíduo, usuário, adquirir o poder de ressignificar aquele objeto.

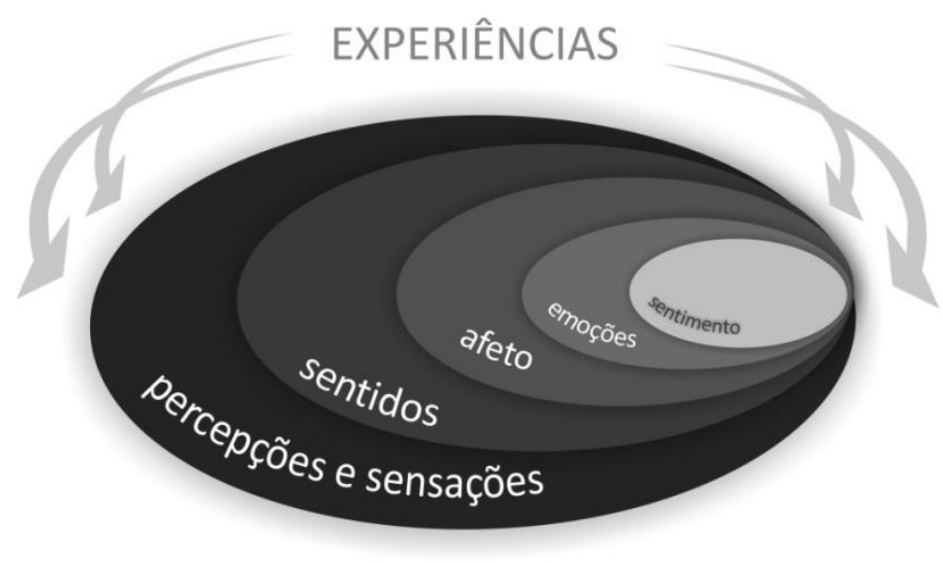

Figura 11 - Processo experiencial, perceptivo e emocional 


\subsection{0 móvel e suas características funcionais}

Vimos ao longo do texto explanando sobre a capacidade dos objetos em suscitar emoções às pessoas por meio de relações. Para tanto, entendemos que é de importância fundamental o entendimento dessas relações e por quais mecanismos elas se dão. Assim, acreditamos que os objetos assumem funções na vida das pessoas, e é por meio dessas funções que as relações são estabelecidas.

É comum certa generalização e confusão no uso do termo "função" para designar funcionamento, operacionalidade e significado ao mesmo tempo. Isso se dá por influência do Funcionalismo, para o qual os objetos possuíam apenas uma função, a utilitária ou de uso, como já explicitado no início do capítulo 1. No entanto, como sabemos, os objetos contêm características físicas e significativas que vão além da questão da função de uso. Assim, utilizaremos o termo "funções" para dizer que os objetos assumem funções com valores e conceitos bastante distintos entre si.

Como exemplifica Denis (1998, p. 33), um mesmo produto pode cumprir funções e ter significados diferentes. Para o autor, os artefatos têm significados "universais e inerentes (as garrafas são feitas para conter líquido)", e “outros extremamente pessoais e volúveis (papai usava esta garrafa para guardar o seu conhaque especial)". Uma bicicleta, por exemplo. Para alguns, pode ser considerada um veículo utilitário de transporte; para outros, um veículo de lazer.

Para tanto, como já defendido, os objetos não apresentam características somente consideradas objetivas e técnicas, mas, e principalmente, aspectos que necessitam de interpretações pessoais e particulares, assumindo funções e significados distintos para cada indivíduo e grupo social.

Seja como um produto único, ou de produção em grande escala, seja tanto para o usuário quanto para o produtor, o objeto tem de ter qualidades que correspondam a necessidades. A principal finalidade de um objeto é satisfazer a uma ou mais necessidades, ou seja, atender às funções demandadas pelos envolvidos no processo de produção, uso e significação.

Os móveis, objetos físicos desta pesquisa, assim como a maioria daqueles que são construídos pelo homem, possuem elementos constitutivos básicos que definem a sua existência. Em uma análise geral, derivada do meio produtivo (seja artesanal ou industrial) e do meio daqueles que de alguma maneira estão envolvidos no setor, podemos designar três elementos: os elementos técnicos, os elementos estéticos e os 
elementos de destinação. Os elementos técnicos podem ser divididos em elementos construtivos ou aqueles procedentes da fabricação - o processo de fabricação e montagem, por exemplo; e em elementos utilitários, aqueles que envolvem a comodidade de uso e condições práticas. Os elementos de ordem estética são aqueles que compreendem a qualidade formal e o valor plástico do móvel. Já os elementos de destinação, os que definem a que propósito os móveis são utilizados, ou seja, o uso.

Ao analisar o mobiliário antigo da Bahia, considerado como mobiliário artístico e de distinção social, Rocha (s.d., p. 8) pondera que a dimensão estética compreende a forma do móvel e sua decoração. À forma, o autor vincula os elementos utilitários e diz que estão atrelados por causa das convenções de uso. À decoração, define os processos pelos quais o artista se utiliza para "embelezar", tornando o móvel capaz de "despertar emoção estética, prazer de contemplação, satisfação enfim". E complementa que os procedimentos decorativos empregados no mobiliário em questão são aqueles considerados tradicionais e utilizados pela arte: escultura, gravura, pintura e incrustações.

[...] se uma cama, uma mesa, um banco apresentam formas proporcionais às suas dimensões, se têm linhas agradáveis e equilibradas e ostentam decoração condizente com seu espírito, são qualificados como de qualidade artística. (ROCHA, s.d., p. 9)

A evolução dos aspectos da "forma e da decoração" se constitui na própria história do estilo no mobiliário. Esses aspectos serão mais bem comentados no capítulo 3.

Outra categorização de Rocha diz respeito à destinação. O autor os classifica em móveis de guarda e móveis de repouso.

Canti (1980), também faz uma classificação quanto à destinação do móvel. Assim como Rocha, diz que se divide em móvel de guarda e móvel de repouso, mas acrescenta as categorias: móvel de descanso e móvel de utilidade.

As categorias apresentadas pelos autores acima foram estabelecidas a partir de uma concepção tradicional, na qual os objetos se tornam símbolos dos propósitos de suas funções de uso e forjados pela própria experiência vivida, criados pela praxis cultural e social e por influências dos contextos artísticos. 
Já Baudrillard (1993), ao analisar os objetos dentro do sistema moderno, diz que os móveis se tornaram multifuncionais, arranjados em várias combinações e de uso diversificado: o objeto que, liberto de sua função de uso, torna-se um signo.

Independentemente de uma classificação dentro de um "sistema tradicional" ou "moderno", o fato é que os móveis são objetos que se prestam às várias funções e destinados a suprir alguma necessidade.

Acerca das funções dos objetos, e neles também são incluídos os móveis, faremos a seguir um detalhamento mais elucidativo.

\subsubsection{As funções dos objetos}

O ambiente humano ${ }^{10}$ é fruto de um acúmulo de objetos que foram desenvolvidos independentes uns dos outros e que, mediante a soma e suas interrelações funcionais, determinam o quadro representativo desse entorno. Esse conjunto de objetos acaba influenciando a conduta dos homens que vivem dentro deste ambiente.

Para Moles (1981, p. 27), o objeto é "um elemento do mundo exterior fabricado pelo homem e que este pode segurar e manipular". Assim, um objeto é algo fabricado pelo homem e torna-se utilitário a partir do momento em que é manipulado e destinado a cumprir uma necessidade.

Afirmamos anteriormente que os objetos são signos que expressam utilidades e estimulam os sentidos. Segundo Barthes (1978), além de os objetos terem a finalidade utilitária, também comunicam informações, em que o sentido ultrapassa o próprio uso.

Para Löbach (2000), o objeto utilitário, por estar inserido no cotidiano das pessoas, possui características estéticas e simbólicas. Assim como Löbach, Moles (1981) também defende que o objeto utilitário cumpre uma função estética intensa e contígua e é o grande responsável pela estética do cotidiano.

Moles (1981, p. 18) classifica alguns tipos de relação entre o homem e o objeto. Dentre eles, destaca o modo funcionalista e o modo hedonista. No modo funcionalista, os objetos são propostos para cumprir uma determinada ação para atender a um determinado fim. No hedonista, é quando há um prazer das coisas, “[...] um prazer de segurar na mão um belo objeto [...]". Entendemos a afirmação de Moles como positiva

10 Definimos ambiente humano como aquele que é da natureza do homem construir o artefato (ver MATURANA, 2001) 
por dois motivos. Primeiro, porque, ao destacar dois modos de relação, o autor realça que os objetos possuem outras qualidades funcionais, não apenas aquelas que dizem respeito à utilização. Segundo, apesar do emprego do termo "hedonista" nos remeter a algo imediato ou efêmero, e que não é apenas um "belo objeto" que nos dá prazer ao ser utilizado, a afirmação do autor chama a atenção porque nos leva a considerar que há, na relação entre indivíduo e objeto, situações que nos remetem à experiência emocional.

O autor coloca ainda que a relação entre homem e objeto perpasse por quatro etapas: o desejo, dado pela aquisição; a descoberta; a relação afetiva; e por fim, o declínio da relação, no qual o objeto pode ser descartado, substituído ou preservado. Entendemos que todas as etapas citadas por Moles - desejo, descoberta, relação afetiva e declínio da relação - são inerentes aos componentes emocionais, pois é um processo no qual houve um despertamento (desejo), uma paixão e um uso (a descoberta e relação afetiva), e uma finalização do processo de uso (declínio da relação). Assim, o objeto que se "usou", se "gastou" e se "acabou", foi "consumido" não por aquilo que nele fica retido, mas por aquilo que se passou através do objeto.

Vários autores trabalham acerca das definições das funções dos objetos.

Dufrenne (1998), numa visão tecnicista, seguindo as proposições de G. Simondon, ${ }^{11}$ situa os objetos em duas categorias: o objeto técnico e o objeto estético. Para Dufrenne, o objeto estético é aquele que provoca a percepção estética na qual o belo será realizado e consagrado. Nele o que está em jogo é o sentimento. Para o usuário ou espectador, o objeto estético é concreto, existe inteiramente, decisivamente, segundo uma necessidade intrínseca, no domínio do sensível.

[...] o objeto estético solicita, para se realizar, que nos associemos a ele, que reaprendamos o gesto do criador e que penetremos no seu mundo, ele apela para o sentimento em nós [...] (DUFRENNE, 1998, p. 245).

Já para o objeto técnico, o autor diz,

[...] a norma que o governa lhe é exterior: o seu sentido não é necessário, imanente, à sua forma [...] um motor não diz nada ao ignorante; se ele fala ao mecânico, é com sua estrutura e não com o seu próprio mostrar-se; ele não faz signo, ele é um sistema de signos

11 G. Simondon estudou "a gênese e a evolução dos objetos técnicos" por meio de uma gênese da tecnicidade, para situar o pensamento técnico. Ver SIMONDON, Gilbert. Du mode d'existence dês objects techniques, Paris: Aubier, 1989. 
cuja significação é necessário conhecer de antemão (DUFRENNE, 1998, p. 244).

[...] objeto técnico é ao mesmo tempo, em relação ao mundo, separado

e separante, e ele mesmo também separado [...] (DUFRENNE, 1998,

p. 246).

Dufrenne ainda faz uma distinção entre objeto técnico e objeto de uso. O autor os resume como aqueles que têm em comum o "fato de serem fabricados, atestarem tecnicidade e servirem como meio a fins" (DUFRENNE, 1998, p. 242).

O que nos interessa nas categorias de Dufrenne é quando o autor relaciona a experiência estética, que conceitualmente vem da experiência com a obra de arte, ao mundo da técnica. É por duas vias que o autor defende sua ideia. A primeira é quando a técnica proporciona novos horizontes à arte, não só para o artista com novos meios de expressão, mas à sensibilidade do espectador, que descobre novos domínios. A segunda diz respeito aos objetos de uso, nos quais a experiência estética pode ser vivida no "meio técnico" ou no cotidiano. É justamente essa inserção no mundo que estetiza o objeto técnico: "Ele é belo ao encontrar um fundo que lhe convém, ao contemplar e exprimir o mundo" (DUFRENNE, 1998, p. 254). É a "estetização do cotidiano", tão reclamada e conclamada quando da passagem dos processos artesanais para os industriais nos idos do século XIX.

No design, alguns teóricos tentam propor diretrizes para um melhor entendimento acerca da relação indivíduo e objeto, e sobre quais seriam as funções que os objetos teriam de cumprir nessa relação. Com o objetivo de elucidar o entendimento a respeito de nossa proposta, primeiramente discorreremos sobre as proposições de Bernard Löbach (2000), em seguida apresentaremos a nossa.

Assim como os outros autores, Löbach (2000) coloca que muitas das necessidades dos homens são satisfeitas pelo uso dos objetos, e que isso ocorre pelo processo de utilização por meio das funções dos produtos que se manifestam como valores de uso.

Löbach diz que os objetos industriais possuem três funções distintas: função prática, função estética e função simbólica.

A função prática é definida como aquela em que a relação usuário-produto se dá no nível orgânico-corporal, isto é, fisiologicamente: "São funções práticas de produtos todos os aspectos fisiológicos de uso" (LÖBACH, 2000, p. 58). Uma cadeira, por exemplo. De um modo geral, uma cadeira é usada para que o corpo assuma uma posição 
de descanso, por meio de algumas funções práticas como, entre outras: o assento deve suportar o peso do usuário; deve permitir que a borda não prejudique a circulação sanguínea; sua superfície deve permitir ventilação para que o corpo não acumule suor; o encosto deve suportar a coluna e permitir posição de descanso.

A função estética é quando a relação se dá pelos processos sensoriais: “A função estética dos produtos é um aspecto psicológico da percepção sensorial durante o seu uso" (LÖBACH, 2000, p. 59-60). Segundo o autor, a função estética é uma das determinantes na compra de um produto, pois ela permite uma visão geral, total do produto, como se sensorialmente o usuário "sentisse" o objeto em sua totalidade. Acreditamos que o autor faz essa análise usando o princípio de avaliação no qual a "apreciação" sensível, que não é tributária das categorias conceituais ou utilitárias, e, portanto, se distingue do juízo lógico e do juízo prático, é calcada no ajuizamento do gosto. Podemos dizer que é nessa fase, ou com essa função, que é despertada a primeira etapa da relação emocional, o afeto.

A terceira classificação de Löbach é a função simbólica. Para um objeto, a função simbólica atua quando "a espiritualidade do homem é estimulada pela percepção deste objeto, ao estabelecer ligações com suas experiências e sensações anteriores [...] a função simbólica dos produtos é determinada por todos os aspectos espirituais, psíquicos e sociais do uso" (LÖBACH, 2000, p. 64). Para o autor, essa função deriva da função estética, dos aspectos formais do objeto. Por meio dos elementos expressivos como cor, forma, material, ou seja, daquilo que é percebido sensorialmente, e da capacidade mental de associação de ideias é que a função simbólica será efetivada. É a função simbólica que possibilita ao homem fazer associações com as experiências passadas.

Para maior esclarecimento daquilo que em seguida apresentaremos, achamos por bem nos deter um pouco na função simbólica de Löbach.

Ao definir a função simbólica dos produtos como aquela que "é determinada por todos os aspectos espirituais, psíquicos e sociais do uso" (grifo nosso), o autor está utilizando um conceito de símbolo que remete a um processo de internalização do sujeito, ou seja, uma dimensão subjetiva. Nesta vertente de pensamento, o símbolo é como um "algo significativo" que está situado entre o consciente e o inconsciente. Podemos considerá-lo como uma "ponte" que liga os dois extremos, e que tem o papel de unir o sentido do consciente às imagens do inconsciente. 
[...] o símbolo, em sua essência e quase em sua etimologia (Sinnbild, em alemão), é unificador de pares opostos, [...] ele seria a faculdade de manter unido o sentido (Sinn $=$ o sentido) consciente que capta e recorta precisamente os objetos e a matéria prima $($ Bild $=$ a imagem) que emana do fundo do inconsciente (DURAND, 1988, p. 61).

Para tanto, nesta classificação a função simbólica se mescla com a função estética, pois nas duas funções a atuação do sujeito é individual.

Outros autores como Bürdeck (2006) e Schneider (2010) fazem classificações muito semelhantes a Löbach, nas quais elucidam que os objetos têm funções práticas ou de uso; falam das funções da percepção enquanto experiência individual do sujeito com o objeto; e outras que tratam dos significados. Contudo, a noção de símbolo apresentada por esses dois autores trata do símbolo semiótico, que determina, por pacto coletivo ou conversão, o objeto enquanto signo. Portanto, ele se dá no meio social, cultural e coletivo.

Sabemos que toda categorização corre o risco de se tornar problemática no sentido de vir a ser idealizada e simplificadora. Contudo, achamos por bem observar e ressaltar que, nessas classificações, as funções apresentadas são estreitamente relacionadas entre si, tanto no contexto em que se apresentam quanto no processo perceptivo do usuário, e que essas categorias são empregadas no sentido de "clarear" e nortear o entendimento do processo experiencial das relações entre sujeito e objeto.

Por uma questão metodológica, apresentaremos uma categorização própria das funções dos objetos, baseada nas considerações colocadas até aqui. Adotamos essa postura porque consideramos que as classificações apresentadas não explicitam suficientemente a abrangência que queremos destacar neste trabalho com relação às questões estéticas e simbólicas, e principalmente as emocionais, que tanto enfatizamos ao longo de nossa argumentação. As outras funções, as consideradas mais “objetivas” e mensuráveis, também terão espaço, contudo reservamos o direito de fazer uma descrição sintética, pois são discussões suficientemente debatidas na teoria e prática do design.

São elas: a) funções semissimbólicas; b) funções de uso; e c) funções técnicas. 


\section{a) Funções semissimbólicas}

Estas funções têm um sentido singular para nosso trabalho. Acreditamos que será por meio delas que encontraremos uma base conceitual para fundamentar nosso argumento: a experiência emocional gerada na relação entre o indivíduo e os objetos.

Para melhor explicarmos a atitude conceitual adotada para as "funções semissimbólicas" dos objetos, achamos pertinente inicialmente pontuarmos certas posições teóricas acerca do símbolo. Primeiramente faremos uma descrição sucinta das definições de alguns autores para depois discutirmos e relacionarmos à nossa proposição.

Etimologicamente, a palavra "símbolo" vem do grego sum + ballo, que significa "colocar junto, sinal de reconhecimento"; associar uma coisa com a outra. Do latim, adaptado do grego, significa symbolum, "marca distintiva, insígnia”, segundo Alleau (1976).

É a partir da filosofia de Kant que o símbolo adquire um valor estético. O autor estabelece uma ligação entre a natureza, realidade sensível, e o domínio da liberdade e moralidade. Em Crítica da Faculdade do Juízo, cita “o belo é o símbolo do moralmentebom" (KANT, 2002, p. 197). A natureza, enquanto conjunto de objetos que podem ser belos e produzir prazer estético desinteressado, transforma-se em símbolo de moralidade. Para o autor, a vivência estética é singular por ser pura e desinteressada, mas também, o sentimento de respeito pela lei moral deve ser puro e não subordinado por interesses. Assim, o símbolo de Kant é uma tradução, intuitivamente, das "ideias estéticas", não só das “ideias da razão".

Em Goethe (1749-1832), temos o símbolo romântico, que alcança tanto a dimensão perceptiva quanto a dimensão intelectualizada, mas também induz a um trabalho de interpretação infinita. Nesta vertente, o símbolo pertence ao domínio do indizível e leva a um empenho infinito de interpretação. Cavalcanti (2005, p. 281) diz que "é próprio da imagem simbólica [de Goethe] captar vivamente um fenômeno particular, de modo que recebemos, na observação, ao mesmo tempo o conteúdo singular e algo além dele, criando na imagem uma série de plano ativo de significação".

Em Cassirer (1874-1945), o conceito de símbolo se desloca para as ciências sociais e filosofia da cultura. O autor define o homem enquanto ser cultural que vive num mundo no qual linguagem, mito, arte e religião são aquilo que tece a teia simbólica da experiência humana. 
Na psicanálise, os símbolos são considerados, especialmente os oníricos, como uma ferramenta natural de defesa do homem, cujo conhecimento é indispensável para desvendar o inconsciente individual, em Freud, ou coletivo, em Jung. Em Durand (1988) e Jung (2008), o símbolo é considerado produto da obra e imaginação humana, com função criadora e poética para educar o homem (pelo rito e mito) às realidades invisíveis. Jung diz que usamos os símbolos para representar conceitos que não podemos nem definir nem compreender totalmente, pois muitas vezes as coisas se situam além dos limites do entendimento humano (grifo nosso).

Numa abordagem antropológica, os símbolos assumem duas perspectivas: a imagética - que aborda as contradições na construção das imagens simbólicas sem alusão à subjetividade -, e a reflexiva - que tenta agregar as informações advindas da atividade do sujeito humano. Seguindo essa abordagem, Ricoeur (1913-2005) desmembra as perspectivas imagética e reflexiva, e diz que o símbolo tem tripla função: a) cósmica (relativa ao mundo sensível); b) onírica (relativa aos sonhos); e c) poética (quando o símbolo apela à linguagem), (RICOEUR apud CORREIA, 1999). Nesta última, por meio da metáfora e narrativa, há um desdobramento no campo referencial, uma segunda extensão diferente do referencial imediato, empregada com muita frequência pelo design.

Na semiótica, em Peirce (1839-1914), o símbolo não é completamente arbitrário, ele "extrai em seu poder de representação porque é portador de uma lei que, por convenção ou pacto coletivo, determina que aquele signo represente seu objeto" (PEIRCE apud SANTAELLA, 1983, p. 91). Portanto, o símbolo em Pierce se refere àquele no qual há um "pacto coletivo" quanto ao seu significado, não permitindo generalizações individuais ou naturais, pois, caso contrário, não seria símbolo, e sim, ícone ou índice. Em Saussure (1988), há o estabelecimento da distinção entre símbolo e signo linguístico: este une um conceito (significado) a uma imagem acústica (significante) de modo arbitrário. O símbolo, em oposição, tem por qualidade um elemento inicial de conexão natural entre significante e significado.

Seguindo a tradição da linguística proposta por Saussure, e depois por Greimas e Floch (MACEDO, 2008) há três tipos de linguagem segundo a natureza da relação entre significado e significante, ou plano do conteúdo e plano da expressão: ${ }^{12}$ a) os

${ }^{12}$ Hjelmslev (1899-1965), seguidor da linha saussureana, substituiu os termos significante e significado de Saussure por plano da expressão e plano do conteúdo, respectivamente. O plano da expressão é aquele em que as qualidades sensíveis são selecionadas entre si por traços diferenciais (cor, forma, 
sistemas simbólicos - linguagens em que os dois planos estão em conformidade total, a exemplo do símbolo de Pierce; b) os sistemas semióticos - não há conformidade entre os dois planos; e c) os sistemas semissimbólicos - são caracterizados pela conformidade não entre elementos isolados, mas entre categorias dos planos da expressão e do significado. Aqui, as categorias são entendidas como conjuntos de elementos comparáveis entre si.

Floch desenvolveu um princípio de análise na semiótica discursiva, chamado semiótica plástica, cujo conceito fundamental se baseia no estatuto do texto, seja em quaisquer de suas manifestações - objeto, pintura, fotografia, marca, cartaz. Nessa proposta a análise é dada entre os elementos estruturais do plano do conteúdo e da expressão que estão reciprocamente relacionados com a semântica e a sintaxe.

Numa relação de polaridade e dentro de uma estrutura de componentes conceituais de sintagma e paradigma, o conjunto paradigma possui relações entre o plano da expressão e do conteúdo, formando assim relações em polaridades, essenciais dentro do sistema semissimbólico.

Após esse breve apanhado sobre algumas posturas assumidas acerca do símbolo e das relações simbólicas, podemos enfim explanar sobre a função semissimbólica dos objetos aqui entendida.

Já de início, explicitamos que ao longo do texto nossa posição poderá parecer tanto quanto ambígua, contudo, frente ao mundo complexo no qual as relações dualistas ou impositivamente restritas e fechadas se desfazem, acreditamos ser um caminho.

Partindo da premissa de que é por meio das formas, cores, texturas, sons que os objetos são dados ao mundo, e aludindo a Maturana (2001), que considera os objetos, assim como o homem, pertencentes ao mundo humano, consideramos junto a Kant que os objetos pertencem tanto ao plano intelectualizado quanto a uma vivência estética singular, pura e desinteressada.

Acenando agora sobre as colocações de cunho romântico de Goethe, temos o símbolo que alcança a dimensão perceptiva e a dimensão intelectualizada de Kant, mas igualmente suscita uma dimensão de interpretação infinita. Por serem manipulados pelo indivíduo, os objetos são propensos a um entendimento de conteúdo singular e alguma coisa além dele, acionando um dispositivo que cria na imagem uma série de aberturas ao processo de significação, pois vem de uma interpretação particular do indivíduo.

textura, entre outros). No plano do conteúdo, a significação vem dos traços diferenciais advindos da cultura, que, em sua leitura do mundo, ordena e encadeia ideias e narrativas. 
Por pertencer ao plano do indizível, o símbolo de Goethe nos remete às concepções psicanalíticas de Durand e Jung, sobre as quais Jung diz que usamos os símbolos para representar conceitos que não podemos determinar tampouco alcançar totalmente, pois algumas vezes os acontecimentos se situam além dos limites do nosso entendimento.

Para tanto, entendemos a função semissimbólica dos objetos como aquela que surge do indivíduo, de sua experiência subjetiva, pois, ao vivermos num mundo de imagens, não se trata de as considerarmos como verdadeiras ou falsas, mas de percebermos e sentirmos como essas imagens incidem e acontecem em nós. Atualmente, devido aos novos processos tecnológicos, os objetos podem ser produzidos em série limitada ou até em série exclusiva e, portanto, serem individualizados ou personalizados; ainda assim, os indivíduos vivem em sociedade e são determinados culturalmente. Por isso, nos referimos também ao contexto sociológico do símbolo proposto por Cassirer, pois acreditamos que, além das características "indizíveis" dos símbolos enquanto advindas das experiências particulares dos indivíduos, os objetos possuem aquelas que são convencionadas por regras culturais e sociais, nos levando, então, ao símbolo de Pierce.

Sabemos de antemão que o símbolo psicanalista não sugere uma relação de causa e efeito, pois ela define o símbolo como uma formulação de uma coisa relativamente desconhecida. Já, o símbolo semiótico é dado pela semelhança ou descrição abreviada de uma coisa conhecida. Assim, o símbolo semiótico diverge do símbolo psicanalítico enquanto fonte de origem, contudo ambos dizem respeito à geração de significados.

Queiroz (2011) trabalha com o termo "funções estético-simbólicas". Diz que a função simbólica, assim como a função estética, oferece espaço para interpretações pessoais. Entretanto, é na função simbólica que as influências do contexto sociocultural acontecem, porque está diretamente vinculada aos códigos estabelecidos em um grupo ou sociedade. Ou seja, apesar de unir os conceitos em um termo só, a autora separa conceitualmente as duas dimensões, pois para ela enquanto a função estética é particular, individual, a função simbólica é regida pelo coletivo, que é convencionado.

Quando dissemos anteriormente que nossa construção do pensamento poderia parecer ambígua, era exatamente neste ponto que queríamos chegar.

De um lado, o conhecido (símbolo semiótico); do outro, o desconhecido (símbolo psicanalítico). De um lado, o indivíduo (símbolo romântico); de outro, o coletivo (símbolo sociológico). Para nós, então, o que vem a ser função semissimbólica dos objetos? 
Admitimos, apesar da ambiguidade, que consideramos todas essas colocações. Propomos adotar o termo de semissímbolo de Floch. Como já vimos, é uma estrutura que trabalha com os planos da expressão (significante) e do conteúdo (significado) numa relação de polaridade, dentro de uma estrutura de componentes conceituais de sintagma e paradigma. Contudo, acrescentamos nessa estrutura uma proposta de abertura tanto de significado (estrutura do paradigma) quanto do significante (estrutura do sintagma). Consoantes a Jung, acreditamos que a experiência simbólica vem do indivíduo, do particular, do nível subjetivo, do inconsciente. Assim, a nuvem no céu não só pode significar chuva, como também leveza, maciez, algodão ou mistério, medo; pois nos remete a uma experiência subjetiva de como e pelo o que ela é, nos remetendo, assim, ao eixo das escolhas, o paradigma. Outra característica do eixo paradigmático é sua relação com o eixo de sintagma. As relações são dependentes do contexto que se apresenta.

Ou seja, aquela nuvem, naquele céu, naquela tarde, para aquele indivíduo, pode até significar chuva, mas certamente significará muito mais que chuva!

Deste modo, podemos dizer que as funções semissimbólicas dos objetos encontram-se diretamente vinculadas às associações simbólicas e afetivas, no nível subjetivo e intersubjetivo. Assim, como o contexto contribui para a significação dos objetos, qualquer variação dele altera o significado desses. Partindo-se desse entendimento, o objeto pode ser compreendido como um processo contextual dinâmico, uma realidade significante, uma linguagem, diretamente vinculado ao repertório simbólico e à percepção das pessoas.

A memória de emoções (afeto e emoções), o mundo vivenciado (sentidos), os sentimentos (valoração das emoções) e as experiências relacionadas a outros objetos já percebidos no decorrer da existência das pessoas (memórias) se tornam agentes influenciadores e de juízo do processo de percepção dos objetos.

Corroborando nosso pensamento, Bourdieu (1983, p. 120-121) $)^{13}$ analisa que, do ponto de vista semântico, os objetos podem ser entendidos como formas carregadas de características simbólicas dentro de um contexto social, cultural e cognitivo. Conforme afirma, "ainda que se manifeste como universal, a disposição estética se enraíza nas condições de existências particulares”. Por esse viés, a função semissimbólica de um objeto supera a noção de movimento ou estilo, compreendendo o significado dos

${ }^{13}$ Os símbolos para Bourdieu, afirmam-se, na noção de prática, como os instrumentos por excelência de integração social, tornando possível a reprodução da ordem estabelecida. 
objetos para os observadores e usuários, e o conteúdo simbólico embutido no universo individual e cultural deles.

Nessa mesma lógica, se poderia dizer então que a proposta de uma "estética universal" seria impositiva, pois estaria desprezando as diferenças de percepção de significados. Significados que até mesmo podem ser opostos e refletir valores e experiências diversas entre os diferentes indivíduos e grupos sociais. Desta maneira, por exemplo, o que seria repugnante para alguns, pode ser interessante para outros; bonito para uma determinada classe social pode ser feio para outra; o que é vulgar para uma, sofisticado para outra, e assim por diante.

No design, o processo de relação entre as pessoas e os objetos deve então resultar da incorporação dos aspectos da percepção individual e dos aspectos sociais e culturais.

Para Baxter (1998, p. 47), que utiliza o conceito de símbolo semiótico pierceano, um produto auxilia na construção da imagem do usuário perante o outro e desperta confiança na medida em que reflete a "autoimagem do consumidor". Outra questão colocada pelo autor é que mesmo antes de o consumidor ter tido a chance de examinar o funcionamento efetivo do produto, a "aparência visual do produto [...] construída pela incorporação do estilo de vida, valores de grupos e emoções" auxilia a transmitir a impressão sobre o aspecto prático-funcional e de desempenho.

Atualmente, com o comércio do mundo globalizado, a função semissimbólica tem influenciado sobremaneira o grau de consumo dos produtos, sendo muitas vezes, como disseram Norman (2006) e Löbach (2002), aquela que determina a compra. Um objeto, além de chamar a atenção por sua função de uso ou função estética, pode tornarse "desejável" por "prometer" experiências, fazendo com que as pessoas venham a adquiri-lo. Podemos destacar, então, a importância da capacidade criativa (imaginação) e de inovação no desenvolvimento de objetos, levando-se em conta o contexto em que se inserem e os significados que tomam para as pessoas.

É nesse sentido que defendemos que o designer deve projetar sob a perspectiva de realidades subjetivas, as dele e as dos indivíduos.

Assim como Beccari (2012, p. 255), tomamos como referência o conceito de exotopia ou excedente de visão de Bakhtin (1992) para definir a posição do designer enquanto sujeito criador. Bakhtin defende que o sujeito criador deve ver a si próprio e ao mundo numa posição de fronteira e com certo distanciamento: "quando contemplo um homem situado fora de mim e à minha frente, nossos horizontes concretos, tais 
como são efetivamente vividos por nós dois, não coincidem" (1992, p.43). Ou seja, o designer enquanto autor deve ser autoral, desde que tudo aquilo que lhe é seu, seja compartilhado. Agindo assim, ele constrói uma atitude de reciprocidade entre o designer (autor), o usuário (leitor) e a função semissimbólica, e as outras funções (conteúdo). Segundo Bakhtin, existe um autor-pessoa e um autor-criador presentes no sujeito criativo. O primeiro é o sujeito criador em si, aquele que está contido em si mesmo. Já o autor-criador é aquele que separa e delimita suas experiências subjetivas com o intuito de estabelecer uma experiência nova, não mais individual. A posição do autor-criador é como uma segunda voz que direciona e parte do indivíduo criativo no intuito de articular as experiências, pressupondo como elas podem ser manifestadas e como podem ser direcionadas em um sentido comum dentro de um contexto de olhares socialmente delimitado.

Com a capacidade de discernir a relação entre sua própria subjetividade (autorpessoa) e sua relação com a intersubjetividade (o autor-criador), o designer terá um processo de criação que dele não resultará um objeto finalizado, autônomo em si mesmo, mas um objeto "aberto", com grandes possibilidades em atender a função semissimbólica e ser um objeto emocional.

A função semissimbólica dos objetos está diretamente atrelada à percepção das formas, à aparência visual, à percepção das cores e texturas, às experiências estéticas, às associações afetivas e emocionais, às questões subjetivas e intersubjetivas das partes envolvidas e, além disso, a um determinado contexto. Um exemplo banal, mas extremamente expressivo, é a diversidade de significados, percepção e de preferências de certas cores para determinados indivíduos e culturas.

Krippendorff (1996, p. 161) sustenta que "uma coisa, além de precisar ter forma para ser vista, precisa fazer sentido para ser compreendida e utilizada". Ou seja, para o autor, as formas devem ser definidas a partir questões como percepção, referências culturais e os modos de representação do sujeito e coletividades, que por sua vez, também variam conforme as experiências e a natureza simbólica de cada um.

Assim, podemos dizer que a função semissimbólica pode ser alterada entre os indivíduos e as culturas quanto ao significado e as associações atribuídas. Como exemplo, os móveis do estilo rococó do século XVIII, considerados como detentores de excesso de elementos decorativos que representavam o poder, a prosperidade e o despojamento de seus proprietários (RYBCZYNSKI, 1999). 
A relação da forma com o conteúdo dos objetos, especialmente na configuração dos móveis, sofre influência direta das alterações que ocorrem nas relações do indivíduo na família e na sociedade (esse assunto será mais bem comentado no capítulo 3). As máquinas de costura Singer, por exemplo, que entraram no mercado como produtos de função "técnica" ou "mecânica" em meados do século XIX, assumem um papel fundamental na decoração do lar enquanto mobília. Heskett analisa:

Sua primeira máquina, de 1851, era um mecanismo muito simples e funcional, mas uma análise sobre a importância da aparência levou ao revestimento do mecanismo com metal laqueado, decorado com motivos florais. O banco e o pedal, produzidos como itens opcionais, também tinham motivos em espirais e rendilhados, desenhados para torná-los mais aceitáveis num ambiente doméstico. A forma básica das máquinas de Singer era ditada pela função mecânica, mas a apresentação se adequava a concepções do que era esteticamente apropriado ao contexto social no qual as máquinas eram utilizadas (HESKETT, 1997, p. 57-58).

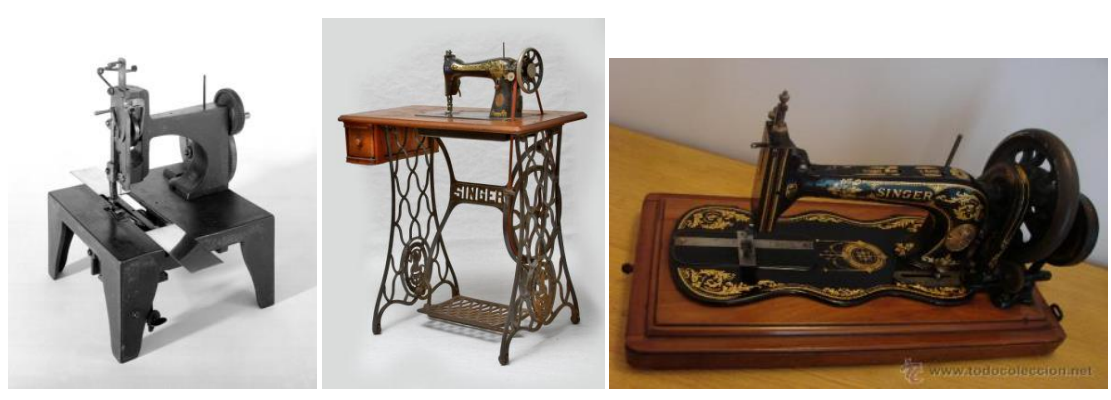

Figura 12 - Máquinas de costura Singer, 1851. Estrutura e pés (1890) e detalhe da decoração

Outra questão importante foi a influência significativa das transformações sociais relacionadas à questão de gênero no desenvolvimento dos móveis. Como exemplifica Rybczynski (1999), durante o século XVIII, novos tipos de móveis foram projetados exclusivamente para as mulheres quando passaram a participar mais ativamente da vida social e cultural, como as chaises longues.

Por isso que, mais uma vez, defendemos que o designer deve saber articular a sua individualidade com as individualidades das pessoas, num processo intersubjetivo, e a partir daí propor "aberturas" às experiências simbólicas e, porque não dizer, às experiências emocionais. 
Historicamente podemos detectar vários exemplos que evidenciam a importância da função semissimbólica para os indivíduos. Por vezes, algumas características formais ou elementos relativos ao funcionamento e uso dos produtos tiveram de ser acrescentados (ou retirados) aos produtos como resposta à resistência dos consumidores e usuários com relação às inovações. Heskett cita o exemplo do tanque de combustível falso das motocicletas Ariel "Leader":

A motocicleta "Leader" Ariel, por exemplo, produzida na Inglaterra em 1957, tinha um tanque de combustível localizado no quadro traseiro, mas conservava um tanque falso de forma convencional. Esse mesmo estratagema foi repetido mais tarde na japonesa "Asa de Ouro 1000 " da Honda, com o tanque falso abrindo-se ao meio para revelar controles elétricos. Em ambos os casos, os produtores não se sentiram capazes de apresentar uma escolha visual aos consumidores em face do poder da imagem convencional de uma motocicleta, muito embora sua forma tivesse se tornado funcionalmente redundante (HESKETT, 1997, p. 183).

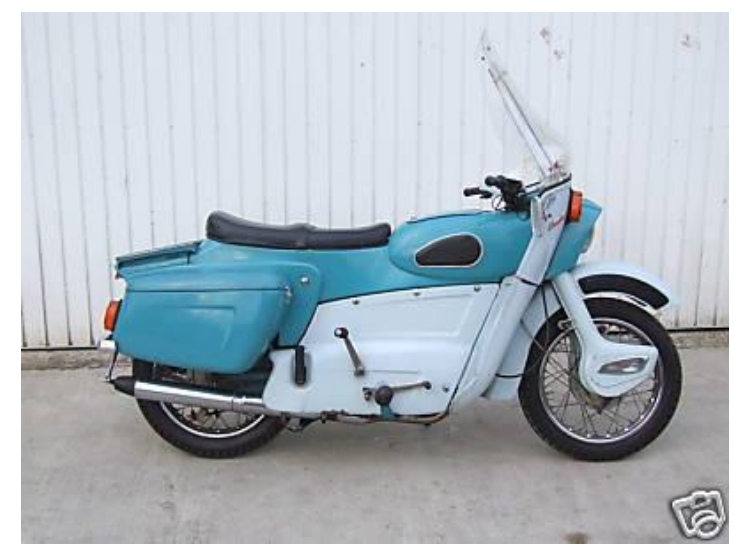

Figura 13 - Motocicleta “Ariel Leader" (1957)

Para tanto, entende-se que a dinâmica dos indivíduos e sociedades é condição que permeia a função semissimbólica dos objetos. Assim, o designer deve procurar exprimir, nos seus mais variados suportes, os significados particulares e socais, sempre mantendo uma relação dialógica entre o nível subjetivo e intersubjetivo, e saber que os objetos geram significados com possibilidades infinitas para cada indivíduo.

Para um melhor entendimento das funções semissimbólicas e do papel do designer no desenvolvimento dos objetos, é fundamental assinalar a distinção entre a dimensão de significação e sua legitimação, seja no contexto da produção ou no do 
consumo dos objetos. Será por meio da função semissimbólica que a dimensão emocional da relação entre indivíduo e objeto será efetivada.

\section{b) Funções Práticas ou de Uso}

As funções de uso são aquelas que se relacionam à execução da tarefa ou ação propriamente dita. Caracterizam-se por aquilo que o usuário espera do produto no que tange ao seu "funcionamento". Usualmente são categorizadas em funções principais (ou básicas) e secundárias, em que as primeiras caracterizam as principais finalidades do produto, e as últimas auxiliam no desempenho da função principal. Uma cadeira, por exemplo, possui como função básica ou principal "assentar" ou "acomodar" um indivíduo com conforto, mas também pode oferecer como função secundária ao conforto um mecanismo que permita, ao usuário, uma variação no ângulo do encosto. Isso demonstra que tanto as funções básicas quanto as secundárias são muito interligadas para a boa execução da função prática.

Essas funções traduzem mais facilmente as características objetivas e mensuráveis, como defende Schneider (2010). Conforme Löbach (2000), elas dizem respeito ao nível orgânico-corporal, isto é, fisiológico. Compreendem, por exemplo, as questões ergonômicas, de manipulação e uso direto dos objetos.

Para Iida (1990), a adaptação antropométrica, a facilidade de manuseio, a segurança, o fornecimento claro de informações, entre outros, são fatores que convergem para a adaptação ergonômica qualitativa de um produto ao ser humano.

As cadeiras do Rococó são exemplo do desenvolvimento e aperfeiçoamento da ergonomia. Essas peças demonstram a preocupação com o conforto no uso dos móveis, por meio da adequação dimensional exigida na época, e pela busca do uso correto do estofamento (esse assunto será mais bem discutido no capítulo 3). Nota-se que a criação desses móveis, tratando-se das funções de uso, também era influenciada por questões culturais e sociais, pois de acordo com Rybczynski (1999, p. 107), “os sofás eram largos não para servir a diversas pessoas, mas para permitir os gestos largos, as pernas puxadas para cima, o braço caído para trás, e para as roupas volumosas da época". Vê-se aqui claramente a relação entre as funções práticas ou de uso e as semissimbólicas.

Essas duas funções estão altamente relacionadas, pois as funções de uso também podem propiciar experiências até então desconhecidas. Como afirma Ferrara (1986, p. 120), “o uso resiste a uma síntese que é operação cabível no mundo linear, 
lógico, sequencial; ao contrário, o uso é feito de lampejos e intuições que não se encadeiam numa relação de antecedente e consequente, causa e efeito, condição e condicionado".

Essa função nos remete ao design comportamental de Norman (2006). Pois é nela que há a compreensão do objeto, por meio de feedbacks entre a(s) operação(ões) e a apreensão do uso.

Há vários exemplos que salientam o estreito vínculo existente entre as funções de uso e as funções semissimbólicas

No design de móveis, um exemplo bastante curioso, está presente nas diferenças culturais e caracterização de uso dos produtos na ação de "sentar". Por terem o costume de sentarem-se junto ao chão, chamado "seiza", os japoneses utilizam mesas que possuem pernas mais curtas em relação ao modelo ocidental.

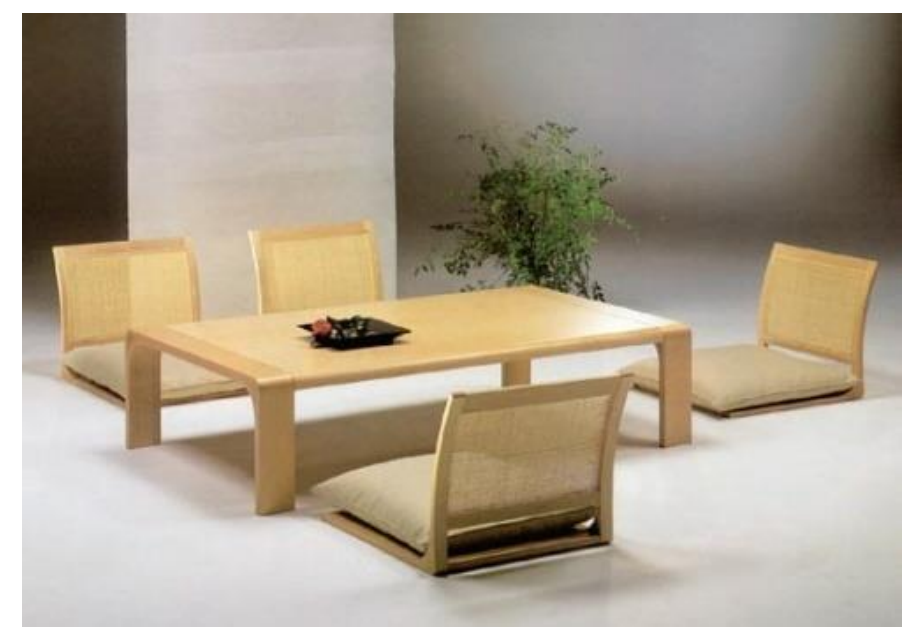

Figura 14 - Conjunto de mesa e cadeiras Saisu Chairs

No Brasil temos infinitos exemplos que ilustram a necessidade de se adequar as funções de uso aos contextos nos quais se inserem os produtos. Em fins da década de 1990, quando do lançamento do veículo modelo "Gol Bola", a empresa Volkswagen foi obrigada a fazer modificações nas engrenagens dos espelhos laterais dos carros para melhor adaptação à estatura e aos limites visuais dos brasileiros.

Assim, chegamos à necessidade de considerar as particularidades que se encontram nos diversos contextos - cultural, social e econômico - com relação às questões que regem as funções de uso dos objetos. Um produto pode ser apropriado para um indivíduo, e inapropriado para outro; adequado para um grupo social, mas inadequado para outro. Há de se considerar a dinâmica das transformações do indivíduo 
e da sociedade, que certamente afetam indireta ou diretamente a configuração física dos objetos e espaços.

\section{c) Funções Técnicas}

Como citado anteriormente, as funções dos produtos são estreitamente relacionadas entre si, tanto no universo perceptivo do usuário quanto no universo contextual em que se encontram.

Segundo Ono (2004, p. 77), as funções técnicas “compreendem os princípios e elementos de construção de um objeto, e seu cumprimento depende diretamente, dentre outros fatores, da qualidade dos materiais e componentes e dos recursos tecnológicos empregados pelas empresas". Aqui a autora vincula os pressupostos técnicos como dependentes dos "recursos tecnológicos".

Para nossa definição, consideraremos como sendo propriamente técnicos, aqueles que englobam a feitura em si, com ou sem desenvolvimento tecnológico. Ou seja, em se tratando de funções técnicas, podemos dizer que são aquelas que fazem o produto "funcionar".

Para Iida (1990), característica técnica de um produto:

[...] é a parte que faz funcionar o produto, do ponto de vista mecânico, elétrico, eletrônico ou químico, transformando uma forma de energia em outra, ou realizando funções como cortes, soldas, dobragens e outras. Dentro da qualidade técnica, deve-se considerar a eficiência com que o produto executa a função, o rendimento na conversão de energia, a ausência de ruídos e vibrações, a facilidade de limpeza e manutenção, e assim por diante. (IIDA, 1990, p. 354)

As funções técnicas assumem uma condição "sine qua non" para a venda de um produto. Nenhuma pessoa compra um produto que "funcione" ou execute suas funções técnicas "mais ou menos". O botão de liga-desliga deve responder como o esperado; o acabamento de uma mesa de madeira não pode conter farpas ou ser mal lixado; ou as portas de um armário e suas dobradiças devem abrir e fechar com eficiência. A função técnica está para o programa, para o planejado, e por isso não admite possibilidades.

É fundamental que os produtos cumpram suas funções técnicas adequadamente, caso contrário não atenderiam às necessidades básicas a que se propõem e que desencadeiam a compra. Contudo, cabe considerar que com os novos mercados e as novas demandas e necessidades, a execução de tais funções é indispensável. Existem 
produtos concorrentes, entretanto, que possuem a mesma função e também oferecem funções adicionais, as consideradas secundárias, que podem decidir o investimento.

As soluções técnicas devem igualmente atender à conjuntura local, como normas, clima e requisitos de segurança, bem como aos requisitos culturais das pessoas, que têm diferentes ajuizamentos, dependendo do contexto.

Norman (2006) diz que existem muitos objetos mal resolvidos tecnicamente que se tornam problema, e não solução. Flusser (2007) também coaduna com esse pensamento e observa que os objetos são "obstáculos culturais" que, por vezes, podem adotar funções contraditórias; servem tanto para remover entraves quanto para virarem obstáculos nas tarefas e nas relações que se estabelecem entre sujeito e objeto.

Para tanto, a criação dos objetos estabelece uma postura não reducionista diante da complexa e crescente tecitura do mundo atual. $\mathrm{O}$ entendimento dos requisitos projetuais ou das funções semissimbólicas, de uso e técnicas, é de fundamental importância, pois delas vêm a responsabilidade nas decisões de projeto e as consequências que esses objetos terão na cultura material e na vida das pessoas.

A dimensão emocional até aqui discutida está profundamente arraigada nas relações entre as funções que os objetos assumem perante os indivíduos. O design, enquanto design dessas relações, deve apresentar uma dialética que inquiete os sentidos, a vivência, as experiências e, sobretudo, que invente lugares para essa inquietude. 


\section{OBJETOS EMOCIONAIS}

Quando o objeto não é mais especificado por sua função, é qualificado pelo indivíduo. (BAUDRILLARD, 1993, p. 94)

Ao deixar o nomadismo, o homem começou a construir objetos que passaram a fazer parte do cotidiano e a auxiliá-lo na execução de diversas tarefas diárias ou eventuais. Com o pensar e o fazer, esses objetos tornaram-se cada vez mais complexos e sofisticados ao longo de seu desenvolvimento técnico e histórico.

Nesse processo, os objetos foram adquirindo novos elementos que vão além das funções utilitárias: elementos simbólicos que se relacionam com o espaço afetivo do usuário. São objetos particularizados, que satisfazem aos anseios dos indivíduos, das mais variadas naturezas: as coroas de reis e rainhas como objetos que simbolizam poder; a caneta Montblanc falsificada do tio, que foi a pessoa mais importante na vida daquele sobrinho; os móveis da avó, que tanto lembram a infância; o meu relógio Swatch que não funciona, mas continua guardado em minha gaveta como se fosse uma joia, pois ele possui uma forma que me agrada profundamente; ou a fantasia do Homem Aranha do meu filho, que, com 8 anos de idade, insiste em se tornar o super-herói numa fantasia favorita (dentre tantas outras existentes), de tamanho reduzido para sua idade.

Buscamos entender, então, o que vem a ser um objeto cujas características emocionais e afetivas dos indivíduos são a base para seu projeto, para que ele seja elemento de comunicação na formação de nossas relações sociais.

Para Moles, "etimologicamente objectum significa atirar contra, coisas existentes fora de nós mesmos, coisas colocadas adiante, com um caráter material: tudo o que se oferece à vista e afeta os sentidos" (LAROUSSE apud MOLES, 1981, p. 25). Já projeto significa projectum, lançado adiante. Assim, projeto e objeto possuem etimologias próximas e complementares.

Segundo Moles, o conceito de objeto ultrapassa sua definição etimológica, pois é a partir do momento em que se insere nas referências sociais de nossa sociedade que ele se conforma como tal

O objeto, dentro de nossa civilização, é artificial. Não se falará de uma pedra, de uma rã ou de uma árvore como um objeto, mas como uma coisa. A pedra só se tornará objeto quando promovido a peso de 
papéis, e quando munida de uma etiqueta: preço..., qualidade..., inserindo-a no universo de referências sociais (MOLES, 1981, p. 26).

Isso faz com que o caráter natural do objeto seja retirado e o configure como produto. Entretanto, o objeto assume outros aspectos que o tornam mais importante para o ser humano. Assume a função de mediador entre o homem e o ambiente.

[...] mediador universal, revelador da sociedade na progressiva desnaturalização desta, construtor do ambiente cotidiano, sistema de comunicação social, carregado de valores como nunca no passado (MOLES, 1981, p. 8).

Moles (1981) e McLuhan (1999) afirmam que o objeto inicialmente é um prolongamento do ato do ser humano, "esse visivelmente surge - é um primeiro sentido - como mediador entre homem e o mundo" (MOLES, 1981, p. 10-11).

Para pensarmos nas relações emocionais com os objetos, é necessário compreender o sentido social, cultural e comunicativo deles, e que também ultrapassemos os preceitos postulados pela produção industrial. Em cada um desses contextos, os objetos adquirem novas simbologias sintetizadas em um espaço interno. Assim, enquanto signos interpretáveis, ou símbolos que levem a experiências simbólicas, os objetos ganham uma característica particular conforme seu usuário.

Baudrillard (1993), ao fazer uma análise do objeto nas sociedades tradicionais, nas quais a ordem fundamental é a Natureza enquanto substância original, da qual provém o valor, diz que a relação de comunicação apresentada no objeto tem um caráter importante por representar a comunicação do homem como meio, pela relação de interno e externo. Nesse sentido, objeto seria entendido como

[...] figurante humilde e receptivo, esta espécie de escravo psicológico e de confidente tal como foi vivido na cotidianidade tradicional e ilustrado em toda a arte ocidental até os nossos dias, tal objeto refletiu uma ordem total ligada a uma concepção bem definida do cenário e da perspectiva, da substância e da forma. Segundo essa concepção, sua forma é a demarcação absoluta entre interior e exterior, é continente fixo, o interior é substância (BAUDRILLARD, 1993, p. 33).

Numa condição subjetiva, os objetos possuem a característica de conter dentro de si várias informações sobre o sujeito; por meio do olhar do próprio sujeito, sugerem um sentido simbólico e significados que levam a uma relação de despertamento 
emocional e afetivo. Já numa relação intersubjetiva, os objetos recebem, armazenam e geram diversas características do indivíduo, do tempo, da sociedade e da cultura. Os objetos precisam sempre de um olhar, de um sentir de alguém, de um indivíduo que os revele e lhes dê sentido. Por conseguinte, os objetos se tornam depósitos de impressões, individuais ou coletivos, com sobreposições "virtuais" em função dos vários olhares e usos.

Para defender nossa visão sobre a relação dos objetos com os seus usuários e a experiência emocional que surge dessa relação, a tigela com forma de gato (figura 15) é um exemplo. Em princípio, é um objeto que deve armazenar e conter um líquido (função prática ou de uso). Quem na realidade usa e adora (love) o objeto são os donos dos "gatinhos". É uma tigela destinada a conter leite para ser acrescido de cereais, biscoitos, dentre outros alimentos, não para os gatos, mas para seus donos ${ }^{14}$. A forma interna propõe uma surpresa. A tigela é constituída de sulcos indefinidos em seu interior que, num primeiro momento, não possuem um significado claro, apenas causam certa estranheza e curiosidade, pois são estruturas que, em princípio não deveriam existir. As suas dimensões e material - aproximadamente $14 \mathrm{~cm}$ de diâmetro, $8 \mathrm{~cm}$ de altura, e cerâmica - supostamente suportariam a estrutura física da tigela. Mas, devido a formação dos tais sulcos, à medida que o leite é depositado, uma carismática imagem de um gato vai surgindo de modo crescente por meio do contraste do líquido branco no recipiente de cor amarela. É como se o dono visse o seu animal também crescendo, evoluindo da forma de filhote à fase adulta em alguns segundos. Independentemente, se é um filhote ou se é um animal adulto, seu dono certamente suscitará imagens e memórias, e experienciará emoções e sentimentos, seja pela metáfora do tempo, seja pela graciosa imagem do felino.

${ }^{14}$ Disponível em: <http://www.respeitoaosanimais.com.br/tigela-para-gatos/>. Acesso em: jan. 2015. 


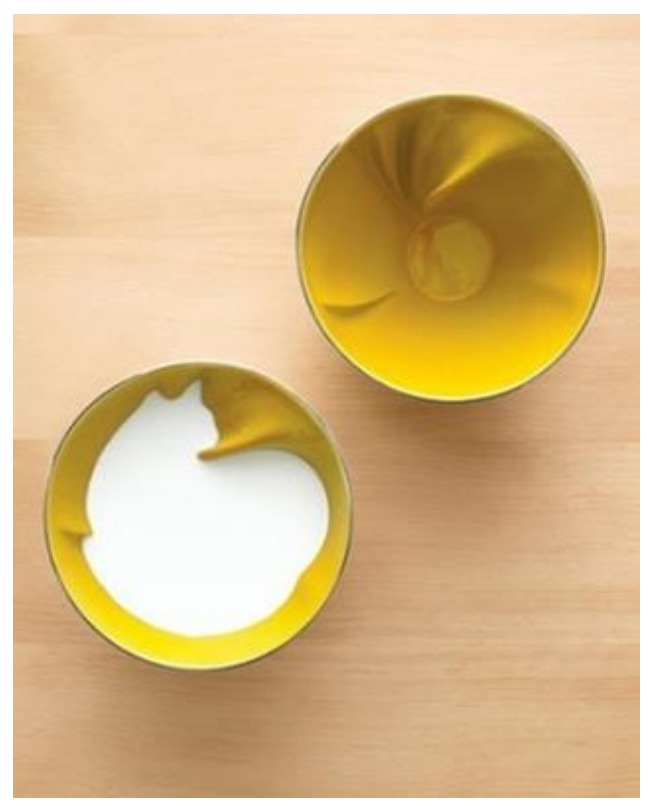

Figura 15 - Bowlcom forma de gato. Autor desconhecido.

O objeto é capaz de evidenciar a Natureza e a cultura dentro de seus espaços, considerado, assim, um elemento que consegue ultrapassar a barreira do tempo e que carrega consigo a história da cultura material humana.

Os objetos emocionais são aqueles que enquanto "objetos não funcionais" ou “discurso subjetivo", são "singulares, barrocos, folclóricos, exóticos, antigos”. Objetos que contradizem as exigências da avaliação funcional para responderem a um propósito de outra ordem: nostalgia, evasão, testemunho, lembrança, memória (BAUDRILLARD, 1993, p. 81). São nesses objetos que se encontra uma pretensa sobrevivência da ordem tradicional e simbólica.

Eles têm a capacidade de ser aqueles que formam, no meio privado, uma esfera ainda mais privada. São objetos que propiciam ao indivíduo uma evasão da cotidianidade, pois lhe proporcionam momentos íntimos e de refúgio. Poderíamos deferir aos objetos emocionais,

[...] ele não é nem verdadeiro, nem falso, é perfeito - não é interior, nem exterior, é um álibi - não é sincrônico nem diacrônico (não se insere nem em uma estrutura ambiente nem em uma temporal), é anacrônico - não é, em relação àquele que o possui, nem atributo de um verbo ser, nem objeto de um verbo ter, mas concerne na verdade à categoria gramatical do objeto interno, que declina quase tautologicamente a substância do verbo (BAUDRILLARD, 1993, p. 34-35). 
Entendemos os objetos emocionais como aqueles que possuem distintas manifestações elaboradas de maneira simbólica, sejam estas individuais ou coletivas. Deste modo, compreendemos que a história particular de um sujeito pode ser concebida por meio de suas relações com os objetos e mais, observamos como essa experiência pode operar sobre o objeto a ponto de, muitas vezes, torná-lo quase um "ser".

Objetos que se tornam "seres", porém seres afetivamente tranquilizadores, pois abrandam o indivíduo ao invés de restringi-lo. "Objetos-seres", ou retornando à Le Courbusier (1996), "objetos-sentimento ou objetos-vida", cuja coexistência se torna viável, pois suas divergências ou diferenças não causam conflito, como numa relação entre os seres vivos, mas se dirigem ao indivíduo, tornando-se um verdadeiro espelho: revelam imagens latentes e desejadas que permitem o reconhecimento do próprio indivíduo.

[...] o objeto é para o homem como uma espécie de cachorro insensível que recebe as carícias e as restitui à sua maneira, ou antes, as devolve como espelho fiel, não às imagens reais, mas às desejadas (RHEIMS apud BAUDRILLARD, 1993, p. 97).

Aos objetos emocionais são investidas e deslumbradas imagens, relações, emoções e sentimentos que o indivíduo carrega consigo, no seu mundo subjetivo e intersubjetivo. Desempenham um papel que regula e ajusta o nosso cotidiano, pois permitem uma troca e exaltam uma rica relação. Assim, também podemos considerá-los objetos com "alma", cujo investimento afetivo não é dado apenas ao corpo material, mas a um sentido ao qual o indivíduo constitui e reconstitui um mundo, uma totalidade afetiva e privada.

Portanto, quanto mais o processo de projeto de design acolher as demandas que referenciam a emoção e o sentimento como fator fundamental para promover a experiência emocional, mais simples e natural será a produção dos objetos emocionais.

Nos objetos emocionais, o que se pretende é que seja estabelecido um diálogo ativo entre objeto e indivíduo. Que seus atributos formais tenham a liberdade de indicar, questionar ou velar suas funções, e principalmente, "abrir" processos de significação nos quais os processos simbólicos adquirem um novo olhar.

São objetos que permitem o jogo do descobrimento, no qual o indivíduo assume um papel de fruidor, contemplador e mediador.

Bomfim e Rossi (1989, p. 23) dizem que a forma dada aos objetos não é mais uma "caixa transparente que informa sobre sua função, mas uma caixa preta, que 
contém, mas não revela o conteúdo". E esse conteúdo (os significados) será possibilitado e revelado mediante o processo de interação do objeto com o indivíduo.

Por muito tempo, os objetos eram e deveriam ser percebidos por meio de suas funções de uso. Contudo, elas não se encerram em si mesmas. O objeto e suas funções só se concretizam na presença do sujeito por meio do "olhar voltado para o objeto" (JEUDY, 1999, p. 09).

Didi-Huberman fala-nos sobre o paradoxo acerca daquilo que está sob os nossos olhos, entretanto longe da nossa visão, atribuindo o poder do olhar ao próprio olhado pelo olhante. Objetos emocionais são como aqueles aos quais Benjamin (1994) se refere de terem o poder de levantar os olhos: "Isto me olha", diz Didi-Huberman (1998, p. 148).

Assim, os objetos emocionais convergem para aquilo que Didi-Huberman denomina como objeto aurático:

[...] cuja aparição se desdobra, para além de sua própria visibilidade, o que devemos denominar de suas imagens, suas imagens em constelações ou em nuvens, que se impõem a nós como tantas outras figuras associadas, que surgem, se aproximam e se afastam para poetizar, trabalhar, abrir tanto o seu aspecto quanto a sua significação, para fazer delas uma obra do inconsciente" (DIDI-HUBERMAN, 1998, p. 149).

Encontramos muitos objetos emocionais em nosso cotidiano. Além dos já expostos, podemos citar a chaleira com apito cantante de Richard Sapper, da marca Alessi, que possui um bico de onde saem as notas musicais "mi" e "si" que, segundo Norman (2008), foram inspiradas pelo som dos vapores e barcaças que navegam pelo rio Reno. O logotipo da Google, que se expande com os "os" conforme o número de páginas encontradas nas buscas; ou as banais, porém divertidas caracterizações dos tipos, conforme a relevância do tema ou de datas comemorativas.

A poltrona Cadê, uma poltrona que se oculta num cubo preto e se mostra somente ao receber o corpo de quem nela se senta, é um exemplo de objeto que contradiz os preceitos da "forma segue a função" e apresenta uma proposta de mascarar o objeto, enquanto função primária. Faz uma voz contrária ao dogma funcionalista: a forma esconde a função. É um produto que confunde, mas instiga a nossa percepção, e faz com que nosso relacionamento com o objeto seja por meio de um processo que traz novas significações à medida que se experiencia. 

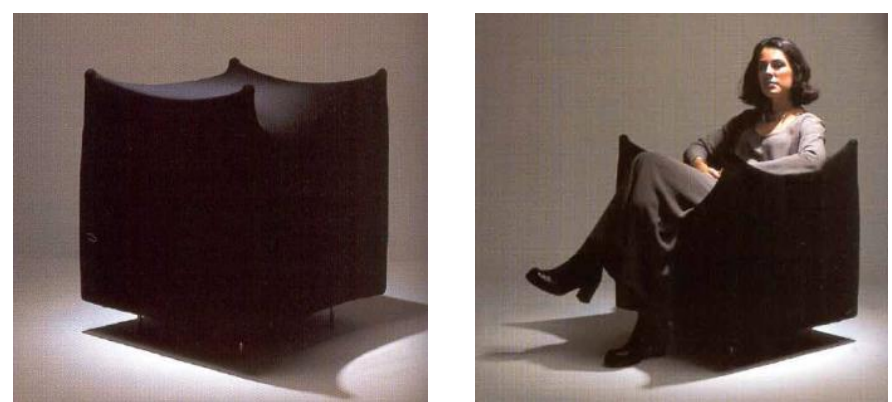

Figura 16 - Poltrona Cadê - de Luciana Martins e Gerson de Oliveira, 1995. Estrutura em vergalhão de aço, estrutura do assento e encosto em tramas de elástico e braços em espaguete de látex. Revestida com duas camadas de tecido elástico, que deslizam entre si

É nessa habilidade de oferecer mais do que somente a função de uso dos objetos, de se relacionar com nossa percepção e sentidos, de mexer com nossos parâmetros e critérios que esses objetos surgem. Isso não quer dizer que as funções de uso sejam necessariamente descartadas, elas simplesmente não são as únicas.

Assim, os objetos emocionais são aqueles que estão aptos a oferecer ressignificações e ressimbolizações ao longo do cotidiano imediato ou até da vida do sujeito: propõem estórias, permitem trocas, e que a história do sujeito seja contada por meio de suas relações.

\begin{tabular}{|c|c|c|c|}
\hline permitem trocas & \multicolumn{3}{|c|}{ qualificados pelo indivíduo } \\
\hline particularizados & & mediadores & \\
\hline \multicolumn{2}{|c|}{ depósitos de impressões } & álibis & \\
\hline \multicolumn{2}{|c|}{ anacrônicos } & objetos int & rnos \\
\hline \multicolumn{2}{|c|}{ objetos com alma } & dialógi & \\
\hline levantam os olhos & \multicolumn{3}{|c|}{ permitem ressignificações } \\
\hline \multicolumn{2}{|c|}{ permitem ressimbolização } & \multicolumn{2}{|c|}{ permitem a fruição } \\
\hline propõem estórias & \multicolumn{2}{|c|}{ contam histórias } & \\
\hline
\end{tabular}

Figura 17 - Conceitos proeminentes dos objetos emocionais

Desse modo, para concluirmos as proposições colocadas nessa primeira parte do trabalho, podemos dizer que as características dos produtos geram reações emocionais. Por suas características "objetivas", os objetos estimulam os sentidos; pelas "subjetivas", significam, e, por sua vez, estímulos e significados produzem emoções e sentimentos. 
PARTE II - O DESIGN DE MOBÍLIA: EM BUSCA DE REFERÊNCIAS SIMBÓLICAS E EMOCIONAIS

De origem latina, a palavra MÓVEL - mobilis -, que significa essencialmente o que é móvel, aquilo que se move, foi incorporada ao vocabulário português de uso comum desde o século XIV. Já mobília - denominação feminina para o termo - é equivalente a mobiliário. Esses termos começam a ser utilizados para denominar o conjunto de móveis que surge dentro da moradia a partir do século XIX. Na etimologia, os verbetes móbil; mobi.liar; -lia; -liário; -lidade; -lização; -lizar resultam em um único vocábulo: MOVER, que significa exercer movimento com, deslocar, comunicar movimento a.

As palavras francesa e italiana para mobília - mobiliers e mobília significam, como a palavra portuguesa, "o que pode ser movido" (este sentido não existe na palavra inglesa - furniture) (RYBCZYNSKI, 1999, p. 40).

Para Moutinho (1999), trata-se de denominação comum a qualquer peça para equipar uma casa, construída na dimensão do homem e que possa proporcionar-lhe bem-estar e postura adequada no trabalho, no repouso e no convívio. Já para Corona e Lemos (1972), o significado mais comumente aplicado na contemporaneidade é: objetos móveis para uso ou adorno de uma casa.

Para Rocha (s.d.), o cofre é o móvel primeiro, primitivo, que exprime a ascendência do termo em todas as acepções originárias. Artefato inicial próprio da evolução do homem e exemplar que permite o desdobramento nas demais formas e usos.

O cofre, com sua caixa a assentar diretamente sobre o solo, é o móvel primitivo - protótipo de todos os móveis utilitários, artísticos, de guardar e repousar. O móvel primitivo, nascido das necessidades mais rudimentares do homem - aquelas de guardar, de preservar, de proteger das intempéries e de defesa dos bens humanos -, deu origem a todos os outros, num ciclo de evolução que apresenta aspectos curiosos. É fácil imaginar a caixa de guardar, com seu próprio protetor, servindo também de assento, de leito e até de mesa. (ROCHA, s.d., p. 9) 
Interessante a analogia que Rocha faz do uso do cofre como aquilo que assenta ao chão e serve de apoio para outras atividades, como aquele artefato que guarda fortunas e relíquias íntimas, materiais ou simbólicas.

Independentemente de suas significações, fidedignas ou não do verdadeiro entendimento do termo, o fato é que o móvel tem seu conceito material totalmente compreendido na sociedade contemporânea. Enquanto signo de sociedades e culturas, constitui símbolo no meio social. Assim, na maioria das vezes, na associação frequente que se faz entre objeto e conceito, uma peça de mobiliário pode ser reconhecida por meio da leitura de seus tipos de uso ou de sua forma. É certo, entretanto, que todo contexto cultural constitui uma linguagem particular, considerada fundamental para $\mathrm{o}$ entendimento dos preceitos fundadores dos artefatos de sua sociedade.

Para tanto, se na parte I do trabalho, discutimos as condições que levam os objetos a serem considerados aqueles que também proporcionam relações emocionais, a esta parte é dedicada a um levantamento eminentemente histórico e de caráter quase didático acerca de duas questões consideradas fundamentais para nossa análise.

A primeira, descrita no capítulo 3 , diz respeito à abordagem sobre as interrelações da formação do espaço doméstico, enquanto influenciador do modo de morar, com a evolução do uso e da produção do mobiliário. Apresenta fatos pontuais que ocorreram em algumas sociedades do continente europeu e norte-americano durante a passagem dos séculos tidos como relevantes para o entendimento de nossa abordagem e destaca períodos em que os móveis ora eram utilizados como objetos de funções puramente práticas ou de uso, ora a eles eram agregadas funções de dimensões semissimbólicas. Aqui, o móvel será considerado como objeto em relação à casa, à vida doméstica - indivíduo e família - e aos comportamentos sociais e culturais.

Já a segunda questão, contida nos capítulos 4 e 5, está relacionada especificamente à história do móvel brasileiro, ao locus da pesquisa. Enquanto estudo do objeto "móvel" em si e suas características formais e estilísticas, abordamos suas origens, formação, influências e produção no Brasil.

Está dividida em três grupos. O primeiro, contido no capítulo 4, diz respeito ao mobiliário do Brasil pré-colonial e colonial: suas influências e referências; o segundo grupo é sobre a inserção do pensamento modernista na produção do mobiliário; e, por fim, o terceiro grupo fala do design de móveis contemporâneo, suas prerrogativas e proposições. Nos dois últimos grupos, contidos no capítulo 5, fazemos referência às singularidades de alguns designers que se destacam em suas linguagens e produção. 


\title{
3. O MÓVEL E A VIDA DOMÉSTICA
}

\author{
"A configuração do mobiliário é uma imagem fiel \\ das estruturas familiares e sociais de uma época"
}

(BAUDRILLARD, 1993, p. 21).

O surgimento, o desenvolvimento e as transformações do móvel enquanto artefato de apoio às atividades e aspirações humanas estão atrelados às transformações da sociedade, refletindo-se em diversas situações, atitudes e comportamentos. A transformação da habitação e do espaço é determinada pelos aspectos econômicos, sociais e culturais pelos quais o homem atravessa; e o mobiliário é também resultado e reflexo dessas alterações. Ele se torna um depósito de impressões em que ficaram gravados as necessidades, as expressões artísticas e o desenvolvimento da técnica.

Observa-se que a vida do homem transcorre nos espaços interiores a maior parte do tempo. Esses espaços mantêm uma forte relação com seus usuários e são portadores de estabilidade, permanência e continuidade.

A função básica de uma casa é a de ser abrigo. Para o homem, a preocupação primeira sempre foi estabelecer fronteiras simbólicas ou reais na habitação e proteger-se contra o externo: perigos humanos ou animais, naturais ou sobrenaturais, (SCHIMIDT, 1974). Para Lemos (1989), o sentido de proteção física e simbólica ocorre porquanto a casa é tida como um invólucro seletivo e corretivo das manifestações climáticas, bem como oferece as mais variadas possibilidades de proteção.

Segundo Boyle (1993, p. 78), ao descrever a volta de Ulisses para casa depois de quase 20 anos da guerra de Troia, Homero registra atitudes em que se observam impressões muito semelhantes à noção de lar experimentada nos dias de hoje. Trata-se de um lugar no qual a identidade moral e a identidade social dos indivíduos estão intensamente ligadas numa experiência universal do lar; um lugar que cada um trata como "profundo e inquestionavelmente seu".

Desse modo, os móveis e suas configurações enquanto mobília e mobiliário são parte fundamental da situação que corroborou para a passagem do status de "espaços interiores", considerados abrigos e de proteção física, para "espaços simbólicos", símbolos dos indivíduos e de suas identidades. 
Na história universal há relatos de que é a partir do século III a.C. que o desenvolvimento da vida urbana na região mediterrânea introduziu melhoria significativa no espaço doméstico e as condições de vida se transformaram com a ascensão das cidades.

Sobre os móveis gregos, Oates (1991) diz que eram poucos: alguns bancos encostados na parede da sala, um ou outro móvel em algum aposento. $\mathrm{O}$ autor justifica esse fato ressaltando que o pensamento grego era prioritariamente político e social tratado fora de casa -, depois doméstico.

Com relação à configuração formal dos móveis, mesmo considerados como objetos utilitários e com certa escassez, seguiam os preceitos instituídos pela arte grega. A arte clássica e seus preceitos de belo clássico eram definidos com base em um ideal de perfeição, equilíbrio e harmonia que os artistas procuravam representar pela simetria e proporção. As formas humanas (as mais representadas) e as da natureza apresentavam-se como se fossem reais e, ao mesmo tempo, exemplares aprimorados. A natureza não deveria ser apenas copiada, mas aperfeiçoada. Na figura 18 podemos ver o uso da simetria e aplicação de detalhes de plantas e animais, e formas antropomórficas.

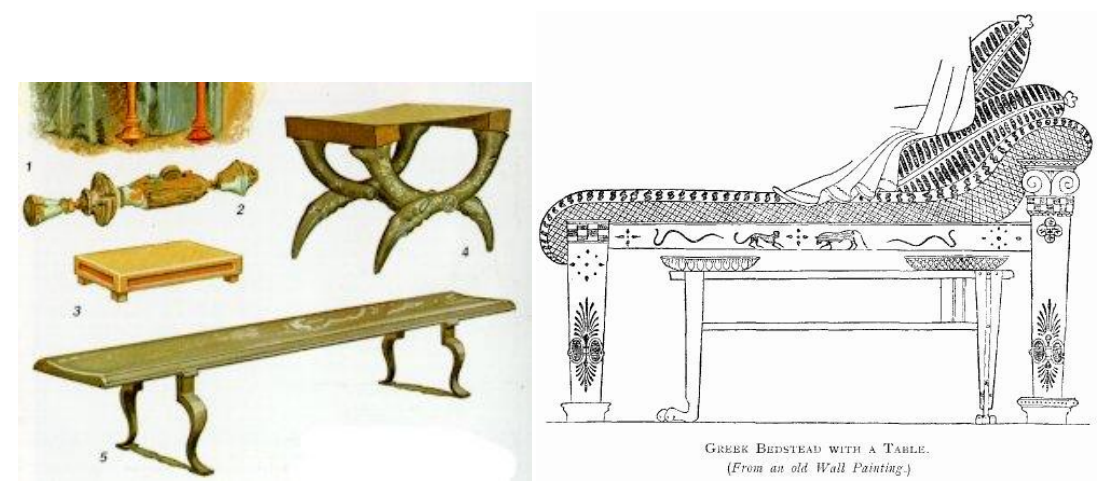

Figura 18. Exemplo da mobília grega. Formas com desenhos simétricos e proporcionalmente equilibrados

Em uma passagem sobre o emprego das artes na sociedade grega, Winckelmann relata:

É freqüente o uso dos monumentos uma vez que a arte conservasse toda sua grandeza. Consagradas unicamente às divindades e aos objetivos mais úteis da pátria, as produções de arte inspiravam ao povo uma espécie de respeito. A moderação e a sensatez reinavam nas moradas dos cidadãos, o artista não se via obrigado a baixar-se às minúcias para encher os ocos da casa de um rico [...]. Sabemos que Milcíades, Temísclotes, Aristides e Cimon, os chefes e libertadores da 
Grécia, não viviam em casas melhores que as de seus concidadãos. (WINCKELMANN, 2002, p. 115-116)

A ligação da arte à exaltação dos deuses e aos seus monumentos fazia da morada grega um lugar singelo, com moderação e sensatez. Contudo, é nesse ambiente que a arte vai desenvolver-se e se converter num dos pilares conceituais e estilísticos para a história da arte.

Durante os primeiros anos do século I a.C os centros urbanos do mundo grego foram romanizados, surgiram cidades e novos centros. Roma ampliou sua cidadania e se tornou o núcleo de uma nação e de um império. Na vida privada, as pessoas começaram a ver a casa como um bom lugar para passar o dia. A residência começava a atender a outras funções: assumia um papel de ostentação, mas igualmente era utilizada como um local para resolver assuntos de negócios.

Assim como nas casas gregas, as casas romanas possuíam pouca mobília, indicando ainda pouca relação de uso privado. Havia alguma variedade de bancos populares conhecidos como disphros, com quatro pernas reforçadas com tirantes, torneadas ou arqueadas, e tinham como acabamento final garras de animais e curvas côncavas ou convexas, como ilustrado na figura 18. Para o uso mais utilitário do cotidiano, os romanos usavam arcas reforçadas para todo o tipo de armazenagem. Os alimentos eram conservados em receptáculos e os pertences domésticos e individuais espelhos, joias, materiais de bordado, entre outros - eram depositados em pequenas caixas e cestos de vime. Diferentemente do interior grego, o interior romano já transparecia um maior uso social, adornado por estátuas, tapeçarias, pinturas murais coloridas, mosaicos, havendo relatos do uso de colorido panejamento como cortinas. A grande diferença entre a residência grega e a romana é que esta passa para o domínio privado. As questões do Estado afastaram-se da vida diária do cidadão comum e passaram a ser decididas pelo governo e por um serviço público, fora da residência. Então, é a partir da passagem do público para privado que há o início de uma relação mais direta entre o indivíduo e seus móveis.

A partir do século III d.C. dá-se a decadência do império romano. As guerras, as invasões bárbaras e o declínio na vida rural, com a evasão dos camponeses atrás de segurança nas cidades resguardadas por muralhas, fizeram com que as cidades romanas declinassem, e a alta qualidade da vida doméstica - conforto, lazer, artes decorativas, boa comida - também decaiu. 
O lar na Europa da Idade Média tomara outra dimensão: as pessoas contentavam-se em ter casa, comida e roupas, e em criar filhos que tomassem conta delas na velhice. Eram dois níveis de civilização justapostos - um primitivo e précristão e o outro mais recente, cortês e religioso.

Segundo Boyle (1993), a maioria das casas dos camponeses possuía um único cômodo e a janela era um buraco na parede. A entrada era coberta por uma cortina de couro e o piso de terra batida era assentado por junco. Usavam um círculo de pedras com função de lareira no centro do aposento. Nessas condições, os móveis resumiam-se a meros apoios para as atividades: eram bancos e uma tábua apoiada em cavaletes, todos fabricados com improvisação e falta de materiais, cumprindo de maneira rude apenas a função utilitária.

Já entre os séculos XI e XIV houve o crescimento da população europeia, a agricultura começou a se expandir devido às condições climáticas. Com a ativação do comércio surgiram novos grupos urbanos e, em razão disso, a melhoria da qualidade de vida. De acordo com Rybczynski (1999), em relação à casa pouca coisa se modificou. Apesar dos progressos concernentes ao aquecimento e à luz, a classe menos abastada ainda não morava bem, não tinha água ou saneamento e praticamente não possuía móveis ou objetos pessoais.

No período medieval, grande parte da população era miserável e não compartilhava da prosperidade. No alto da estrutura estavam os senhores feudais, e o poder era baseado na posse e na defesa das terras. À Igreja cabia abrigar a autoridade espiritual, centralizada na paróquia, e administrar as terras de sua propriedade.

Oates (1991) salienta que os senhores, que moravam em castelos medievais, eram continuamente forçados a deslocar-se para administrar suas posses em áreas despovoadas na Europa. Nesse sentido, o mobiliário precisava atender a duas funções distintas: a primeira era ser muito pesado e robusto, a fim de evitar furtos pelos próprios moradores do castelo; a segunda era ser desmontável, para que pudesse ser transportado com facilidade até outra casa do mesmo proprietário.

Os castelos, além de possuir esses móveis com fim específico, eram abarrotados de outros objetos de uso pessoal e coletivo. Tudo era acondicionado nesses móveis para transporte, e essa função de uso foi o grande requisito que orientou a concepção do mobiliário daquela época e até hoje é usada como referência. "Os meubles, a palavra francesa para móveis é uma reminiscência desse tempo; ela quer dizer isso mesmo, algo transportável” (OATES, 1991, p. 38). 


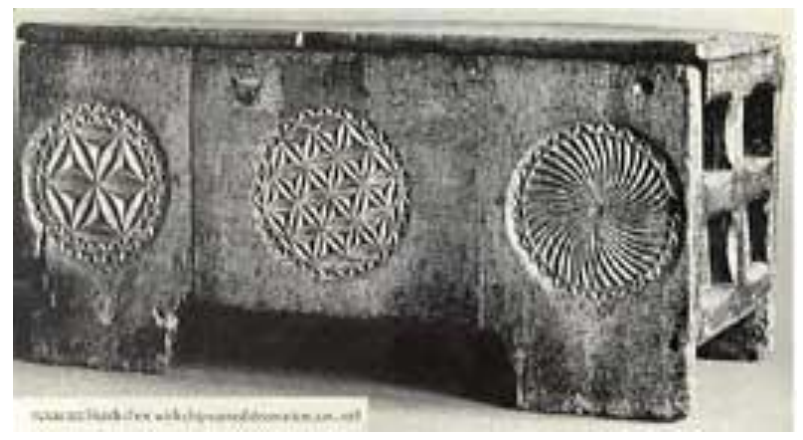

Figura 19 - Arca Hulch-chest - período medieval

Nota-se, na figura 19, a estrutura frontal dividida em três partes planas e chapadas com simbologia que diz respeito às castas dos senhores feudais, e a lateral da peça com aberturas que, provavelmente, tanto facilitavam o manuseio para o transporte quanto para sua montagem e desmontagem.

Contudo, havia outra classe que fazia parte do sistema medieval. Uma classe que usufruía do crescimento e se diferenciava do restante da população medieval: os moradores das cidades. Segundo Rybczynski (1999), a cidade foi uma das invenções mais importantes da Idade Média; ela era separada do campo, sendo seus habitantes os burgueses.

A importância dessa classe medieval é que o burguês vivia em uma casa. A aristocracia vivia num castelo protegido; o clérigo, num mosteiro; e o servo, num casebre. Esse fato é de extrema importância para a questão da (re)invenção da domesticidade. Esta casa burguesa no século XIV servia como moradia e como local de trabalho; a casa medieval era um lugar público, e não privado, como afirma Forty:

Antes, a maior parte da produção e do comércio era realizada nas residências dos artesãos, comerciantes ou profissionais envolvidos, e compreendia-se a casa como um lugar que incorporava trabalho às atividades habituais de morar, comer, dormir e assim por diante. (FORTY, 2007, p. 137)

Ou seja, diferentemente das casas romanas, as medievais assumiam novamente a função pública.

Pela - e apesar da - multiplicidade de funções, as casas medievais eram simples e havia escassez de móveis. Seus habitantes ficavam mais alojados que propriamente moravam. Apesar de não se locomoverem como os senhores feudais, os burgueses do 
mesmo modo precisavam de móveis desmontáveis e multifuncionais para que os ambientes se adaptassem às diferentes funções a que deveriam atender. As funções dos espaços eram conformadas mudando-se ou desmontando-se os móveis segundo surgiam as necessidades. Apesar de o conceito de "multifuncionalidade" haver sido criado apenas em meados do século XX, nesse período esses "artefatos móveis" já cumpriam tal função.

Avalia-se aqui que as funções práticas ou de uso eram as que se sobressaíam, pois esses móveis eram tratados mais como equipamentos do que como posses de estima ou de contemplação. O principal objetivo era adaptarem-se a diferentes ambientes e a diferentes funções de uso, possibilitando ao cômodo que se transformasse em sala de jantar ou local de trabalho do artesão. A tábua era montada sobre o cavalete e virava mesa, ou essa mesma tábua transformava-se em base para colocar colchões, modificando esse ambiente de sala para quarto de dormir.

A ausência da divisão entre trabalho intelectual e trabalho manual na produção dos objetos de uso é a principal característica dessa época. O artesão era aquele que possuía todas as informações necessárias para o planejamento e a produção dos objetos: da escolha da matéria-prima, das possibilidades de acabamento, das "instruções" de uso às resoluções formais. Algumas das informações eram apreendidas junto à comunidade, aos usuários, ou provinham da própria habilidade do artesão. De maneira muito implícita, por meio da prática orientada pela tradição, a produção dos objetos dependia da experiência (maestria) do artesão.

Tendo como premissa que o papel concernente à arte era o da ilustração ou representação como esforço visual das verdades anunciadas, o artesão criava sob regras muito rigorosas, que definiam tanto a temática da obra quanto sua realização concreta. A “expressão" do artesão era tão indesejável como desnecessária; os modos artísticos deviam formar um conjunto harmônico e não se podia inovar ou romper com os padrões vigentes. A habilidade do artesão não era obtida pela individualidade ou capacidade criadora de sua obra, mas decorria da servidão às normas e da capacidade de aplicá-las o mais integralmente possível.

Esse espírito foi predominante até o final da Idade Média, quando, na classificação das artes, a fabricação dos objetos de uso cabia a uma segunda categoria junto com escultura, tecelagem, marcenaria -, requerendo técnicas que objetivavam a satisfação de necessidades básicas. A relação entre homem e objeto utilitário visava 
prioritariamente à satisfação das necessidades práticas, e qualquer relação além dessa estética ou simbólica - decorria dessa função.
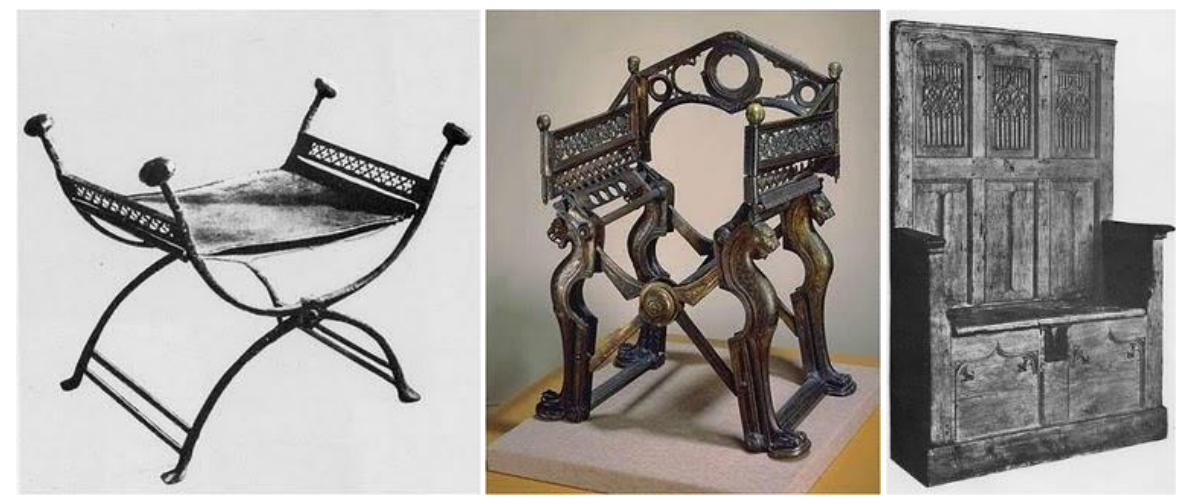

Figura 20. Faldistório; Trono de Dagoberto; Arca-banco - período medieval

Nesse período são encontradas cadeiras que tinham movimentos de abrir e fechar - movimento em $\mathrm{X}-$, o que demonstrava uma tendência à versatilidade e tentativa de dar maior mobilidade às peças. $\mathrm{O}$ faldistório, uma cadeira sem encosto, mais usada no ambiente religioso, e o trono de Dagoberto, fabricado em bronze e desmontável, ilustrados na figura 20, são exemplos desse tipo de estrutura. Já a arcabanco, de estrutura aparentemente mais rígida, era utilizada como um móvel multifuncional. Móveis de assento também serviam para guardar ou armazenar utensílios, assim como alguns modelos eram desmontáveis ou dobráveis, demonstrando a preocupação com a função de transporte.

Naturalmente que se está a tratar até agora dos objetos de uso, mas havia o artesanato dito "artístico", destinado ao clero e à nobreza, no qual as questões estéticas e simbólicas ganhavam importância, agindo como meios na diferenciação entre cotidiano e solenidade, entre profano e sagrado.

$\mathrm{Na}$ arquitetura e no mobiliário do alto clero e nobreza, pode-se encontrar certo equilíbrio entre as questões estéticas e simbólicas e aquelas ligadas ao utilitário ou uso. A pintura e escultura relacionavam-se à estética e ao simbolismo; a marcenaria e a alvenaria, à funcionalidade do espaço arquitetônico e ao uso prático dos objetos.

Nesse período, a Igreja e a nobreza dividiam o poder sobre as questões da matéria e do espírito. A imagem de Deus projetada nos homens, em seu trabalho e na própria natureza, era o que condicionava o "belo" na interpretação do medievo. O "belo" não estava sujeito às peculiaridades dos objetos, tampouco era resultante de um 
julgamento subjetivo. Vê-se aí uma contradição: como criações divinas, o homem e a natureza deveriam também ser belos e bons, assim poderiam servir como modelo para uma prática estética. Contudo, tanto a natureza quanto o homem (corpo) são apenas a parte visível da criação e estão em segundo plano, se comparados ao espírito. A alma é eterna; a matéria é mortal e não perfeita (BOMFIM, 1998).

A representação do mundo material da Idade Média adota o princípio da mimese platônica, ainda que a representação do homem e da natureza não tenha compromisso com o real, como na arte clássica dos gregos (BOMFIM, 1998).

À medida que as condições da vida doméstica começam a mudar, a casa burguesa torna-se mais privada. $\mathrm{O}$ desejo de maior privacidade foi fator que refletiu imediatamente no ambiente interno, e os cômodos se encheram de móveis mais bem acabados e mais bem adaptados às necessidades. A partir desse momento, sua importância muda e eles passam a significar mais do que simples objetos utilitários.

Segundo Oates (1991) e Argan (1992a), com o Renascimento italiano, no século $\mathrm{XV}$, surge o interesse pela arte e pela cultura clássica. Passa a existir o conceito de classicismo. Os artistas italianos queriam recuperar e fazer "renascer" os valores plásticos das artes dos antigos. Como dito anteriormente, o conceito de belo clássico era definido na arte grega com base em um ideal de perfeição, equilíbrio e harmonia que os artistas procuravam representar pela simetria e proporção. As formas humanas apresentavam-se como se fossem reais e, ao mesmo tempo, exemplares aprimorados. A natureza não deveria ser apenas copiada, mas aperfeiçoada.

Os italianos preferiam espaços elegantes e grandiosos, e os artistas eram os responsáveis pela concepção de suas residências. Arquitetos, pintores de afrescos e escultores dedicavam-se à criação e à decoração da nova casa. Considerado como arte menor ou arte utilitária, ao móvel ainda era dada pouca atenção, e mantinha certa rigidez medieval. À medida que a vida se tornava mais íntima e mais social, os móveis iam aumentando em número e também em diversificação. Esse fato pode ser observado principalmente em relação às cadeiras da época. 


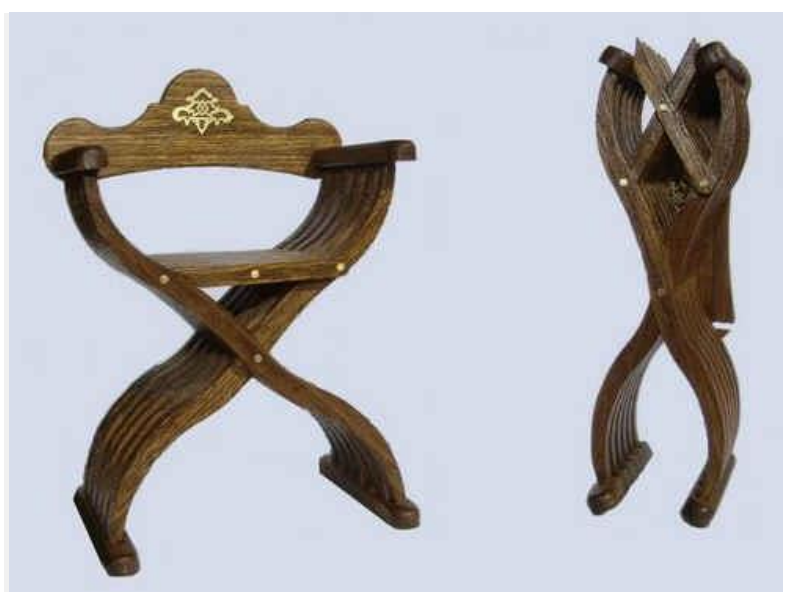

Figura 21 - Cadeira estilo renascentista Savonarola

As cadeiras em forma de $\mathrm{X}$ (movimento de abrir e fechar) eram simples e sobreviveram dos tempos medievais. A figura 21 ilustra as chamadas Savonarola, que apareceram no Renascimento italiano. Possuíam melhor acabamento que as medievais e eram decoradas com entalhes e marchetaria. Já a Sgabello, figura 22, outro tipo de cadeira leve e fácil de transportar se comparada às anteriores, apareceu nos fins do século XVI, como um estilo inédito à época. Era um banco de espaldar alto, reto e entalhado, e com assento estreito, características que dificilmente proporcionavam conforto. Nesse tipo de estrutura, destaca-se uma tentativa fabril de construção por encaixes móveis. Tanto os pés quanto o espaldar são encaixados sob e sobre o assento respectivamente, e podem ser desmontáveis.

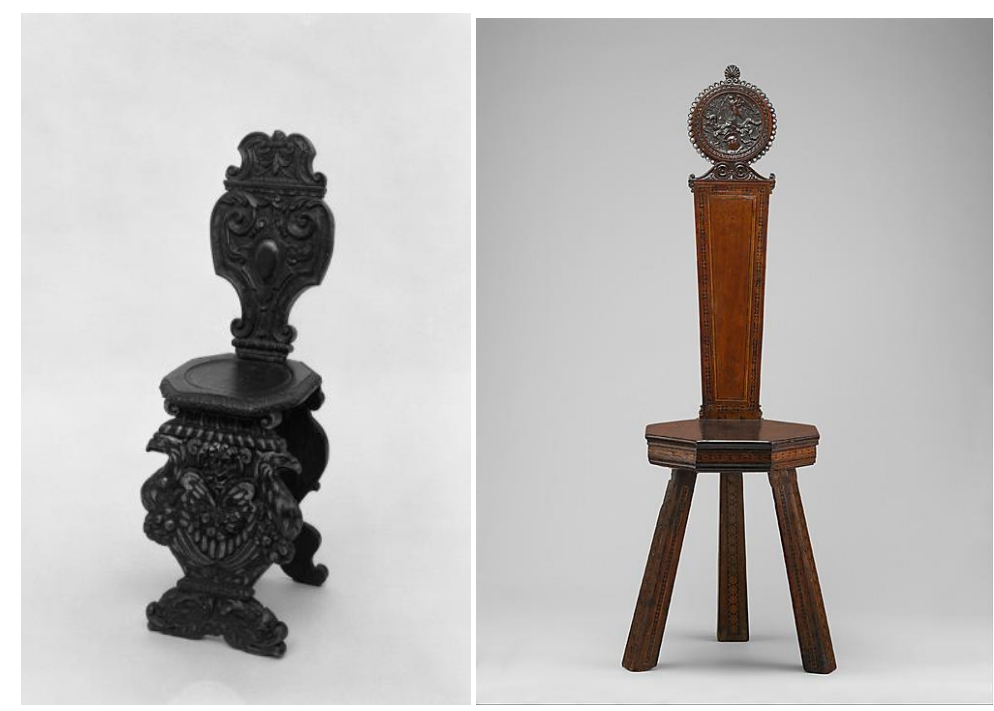

Figura 22 - Cadeiras estilo renascentista Sgabello 
Na França do século XVII, havia uma classe que vivia o conflito de estar entre a classe baixa miserável, da qual se distanciava, e a aristocracia, à qual invejava. Era uma sociedade que em vez da privacidade, priorizava as aparências. Os móveis para sentar estavam sendo produzidos com melhor acabamento, ganhando um ar de sofisticação e mais bem adaptados ao relaxamento. O vazio medieval havia sido preenchido com camas com dossel, cômodas e cadeiras.

$\mathrm{Na}$ Europa setentrional, mais especificamente na Holanda, surgiu o senso de intimidade percebido no ambiente. Essa característica dos interiores era pautada pela maneira como o aposento comunicava a personalidade de seu usuário, ou seja, a questão estética ou simbólica do ambiente era tão valorizada quanto os aspectos utilitários. Segundo Praz (apud Rybczynski, 1999), esse senso é designado como Stimmung. Essa característica muito nos importa, pois demonstra que quanto maior o grau de intimidade e privacidade dentro do lar, maior será a relação entre o indivíduo e seus objetos cotidianos.

Os holandeses eram caracterizados como uma sociedade urbana: moradores de cidades, que não eram aristocratas, nem camponeses. De acordo com Boyle (1993), formavam uma classe intermediária na sociedade composta por profissionais liberais, clérigos, mestres de escolas, mercadores, navegantes, especuladores do comércio exterior, entre outros.

A estrutura familiar começa a tomar outras dimensões. A presença das crianças, que agora são criadas diretamente por seus pais, e a ausência de criados nas modestas moradias burguesas incentivaram o surgimento da intimidade familiar.

Os móveis, enquanto participantes do contexto da habitação, assim como outros objetos utilitários, sempre foram parte integrante e suporte das transformações que aconteceram na interioridade privada, e como objetos produzidos pelo homem, representavam e representam o modo de pensar e agir do indivíduo e da sociedade, assim como o grau tecnológico ou o estado da arte.

\subsection{O mobiliário e suas relações: a domesticidade, a privacidade e o conforto}

Domesticidade, privacidade e conforto, o conceito de lar e da família: estas são, literalmente, as principais conquistas da Era Burguesa.

(LUKCAS apud RYBCZYNSKI, 1999, p. 63) 
Para Rybczynski (1999), o surgimento da vida doméstica está diretamente ligado à sociedade holandesa e à importância que se dava à família.

No cotidiano das famílias holandesas, a mulher era quem administrava o orçamento doméstico, enquanto o marido dedicava-se às questões do sustento da família. A tarefa mais importante da mulher era a conservação física da casa. Essa feminização do espaço foi muito expressiva no desenvolvimento do interior doméstico e, por conseguinte, na criação e produção dos objetos utilitários. Com a ausência de empregados, a mulher interferia diretamente na organização, evolução e modificação do espaço. A casa tornou-se mais íntima e, sob o controle feminino, a domesticidade surgiu como uma qualidade que não existia antes. Os primeiros testemunhos do novo estilo de móveis aparecem nas pinturas de interiores dos irmãos Vermeer, como mostra a figura 23.

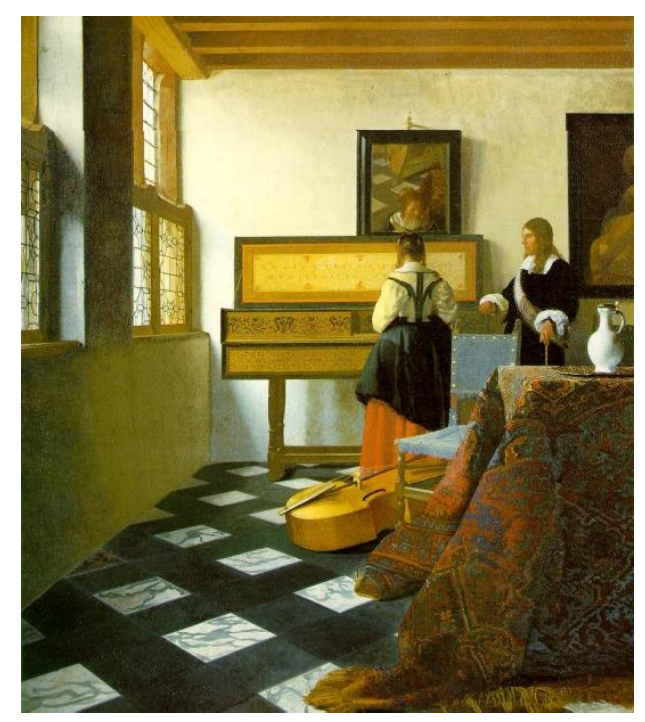

Figura 23 -The Music Lesson, c. 1662-65; Jan Vermeer. Óleo sobre tela, 74.6 x $64.1 \mathrm{~cm}$; Royal Collection, St. James Palace, London

O interior não era só um ambiente para as atividades domésticas como havia sido -, mas os cômodos, os seus objetos, agora adquiriam vida própria [...] Se a domesticidade foi uma das principais conquistas da Era Burguesa, ela foi acima de tudo uma conquista feminina. (RYBCZYNSKI, 1999, p. 48)

Para Forty (2007, p. 144), o conceito de feminização do lar era um lugar-comum na cultura anglo-saxônica: "As mulheres eram identificadas com a casa e se esperava 
que lidassem com a mobília doméstica, que se tornaria uma expressão de suas personalidades".

A partir de meados do século XVII, mesmo as sociedades mais austeras, como a holandesa, viram na França uma nova fonte de moda e estilo. Nesse período, a hegemonia cultural italiana começou a declinar e a França assumiu a posição de árbitro da elegância.

Ainda de acordo com Rybczynski (1999), no período governado por Luís XIV na França, a função do móvel consiste em realçar a arquitetura e não somente acomodar as pessoas. Em 1715, com a subida de Luís XV ao trono, as formalidades foram substituídas pela vivacidade, imponência, grandiosidade, intimidade e pompa, bem como pela fineza. O mobiliário produzido nessa época refletiu precisamente o que se pensava nesse período; era a expressão do que requeriam dele:

\footnotetext{
Sentar não era mais uma atividade ritualística ou funcional, mas se tornou uma maneira de estar à vontade. As pessoas sentavam-se juntas para ouvir música, para conversar, para jogar cartas. Um novo conceito de lazer ficou explícito [...] os encostos eram inclinados, em vez de verticais, os braços, curvos, ao invés de retos. Elas [as poltronas] eram mais largas e mais baixas e permitiam uma maior flexibilidade para acomodar o corpo. (RYBCZYNSKI, 1999, p. 94)
}

Vale realçar que nessa época a arte barroca já fazia parte do imaginário das pessoas. Em contraposição ao ideal clássico renascentista, as obras barrocas mostravam certa tendência ao assimétrico, ao extravagante, ao apelo emocional.

Ao propiciar a flexibilização dos cânones clássicos e atribuir à arte uma capacidade de persuasão inédita, o barroco dava ao artista uma liberdade de criar novas formas de representação. Por permitir uma "expressão mais flexível” do que aquela baseada em cânones prefixados, o barroco gera uma condição única na história da arte, permitindo assim a existência de uma série de variações nacionais.

Segundo Wöllflin (1984), o barroco é expressão de uma outra forma de ver o mundo, diferente da clássica. De acordo com esse autor, além das diferenças individuais e nacionais de cada artista, a arte barroca (arquitetura, escultura, desenho, pintura, e também a produção do mobiliário) possui características em que a forma é apreendida visualmente; a imagem é constituída por massas e a linha é desvalorizada enquanto elemento delimitador; as formas se fundem em movimento, sugerindo uma continuidade no espaço e no tempo; há a relevância do imaterial e incorpóreo; as sombras não aderem às formas e é dada pelo jogo de tons. Para Wöllflin, a arte barroca é a arte do parecer. 
A postura do homem barroco pode ser comparada à postura do homem emocional, aqui defendida em nossa proposta. Ele compreende a natureza ou o mundo, dados como infinitos em sua diversidade, e os interpreta partindo do princípio de que a aparência da realidade se sobrepõe à visão da beleza ideal canônica. Leva à valorização da representação com base na experiência e nas infinitas interpretações particulares dessas experiências. As coisas propõem uma apresentação que estimule ao homem representações de suas marcas do tempo, da forma como aparecem, da forma como são: suas memórias e suas experiências.

$\mathrm{Na}$ arte decorativa, da qual a produção do mobiliário faz parte, a composição cenográfica das figuras serve como recurso teatral ao propósito de convencer o espectador pela emoção.
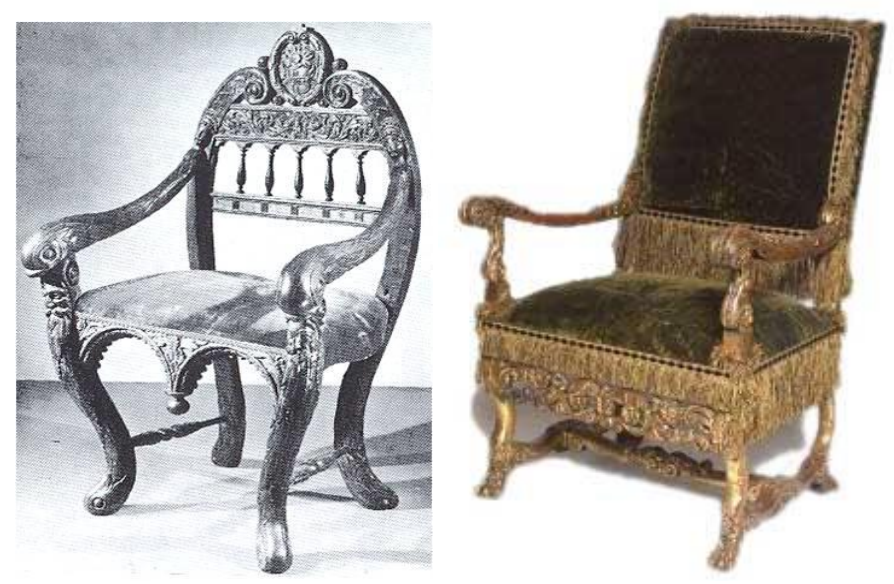

Figura 24 - Cadeira esculpida em carvalho com motivos marinhos; e Cadeira Luís XIV, 1675. Nogueira entalhada e dourada

Nas imagens da figura 24, podem-se constatar as principais características do barroco aplicadas ao mobiliário. Os estofamentos fixos tiveram um rápido crescimento na segunda metade do século XVII na França. Antes disso, eles eram feitos em almofadas soltas. As cadeiras do estilo Luís XIV do período barroco francês eram grandes e confortáveis, sendo geralmente estofadas no encosto, tendo o assento com tapeçaria, brocado ou com veludo enriquecido com bordados em ouro.

A composição formal é dada por "ondas sucessivas" que passam de detalhe a detalhe, fazendo com que a estrutura seja dada em um conjunto de formas não delimitadas. Sugere movimento, em contraste com a característica estática anterior. As formas do barroco dão a entender que a composição foi criada como se fosse um 
organismo e não apenas uma coisa fabricada: une o homem à natureza e à coisa artificial.

Durante a primeira metade do reinado de Luís XIV, as pernas das cadeiras eram retas. Posteriormente tornaram-se arredondadas ou mais "orgânicas", esculpidas com efeitos decorativos e ornamentais, incluindo representações de animais, como na cadeira da figura 24 , com motivos marinhos.

$\mathrm{Na}$ França, as classes abastadas queriam casas que expressassem seu gosto, e as residências do final do século XVII possuíam seu interior decorado de maneira a manifestar a pompa e a emoção.

Já no século XVIII, os espaços interiores e a decoração das casas refletiam uma característica diferente. Rybczynski (1999) afirma que havia nesse período uma grande variedade de móveis e uma diferença entre a mobília fixa e a mobília móvel. Isso era reflexo da especialização decorrente da divisão das casas em diferentes cômodos destinados a diferentes funções. Os novos cômodos foram decorados com um estilo que ficou conhecido como rococó. ${ }^{15}$ Os adornos, os rocailles combinavam-se aos arabescos, que possuíam linhas sinuosas em forma de "c" e "s". As composições tinham os motivos inspirados na natureza: pássaros; pequenos animais; flores e plantas; água, que se mesclavam com a sinuosidade das linhas e eram realizadas com muita liberdade e fantasia.

Em termos de espaço de construção, os ornamentos desse estilo foram usados somente como decoração dos interiores domésticos, em contraponto à "simplicidade" das fachadas externas dos edifícios. O rococó realçava o interior das casas e fazia uma clara distinção entre decoração de interiores (o interno) e de arquitetura (externo). Era nos interiores que as modas e as maneiras cotidianas, ligadas a uma "sociabilidade elegante" encontrada nos salões literários e artísticos, aconteciam. Nesses salões se encontravam a polidez e a performance social, e junto a essas, o luxo e o refinamento.

15 Rococó: esta palavra era um trocadilho com a palavra barroco; "roc" derivou de rocaille, que significava trabalho com conchas ou pedrinhas, um motivo característico. RYBCZYNSKI (1999). 


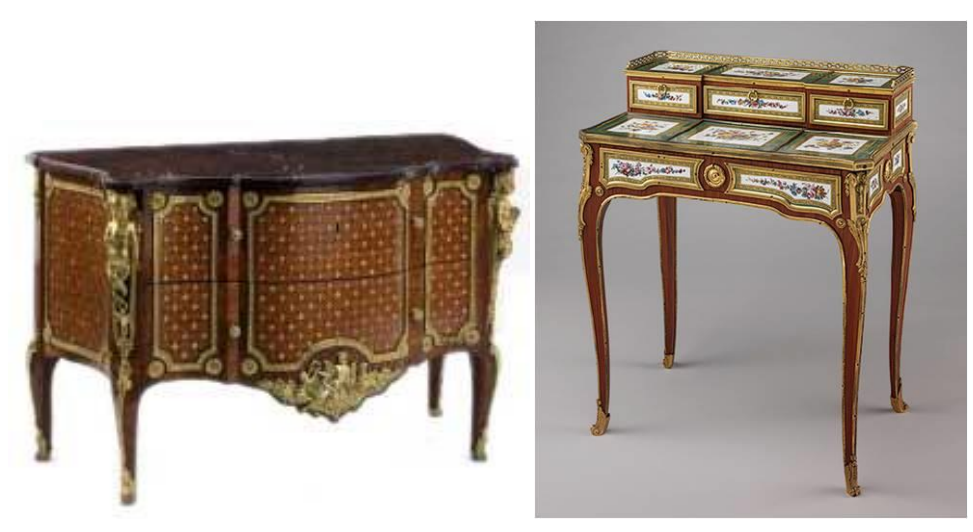

Figura 25 - Cômoda, 1774; Escrivaninha, móvel com gavetas e compartimentos, 1768 - estilo rococó

A figura 25 mostra duas peças em estilo rococó. A primeira possui aplicação em marchetaria sobre carvalho, com montagens em bronze dourado e tampo em mármore vermelho. A segunda, uma escrivaninha, com aplicação de adornos em motivos florais. Nota-se, nas duas imagens, a presença de formas mais esguias e delicadas, como as pernas curvas. Assim como os cômodos das residências começaram a ser divididos por funções específicas, os móveis também foram desenvolvidos segundo esse preceito. Começaram a surgir peças com elevado número de compartimentos, gavetas e portas.

O grau de liberdade conferido aos artistas do barroco possibilitou, ao mesmo tempo, uma especialização e estudos mais concretos nos móveis do período. Em especial pelo estilo rococó, que permitiu que questões relacionadas ao conforto fossem resolvidas, principalmente no tocante às cadeiras. Os marceneiros de período resolveram problemas com relação à postura, utilizando estudos sobre as posições do sentar e aprimorando, de modo empírico, o conforto.

As cadeiras eram confortáveis porque acomodavam a estrutura biológica, mas também porque acomodavam as posturas da época. A cadeira era um objeto decorativo que convidava a sentar, mas dava tanto prazer aos olhos quanto às nádegas. (RYBCZYNSKI, 1999, p. 109)

É a partir desse período, então, que podemos conferir aos móveis uma posição mais clara com relação às funções enquanto objetos utilitários, de funções práticas ou de uso, e objetos simbólicos, enquanto funções semissimbólicas.

Em uma de suas passagens, Rybczynski (1999) faz uma ponderação sobre o artificialismo da cultura humana, pois os prazeres não só como culinária, pintura e música, mas também os móveis, seriam caprichos materiais e artificiais. Observa, 
contudo, que: "Os móveis forçam a civilização que senta no alto a mais cedo ou mais tarde, levar em consideração a questão do conforto" (RYBCZYNSKI, 1999, p. 91).

O conforto nesse período pode ser entendido por duas variantes. A primeira refere-se ao conceito de bem-estar material: ambientes que proporcionavam momentos alegres, descontraídos e propícios ao prazer social e intelectual. A segunda diz respeito ao conceito que está relacionado à fisiologia humana; é uma sensação ligada ao fato de sentir-se bem e confortável fisicamente ao manipular ou relacionar-se com o objeto. Existe também um conceito cultural, que assume distintos significados em épocas diferentes. Como já comentado no capítulo1, com relação às funções semissimbólicas em que os orientais possuem um modo cultural de sentar-se confortavelmente ao chão.

Pode-se dizer então que foi no rococó que houve pela primeira vez um questionamento sobre o conforto. Contudo, os móveis tinham também outros significados, que agregavam simultaneamente funções simbólicas e utilitárias. Peças que possuíam diferentes usos, diferentes formas e diferentes técnicas eram colocadas em cômodos também diferentes, indicando formalidades distintas e comportamentos diversos. Assim, essa "diferenciação", além de ser uma possibilidade utilitária, era uma condição de comportamento individual e social.

Há de se entender que, assim como os vários estilos aplicados, as várias possibilidades formais e as possibilidades técnicas empregadas na produção da mobília pessoal, as transformações individuais, sociais e culturais das pessoas são também de grande relevância.

Como objetos utilitários, com finalidades práticas, técnicas, estéticas e simbólicas, os móveis tornam-se também objetos de desejo, promessa de emoção. A questão mais importante é como eles serão usados e o que as pessoas desejam deles; quais as experiências que eles podem proporcionar enquanto momento vivido, que não se apresenta como apagada lembrança, mas qual sensação interior imediata. Como objetos utilizados e associados à decoração da casa, do lar do indivíduo, os móveis são aquilo que se compõe diante de nós como algo que vem de longe, do indizível, do não dominado, como o símbolo de Goethe.

É a partir dessa fase que se compreende mais nitidamente a passagem do uso do móvel como artefato puramente utilitário para um artefato de símbolo individual, cultural e social.

Schimidt (1974) tenta entender como se dá a relação entre o espaço físico e a forma de morar por meio dos aspectos da habitação. A autora define hábitat como sendo 
o entorno próximo e privado do indivíduo ou da família, lugar de sobreposições entre características denotativas e características estético-afetivas.

Às características denotativas relaciona a questão da função da habitação: abrigar e proteger os indivíduos contra males humanos, naturais e materiais, e igualmente ser o lugar para as atividades cotidianas com utensílios adaptados - a função da sala é para receber e participar da vida social; a da cozinha é para preparar alimentos, e assim por diante. Já quanto às características estético-afetivas, a autora diz que estão presentes no espaço interior e exterior, e as designa como aquelas que são personalizadoras e permitem às pessoas criarem para si um "microuniverso", produzindo características singulares e individuais à habitação.

A partir dessas definições e conceitos, podemos também incluir os móveis nas duas categorias. Primeiro como suportes ou instrumentos que permitem ou promovem a realização das tarefas domésticas e, segundo, como objetos onde são impressas as características histórico-estéticas.

Nas funções práticas ou denotativas da habitação, a importância do móvel é vista como inerente à própria sobrevivência humana, mas é por meio das qualidades estéticoafetivas que se torna possível descrever a sua posição histórica de modo abrangente. Ao apresentarem particularidades de ordem técnica e estética que pedem uma compreensão dos princípios construtivos na fabricação do móvel, é nessas qualidades que também há informações sobre gosto, memórias, ideias predominantes das épocas, processos artísticos, e sobre questões como política, religião e economia, induzindo à outra característica tão importante quanto: a simbólica. Nos elementos personalizadores, que se dão por escolhas particulares como cor, forma, tipologias, arranjos e usos, ligados às experiências individuais, fica impressa a evolução do pensamento e comportamento do homem. Às características estético-afetivas definidas por Schimidt (1974), relacionamos as funções semissimbólicas definidas neste trabalho.

São as características estético-afetivas ou as funções semissimbólicas que podem esclarecer o porquê de tanta variedade de um mesmo móvel, quando sua função prática ou de uso permanece sempre a mesma. Pode-se evidenciar esse pensamento por meio das imagens da figura 26 - banco de madeira, banco indígena, banco em formato de flor e pufe. São produtos tipologicamente de uma mesma categoria, bancos, e que compartilham uma mesma função de uso: repousar (ROCHA, s.d., p. 9) ou descansar (CANTI, 1980, p. 27), embora demonstrem formas muito diferentes. 
O banco de madeira, de formato retilíneo, de constituição e construção simples, de material que se pronuncia por si, é destituído de artifícios e acabamentos que o esconda ou camufle. A sua configuração nos remete à produção artesanal ou semiartesanal. O banco indígena, com configuração que representa um elemento da fauna e uma composição figurativa e detalhista, própria da cultura indígena brasileira, é confeccionado em toro de madeira entalhado em uma só peça e possui pinturas de grafismos que representam ou simulam a textura do animal, e nos leva à produção do artesanato indígena. Já o banco em formato de flor, mais orgânico e sinuoso, possui configuração geométrica e acabamentos mais simples e não tão figurativos quanto o indígena. Este banco sugere um uso coletivo e simultâneo, indicado pelas quatro "pétalas". Quanto ao seu acabamento, propõe uma percepção de caráter artificial que pode ser escolhido de acordo com o gosto do usuário e com seu estilo de vida.

Por fim, o pufe preto, de configuração extremamente geométrica: um cubo. A forma remete ao desenho "primitivo" do móvel, representado pelo cofre (ver ROCHA, s.d.). Com relação ao acabamento, assim como o banco em formato de flor, o pufe remete simbolicamente às referências dos materiais artificiais advindos da industrialização e da produção em série, ou aos cubos pretos da escultura minimalista.
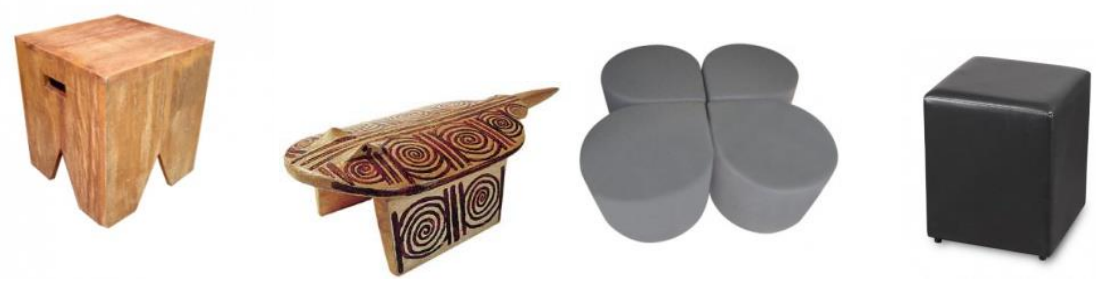

Figura 26 - Bancos variados. Características estético-afetivas ou semissimbólicas

Essas características personalizadoras sempre estiveram presentes na relação do indivíduo e seus objetos. Ora mais proeminentes, ora menos, são elas que instituem o nível de pertencimento, de segurança, levando ao que chamamos de experiência emocional.

Retornando à construção do pensamento de ordem histórica, depois do rococó surgiu a corrente do neoclassicismo. Mais uma vez, o estilo clássico dos gregos ressuscitava. Porém com uma grande diferença: o neoclassicismo era considerado como uma espécie de maneirismo, porque tinha a ideia de aproximação com os clássicos, 
contudo totalmente fora do contexto. Aqui a intenção não era a de fazer "renascer" um pensamento que relacionasse a revalorização do pensamento e da arte da Antiguidade clássica à formação de uma cultura humanista, e sim, relacionava-se à vontade de reformas e de planejamento racional relativos às transformações sociais em curso. É uma "recusa" à arte imediatamente anterior, barroco e rococó - consideradas de atmosfera apoiada na imaginação e virtuosismo individual - e propunha a supremacia da técnica e do projeto como elemento formador da obra ou edifício. Os elementos clássicos acabaram por se tornar adornos para as artes, para as artes decorativas e principalmente para a produção do objeto utilitário.

No neoclassicismo o interesse pelas antiguidades era o de recuperar para a arte e para a produção dos artefatos a pureza da forma e expressão que se julgava faltar no estilo rococó. Já para Forty (2007), o interesse em restaurar uma estabilidade em face da inquietação com o progresso advindo da Revolução Industrial era umas das suas principais razões.

Para as classes ociosas daquele século, boa parte do prazer do estudo da Roma antiga e de colecionar suas relíquias vinha do contato que isso lhes dava com uma civilização que fora aparentemente estável. O desejo de ver princípios de designs clássicos aplicados à vida contemporânea vinha, em parte, de uma vontade de suprimir da consciência a tendência perturbadora de mudança. (FORTY, 2007, p. 27)

Os desenhos antigos disfarçavam as inovações técnicas, pois só a semelhança com verdadeiras antiguidades daria aos artigos alguma possibilidade de sucesso. Na figura 27 podemos notar o uso de linhas retas e uma aplicação mais austera dos elementos decorativos em bronze. "Antiguidade, e não novidade, era a qualidade comercializável” (FORTY, 2007, p. 39). 


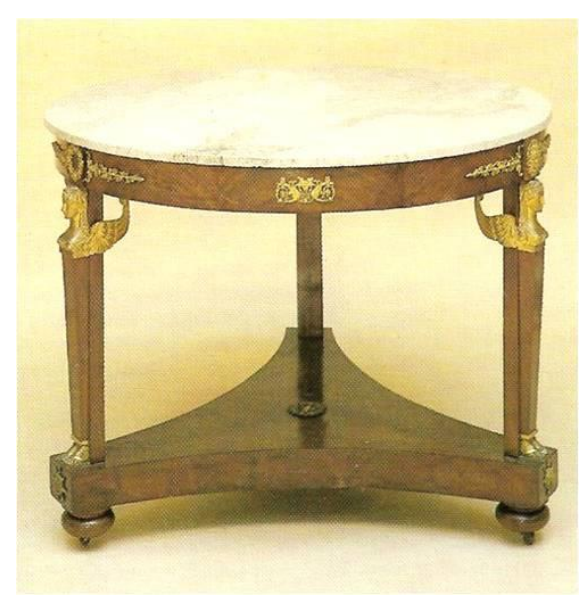

Figura 27 - Mesa estilo Neoclássico

A França e Inglaterra foram palco de situações que contribuíram imensamente para evidenciar a evolução dos interiores domésticos.

A aristocracia francesa formava uma sociedade essencialmente urbana. Perrot (2009) nos conta que a casa como conhecemos hoje, num sistema de tripartição ${ }^{16}$ advém desse período. A burguesia parisiense emergente, ávida por se "igualar" à aristocracia, copiava seus luxuosos estilos de habitação. Para receber a fina sociedade em seu seio familiar em suntuosas festas era necessário um ambiente - sala de estar - amplo e confortável. Para conservar a intimidade e privacidade (cada vez mais significativas) dos membros da família, havia os quartos. Já para os numerosos empregados necessários para os afazeres domésticos, existia uma área de serviço. Assim, dividir a residência em área social, área íntima e área de serviço, foi se consolidando como um modo sofisticado de viver.

Aos ambientes considerados sociais, destinava-se uma dimensão coletiva e pública: tanto para o relacionamento familiar, quanto para recepção de convidados; ou por estarem, em sua maioria, localizados em áreas voltadas para a rua, considerados então, como espaços que estão entre o privado (a casa) e o público (a rua).

Além das dimensões pública e coletiva, essa área deveria produzir um valor de status social; funcionar como um lugar onde a burguesia pudesse ostentar uma imagem como de sua própria família. Por isso, usavam rica decoração e mobílias ornamentadas; tudo compondo para uma cenografia das salas.

\footnotetext{
${ }^{16}$ Este sistema se refere àquele em que a configuração espacial da casa é dividida em três partes: área social, área íntima e área de serviço.
} 
À área íntima, diferentemente da social, destinam-se os quartos, considerados locais da vida privada da família. São nesses cômodos que a identidade do indivíduo ascende, deixando de lado a identidade familiar. O quarto, então, se constitui como um espaço reservado à intimidade, o espaço mais privado da casa.

[...] se entrarmos num quarto burguês dos anos oitenta [1880], apesar de todo aconchego que ele irradia, talvez a impressão mais forte que ele produz se exprima nessa frase: Não temos nada a fazer ali porque não há nesse espaço um único ponto em que seu habitante não tivesse deixado seus vestígios. Esses vestígios são bibelôs sobre prateleiras, as franjas ao pé das poltronas, as cortinas transparentes atrás das janelas. O guarda-fogo diante da lareira. (BENJAMIN,1994a, p. 117118)

A outra situação é apontada por Forty (2007). O conceito de lar sofreu grande influência quando do início da industrialização. Na Idade Média a casa era um local que incorporava o trabalho às atividades habituais de morar, dormir e comer. Quando o trabalho produtivo foi removido para as fábricas, o lar tornou-se um lugar unicamente para dormir, comer, criar filhos e principalmente para desfrutar o lazer.

Para tanto, a fábrica e o escritório viraram sinônimos de local de opressão à classe trabalhadora e o lar transformou-se em um abrigo onde as pessoas buscavam um pouco de respeito por si mesmas. Essa situação levou as pessoas a separarem os dois espaços, não só fisicamente, mas também emocionalmente. Assim, o lar passou a ser considerado um repositório das virtudes perdidas ou negadas no mundo exterior, e essa representação tinha o objetivo de "[...] transformar o lar em um lugar de ficção, um lugar onde florescia a ilusão" (FORTY, 2007, p. 140). Às mulheres cabia a tarefa de preservar o aspecto sacrossanto da casa. Os vitorianos adotaram várias estratégias de comportamento para satisfazer essas ilusões; uma delas foi o desenvolvimento de padrões especiais de gosto e design para o lar. Na escolha da mobília ou na harmonia das cores, o ambiente tinha de eliminar todas as associações com o trabalho.

Nesse sentido, o lar transformou-se em um lugar que estimulasse a dissociação total entre o mundo interior e o mundo exterior.

$\mathrm{O}$ ambiente em que se vive se contrapõe pela primeira vez, para o homem privado, ao lugar do trabalho. O primeiro se constitui no interior, o escritório é o seu complemento. O homem privado, realista no escritório, exige do interior que o mantenha em suas ilusões. Esta necessidade é tanto mais estimulante quando nem pensa em estender suas reflexões mercantis às sociais. Reprime ambas ao configurar seu 
entorno privado. E assim resultam as fantasmagorias do interior. Para o homem privado o interior representa o universo. Reúne nele o longínquo e o passado. Sua sala é a platéia no teatro do mundo (BENJAMIN,1973, p. 167-168).
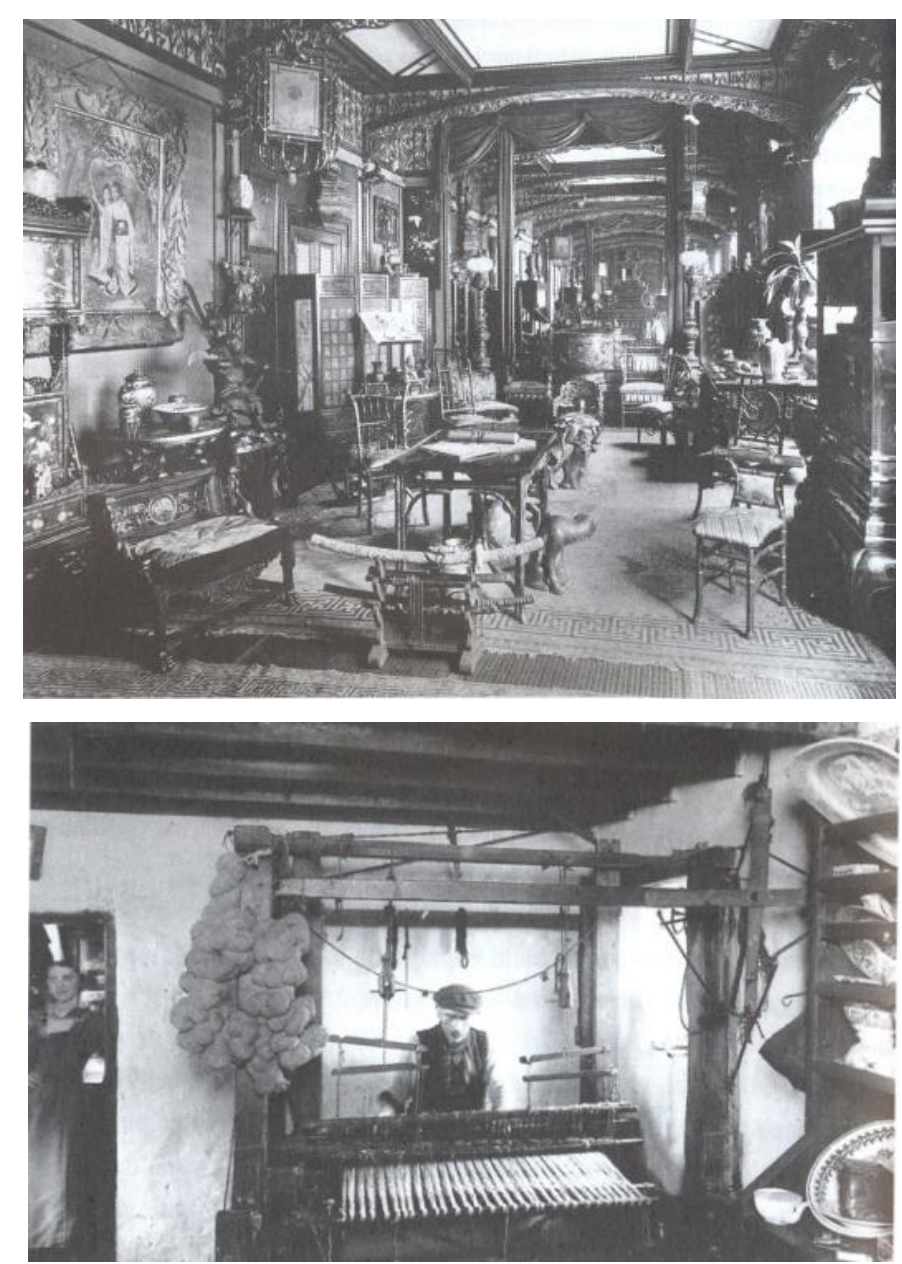

Figura 28 - Ambiente burguês do século XIX, que deveria ser uma antítese do ambiente de trabalho e que estimulasse prazer e bons sentimentos; e ambiente em que a produção de tecidos era feita em meio à vida doméstica

Como podemos perceber, o conceito de lar como conhecemos hoje, não se dá apenas a partir da incorporação da domesticidade e do binômio público x privado, mas também como resultado da revolução industrial. A partir do momento em que as pessoas deixaram de realizar suas obrigações profissionais dentro de suas residências e passaram a trabalhar em fábricas, escritórios e lojas, a casa adquire um novo e diferenciado patamar na vida das pessoas, e isso foi refletido diretamente em sua decoração, por conseguinte, na conformação dos móveis.

As imagens da figura 28 demonstram a configuração de dois lares, bem como de suas mobílias, a partir da inclusão e da dissociação da atividade profissional de dentro 
das casas. A exigência básica dos novos lares era que se deveria eliminar toda e qualquer associação com o trabalho. Segundo Garret (apud FORTY, 2007, p. 141) a sala de visita moderna começou a exibir com certa frequência um estilo "espalhafatoso e teatral" na decoração e mobiliário. Essa representação do lar deu-lhe um status de ficção e ilusão que deveria, inclusive, eliminar os "maus sentimentos". Para tanto, os móveis residenciais começaram a ficar coloridos, macios e aveludados.

[...] a partir do louvável desejo de excluir todos os pensamentos e objetos do dia de trabalho, a sala de visita moderna exibe com demasia frequiência um estilo espalhafatoso e teatral de decoração e mobiliário [...] (GARRET, 1879, p. 56 apud FORTY, 2007, p. 141)

Os burgueses ingleses passavam a maior parte do tempo em casa, visitando-se mutuamente, jogando e bordando. Essas atividades transcorriam em torno da casa, e assim a moradia adquiriu uma importância social jamais vista, antes ou depois. A residência era um lugar social, mas com privacidade.

Durante todo o século XIX a "beleza" foi o principal requisito a ser adotado como meio para que o lar atingisse o seu lugar de santidade. No conceito de beleza, além de conforto e satisfação dos sentidos estéticos, havia a significativa representação das virtudes morais da verdade e da honestidade. Às mulheres, mais uma vez, cabia a responsabilidade pela busca da beleza, por seus efeitos morais sobre os outros membros da casa.

Buscou-se então a "mobília de arte", conceito que surgiu devido ao fato de que não se achavam no comércio móveis que satisfizessem os padrões estéticos e morais de beleza, como, por exemplo, honestidade moral e honestidade das formas e dos materiais. O objetivo do mobiliário com arte era o de reduzir a quantidade de móveis e criar mais espaço nas salas e quartos.

Os móveis pesadamente estofados foram deixados de lado, em favor de cadeiras de estrutura de madeira e canapés com almofadas soltas. Móveis escuros, dourados e cores como escarlate foram banidos em favor de tons pastéis e trabalhos de marcenaria pintados de branco. Tapetes sobre assoalhos de madeira ou tacos eram preferíveis a carpetes. Em todas as dependências, buscava-se um ar de informalidade e não se estimulavam as simetrias no mobiliário. Por fim, o mais importante de tudo: imitações e tapeações estavam proibidas. Mobília que disfarçasse o modo como fora feita, ou seus materiais, era considerada desonesta e, portanto, deveria ser evitada. (FORTY, 2007, p. 154) 
THE SUSSEX RUSH-SEATED CHAIRS

MORRIS AND COMPANY

++4 OXFORD STREET, LONDON, W.
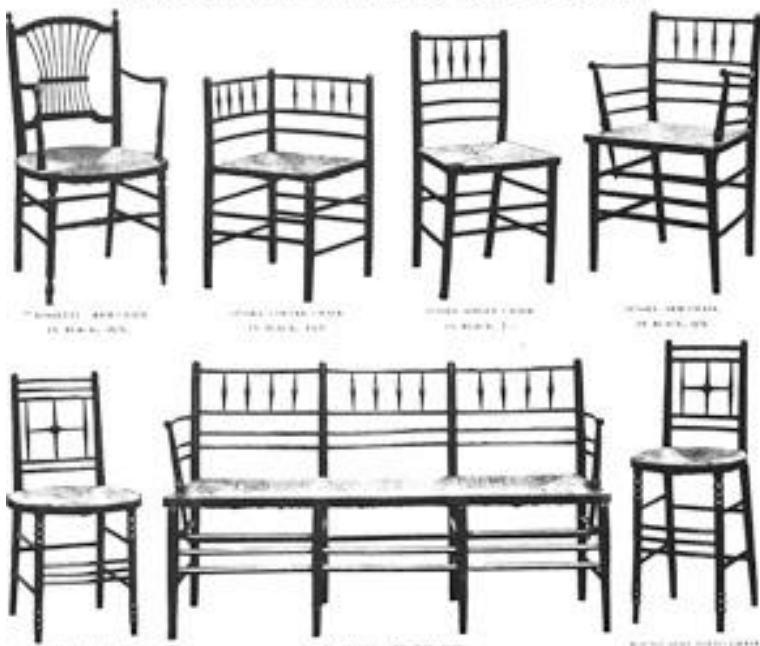

Figura 29 - Catálogo dos móveis Morris \& Company Móveis fabricados por Willian Morris

A figura 29 retrata as famosas cadeiras fabricadas por Willian Morris no século XIX. Essas peças eram projetadas e produzidas segundo os novos preceitos de "honestidade", em que fora banido todo e qualquer elemento decorativo que pudesse demonstrar imitação ou camuflagem. Os ornamentos eram restritos à aplicação de delicada marchetaria. Vale ressaltar que nesse período o processo de industrialização no setor moveleiro já estava totalmente disseminado, e novas técnicas estavam sendo criadas, como por exemplo, a que curvava peças em madeira sob pressão térmica.

Outro aspecto extremamente importante que se deve destacar é a questão da limpeza e higienização. Ainda que a limpeza tenha um viés significativamente relevante - sua relação científica com a saúde ${ }^{17}$-, esse não foi o único significado. Forty (2007, p. 217) explica que enquanto categorias neste contexto, limpeza e sujeira são subjetivas: o conceito que estava por trás era o de "impor ordem ao mundo". Esse autor faz uma relação com o temor burguês de perder o poder e a autoridade social e política, não lhe parecendo implausível que um "regime de limpeza e ordem" fosse adotado pela classe

17 Junto à teoria miasmática, que considerava a ventilação dos ambientes uma profilaxia eficiente, em 1860 Louis Pasteur e Joseph Lister haviam estabelecido a base para uma teoria microbiana. A atenção foi então dada a tudo que pudesse carregar germes, e isso, além de moscas, ratos e baratas, incluía objetos, vestuário e os equipamentos domésticos. 
média como reação à convulsão social e para lhe inspirar alguma segurança psicológica contra ela.

A partir da última década do século XIX, tanto na Europa quanto na América surgiram estratégias de saúde pública que partiram de profissionais liberais e reformistas sociais. A atenção foi dispensada a vários setores da vida cotidiana: do vestuário à poeira doméstica; da alimentação das crianças ao alcoolismo. Lar, lojas, escolas, edifícios públicos, vagões de trem, tudo recebeu uma atenção cuidadosa. ${ }^{18}$

Para Forty (2007, p. 299-230), a questão da limpeza e higiene foi colocada como uma questão de apelo emocional: "O menor desvio da limpeza perfeita era causa de ansiedade social, pois a passagem invisível dos germes podia pôr em risco a saúde da família, dos companheiros e até de toda a nação".

Essa postura obviamente foi instaurada no design dos objetos. Na mobília, isso influenciou sobremaneira na forma e na substituição dos materiais retentores de pó, como tecidos rugosos, veludos, formas entalhadas e com muitos detalhes, por materiais de superfície lisa, linóleo, encerado ou couro. A tecnologia do ferro fundido ou em barras também foi um passo à frente.

No final do século XIX grande parte da mobília já incorporava traços "higiênicos" de limpeza formal: mínimo de relevo ornamental e formas mais geométricas e menos "rebuscadas". A relação entre indivíduo e objeto era baseada na ação simbólica voltada para duas vertentes: uma levava à questão de ordem e organização; a outra incluía os avanços do desenvolvimento industrial e, consequentemente, suas tecnologias e processos.

Há de se considerar também a não menos relevante questão do surgimento do movimento Art Nouveau. Vários autores, como Pevsner (1994), Argan (1992a) e Bomfim (1998), o colocam como símbolo de identificação enquanto classe social (aristocracia e burguesia) e reação ao estilo racional da indústria. O Art Nouveau surgiu como um ornamento expressivo da era industrial. Paradoxalmente ao contexto da influência da higienização, as formas assimétricas, de motivos ornamentais, formas orgânicas inspiradas na natureza do estilo, denotavam uma estetização da vida, superando a linguagem fria e racional não só da industrialização como também do conceito ideológico de vida racional, já disseminado na sociedade, como ilustra a figura

\footnotetext{
${ }^{18}$ Surgiram então escolas que ensinavam as meninas sobre o serviço doméstico, bem como as preparavam para o casamento. Na grade de disciplinas estavam técnicas de limpeza (como tirar pó e limpar o chão), explicações sobre técnicas nutricionais para uma boa alimentação e acerca das causas das doenças.
} 
30. Foi uma tentativa de inserir uma segunda natureza à rudeza industrial: "O estilo floral do Art Nouveau gostaria de revesti-la [a cidade e os objetos] com sua ornamentação alastrante como uma trepadeira, convertê-la numa segunda natureza" (ARGAN, 1992, p. 189).

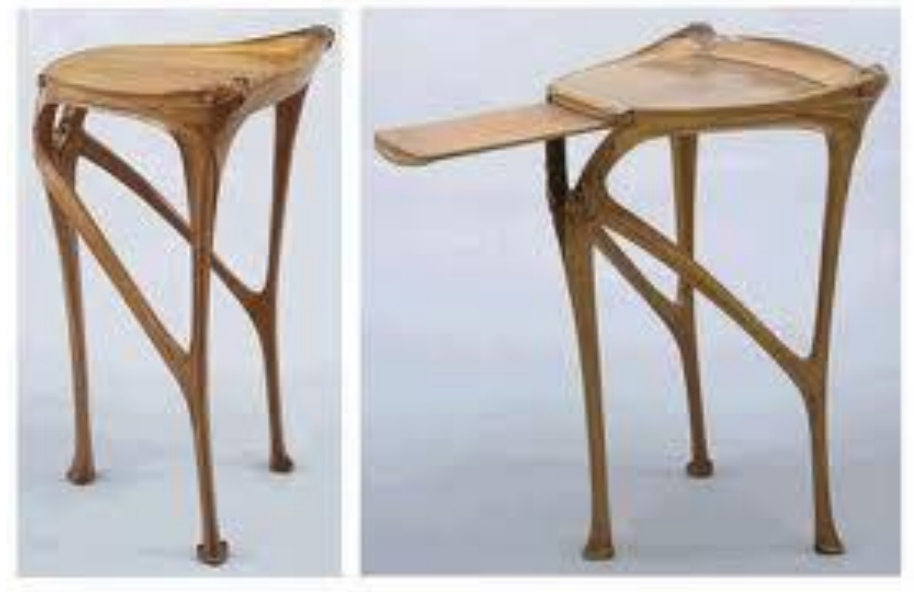

Figura 30 - Mesa estilo Art Nouveau

Segundo Bomfim (1998), apesar de suas características peculiares, tanto o movimento Arts and Crafts quanto o Art Nouveau possuem semelhanças. A primeira é que os dois propuseram produtos baseados na produção artesanal e industrial como meio de melhorar a qualidade estética dos produtos. A segunda é que ambos encontraram seus fundamentos na tradição: o Arts and Crafts lutou contra o historicismo e pregou o retorno à ordem da Idade Média; o Art Nouveau, engajado com a burguesia, buscou no humanismo da Renascença sua fundamentação. Foram movimentos que se inspiraram no passado e não poderiam apresentar uma solução ao problema colocado pela estética industrial que, por sua vez, buscava soluções formais junto ao novo contexto da produção industrial.

$\mathrm{O}$ século XX trouxe várias situações que definiram o modo de viver da sociedade. Uma delas foi que o conforto, considerado uma condição que antes era privilégio de apenas uma pequena parte da população, se difunde com a industrialização e a democratização da produção em massa. Grande parcela da população passou a ter em suas casas equipamentos e aparelhos que facilitavam o serviço doméstico e que melhoravam as condições de aquecimento e iluminação.

Nessa etapa da história a posição que a mulher assume perante a sociedade, à família e a casa tem relação direta com o indivíduo e sua residência, com os móveis e 
objetos e a configuração do espaço interno. No período das guerras na Europa, as donas de casa foram impelidas a trabalhar nas lojas e escritórios do mundo industrial, substituindo os homens que haviam ido para a guerra. As carentes foram movidas pela necessidade financeira, as de classe média e as de famílias mais abastadas exigiam seu direito de trabalhar fora como o homem. Os diversos aparelhos para o lazer ou para facilitar o serviço doméstico, como eletrodomésticos, televisão e rádio, tornaram-se imprescindíveis. Com a incorporação desses aparelhos nas despesas familiares, o salário da mulher tornou-se indispensável. ${ }^{19}$

Rybczynski (1999) salienta que as condições de conforto de quem realizava as tarefas domésticas foram amenizadas a partir da inserção dos aparelhos eletrodomésticos, pois proporcionavam a realização das atividades com menor esforço. No início do século XX a mulher norte-americana fazia a maior parte do serviço doméstico, pois além de haver tecnologia acessível elas tinham renda para adquiri-los.

Boyle (1993) observa que na Inglaterra os empregados domésticos migraram para outro tipo de trabalho, devido ao aumento da oferta de empregos nos escritórios e nas indústrias. As casas tornaram-se menores, mais práticas e com menos móveis. As tarefas diárias eram mantidas pelas próprias donas da casa, auxiliadas por eletrodomésticos que permitiam economia de mão de obra e redução do serviço. “[...] cunhou-se uma nova expressão para descrevê-los: 'labor saving appliances' (aparelhos de redução de trabalho)", (RYBCZYNSKI, 1999, p. 89).

Por volta de 1910, nos Estados Unidos, o serviço doméstico foi posto no centro da vida da mulher de classe média ${ }^{20}$. A cozinha foi o lugar da casa que mais passou por alterações significativas nesse período:

[...] do forno de ferro fundido e dos fogões a gás e elétrico, maior diversidade de panelas e recipientes, provocaram um aumento e a separação da cozinha. Que gradualmente passou a rivalizar com a sala de estar enquanto ponto focal da vida

19 Rybczynski (1999) assegura que era necessário algum tipo de energia para fazer funcionar as tecnologias que iam acontecendo na atividade industrial para dentro da residência. $\mathrm{O}$ gás foi a primeira fonte de energia artificial inserida na casa, seguido pela eletricidade e pelo gerador elétrico, depois pelo aquecedor com resistência e pela lâmpada incandescente. Com a eletricidade dentro das casas, apesar de seu largo uso ocorrer primeiramente na iluminação, ela poderia ser utilizada como fonte de energia para outras funções.

20 As americanas Christine Frederick e Lillian Gilbreth, que ficaram conhecidas como engenheiras domésticas, difundiram a idéia da casa eficiente. Foram criados cursos de economia doméstica e o trabalho doméstico foi redefinido como uma ciência exata. As técnicas do estudo do tempo, desenvolvidas para o trabalho na indústria, foram aplicadas pelas engenheiras a fim de racionalizar o trabalho da casa. 
familiar: agora ela já não ficava no porão como antigamente, mas no andar térreo, perto da sala de jantar. Seu projeto passou a ser cuidadosamente ponderado e suas paredes foram revestidas com papel lavável; as mesas tiveram a altura cuidadosamente planejada para oferecer as condições de trabalho mais propícias. (BOYLE, 1993, p. 159)

A partir dessas condições é que surgiram os primeiros conceitos de cozinha planejada como ilustrado na figura 31. Armários multifuncionais: fáceis de montar, de manipular, de limpar; enfim, fáceis de usar. Muitos materiais, naturais ou artificiais, como laminados plásticos ou de madeira natural, foram desenvolvidos pela indústria como opção de acabamento para a superfície de trabalho, já que proporcionavam maior higiene, durabilidade e facilidade de limpeza.

De arquitetos modernos e exposições de artes decorativas à indústria que produzia produtos inovadores para a casa, todos os esforços estavam voltados a tornar o domicílio um local mais "funcional" e independente das questões de ordem decorativa atreladas aos estilos históricos. É nessa época também que se instaura o american way of life, que tinha o objetivo de divulgar o estilo de vida americano, e junto com ele seus produtos industrializados. A mais nova (e talvez a mais importante) atração do lazer doméstico, a televisão, instalou-se definitivamente em posição de destaque nas salas de estar. Surgiram então móveis que não apenas servissem de apoio, mas convertessem a televisão num objeto de destaque.

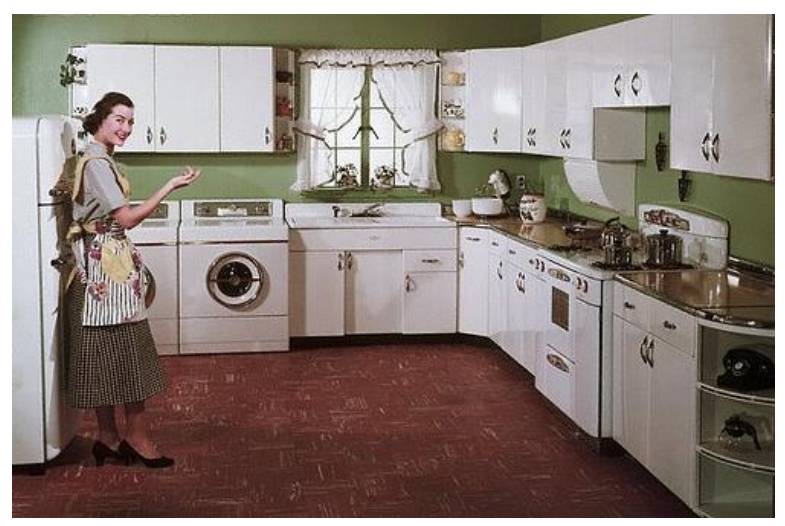

Figura 31 - Cozinha no estilo american way of life

A constituição do ambiente doméstico e do conforto foi gradual, e as mudanças mais significativas em relação à residência ficaram restritas ao espaço interno. Contudo, no início do século XX, paralelamente aos avanços tecnológicos ligados ao 
desenvolvimento do conforto humano na residência, uma revolução estética que envolvia a relação direta do ambiente interno e externo estava a caminho.

A sociedade europeia buscava um estilo original e novo, de acordo com os novos tempos e ante o progresso técnico. A influência do historicismo, do ecletismo e do excesso de ornamentações começou a encontrar intensa aversão. ${ }^{21}$

Com a expansão do comércio internacional a Europa passou por um período de prosperidade econômica até a $1^{\text {a }}$ Guerra Mundial, período conhecido como Belle Époque. Entre outros fatores, este abriu campo para experiências artísticas de vanguarda que procuravam um estilo "inédito" e sem influências dos anteriores. Haveria de se criar uma nova possibilidade de linguagem para a criação e desenvolvimento de projetos: não era mais possível projetar baseado em estilos passados. Movimentos estéticos e artísticos como o Art Nouveau, De Stijl, o Futurismo e o Cubismo foram base para o movimento moderno.

Aquilo que pudesse representar o passado foi retirado, inclusive o conforto burguês foi deixado de lado. Rybczynski (1999) aduz que o modernismo é um modo brando de esnobar aquilo que pudesse parecer familiar.

\begin{abstract}
A decoração de interiores segue a arquitetura. Os arquitetos haviam aprendido a lição e não iam perder o controle sobre o interior dos seus prédios, como haviam feito no século XIX. A arrumação do interior não podia cair nas mãos dos decoradores de interiores. Um prédio moderno era uma experiência total; não só a disposição interna, mas também os materiais de acabamento, a decoração, os acessórios e a localização das cadeiras eram planejados. $\mathrm{O}$ que resultou em cômodos de uma consistência visual que não era vista desde o rococó [...] Os interiores mais admirados eram aqueles onde tudo havia sido projetado por um só arquiteto - inclusive a iluminação, as maçanetas e os cinzeiros. E é claro, os móveis, especialmente os móveis. (RYBCZYNSKI, 1999, p. 103)
\end{abstract}

O foco à originalidade e a insistência pelo novo fazem que o projetar esteja totalmente voltado às formas de produção industrializada e na utilização de novos materiais. Assim, o movimento moderno provoca uma ruptura total com o passado e com aquilo que fundou, aprimorou e desenvolveu o móvel e a configuração do espaço interior até então. A arquitetura moderna para residência não foi aceita imediatamente, igualmente os seus móveis.

\footnotetext{
${ }^{21}$ Consultar Bayeux (1997), Argan (1992a) e Pevsner (1994).
} 
Os arquitetos modernos eram também adeptos do ideário socializante de William Morris, mas não acreditavam no poder da construção de uma estética como totalidade da atividade humana, cognitiva e afetiva sem apelar para a indústria. O ideal de seus pensamentos era a tônica na arquitetura da cidade, "mas da cidade do trabalho, não a cidade-refúgio do privilégio" (Katinsky, 1999, p. 36).

Sem dúvida, a arquitetura e o design modernos demonstraram a sua intenção de transformar a sociedade a partir da habitação e de seus objetos. Contudo, na maioria de seus exemplos, embora de raiz inovadora como nunca visto antes, não conseguiram atingir os seus objetivos inteiramente, pois o indivíduo a que se propunham ainda se encontrava despreparado para recebê-los. Introduziram o racionalismo, as novas formas de distribuição funcional e os princípios higienistas, bem como estabeleceram a repetição e a simetria. É sensato afirmar que a arquitetura e o design modernistas discutiram profundamente os modos de habitar e usar os objetos a partir de propostas experimentais estandardizadas.

A criação do "modelo standard" deu origem a objetos extremamente estáticos que possuíam uma mesma sintaxe, em que a individualidade e a diversidade do indivíduo se viram interrompidas pelo padrão. Como resultado, a consequente perda de identidade da casa e do sujeito.

Se por um lado, os objetos pautados por princípios modulares produzidos industrialmente em série tinham a competência de resolver os problemas com relação à rapidez e à economia produtiva, por outro conferiram um modo de vida também estandardizado ao indivíduo e à sociedade.

Tanto para o entendimento do processo produtivo e seus sistemas, para o desenvolvimento de processos e métodos de projeto, quanto para a formatação do design enquanto profissão trata-se de um passado próximo importante. Apesar de ter chegado a um estado de ruptura com o tradicional, foi um período intensamente prolífero que proporcionou ao design um desenvolvimento e autonomia sem precedentes. O grande questionamento que se faz é que essa proposição virou dogma, não permitindo espaço para reflexão.

Atualmente fala-se sobre as transformações e mudanças que estão ocorrendo nos conceitos de casa e de lar. Contudo, em sua essência, estes conceitos são ainda pouco dados a mudanças. Como pudemos ver ao longo do texto, a casa sempre foi o lugar do indivíduo, onde este encontra abrigo, bem-estar e conforto. Os conceitos de 
estabilidade, permanência e continuidade ainda estão presentes e é na casa e por meio de seus objetos que o indivíduo constrói o seu mundo de referências, a sua vida.

É certo também que as necessidades básicas inerentes ao ser humano se encontram decisivamente à mercê de condicionantes culturais e locais que tornam indispensável e essencial uma redefinição da função, da forma e da estética que envolve a casa e seus objetos, assim como, de sua dimensão simbólica.

A complexidade, a mutabilidade e a indeterminação da vida do sujeito contemporâneo constituem fatores decisivos para um novo pensar do interior doméstico, estabelecendo um cenário que melhor se adapte ao seu estilo de vida. A permanência, a previsibilidade e a rigidez, que caracterizaram o projeto moderno estão sendo substituídas por mecanismos abertos, em que a ideia de sistema ${ }^{22}$ é uma das grandes correntes.

A habitação, assim como os objetos que compõem seu cenário, atravessa um momento determinante no que diz respeito à relação entre a casa e o seu habitante. Ela já não é mais um local idílico, manifestado como abrigo, conforto e bem-estar, e que foi sinônimo de lazer e privacidade, como na casa burguesa do século XIX até bem pouco tempo. Atualmente, ela está aberta ao mundo, um local onde o trabalho, a informação, a (inter) comunicação e a ciência penetram em sua esfera. As tecnologias adentram a habitação, desmaterializando as suas paredes, a sua estabilidade e os seus limites. Para além do seu caráter mítico de proteção como citado inicialmente em Homero, a casa hoje é um espaço simbólico em ativa inconstância.

A evolução e inserção da tecnologia na vida cotidiana e as transformações da sociedade complexa a que assistimos hoje são consideradas as grandes responsáveis pelas alterações do espaço habitacional contemporâneo. Conceitos como família, imobilidade, privacidade e intimidade estão sendo colocados à prova.

A casa encontra-se imersa num mundo tecnológico que desmaterializou os seus limites e consequentemente interferiu nos conceitos pré-estabelecidos. O computador, o aparelho celular, o ipod, o ipad, os sistemas home theater e tantos outros aparelhos eletrônicos que trazem tanto o trabalho, como o mundo exterior para dentro da casa, emergem e reinterpretam as características do espaço habitacional, dos equipamentos e utensílios domésticos, assim como do mobiliário. Esta condição acena a uma potencial construção de novos paradigmas. Além disso, a estrutura social contemporânea está

\footnotetext{
${ }^{22}$ Um todo organizado e complexo; mecanismo aberto que ajusta múltiplas combinações e manifestações formais como um rizoma.
} 
totalmente modificada, e é cada vez mais difícil definir uma casa-ideal ou objeto-ideal, dada a existência de uma grande diversidade de grupos e de indivíduos.

Nóbrega (2011) nos fala dos há_bit(at) e dos há_bit(antes), edificações cíbridas ${ }^{23}$ e seus habitantes respectivamente. Coloca-nos discussões acerca dos novos códigos estético-simbólicos da residência e de seus moradores. O autor discute privacidade, fechamento, imobilidade, tão presentes nos conceitos fundadores de lar, contrapondo-os aos conceitos de virtual, rizoma e mobilidade junto à atualidade da cibercultura. Troca o conceito de família nuclear pelo de matilha, um todo coletivo e móvel.

Moura e Ricceti (2010), acerca do lar do futuro, propõem três agentes transformadores que podem provocar modificações na conformação da casa. O primeiro são as inovações tecnológicas presentes no dia-a-dia das pessoas, em que a miniaturização, os aparelhos em rede e sem fio caracterizam os objetos; o segundo diz respeito ao desenvolvimento sustentável que deve mudar hábitos e valores e substituir a quantidade pela qualidade; e por último os novos modos de comportamento do indivíduo e das estruturas familiares, que estão modificando as composições e os arranjos físicos do lar, como ilustram as figuras 32 e 33.

Faz-se então a necessidade de encarar a casa, o modo de morar e as relações entre sujeito e objeto de outra forma.

Atualmente, Bauman (2007) usa os termos "líquida", "fluida" ou "inconstante" para descrever a sociedade atual. As conexões clássicas entre o indivíduo e o coletivo dissiparam-se; já não é mais necessário permanecer num lugar fixo, pelo menos de forma imóvel. A natureza do indivíduo atual é "líquida", "híbrida", e, segundo o autor, já não pertence a um lugar, mas a um tempo "líquido". E nessa fluidez, liquidez, e inconstância as suas energias são empregadas em recuperar e conservar a sua individualidade.

A habitação do indivíduo contemporâneo há de ser, portanto, adaptável, e que possibilite troca e usos múltiplos, ou flexíveis. Este espaço pode transformar-se igualmente com os seus habitantes e ter vida própria, converter-se no reflexo constante de identidades, ser a materialização de um espaço vital, extensão da existência. Nele, quem estabelece e quem comanda é o indivíduo e suas necessidades.

\footnotetext{
${ }^{23}$ Edificações cíbridas, segundo o autor, "são aquelas que possuem modos poéticos de hibridização da casa, ente material, com o ciberespaço, ente virtual, visando com essa simbiose construir um espaço cíbrido para morar na arte".
} 
Os móveis - aquele cofre, móvel primeiro, com suas relíquias -, que neles ora sobressaíam funções técnicas ou de uso, ora funções semissimbólicas, guardam segredos e propõem relações, criam e recriam realidades. Pertencem à esfera entre o público e o íntimo. São aqueles pelos quais os sujeitos falam de si próprios, de suas memórias, de seus desejos, sonhos, medos, e valores.

Como participante ativo da condição de morar, o móvel se circunscreveu na formação do lar, da casa, e do cotidiano, e como objeto com fortes características semissimbólicas, podemos afirmar que cada móvel "vale pelo significado que lhe atribui quem dele tem necessidade e por ele desejo, e a relação já não é normativa, como se o objeto levasse em si instruções para o seu uso, mas também empatia e simpatia" (ARGAN, 1992, p. 257).

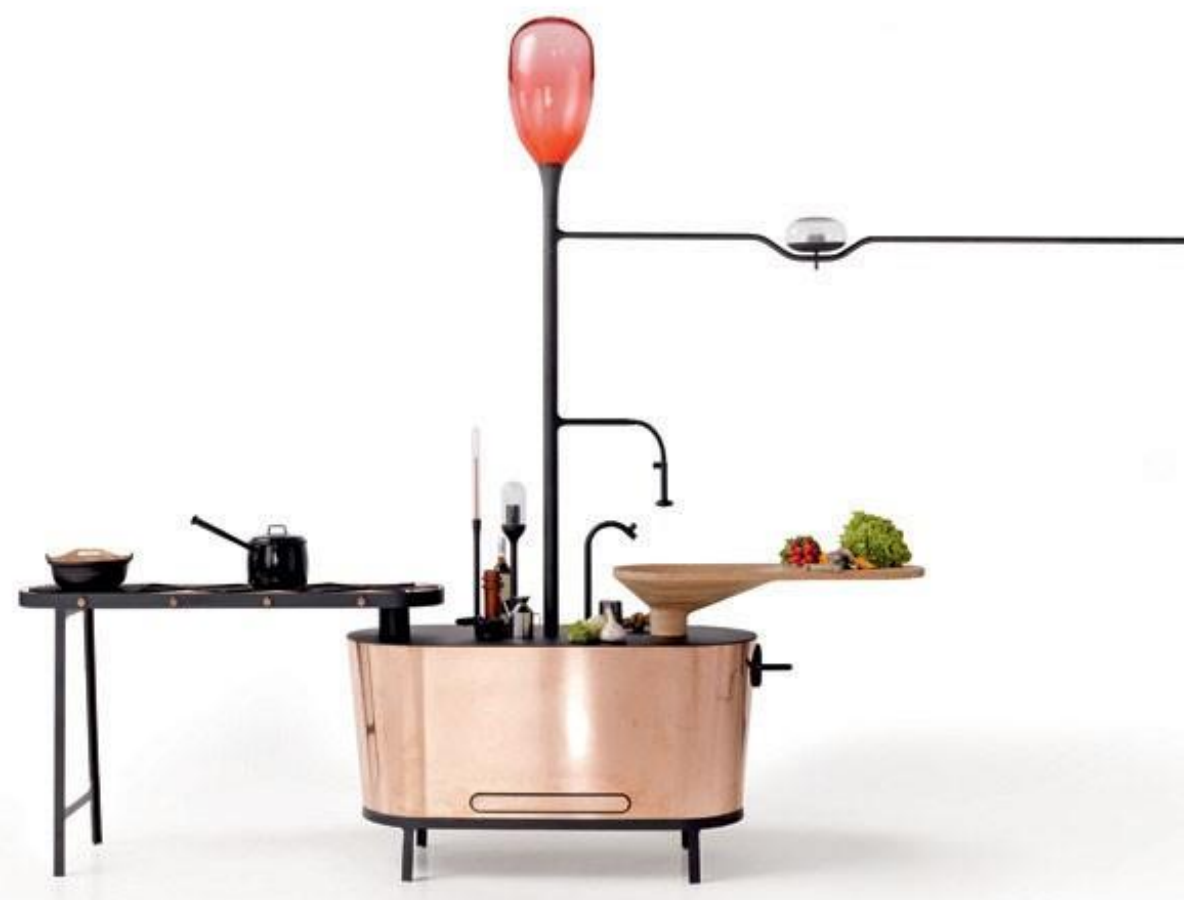

Figura 32 - Cozinha Microbial Home (2011), da Philips, que transforma resíduos domésticos em gás metano, usado como energia 

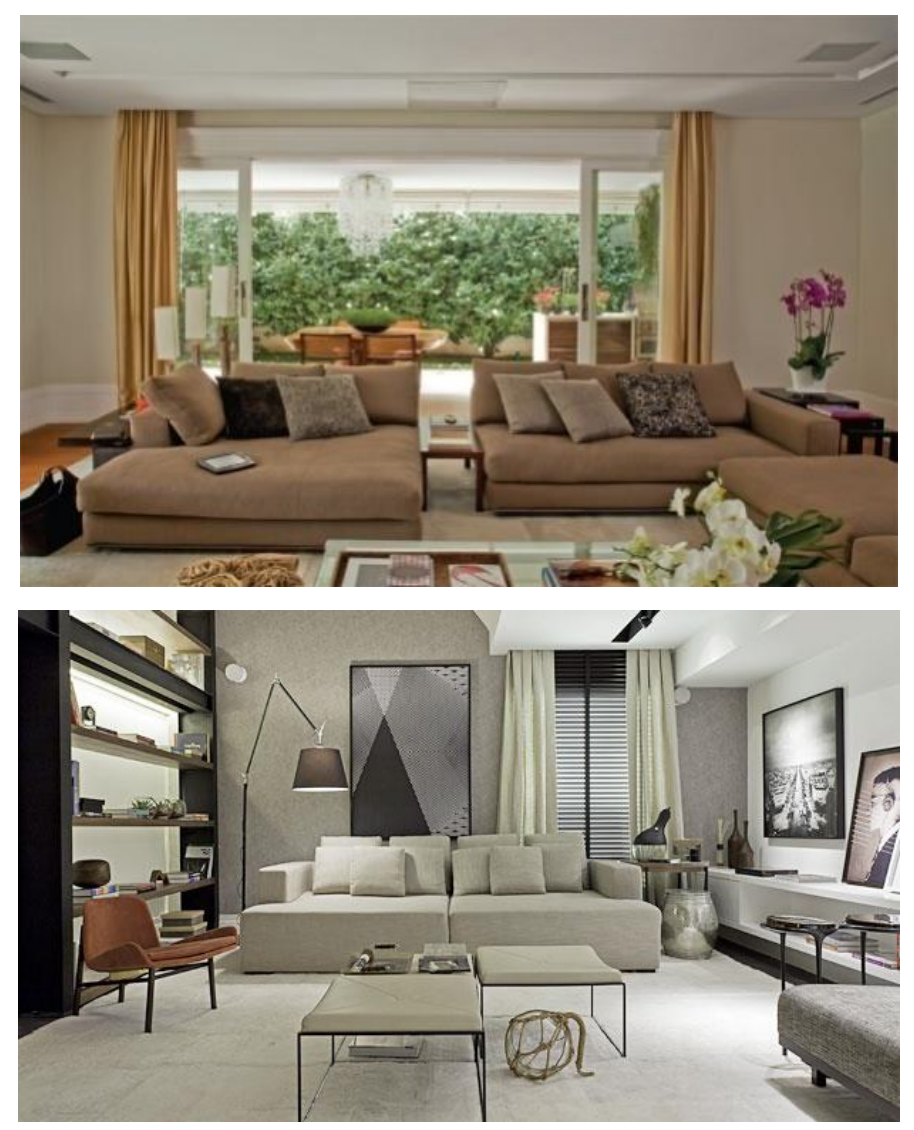

Figura 33 - Sofás (chaise longue) para home theater que possuem como característica uma extensão para apoio das pernas e modo mais confortável e despojado para sentar: adaptação do ambiente tecnológico ao cotidiano e às dinâmicas de uso 


\section{FORMAÇÃO DO MÓVEL BRASILEIRO}

Neste capítulo faremos um breve levantamento e análise acerca da formação do mobiliário brasileiro. Se no texto anterior, o objetivo foi entender as relações entre a mobília, a casa e os conceitos de intimidade e privacidade, aqui temos a intenção de fazer outra investigação.

Foi realizada uma pesquisa qualitativa e pontual que identificasse na história da produção moveleira questões e características que nos levasse a explicitar as razões pelas quais o objeto "móvel" brasileiro deve ser considerado exemplo de design emocional.

Objetos que geram diferentes significados; que são ricos em significação; que contradizem as exigências da avaliação funcional radical e geram nostalgia, evasão, testemunho, lembrança; objetos que evocam memórias e contam histórias numa linguagem formal. Preguiceiro, namoradeira, cristaleira, criado-mudo: denominações de mobília em que a utilidade se confunde com seu próprio valor simbólico e que ao longo do tempo e das experimentações vão adquirindo ressimbilizações que são traduzidas nos usos, nas formas e nos materiais.

Segundo Maria Cecília Loschiavo dos Santos (1995, p. 15), os principais fatores que antecederam, influenciaram e impulsionaram o desenvolvimento da produção do móvel no Brasil foram: a) o uso da madeira e suas técnicas de fabricação nos móveis, como herança cultural, derivada dos portugueses; b) a suspensão das importações, no período das duas Guerras Mundiais; c) a modernização cultural e econômica que se refletiu, expressivamente, na arquitetura; d) e as relações do design brasileiro com o Concretismo.

$\mathrm{Na}$ história do mobiliário brasileiro é necessário considerar as várias influências que se fizeram presentes. As raízes referentes ao processo de miscigenação cultural próprias da cultura brasileira deixaram suas marcas e peculiaridades em suas tipologias de equipamentos domésticos e hábitos de uso.

Segundo Gilberto Freyre (2013), em casa Grande e Senzala, há três pilares de formação do povo brasileiro: o índio, aquele de espécie nativa; o negro, aquele povo que foi trazido como mão-de-obra escrava; e o branco, aquele que agiu como colonizador. Ao enveredarmos essas colocações em busca da origem do móvel brasileiro, podemos dizer que os povos indígenas trazem consigo as distinções das condições climáticas e geográficas de seu hábitat nativo. Os negros, além das manifestações materiais, 
conservaram sua cultura nos hábitos religiosos e culinários. Já os brancos, em um primeiro momento representados pelos portugueses, durante o período colonial, e depois pelos imigrantes, trouxeram exemplares de mobiliário cujos estilos eram baseados na evolução das artes da metrópole e nas correntes estilísticas europeias do período.

No processo de colonização, a cultura material dos brancos se estabeleceu sobre a cultura indígena local e dos escravos. Contudo, vale observar acerca das influências e do processo de hibridismo que se verificaram entre esses três eixos culturais, sobretudo no desenvolvimento do mobiliário brasileiro.

Moraes (2006, p. 262) nos fala sobre o design brasileiro contemporâneo como um exemplo de produção híbrida, em que aporta forte presença dos "signos híbridos e de uma energia singularmente brasileira”. Podemos dizer que essa característica é positiva diante da complexidade da contemporaneidade, e é dada justamente pelo processo da formação da cultura brasileira que passou por ações de mesclas culturais e de sua capacidade de aceitação e adaptação.

Assim, apesar da destacada influência da cultura material dos colonizadores ou do processo de modernização com a abertura das importações pelos quais o país passou, o mobiliário brasileiro contém traços e características que podem ser assinalados como "híbridos" de uma cultura, ela própria, híbrida. Por hibridização ou hibridação, nos referimos a um processo fértil em que há uma "ressimbolização" que preserva a memória dos objetos, e em que a elasticidade entre elementos díspares acende a novos objetos que correspondem a tentativas de tradução ou de inclusão da cultura de origem em outra cultura.

Canclini (1990) e Hall (2001) dizem que hibridação são processos socioculturais em que diferentes estruturas se deparam e se articulam, gerando outras estruturas, às vezes incomuns, com particularidades que podem ser absorvidas por ambas as partes. Contudo, são processos que não garantem equilíbrio, chegando a ser conflituosos e, por isso, podem gerar novas práticas e processos.

Bakhtin (1990), ao tratar do conceito de dialogismo, faz referência a um processo pelo qual duas vozes andam juntas e se afrontam no território do discurso. Para o autor, dois pontos de vista não se unem, contudo se cruzam dialogicamente. Ou seja, as vozes de diferente natureza não se misturam no sentido de fusão ou de homogeneização, mas no sentido de justaposição. 
Assim, quando expomos que o mobiliário brasileiro tem características híbridas, estamos dizendo que as várias influências pelas quais o país passou foram favorecidas pelas diversas mesclas interculturais e formam "vozes" justapostas.

\subsection{Equipamentos domésticos do povo indígena}

Dentro de uma classificação geral, acerca de uma tipologia determinada na utilidade, os equipamentos domésticos indígenas podem ser categorizados para descanso/trabalho; para repouso; e para guarda.

A rede de dormir, da categoria repouso, já se achava no cotidiano de tribos indígenas no período do Brasil pré-colonial. Eram produzidas em técnicas de tecelagem em algodão e fibra entrelaçados. Dependendo da trama, que podia ser aberta ou fechada, era utilizada para a pesca ou como cama e na forma de tecidos.

Além da rede, havia também outro tipo de equipamento com a mesma função utilitária, denominado catre ou leito, confeccionado com quatro paus fincados no chão, formando um retângulo, unidos por cordas e encobertos por folhas de palmeira buriti e peles. Em algumas tribos o catre ou leito era também utilizado como banco ou mesa, ou até como equipamento para guarda.

A rede, de manufatura indígena, sempre esteve presente no cotidiano de grande parte da população, principalmente no Nordeste do Brasil. É um produto de fácil aquisição e com uma utilidade bastante disseminada tanto como cama de dormir, quanto assento ou "poltrona". As redes, em suas diversas formas adaptadas, confeccionadas em tecelagem tradicional ou industrial, tornaram-se elementos comuns nas casas e no design de mobiliário brasileiro até os dias de hoje.
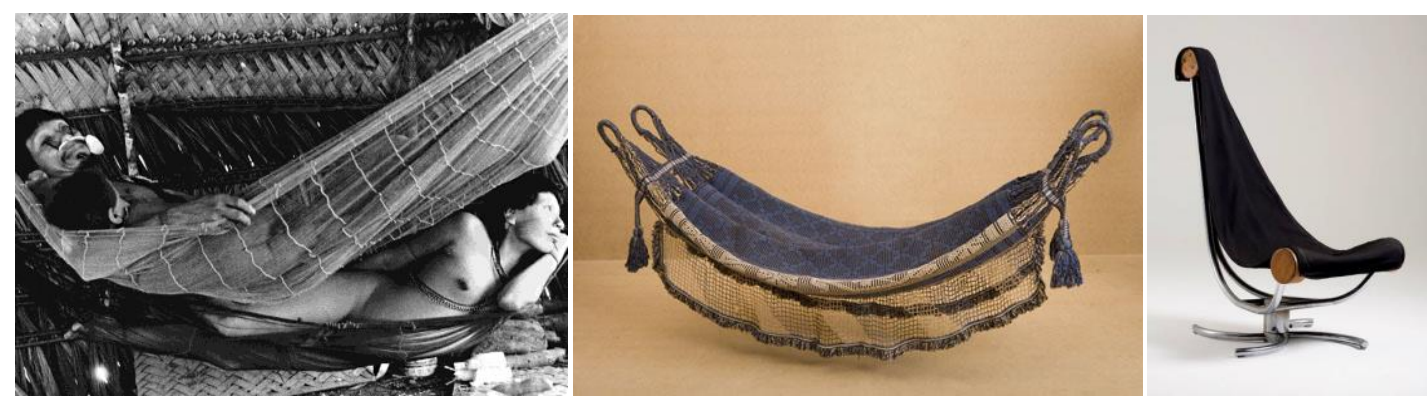

Figura 34 - Índios Matis (Amazonas) deitados na rede; rede do século XIX; poltrona Rede, Sérgio Bernardes (1975) 
Da categoria descanso/trabalho, os bancos são os maiores representantes. Os bancos indígenas, com configurações que representavam, sobretudo, elementos da fauna, traziam algumas composições mais figurativas, outras mais simplificadas. Eram feitos, em sua maioria, de toros simples de madeira usados como assento ou entalhados em uma peça só.

De acordo com Canti (1985, p. 70), os bancos "se apresentavam de vários tipos, dos simples toros de madeira utilizados como assento, aos bancos trabalhados em uma peça só de madeira, com decoração geométrica monocrômica em vermelho ou preto, alguns em forma animal".
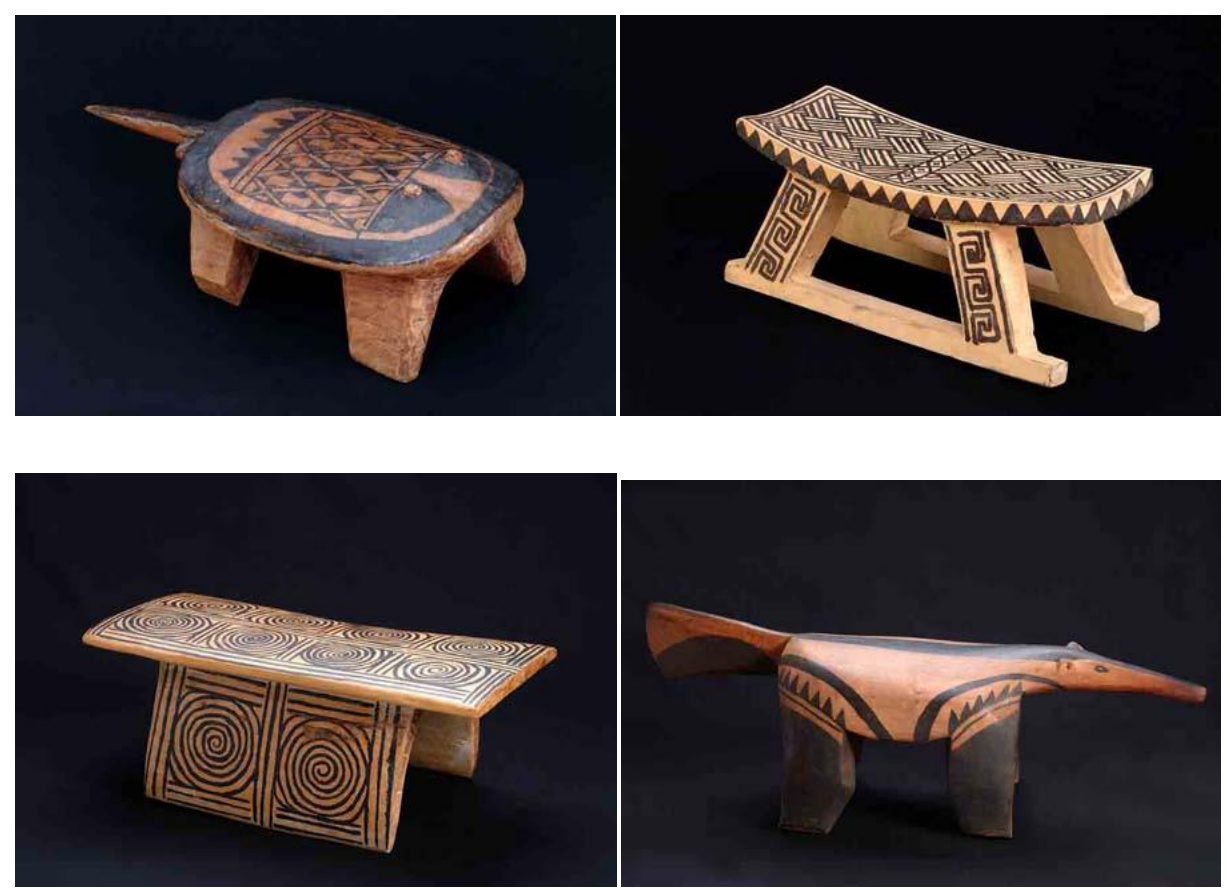

Figura 35 - Bancos indígenas

Outros exemplos de objetos e costumes de herança indígena que influenciaram os hábitos e a cultura material brasileira foram o jirau, a esteira e alguns hábitos alimentares.

A adoção do cardápio indígena introduziu nas cozinhas e zonas de serviço das moradas brasileiras equipamentos desconhecidos no Reino. Instalou nos alpendres roceiros a prensa de espremer mandioca ralada para farinha [...] que não exigia somente a prensa - pedia, também, raladores, cochos de lavagem e forno ou fogão. (LEMOS, 1978, p. 43) 
O jirau, que foi assimilado às moradias brasileiras e passou por modificações de toda ordem, assumiu novas funções. É um equipamento de legado indígena que demonstra o intercâmbio entre culturas distintas, assim como a dinâmica do processo de hibridação, como explica Lemos:

\begin{abstract}
O seu nome, conservado no linguajar do povo, não só determina as armações, digamos ortodoxas, como outros tipos de engradados horizontais, como as prateleiras profundas, por exemplo. No quintal, o jirau servia para secar alimentos resguardados dos animais domésticos, para enxugar o trem de cozinha lavado, para secar a rede de pesca e a roupa lavada e para suportar plantas trepadeiras. [...] $\mathrm{O}$ jirau invadiu o interior da cozinha e transformou-se em fumeiro definitivo. Ao ar livre, o jirau indígena era armado sobre a fogueira [...] dentro da casa brasileira, alojou-se em cima do fogão, dando ao fumeiro português a forma nativa. No jirau da cozinha roceira, como veremos mais tarde, toda sorte de mercadorias é conservada ou defumada. Outras vezes, o jirau da cozinha é baixo, é revestido de barro, como se fora uma taipa de sebe horizontal, e transforma-se em fogão - fogão de mocambo nordestino, fogão de forquilha, [...] fogão paulista dito 'de estandaque'. (LEMOS, 1978, p. 43).
\end{abstract}
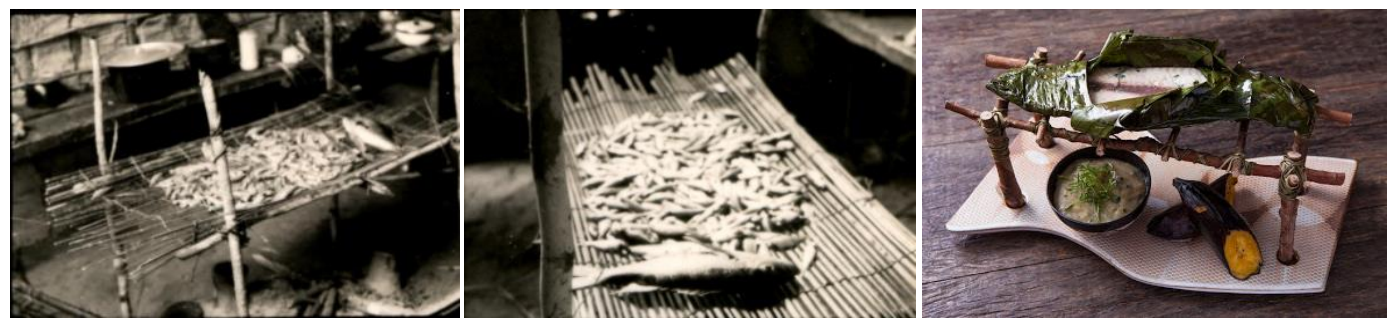

Figura 36 - Jirau indígena; e prato contemporâneo inspirado nas tradições indígenas

É apenas a partir do final do século XVI que o móvel começou a aparecer mais expressivamente nas habitações mais abastadas do Nordeste do Brasil colonial, como nas casas-grandes e capelas dos engenhos de açúcar.

\title{
4.2 Características básicas do móvel português
}

Segundo a historiografia do mobiliário, os móveis encontrados no Brasil do século XVI ao século XVIII eram peças copiadas da Europa e com poucas modificações. Lemos afirma que os móveis eram "cópia dos raros móveis vindos de Portugal, executados inicialmente em cedro e canela e, mais tarde, em vinhático, 
jacarandá e outras madeiras de lei aqui encontradas e conhecidas por sua beleza e qualidade" (LEMOS, 1989, p. 63).

Foi nesse período que houve um processo de transição e transformações significativas tanto em relação à forma quanto em relação aos meios produtivos no mobiliário português. Primeiro, ocorreram influências estilísticas vindas principalmente de outros países para, num segundo momento, desenvolver aspectos formais com características especificamente nacionais.

Na primeira fase, a grande influência que o mobiliário português sofreu teve origem em países árabes que dominaram a península Ibérica por séculos. Em seguida a influência veio das Índias e da China, devido às rotas comerciais e aos intercâmbios mercantis.

Dos árabes a influência deu-se a partir da técnica do alfarje ${ }^{24}$ e das Índias a influência é explicitada pelos entalhes recortados e vazados, baixos-relevos com preenchimento de motivos exóticos, uso de colunas internas vazadas e esculpidas, bem como de talhas douradas sobre fundo vermelho. Proveniente da China, a técnica do charão e da $\operatorname{laca}^{25}$ foi usada para pintar fundos em cores escuras e vermelhas, havendo também as aplicações em folhas de ouro e desenhos com motivos chineses.

$\mathrm{Na}$ figura 37 podemos ver como as técnicas trazidas de outras culturas pelos portugueses ainda atuam na configuração formal de peças atuais. Da técnica de marchetaria e incrustações, do uso de ilustrações figurativas aplicadas à madeira, e dos contrastes de cores e tonalidades, nos deparamos com as caixas marchetadas com motivos da fauna e flora brasileiras e o uso de cores dado pelas próprias espécies de madeiras nativas. Do alfarje, os encaixes precisos das peças do designer Maurício Azeredo. Essas técnicas constituem modos de utilização recorrente tanto no artesanato quanto no design do mobiliário brasileiro.

\footnotetext{
${ }^{24}$ Alfarje é a técnica de embutidos e encaixes, de origem árabe, caracterizada pela ausência de pregos e cola na estrutura do mobiliário. Canti (1985).

${ }^{25}$ Charão é a técnica oriental de envernizar com laca artigos de madeira ou papelão; laca é o verniz-dachina, utilizado para a obtenção do charão. Canti (1985).
} 

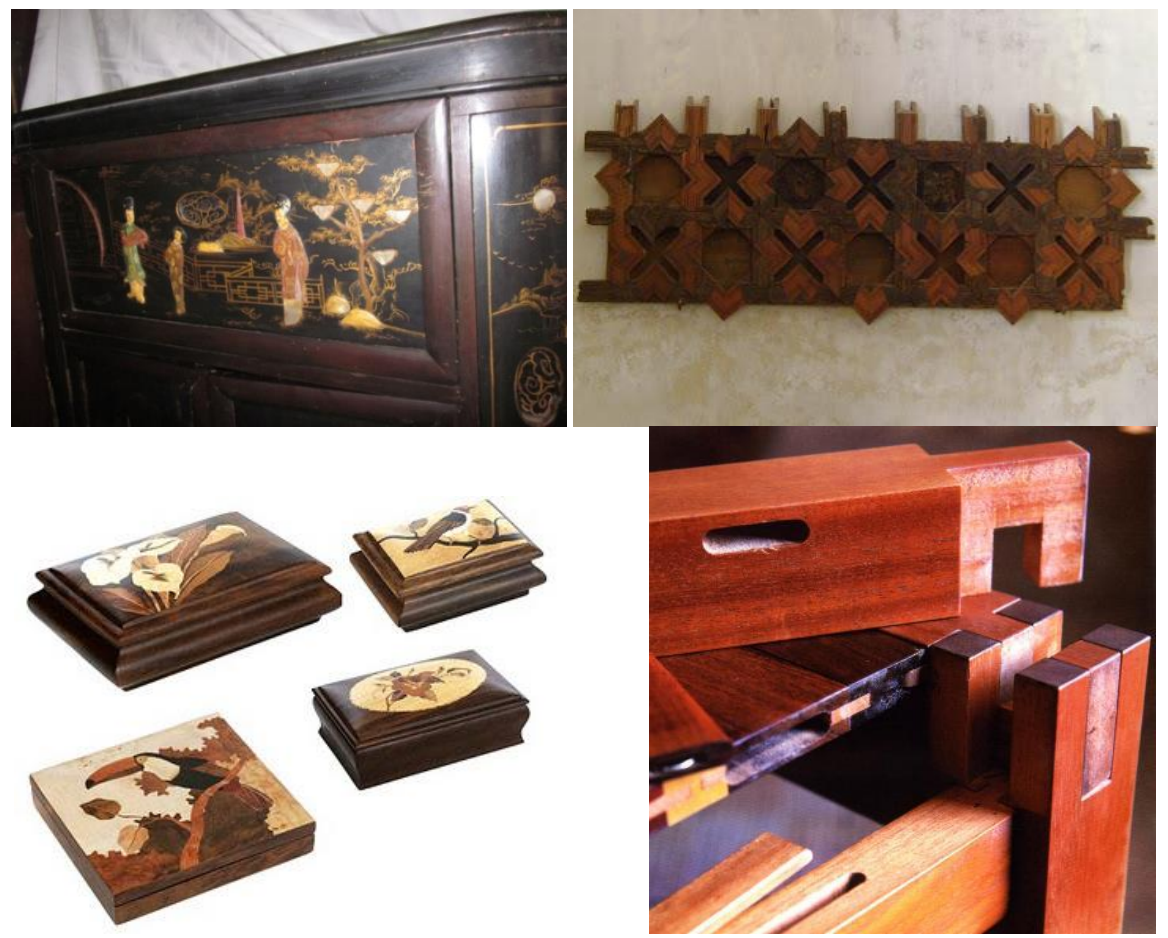

Figura 37 - Móvel com aplicação da técnica do charão (verniz negro) e incrustações - século XIX; e peça com a técnica do alfarje. Caixas marchetadas por Maqueson Pereira/PA (2012) e encaixes de Maurício Azeredo (década de 1990)

Canti afirma que do intercâmbio com a Índia e com a China nasce o móvel denominado indo-português, que tem o seu apogeu no século XVII.

Móveis com incrustações ou embutidos na técnica de alfarje são executados ainda em Portugal até princípios do século XVII; são arcas, pequenas peças moçárabes, tronos e cadeiras de braços. [...] Do intercâmbio entre Portugal e as Índias, surge, no panorama do mobiliário quinhentista europeu, o estilo indo-português. (CANTI, 1985, p. 13-14)

Para a autora, a principal característica do móvel desse período é a utilização de encaixes e espigões de madeira para substituir colas e pregos; as pernas dos móveis apresentam formas antropomórficas; e os embutidos e incrustações com marfim, ébano, madrepérola preenchem os vazios, como demonstra a figura 38. 


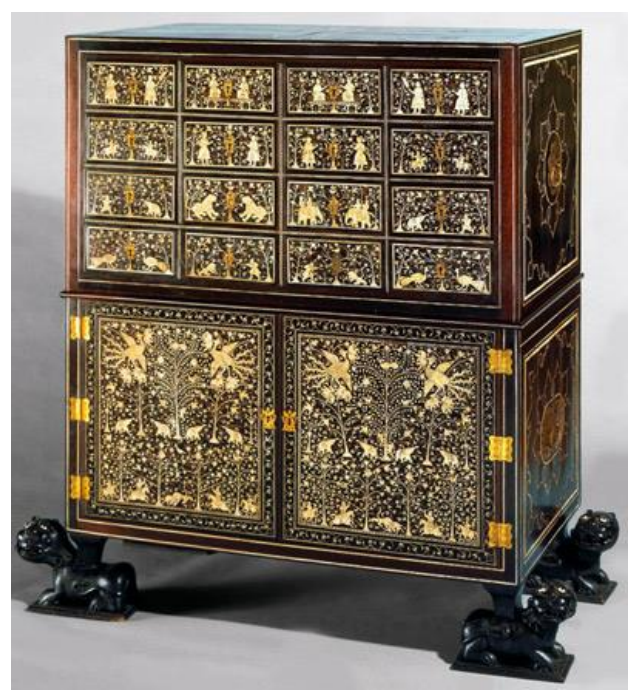

Figura 38 - Contador. Móvel indo-português, séculos XVI-XVII. Em teca, sissó, e outras madeiras exóticas, marfim natural e tinto; laca, latão.142×142×70cm. Coleção Burnay, 1936.

Em uma terceira fase, o móvel indo-português começa a sofrer influências de outra origem, como Florença, Gênova, Veneza, Flandres e Espanha. No final do século XVII, interferências vindas da Itália, principalmente as da Renascença e do período barroco, apresentaram-se com os torcidos nas peças torneadas e os entalhes decorativos.

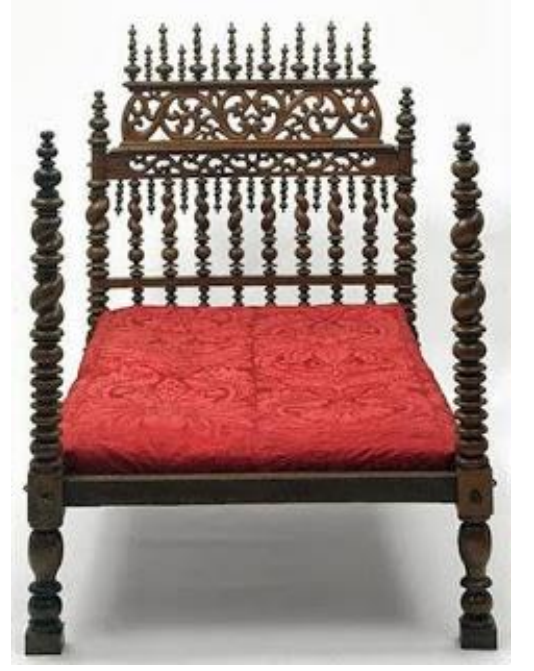

Figura 39 - Cama de bilros, estilo indo-português (séc. XVII) 


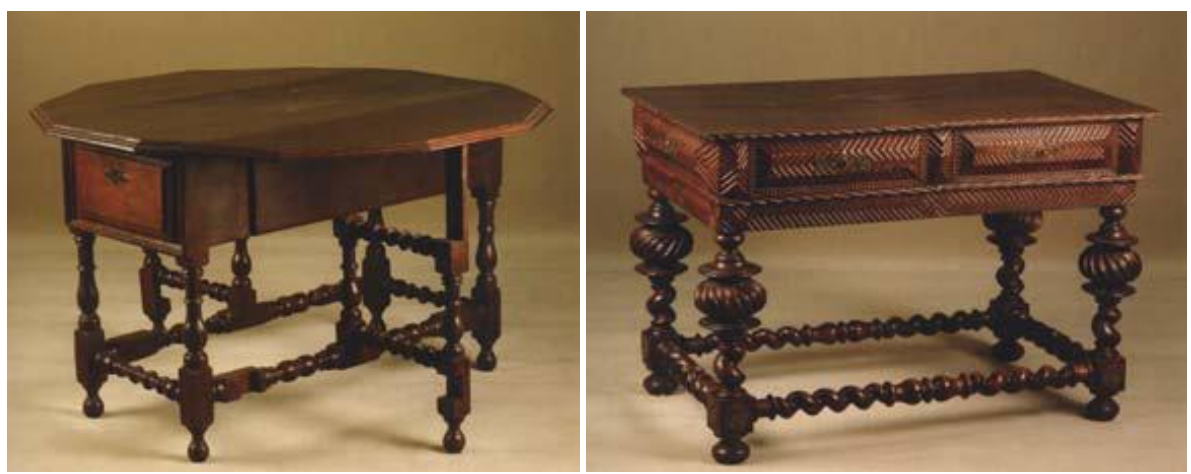

Figura 40 - Mesa de aba ou cancela, estilo renascentista (séc. XVIII); e mesa manuelina ou de "bolacha", estilo manuelino (séc. XVII)

As ilustrações da figura 40 demonstram as influências sofridas pelos diversos estilos na segunda metade do século XVII. Na mesa de aba ou cancela, tipo introduzido pelos flamengos na Inglaterra, os torcidos se transformam em figuras mais geométricas. $\mathrm{Na}$ mesa manuelina a interferência oriental está nas gavetas, laterais e parte traseira entalhadas, assim como nos torcidos das pernas.

É no século XVIII que a mobília portuguesa começa a ser descrita como estilo nacional português, portador de características genuinamente nacionais. Os móveis apresentam abundante utilização de madeira como matéria-prima, que é entalhada ou trabalhada; exibem formas mais retas, retangulares e robustas; as pernas e pés são torneados, goivados ${ }^{26} \mathrm{em}$ espinha de peixe; e os losangos são usados como elementos decorativos.

Como dito anteriormente, durante o início da colonização houve um processo de influência mútua entre a cultura portuguesa e europeia e aquela advinda dos nativos indígenas. A rede de dormir, o costume de usar esteiras para sentar-se ao chão e o uso do jirau viraram objetos e hábitos constantes nas casas dos primeiros colonos.

Segundo Lemos (1989), Canti (1985) e Costa (1975), as casas dos colonos portugueses eram discretas e simples, apresentavam uma organização bastante modesta e pouca mobília. Entre os poucos móveis executados na colônia encontravam-se camas, mesas, arcas, cadeiras e baús, além da rede de dormir. Essas características foram passadas entre as gerações e, segundo os autores, a sobriedade se manteve como um dos aspectos da casa brasileira. Em outro viés, era possível encontrar nas casas mais abastadas alguns móveis vindos diretamente da corte, como as camas de bilro, as

\footnotetext{
${ }^{26}$ Goivado é o elemento decorativo em forma semicircular reentrante, muito empregado na madeira do mobiliário seiscentista português. Podia ser vertical, espinhado ou enviesado. Canti (1985).
} 
cadeiras de sola, contadores e arcas, que possuíam desenhos mais elaborados e detalhados.

Na relação entre colônia e colonizador, foram trazidos no século XVI diversos itens de Portugal. Além de gêneros de primeira necessidade, utensílios domésticos e a mobília, vieram também mestres de vários ofícios. Os mestres em carpintaria, marcenaria e entalhe eram responsáveis pela produção da mobília local. Já nos séculos XVII e XVIII, oficiais marceneiros, torneiros, ensambladores e correeiros portugueses transferiram-se para o Brasil (CANTI, 1985, p. 83).

Outra característica bastante interessante a se destacar diz respeito ao uso da matéria-prima, a madeira. Já utilizada em abundância na história do mobiliário em geral, a madeira brasileira encontrou bastante destaque na confecção de peças. O Brasil possuía extensa floresta, fartas e variadas espécies de árvores nativas. Madeiras moles e duras, coloridas ou monocromáticas, uma fartura de características ainda não empregadas pelos europeus.

Canti sintetiza em quatro categorias utilitárias os móveis que foram incorporados nas casas brasileiras a partir do século XVII: a) móveis de guarda - caixa, caixão, baú e canastra, arca, contador, escritório e armário; b) móveis de descanso - banco, arquibanco e arca-banco ou banco com caixa, cadeira e tamborete, escabelo e tripeça, cadeira e tamborete, assentos dobradiços, entre outros; c) móveis de repouso - leito, catre e cama; d) móveis de utilidade - mesa de aba e cancela, mesa de cavalete ou bufete, mesa de pernas lira ou bufete, entre outros (CANTI, 1985, p. 91-149), como ilustradas nas figuras 41, 42 e 43.
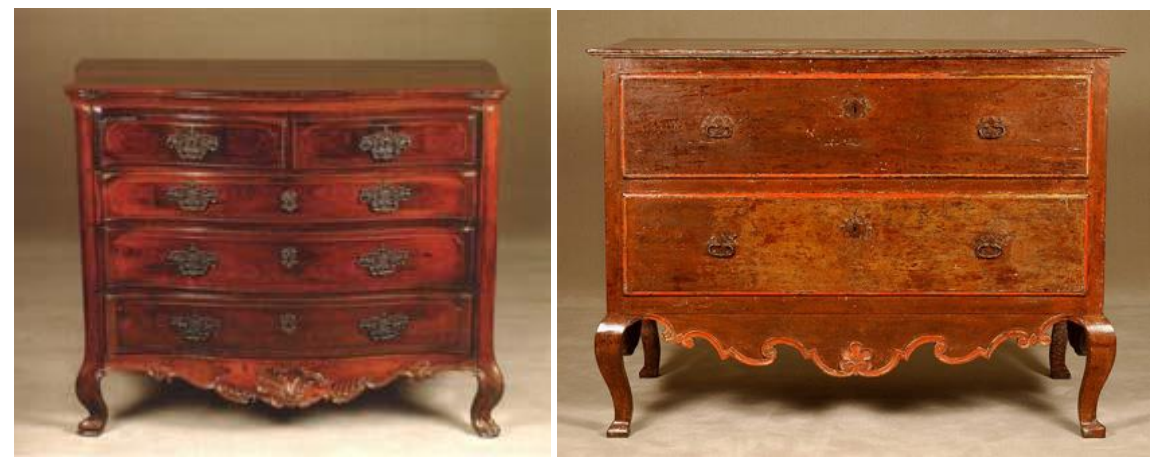

Figura 41 - Móveis de guarda. Cômoda de jacarandá, estilo D. João V (século XVIII) e cômoda rústica, estilo D. José V (século XVIII) 

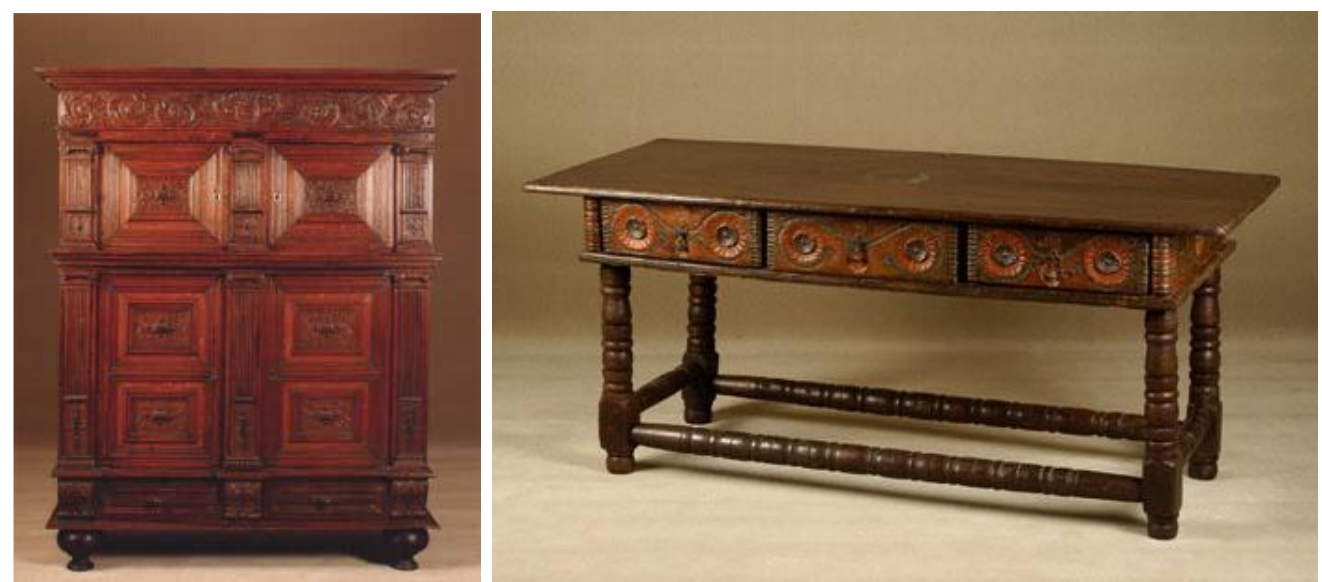

Figura 42 - Móveis de guarda e de utilidade. Armário português de carvalho, estilo nacional-português (século XVII) e bufê ou bufete campesino (século XVIII)

Ressaltam-se nas imagens da figura 43, os móveis do artesanato popular que são visivelmente mais simples do ponto de vista formal e têm um acabamento mais rústico que aqueles vindos de Portugal.

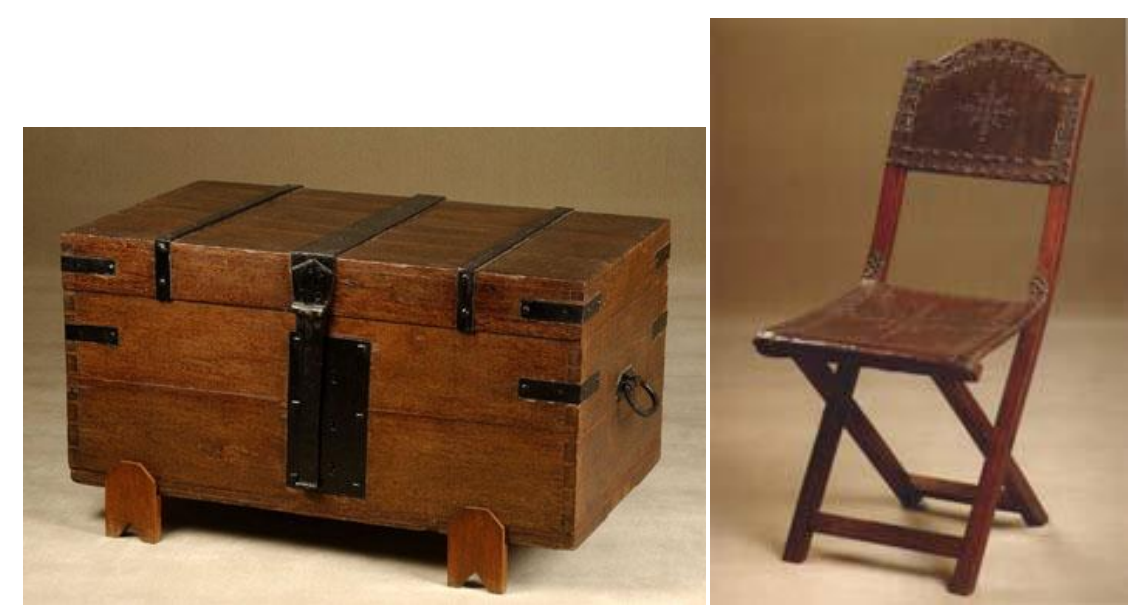

Figura 43 - Móveis de guarda e de descanso. Cofre ou baú (século XVIII) e cadeira de campanha, artesanato popular (século XVIII)

Há dois autores que fazem uma classificação acerca dos tipos de mobiliário colonial existentes no Brasil.

O primeiro é Augusto Cardoso Pinto, que categoriza os móveis durante os séculos XVII e XVIII da seguinte maneira:

a) mobiliário trazido da Metrópole e que, portanto, é genuinamente português; 
b) mobiliário feito no Brasil por artistas vindos de Portugal ou já aqui nascidos, mas formados nas oficinas dos primeiros, segundo os modelos ou pelos moldes tirados fielmente desses modelos, vindos da Metrópole; e isto é ainda mobiliário português;

c) mobiliário em que, por falta de modelos, necessidade de variação, natureza das encomendas ou outras razões, se introduziram alterações nas formas e na decoração; e este é já mobiliário luso-brasileiro;

d) mobiliário em que intervieram influências estranhas ou se introduziram modificações estruturais, umas e outras não verificadas em Portugal, inclusive as espécies que, embora no estilo português, não têm congêneres em Portugal; e este é já mobiliário brasileiro ou pelo menos luso-brasileiro;

e) mobiliário de caráter semi-rústico, feito nas missões ou em locais afastados dos centros populacionais, por artífices improvisados ou de fraca aptidão, para suprir as necessidades de instalação, em que, por falta de modelos e da gramática ornamental de que dispõem os profissionais, houve que resolver empiricamente os problemas de construção e criar motivos decorativos, tirando-os diretamente da fauna e da flora; este é mobiliário lidimamente brasileiro. (PINTO apud CANTI, 1985, p. 93)

Canti (1985) assinala que a classificação do item d) possui uma discordância conceitual. A autora diz que a caracterização das intervenções estranhas ou modificações estruturais não encontradas nos móveis portugueses e tidas como lusobrasileiras é errônea. Esclarece que, se assim fosse, os móveis portugueses que sofreram interferências dos estilos inglês, espanhol e francês seriam categorizados como angloportugueses, hispano-portugueses ou franco-portugueses, o que nunca foi admitido pelos historiadores.

Biancardi (1988, p. 6) comenta que a classificação de Pinto abrange apenas a procedência e a técnica, não fornecendo subsídios para a identificação formal. Quanto ao item classificatório d), concorda com Canti (1985). Afirma que os móveis dessa categoria deveriam ser classificados apenas como mobiliário brasileiro e não lusobrasileiro.

O segundo autor que classifica os tipos de mobiliário existentes no Brasil é Lúcio Costa (1975). Conforme Costa, que faz uma classificação por parâmetros estilísticos, divide-se em três grandes fases: a primeira, situada entre os séculos XVI e XVII, que se prolonga até o início do século XVIII; a segunda, em meados do século XVIII, considerada fundamentalmente barroca; e a terceira fase, na primeira metade do 
século XIX é resumida pela reação acadêmica e liberal principiada no fim do século XVIII.

[...] o primeiro abrange os séculos XVI e XVII e prolonga-se mesmo até o começo do setecentos; o segundo período, barroco por excelência, estende-se praticamente por todo o século XVIII; e o terceiro e último, isto é, o da reação acadêmica, liberal e puritana, iniciada em fins deste século, corresponde para nós, principalmente, à primeira metade do século XIX (COSTA, 1975, p. 139).

Na primeira fase, a produção do mobiliário no Brasil se reduz basicamente ao interior dos engenhos de cana-de-açúcar. Os móveis eram produzidos com madeira de lei por marceneiros vindos da corte para construir e entalhar os interiores de igrejas e conventos locais. Esses marceneiros contavam com a ajuda dos escravos e passaram a formar uma "indústria" caseira.

Os móveis dessa época são caracterizados por uma estrutura formal nitidamente rígida, em composições retangulares,

[...] as pernas torneadas ou torcidas, as almofadas formando desenhos geométricos, os tremidos, a ornamentação corrida ao longo das abas ou de florões marcando a amarração das tempres - tudo concorre para acentuar o aspecto construído, "tectônico". (COSTA, 1975, p. 139)

As formas curvas e arredondadas são introduzidas no desenho das peças de modo muito mais decorativo que estrutural ou de relação da proporção entre os elementos. Essas estruturas tornavam os móveis destituídos da capacidade de ofertar repouso, pois levavam a uma postura ereta e com poucas possibilidades de mobilidade.

Lúcio Costa aborda os materiais empregados na confecção dos móveis: "O material empregado era, isto sim, bem brasileiro" (COSTA, 1975, p. 135). Segundo Canti (1985), as madeiras nativas mais aplicadas eram o vinhático, o cedro, o jacarandá e a canela preta ou branca.

Na segunda fase, denominada por Lúcio Costa o período do século XVIII, imperam as características do móvel barroco português. Tais características são explicitadas pela riqueza de detalhes e entalhes. O período é iniciado pelo estilo D. João $\mathrm{V}$ e destaca o uso constante de curvas aplicadas nos pés das peças, presentes na aba do assento ou logo abaixo do corpo do móvel. Há também o uso de elementos decorativos 
em forma de conchas, folhas e feixes de plumas, típicos do período barroco e rococó como já exposto no capítulo 3.

É nesse período que ocorre também o estilo do reinado de D. José I e o estilo D. Maria I. A principal característica do primeiro estilo é encontrada nos móveis menores e mais leves, na talha rasa na madeira que substitui a talha alta e cheia, e nas amarrações, que vão desaparecendo. No segundo, encontram-se ornamentos em motivos florais, obtidos principalmente pelas incrustações, marchetaria e filetados da madeira clara sobre a madeira escura.

Segundo Canti, o móvel barroco brasileiro distancia-se da arquitetura carregada de ornatos e caracteriza-se por aspectos mais simples, utilizando-se de madeiras como imbuia, cedro, canjerana, jacarandá do litoral e da Bahia, pinho, entre outras.

[...] o estilo barroco se difunde por todo o Brasil, e suas linhas curvas vêm substituir gradualmente o estilo anterior, onde predominavam a linha reta e os torneados, o todo enquadrado em massas retangulares e rígidas. $\mathrm{O}$ estilo barroco português, mais simples e severo que o barroco corrente no resto da Europa, encontrou no Brasil, sobretudo no trabalho de entalhe, um campo vastíssimo, devido à qualidade e riqueza de nossas madeiras. (CANTI, 1985, p. 9)
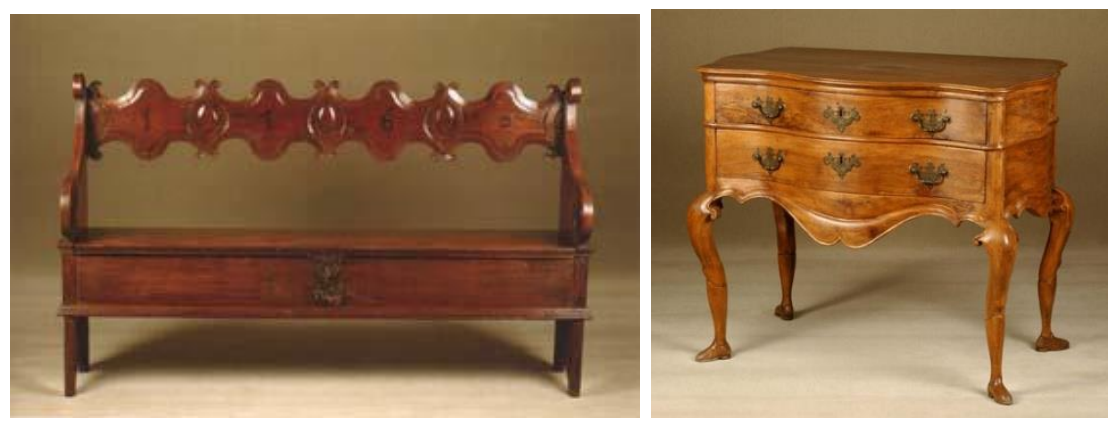

Figura 44 - Arca-banco e meia-cômoda com pernas de valete. Estilo barroco (século XVIII) Nota-se na meia-cômoda as botas que calçam os pés do valete.

Para Lúcio Costa (1975), essas mudanças são consideradas revolucionárias, pois a rigidez estrutural do período anterior passa a dar mobilidade e fluidez aos móveis.

[...] enquanto as peças dantes se formavam de quadros de aparência rígida, a composição passa a ter agora um núcleo central de onde parte - quase se poderia dizer: de onde cresce - o resto do móvel. De onde cresce, sim, porque desse ponto, ela vai se abrindo e desdobrando em ondas sucessivas, passando com agilidade de filete em filete e de uma voluta a outra, até atingir os contornos extremos da peça, para daí voltar ao ponto de partida, onde o movimento toma novo impulso e recomeça. Essa impressão de movimento e vida - em contraste com a feição estática característica do movimento anterior -, como se fosse 
organismo e não uma coisa fabricada, é o traço comum que distingue de um modo geral a produção do século XVIII. (COSTA, 1975, p. 141)

Pode-se dizer que as características formais das peças do mobiliário barroco português e brasileiro valem como aquelas das estruturas básicas conceituais do estilo barroco como um todo (ver item 3.1). Assim, a estrutura dos móveis do período torna-se mais flexível, fazendo valer a introdução do conceito de conforto.

Outra característica não menos importante é a incorporação de cores nos móveis, principalmente aqueles fabricados em Minas Gerais.

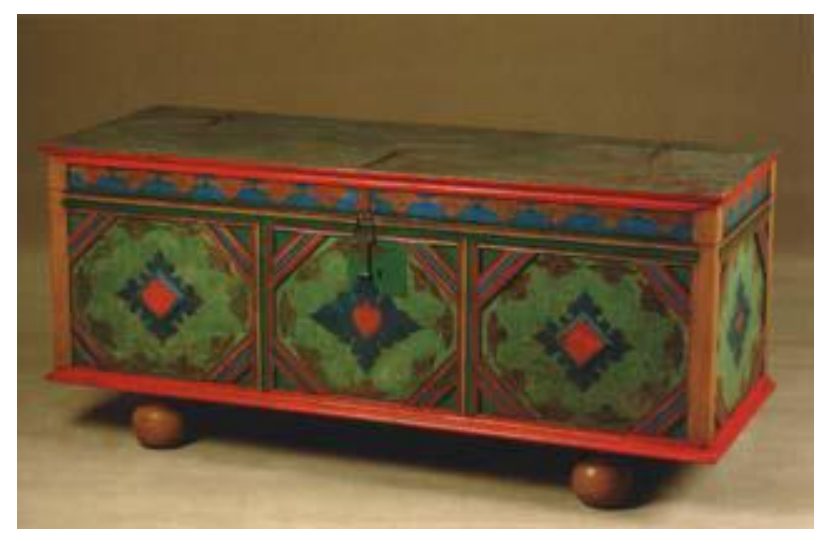

Figura 45 - Arca ou caixa colorida. Estilo barroco mineiro (século XVIII)

Já no século XIX, com a vinda de D. João VI para o Brasil, houve um aumento significativo de importação de produtos de outras partes do mundo, como Inglaterra, França, Estados Unidos, Alemanha e Áustria, diminuindo a importação dos móveis portugueses. Esse fato causou transformações significativas na produção da mobília. Artistas, comerciantes e marceneiros estabeleceram-se no Brasil.

Trazidas de fora, essas novidades foram aos poucos sendo absorvidas pelas elites brasileiras que, tomando como referência os costumes e a cultura européia, passaram a ter, no consumo de seus produtos, uma forma de ostentar superioridade financeira e destaque social. Assim, o despojamento até então predominante nos interiores das casas brasileiras mais abastadas foi sendo substituído pelo desejo de um novo padrão de moradia, no qual se incluía a aquisição de um maior número de móveis, inclusive de peças supérfluas simplesmente decorativas. (BAYEUX, 1997, p. 71)

A partir dessa prerrogativa, o móvel brasileiro sofreu diversas influências, principalmente aquelas advindas do rococó ou rocalha e do neoclássico. Desse último 
estilo, enfatiza-se a volta de linhas retas e, em parte, a redução do uso de detalhes. O estilo Luís $\mathrm{XVI}^{27}$ aparece com características formais mais simples, porém com embutidos de madeiras claras e também a utilização de talhas e aplicação em bronze. Contudo, as curvas não deixaram de ter lugar de destaque, propondo uma composição fluida juntamente com as linhas retas de desenho estático dos móveis.
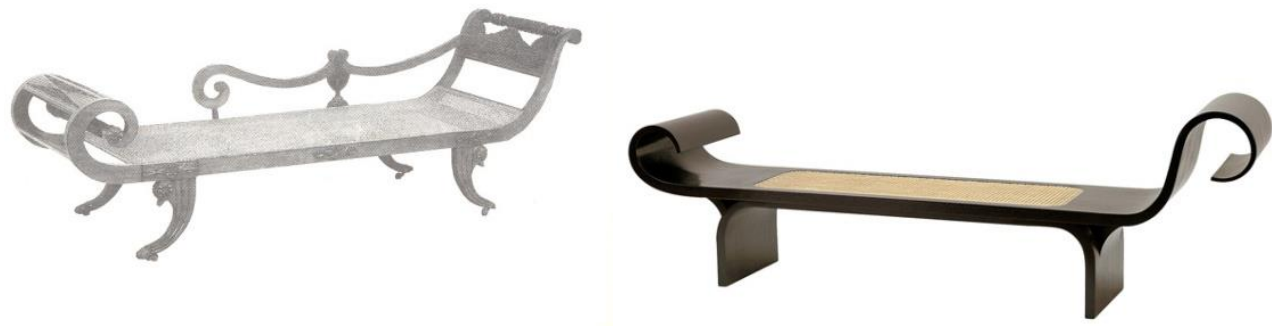

Figura 46 - Preguiceiro com uso da palhinha (século XIX);

Marquesa de Oscar Niemeyer e Anna Maria Niemeyer (1974)

O preguiceiro, assim denominado, pois segundo Mello e Souza (1999, p. 152) "A imagem da preguiça generalizada do brasileiro é bastante forte em nosso imaginário...", é um tipo de peça da categoria de descanso que foi bastante difundida no período, e sempre foi fonte de referência para arquitetos e designers desde então.

[...] é a época dos bonitos e majestosos sofás de palhinha e das mobílias de sala de visita de aspecto às vezes sóbrio, outras, pretensioso e rebuscado, em todo caso sempre formalístico. Nota-se, finalmente, na segunda metade do século, quando se generalizam, em mesas e consolos, os tampos brancos, certa tendência para a volta à linha barroca. (COSTA, 1975, p. 143-144)

${ }^{27} \mathrm{O}$ estilo Luis XVI é caracterizado por assimilar simultaneamente duas características distintas, a do estilo anterior, dentro do espírito do rococó, e a do neoclássico, estilo do momento. O estilo Luís XVI conjuga nas suas peças vários elementos opostos, criando assim uma estética própria e híbrida. 

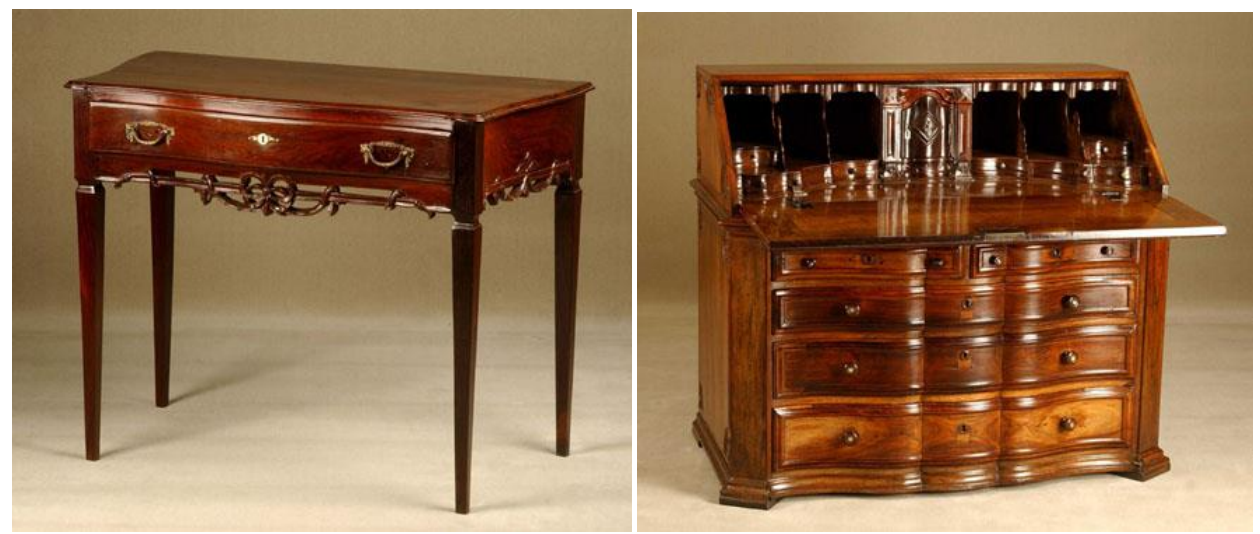

Figura 47 - Mesa de encostar D. Maria I, estilo neoclássico (final do século XVIII) e cômoda prateleira D. José I, estilo neoclássico (século XIX)

Segundo Santos (1995), o móvel colonial brasileiro destaca-se por seu caráter híbrido e pela composição eclética de seus componentes. Havia nesse período desde móveis mais sofisticados, com detalhes refinados, acabamentos e configurações mais ornamentais, aos móveis com acabamento rústico, como o catre e o banco bandeirante, representantes do artesanato popular, como ilustra a figura 48.
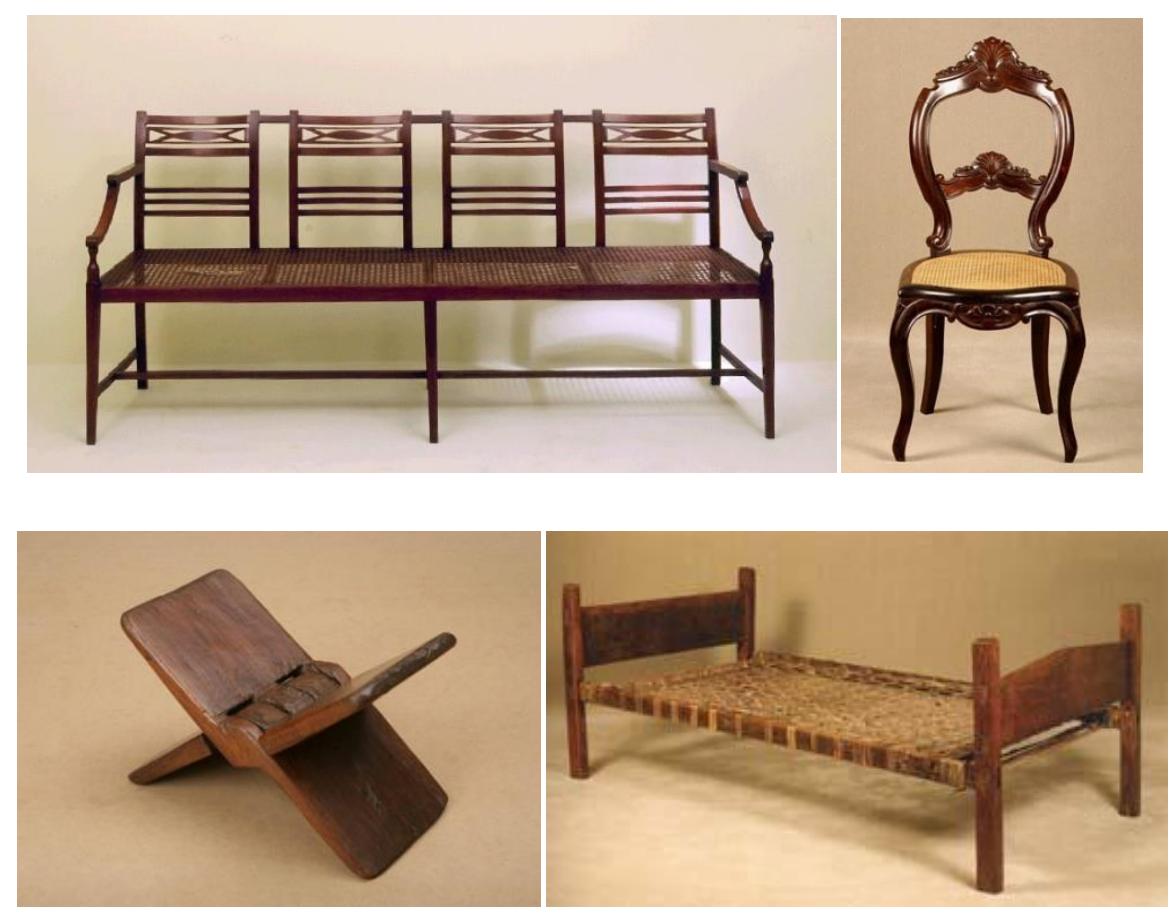

Figura 48 - Canapé Sheraton Brasileiro, estilo Sheraton (século XIX); cadeira Beranger, estilo Beranger; banco bandeirante, artesanato popular (século XIX); e cama catre, artesanato popular (século XIX) 
O catre ou catle, que influenciou o estilo de leitos da península Ibérica, é originário da Índia e da China. No Brasil, este termo se aplicava à cama estreita de solteiro, de estrutura simples e construção rústica. (MUSEU DA CASA BRASILEIRA, 2002, p. 176)

Aos poucos, foram sendo assimiladas muitas características regionais ao mobiliário. O estilo Sheraton Brasileiro foi originado a partir do inglês Sheraton e das influências da "mobília artística". Já o estilo Beranger ou Pernambucano, criado pelo marceneiro Francisco Beranger, adicionou ao estilo neorrococó e a elementos do estilo francês Império, ornamentos com motivos da fauna e flora brasileiras.

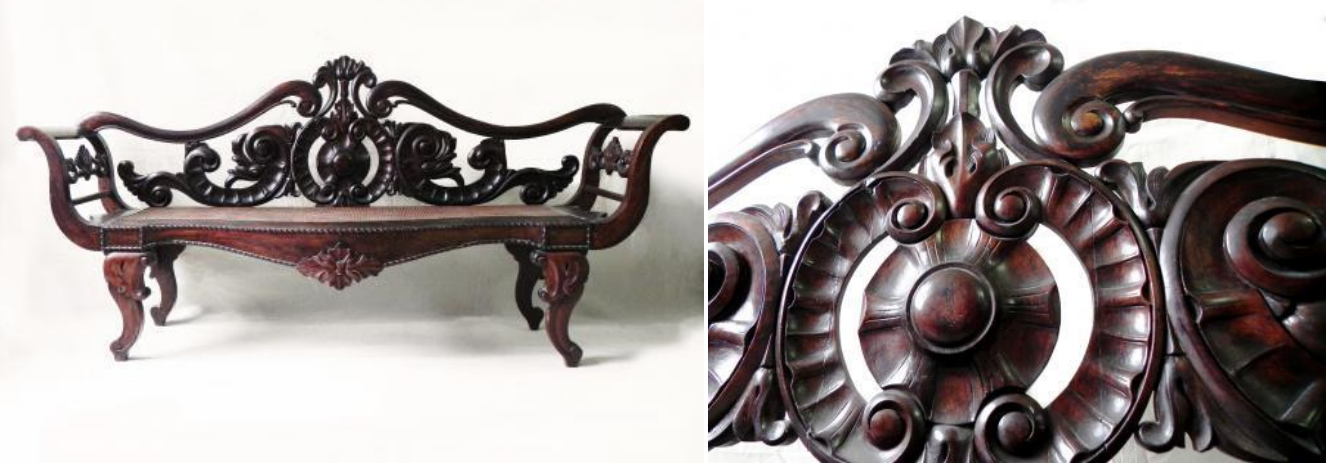

Figura 49 - Canapé Beranger e detalhe, estilo Beranger (século XIX)

A partir das importações de móveis de outros países que não apenas Portugal, a produção local também foi influenciada e intensificada por essa situação. Artistas, artesãos brasileiros e imigrantes europeus começaram a produzir a partir de tecnologias trazidas de fora. A cadeira Thonet ${ }^{28}$ foi uma grande influenciadora desse processo.

Em meados do século XIX, a produção artesanal era bastante significativa e vários estilos eram praticados. Já a partir do final desse século, a produção artesanal começou a ser substituída pelo processo de industrial. Não houve, contudo, a dissociação da tradição do fazer artesanal praticada e aprimorada pelos mais de 500 anos do uso da madeira, tampouco da experiência e habilidade dos artesãos unida à abundância dessa flora. Várias obras de artistas e designers atuais refletem esse pensamento.

\footnotetext{
${ }^{28}$ Criada por Michael Thonet, em 1859, na Áustria. Um dos primeiros modelos fabricados em série que utilizou a técnica da madeira envergada e o assento de palha.
} 
A herança do uso da madeira e suas técnicas, tão amplamente composto pela riqueza das influências advindas das várias culturas trazidas pelos portugueses; os hábitos culturais e sociais dos diferentes povos que já habitavam e que começaram a habitar o país; e as mesclas, combinações, sobreposições, justaposições de formas, estilos e técnicas construtivas que se fizeram presentes na produção e na inserção do mobiliário na realidade do cotidiano colonial, são práticas evidentes que marcaram e influenciaram fortemente o desenvolvimento do design do mobiliário, bem como se fizeram referência simbólica no imaginário do povo brasileiro.

Estas manifestações são tidas como de grande alcance simbólico, e submetemnos, de forma irreversível, à subjetividade e seleção que o processo de memória solicita. Remetem-nos a um passado enraizado de grande referência. Para tanto, defendemos o princípio de que sempre houve uma busca às tradições, em que representações emblemáticas do passado, igualmente simbolizam o presente; em que verdadeiros resgates são repletos de múltiplos significados e intenções; em que o presente comemora o passado de forma harmônica e livre, aberto à experiência simbólica e à experiência emocional. 


\section{O DESIGN DE MOBÍLIA NO BRASIL}

As ideias gerais do modernismo europeu que tinham como intuito acompanhar o empenho progressista, tecnológico e econômico advindos da civilização industrial se depararam com um Brasil também em fase de ebulição. A renúncia aos modelos clássicos; a aproximação entre as artes "maiores" e suas aplicações à produção econômica; e a procura por uma linguagem singular que expressasse os novos métodos de produção foram incorporados às propostas brasileiras.

A busca por uma racionalidade advinda da relação de causa e efeito, em que são feitas deduções lógicas a partir de exigências objetivas, que era o grande mote do funcionalismo na arquitetura e da produção industrial de objetos, aloja-se no discurso brasileiro procurando uma sintaxe entre as linguagens. Arquitetura, artes e desenho industrial procuram aproximar-se. A partir dos anos $30,[\ldots$.$] com o desejo de modernização geral do país,$
configurou-se um conjunto de fatores que desempenhou importante papel no
processo de modernização da mobília. (SANTOS, 1995, p. 21)

Até início da década de 1920, a cultura brasileira permanecia vinculada ao modelo europeu do século anterior. De acordo com Santos (1995), o Brasil foi incluído no espírito de modernização europeia por meio da Semana de Arte Moderna de 1922. Essas experiências modernistas foram as raízes que proporcionaram a reformulação dos espaços, dos programas arquitetônicos e do próprio móvel brasileiro.

Os móveis produzidos até a metade do século XX eram fabricados sob encomenda efetuada ao Liceu de Artes e Ofícios e por marcenarias que surgiam conforme a demanda que crescia. Os móveis mantinham o estilo eclético, misturando estilos de diversas épocas e eram consumidos pela aristocracia e pela burguesia urbana no Brasil.

Cabe recordar que o Brasil não sofreu transformações políticas e sociais expressivas até a metade do século XX, ao contrário da Europa, que assistiu a uma revolução para que a burguesia ascendesse ao poder. A elite agrária, representada pelos barões do café, determinava os rumos políticos e econômicos brasileiros. Esses cidadãos moravam nas cidades e estavam expandindo seus negócios para o setor industrial, que aos poucos ia se estruturando e que tomou força a partir da década de 1950, com os planos de crescimento e progresso de Juscelino Kubitschek. 
Até a década de 1930, o Brasil manteve-se na situação de país agrário, exportando matérias-primas e importando produtos manufaturados. É a partir de então que os primeiros sinais internos de industrialização e a emergência de uma burguesia urbana acontecem.

\subsection{0 móvel moderno no Brasil}

O Brasil teve sua primeira experiência junto à produção seriada, ou seja, dedicada ao consumo popular, durante o período da $1^{\text {a }}$ Guerra Mundial, quando Celso Martinez Correa (1884-1955) desenhou a primeira linha de móveis em madeira vergada na década de 1920. Os móveis, batizados de Patente, eram formalmente inspirados nos móveis Thonet, e tinham como discurso a simplicidade e a inteligência do desenho. A proposta era desenvolver móveis de produção racionalizada para obter preços mais acessíveis. Outro exemplo a ser dado é a marca Cimo - Companhia Industrial de Móveis -, criada pela família Zipperer, em 1921. Eram móveis também feitos de madeira vergada a partir de moldes padronizados que permitiam agilidade de produção. Os móveis Cimo contribuíram para disseminar o conceito da marca: simplicidade, funcionalidade e economia.
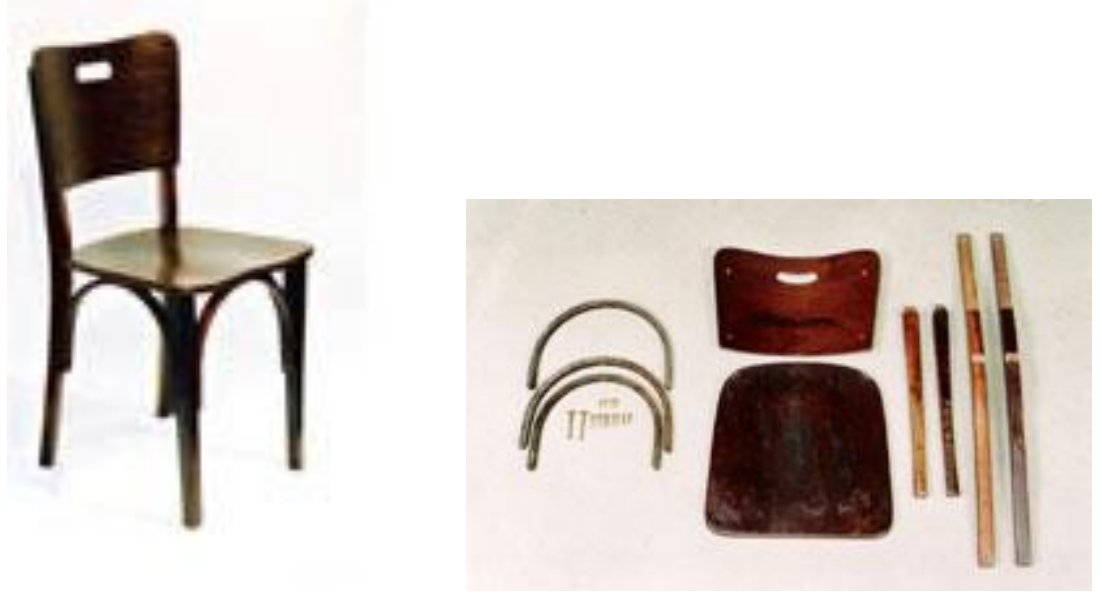

Figura 50 - Cadeira Cimo, décadas de 1920 e 1930 - simplicidade, funcionalidade e economia

Assim, a história do móvel no Brasil está dividida em duas etapas. A primeira, até a década de 1930, quando os móveis seguiam a cópia dos estilos do século anterior e a tradição colonial; e a segunda, depois da década de 1930, com a manifestação da arquitetura moderna e o afloramento das ideias modernistas surgidas no movimento de 
1922. Tanto Santos (1995) quanto Bayeux (1997) asseveram que esses fatores foram fundamentais e serviram de base para a construção do processo de modernização dos móveis no Brasil.

De fato, podemos dividir a história do móvel moderno no Brasil em duas fases bastante distintas: antes e depois de 30. Antes de 30, seguindo a tradição colonial, o que imperou foi a cópia dos velhos estilos, a cartilha foi eclética, misturaram-se aos luíses e marias o nosso colonial, o barroco, o inglês e, até mesmo, o árabe, que aqui chegou de segunda mão, via Portugal. A partir dos anos 30, com a emergência da arquitetura moderna, com a ressonância e o assentamento das principais idéias e polêmicas levantadas pelo Modernismo no âmbito da literatura e das artes plásticas, do decênio anterior, enfim, com o desejo de modernização geral do país, configurou-se um conjunto de fatores que desempenhou importante papel no processo de modernização da mobília brasileira. (SANTOS, 1995, p. 21)

O arquiteto russo Gregori Warchavchik (1896 -1972), o suíço John Graz (18911980), o lituano Lasar Segall (1891-1957) e o brasileiro Flávio de Carvalho (1899 1973) são considerados os pioneiros do desenho moderno do móvel no Brasil. Seus desenhos seguem tendências internacionais das artes decorativas - como o estilo Art Déco de John Graz - que serviram como instrumento de propagação de um estilo internacional: ausência de ornamentos e linhas puras e retas. Tais tendências foram referência para a modernização das linhas gerais do mobiliário brasileiro. Esses representantes eram, em sua maioria, estrangeiros.

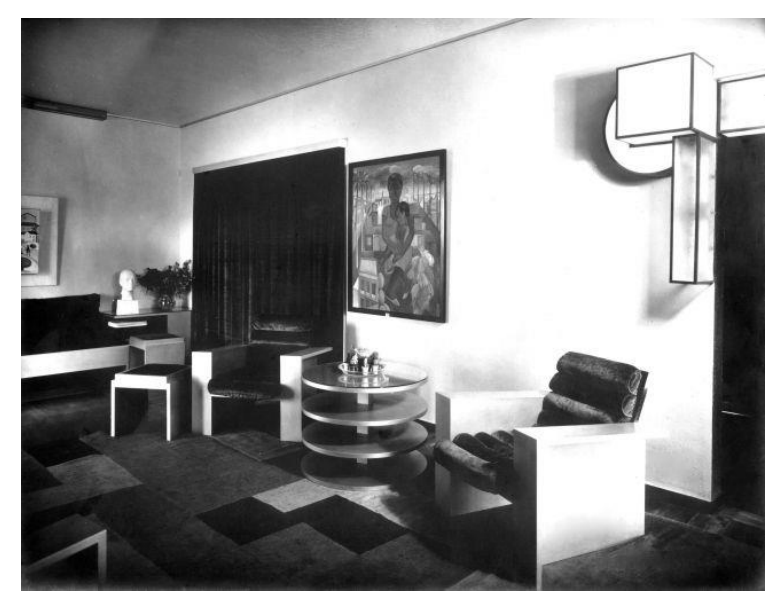

Figura 51 - Sala de estar de 1930, com móveis e objetos desenhados por Warchavchik 
A falta de uma classe burguesa consumidora tornou as iniciativas inovadoras no desenho do móvel importantes em seu caráter pioneiro, propostas por vários arquitetos e designers $^{29}$ das décadas de 1920, 1930 e 1940, contudo não representaram uma possibilidade efetiva de modernização dos interiores domésticos no Brasil desse período.

De acordo com Santos (1995), a atitude subordinada da mulher na composição da sociedade brasileira; a ausência de construções modernas que pudessem acolher os móveis de desenho moderno com coesão formal, como determinava a corrente moderna da arquitetura; e a maneira como eram produzidos, formam um elenco de razões para a não aceitação pela sociedade dos móveis modernos, não apenas aquelas baseadas na questão do desenho inovador. Eram móveis com desenho moderno e que integravam a vertente que visava à industrialização em série, porém eram produzidos por marcenarias para um único cliente ou para poucos ${ }^{30}$.

[...] também é decorrência da divisão sexual do trabalho, que atribuía ao homem funções produtivas externas, e à mulher tudo o que diz respeito à programação e à manutenção da interioridade privada. Por isso os cuidados com a decoração, a ornamentação e com o próprio móvel eram considerados "affaire" feminino. (SANTOS,1995, p. 26)

Em meados da década de 1940, ecoam conceitos de alguns profissionais que instauraram um momento de transição pautado por uma revisão das influências externas e pela valorização das formas e materiais genuinamente nacionais. Os representantes deste processo são Joaquim Tenreiro (1906 -1992) e Lina Bo Bardi (1914 - 1992).

Entre 1941 e 1942, Joaquim Tenreiro abriu a firma Langenbach \& Tenreiro Móveis e Decorações, iniciativa pioneira na produção de artesanato em série, especializada em móveis de desenho moderno. A obra de Tenreiro é uma grande representante para a história do móvel nacional, pois não só representa o apuro estético na habilidade com a madeira, como resgata o uso de fibras e da palhinha como materiais brasileiros. Nessa época, até o fechamento da empresa em 1968, Tenreiro manteve-se afastado da indústria porque não acreditava na existência de um desenho industrial no Brasil.

29 Nomes como Warchavchik, Segall, Lina Bo Bardi, Tenreiro, entre outros, formam a primeira turma preocupada com a renovação do desenho dos móveis no Brasil.

${ }^{30}$ Com exceção dos móveis da marca Cimo e da cama Patente. 
Pela afinidade com as nossas tradições portuguesas, pelo seu talento artístico e pelo profundo conhecimento da matéria-prima com que trabalhava, Tenreiro pode explorar todas as possibilidades da madeira, sua organicidade, sua maleabilidade, as cores e a textura de suas fibras, extraindo dela formas que, finalmente, nos remetiam às nossas raízes culturais. Recuperando o uso de materiais como o jacarandá e a palhinha e atribuindo-lhes uma nova linguagem marcada pela eliminação do supérfluo, seus móveis são formalmente leves, funcionais e caracteristicamente brasileiros. (BAYEUX, 1997, p. 96)
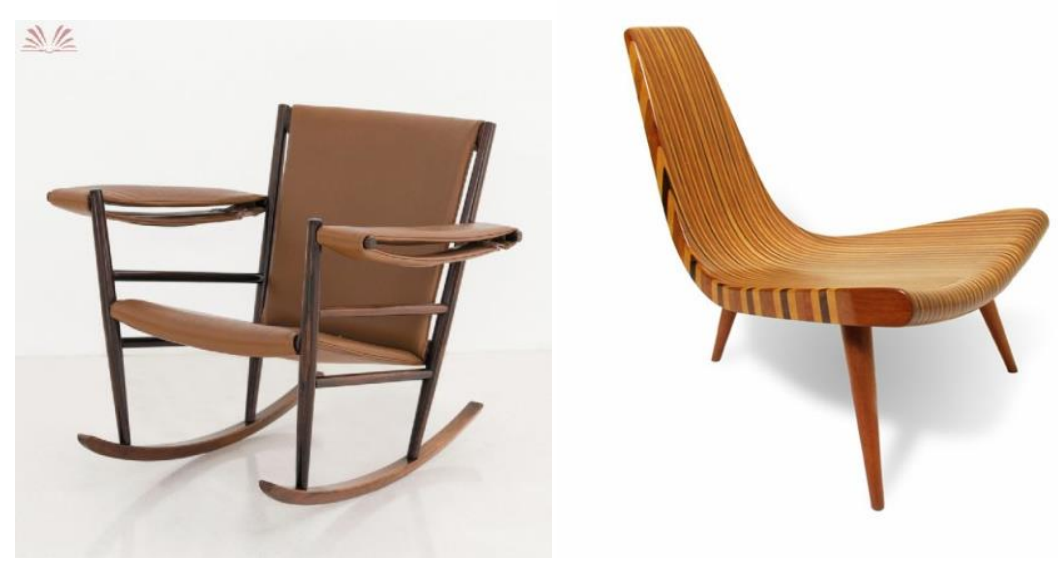

Figura 52 - Joaquim Tenreiro. Cadeira de balanço, em jacarandá da Bahia e assento em couro, 1947; Cadeira de Três Pés, em imbuia, pau-marfim, jacarandá, roxinho e mogno, 1947

Lina Bo Bardi (1914 - 1992), Giancarlo Palanti (1906 - 1977) e Pietro Bardi (1900-1999) também efetivam uma das primeiras experiências de produzir móveis em série. Fundam em 1948 o Studio Palma e a Fábrica de Móveis Pau Brasil. A experiência não foi de todo satisfatória, pois os desenhos de móveis realizados por eles eram rapidamente copiados por outros fabricantes e lançados no mercado a preços mais baratos, impossibilitando que os próprios autores se tornassem competitivos. Por esse motivo deixaram de projetar para a produção seriada.

É importante salientar que a proposta era a de que os objetos apresentassem uma pesquisa de novas técnicas construtivas, novos materiais e acabamentos, e uma nova linguagem que propunha produtos baseados numa pesquisa da cultura e das raízes brasileiras. Fizeram experimentações com materiais incomuns no mobiliário, como a madeira compensada, utilizada de forma explícita como estrutura, e o uso de lona, couro e até de tecido de chita nos assentos. É fato que a obra de Lina, mais especificamente, tornou-se referência para o mobiliário moderno, com uma linguagem entrosada com as nossas raízes culturais, enquanto representação dos elementos da cultura popular. 

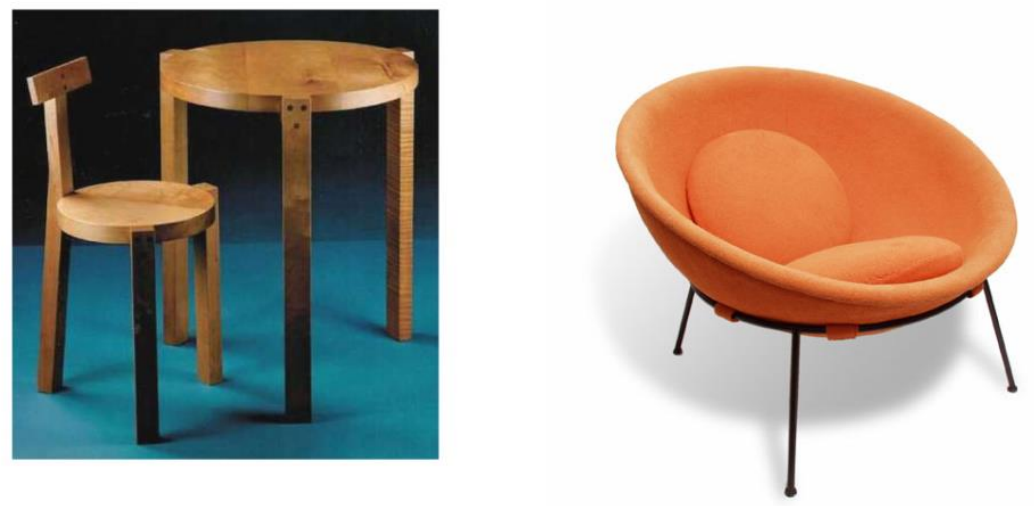

Figura 53 - Lina Bo Bardi. Mesa e cadeira Girafa, 1987;

Poltrona Bowl (Bardi's Bowl), década de 1950

É interessante destacar o vínculo que há entre a produção industrial do móvel moderno com a arquitetura moderna brasileira. O móvel moderno conseguiu passar de uma produção reduzida e artesanal para uma produção seriada a partir da década de 1950, quando houve uma aceitação e reconhecimento da arquitetura moderna pela sociedade brasileira.

Alguns autores afirmam que a renovação estética do período se fundamentou em função de outros dois aspectos. O primeiro teve relação com os novos rumos políticos do país; o segundo foi o Concretismo.

[...] o neo-positivismo político-econômico do governo e $\mathrm{o}$ concretismo, uma proposta estética de racionalização e socialização da arte. [...] o concretismo foi um movimento de intelectuais e artistas que tinham contato frequente com os acontecimentos políticos, científicos, culturais e artísticos da Europa, em particular com o Construtivismo e o Neo-Plasticismo, que parecem ter fornecido a célula geradora do movimento brasileiro. O programa do Concretismo defendia o desenvolvimento de uma linguagem geométrica que provesse a união entre arte e produção industrial. (BOMFIM, 1998, p. 122)

Outro fato a ser destacado foi a interrupção das importações de produtos industrializados devido aos problemas trazidos pela Segunda Guerra Mundial. Os profissionais, na sua maioria brasileiros, começam a pensar em um desenho de móvel moderno, compatível com uma nova sociedade brasileira e associado à industrialização. 
Dedicam-se ao desenho de um móvel que pudesse transmitir o "jeito brasileiro" de ser e morar, lançando mão de materiais nacionais.

\begin{abstract}
Embora os designers brasileiros não deixassem de acompanhar as inovações do design dos principais centros europeus, durante esse tempo de amadurecimento, muitos deles dedicaram-se à pesquisa de formas ligadas às nossas tradições culturais e à exploração das possibilidades de nossos materiais, criando soluções originais mais de acordo com a realidade, as condições, a tecnologia, o clima e o cotidiano do brasileiro. Pode-se dizer que desse processo resultaram peças em que a linguagem e a técnica modernas se aliaram às características nacionais, contribuindo, assim, para a caracterização de um design brasileiro. (BAYEUX, 1997, p. 96)
\end{abstract}

Essa peculiaridade no design do móvel brasileiro nos faz entender que, ao contrário das propostas modernistas e funcionalistas em que a linguagem deveria ser universal, entendida por todos, e que o objeto deveria ser autônomo em sua forma e em sua função, no Brasil há uma procura pelo particular, pelo cultural, pelas "raízes do povo".

Acreditamos que, entre tantas outras, essa ação venha acompanhada justamente pelas várias influências já estabelecidas e arraigadas na cultura brasileira. O que nos leva a considerar que, como dito anteriormente, são manifestações de grande alcance simbólico que já haviam sido apropriadas pelo povo e foram desenvolvidas e exploradas pelos profissionais.

Para Bayeux, a euforia do "desenvolvimentismo" foi um momento fértil para a difusão do mobiliário moderno no Brasil.

Nas décadas de 1950 e 1960, segundo Santos (1995), o pensamento moderno já estava difundido na sociedade brasileira. Nessa fase surgiram representantes como Sergio Rodrigues (1927-2014), além de indústrias como a Móveis Preto e Branco (1950), a L’Atelier (1955), Móveis Z (1950), Unilabor (1954) e, em especial, a Mobília Contemporânea (1955) de Michel Arnoult (1922-2005), entre outros tantos que contribuíram com o novo desenho e também com a produção industrial racionalizada do móvel.

A Unilabor - Indústria de Artefatos de Ferro, Metais e Madeira Ltda., de Geraldo de Barros, e a Fábrica de Móveis Z - Zanine, Pontes \& Cia. Ltda., de Sebastião Pontes e Zanine Caldas, eram empresas que produziam móveis para a classe média e tinham o objetivo de racionalizar a produção com o máximo aproveitamento de matériaprima. 
Já as fábricas Móveis Preto e Branco, de Carlos Milan, Miguel Forte, Plínio Croce, Roberto Aflalo e Chen Hwa, e a L’Atelier, de Jorge Zalszupin, tiveram seus trabalhos direcionados a partir da produção artesanal com vistas à racionalização industrial: móveis de design racionalista e apurado acabamento artesanal.
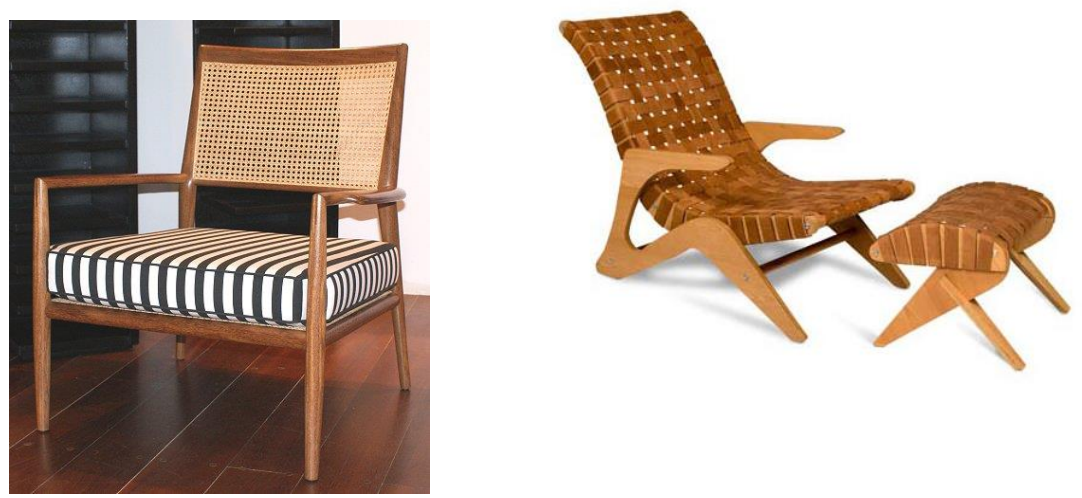

Figura 54 - Poltrona MF5 com estrutura em madeira e encosto de palhinha - Móveis Preto \& Branco; e espreguiçadeira, de madeira compensada e assento e encosto de fita plástica - Móveis Z - 1949

Michel Arnoult, com a experiência da Mobília Contemporânea, é considerado atualmente o mais inovador em propostas para a produção industrial de móveis no Brasil nas décadas de 1950 e 1960. Essa é uma fase no Brasil em que a indústria se firmava, bem como o potencial de consumo da classe média, para a qual a sua produção era voltada. Reproduzia a mobília tradicional - cama, armário, mesa e cadeiras - e atendia às necessidades da habitação desse usuário, contudo acrescentava o que era mais inovador: as peças eram moduladas, inspiradas na teoria do "átomo construtivo" $31 \mathrm{em}$ que se permite uma combinação construtiva por meio de poucas peças, favorecendo, assim, o padrão industrial. Ao propor conceitos como flexibilidade, modularidade e simplicidade de montagem e desmontagem, Michel Arnoult pretendia que o usuário recuperasse em parte o domínio sobre os móveis, com liberdade de escolha e de disposição no ambiente. Proposta um tanto quanto paradoxal, se comparada aos propósitos basilares do modernismo internacional, que exaltavam a autonomia funcional

31 O átomo construtivo foi um princípio utilizado por Konrad Wachsmann: "Um, no máximo dois elementos (um segmento e uma articulação nodal) que permitem qualquer combinação construtiva." (ARGAN, 1992, p. 279). 
do objeto. É uma racionalidade que se transforma em emoção, já que permite o jogo e a fantasia.

Michel defendia que o objeto móvel não deveria ser um elemento fixo, um "prestador de serviços" dentro da casa, mas aquele que possuísse uma relação mais amigável com seu usuário. Apesar de ter uma linguagem formal extremamente racionalizada baseada na ordenação industrial - que, diga-se de passagem, era a linguagem que foi incorporada aos produtos da época -, a proposta dos móveis de Arnoult tinha um apelo racional e emocional extremamente forte: por um lado, a limpeza e racionalidade formal; por outro, as possibilidades de intervenção dos usuários.

De acordo com Folz (2003), no início de 1970, Elvira de Almeida propôs uma interessante experiência de construção de móveis ao INOCOOP-SP. ${ }^{32}$ A proposta era a produção de móveis por cooperados, visando à autoconstrução - os próprios integrantes da cooperativa fabricavam as peças, utilizando painéis de madeira. O projeto desses móveis visava o uso e um dimensionamento mais adequados à habitação, e tinha em vista as necessidades de cada usuário.

A experiência de Elvira de Almeida, se comparada à de Michel Arnoult, é considerada mais inovadora, pois fez do habitante um aliado das decisões sobre suas próprias necessidades, um co-autor. Obviamente foi uma produção calcada em preceitos como modulação, racionalização e até uma provável seriação. Para a época, tanto a proposta de Arnoult, quanto a de Almeida, foram projetos extremamente inovadores e transformadores, pois reduziram a enorme distância entre o usuário e o objeto, sugerida pela produção em série.

${ }^{32}$ INOCOOP - Instituto de Orientação às Cooperativas Habitacionais - 1966. 

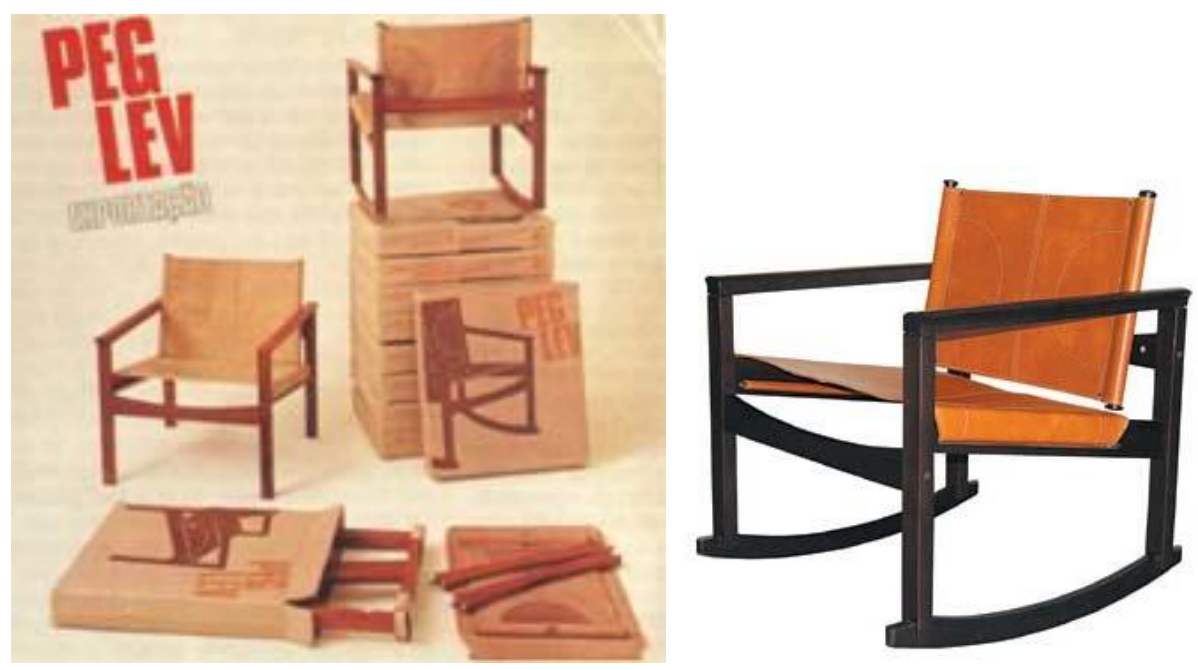

Figura 55 - Michel Arnoult, Linha Peg-Lev . Desmontável, em pau-ferro, com assento e encosto de couro natural, 1972

Já por outra perspectiva, Sergio Rodrigues trabalhou na vertente das questões relacionadas ao nacionalismo e sua relação com a cultura popular brasileira. Para Rodrigues, os móveis deveriam ser portadores de uma linguagem que representasse os valores culturais da terra. O maior exemplo desse conceito é a Poltrona Mole, reconhecida internacionalmente como representação legítima da cultura brasileira, tanto pelo uso de materiais "nativos" como o jacarandá e o couro, quanto pelo seu desenho peculiar e despojado. Com essa proposta Rodrigues acaba por lançar o que se denominou de "estética da grossura", uma estética refinada baseada muito mais no aspecto perceptivo que material, e cuja característica "grossa" se tornou uma de suas qualidades mais distintivas. Nessa época houve: “[...] maior ênfase no uso dos materiais brasileiros, maior preocupação com as formas do móvel vernacular; enfim o móvel se orientou por um certo 'estilo nacional'”(SANTOS, 1995, p. 124).

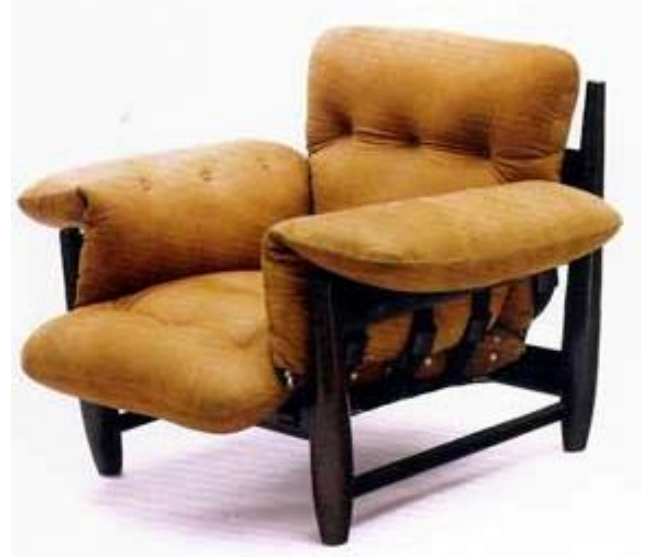

Figura 56 - Poltrona Mole, Sergio Rodrigues, 1957 
Para Santos (1995), a proposta moderna tornou-se uma alternativa ou uma solução para o crescimento das cidades brasileiras com os apartamentos em prédios residenciais. Localizados em bairros nobres das grandes cidades, ofereciam linhas arquitetônicas modernas e redimensionavam os espaços da residência: as salas, cozinhas e áreas de serviço foram compactadas. Nesses novos ambientes, a mobília utilizada não era mais respaldada. Pelo desenho, pela dimensão e em alguns casos pela função, o móvel de estilo, herdado dos pais e avós, não ocupava mais o papel de até então. Além da questão do dimensionamento dos ambientes, esses móveis também não funcionavam com relação aos novos equipamentos que foram se incorporando à casa. Eletrodomésticos como televisão, aparelhos de som, batedeiras, liquidificadores e muitos outros começaram a ser comuns nos lares.

A rigidez da distribuição do espaço interno e o congestionamento de mobiliários que ainda conservavam dimensões e tipologias tradicionais eram problemas enfrentados pelos usuários dessas habitações.

Brosig (1985) observa que o problema enfrentado pela população de baixa renda era compartilhado com a classe média da época: os dois tipos de usuário necessitavam de móveis que estivessem de acordo com as novas habitações e os novos modos de morar. Contudo, para a classe média existia o móvel moderno, que era oferecido em lojas especializadas, ou ainda aqueles feitos sob encomenda. Já a classe de baixo poder aquisitivo não tinha condições financeiras para fazer o mesmo.

Foi assim que surgiu o setor da indústria moveleira destinado a usuários de baixa renda. Para Folz (2003), entre os tantos problemas enfrentados nesse setor, a diminuição da qualidade dos móveis foi o único caminho adotado como alternativa de redução de custos: a economia de matéria-prima; a redução de detalhes, utilizando acessórios de plástico pouco resistentes; o baixo padrão de acabamento; e, principalmente, o pouco ou quase nada de investimento em design conferem ao móvel seriado extrema fragilidade, além de reduzir sua vida útil. ${ }^{33}$

Assim, ao ser inserida nas ideias progressistas advindas do processo de industrialização, a produção do móvel brasileiro incorporou o princípio do racionalismo como uma das formas de promover a produção industrial. Ao mesmo tempo em que houve esse pensamento racional e de estandardização em torno da fabricação em série,

\footnotetext{
${ }^{33}$ Apesar de ser um assunto bastante pertinente à produção do móvel no Brasil, o mobiliário seriado retilíneo não é foco desta pesquisa.
} 
ocorreu também uma busca por novas acepções que viabilizassem uma linguagem própria e específica da cultura brasileira.

Isso nos leva a crer que houve, em princípio, uma aceitação parcimoniosa de um olhar tautológico acerca dos fatores produtivos e das prerrogativas que condicionavam os objetos aos organogramas funcionais de melhor uso, no qual se deveria buscar a forma como expressão manifesta de sua função (de uso).

Entretanto, essa construção funcionalista na qual se recusa a metamorfose do objeto e sua temporalidade, o trabalho do tempo, e o trabalho da memória, foi se desfigurando à medida que as construções das linguagens foram sendo baseadas nas formas ligadas às tradições culturais e à exploração das possibilidades dos materiais, criando soluções de acordo com a realidade da tecnologia, do clima e do cotidiano do brasileiro.

Assim, essa condição, dada por meio de buscas às raízes e práticas culturais, bem como à experimentação de materiais nativos e corriqueiros junto ao povo, proporcionou ao design do móvel uma característica muito particular no cenário do design brasileiro.

Desde suas origens, com a incorporação dos móveis vindos de Portugal, até os que surgiram das propostas modernistas, a produção do mobiliário brasileiro sucessivamente apresentou processos em que a ressimbolização atuou de forma presente e permanente. Por mais que seguissem os preceitos funcionalistas, as propostas permitiam um maior grau de liberdade nos projetos, seja por meio do uso das referências da herança dos estilos coloniais, do tradicional, seja pelo uso das técnicas e materiais.

Nesses “objetos móveis", que se movimentam e que se movem, não existem formas extravagantes ou esvaziamento de conceito, mas "algo de outro" que os fazem reviver e lhes dá sentido. Um sentido visceral, um sentido comportamental ou um sentido reflexivo. Mas sempre, um sentido.

Este panorama essencialmente histórico encerra a análise realizada no período compreendido desde a colonização do Brasil até meados do século $\mathrm{XX}$, quando do início da produção seriada do móvel e do estabelecimento do movimento moderno no país. As considerações realizadas até o momento serão de fundamental importância para o entendimento do processo contemporâneo de transformações na moradia e na mobília. 


\subsection{Design de Mobília Contemporânea: conceitos formadores}

Independentemente das incidências estilísticas que porventura possam ser identificadas e aceitas pela teoria e história da arte e do design, o fato é que a história dos antecedentes do móvel contemporâneo reporta às suas origens e núcleos formadores.

Santos (1995, p. 155) afirma que durante as décadas de 1970 e 1980, a produção do móvel brasileiro era eclética e admitia várias vertentes: "O móvel de autor, assinado, com canais de venda e faixa de clientela próprios; o móvel de massa, que inundou o mercado para consumo popular [...]; o móvel reciclado, um certo revival da mobília do passado, em que cópias e obras verdadeiras coexistem em antiquários [...]”. Atualmente podemos incluir nessa lista a indústria do móvel planejado, dedicada às classes A e B.

O que nos interessa é trabalhar com a categoria "móvel de autor". Essa escolha se deu pelos seguintes motivos:

a) Mostra mais facilmente a assimilação dos conceitos de design no objeto móvel -, pois não possui tanta interferência e limitações dos processos industriais padrões da indústria moveleira;

b) Atesta uma assinatura que é representada pelo desenho a partir da concretização de uma ideia, e possibilita o entendimento da relação entre designer e obra mais claramente, ou seja, a relação autor-pessoa e autorcriador;

c) Não, necessariamente, segue os padrões estilísticos e mercadológicos de uma época;

d) Sugere maior diversidade de diálogos estéticos, simbólicos, de materiais e de produção;

e) Propõe "aberturas" mais facilmente identificáveis nas relações entre o indivíduo e objeto.

Entendemos que é a partir dessas considerações que se abre caminho para uma análise no que tange aos aspectos semissimbólicos e ao design emocional do objeto móvel.

Isso não significa que os demais atributos inerentes ao objeto utilitário serão desconsiderados, visto que já se pôde analisar e entender, mediante os conceitos de Norman (2008), a reciprocidade entre os aspectos viscerais, comportamentais e reflexivos dos objetos; mas significa, principalmente, a identificação dos valores mais 
expressivos da forma do objeto, utilizando-os como parâmetros para a sua análise e visualização na contemporaneidade.

Navegando no limiar entre a função utilitária do objeto - funções de uso e funções técnicas - e sua outra função, tão importante quanto, a função semissimbólica, é que se irá ao longo deste capítulo estabelecer as vertentes conceituais que fundamentarão o objetivo principal deste trabalho: analisar o móvel brasileiro por meio de conceitos do design emocional.

Em uma sequência preestabelecida, foram identificados seis aspectos/conceitos básicos, considerados essenciais, que servirão como nortes para o desenvolvimento do pensamento. Todos os conceitos serão exemplificados, ora por designers, ora por suas produções selecionadas por um processo qualitativo e empático que, ao nosso entender, representam tais categorias. A saber:

\subsubsection{Pioneiros e Contemporâneos}

Torna-se impossível fazer qualquer referência à produção do móvel contemporâneo sem uma alusão aos denominados pioneiros do design da mobília no Brasil. Por pioneiros entende-se a geração pré-década de 1970, demarcada por designers ícones do desenho moderno. Eles ficaram conhecidos nacional e internacionalmente, e trouxeram para a contemporaneidade uma significativa importância acerca da produção de sua obra.

A abordagem será feita a partir da concretização da cultura material brasileira e com base na autenticidade da ideia da busca pelas raízes matriciais. Esses designers fizeram uso da madeira, do couro, da chita e da fibra, enquanto materiais nativos; da rede e do banco caipira, enquanto códigos visuais simbólicos da cultura vernacular disseminados no imaginário coletivo brasileiro.

Contemporaneamente, continuaram utilizando esses modos projetuais, porém reorientaram seus projetos profissionais quando situados em um novo cenário social e econômico.

São eles: Lina Bo Bardi, Sergio Rodrigues e José Zanine Caldas. 


\section{a) Lina Bo Bardi (1914-1992)}

A atuação da arquiteta italiana radicada no Brasil em 1946 foi de extrema importância na abertura dos caminhos que a geração seguinte dos designers de móveis iria percorrer. Atualizada com a problemática contida na visão formalista bauhausiana e com a produção massificada do styling americano, Lina é uma entusiasta do processo de modernização do Brasil. Sua intervenção fundamentou-se na vontade de compreender o Brasil em uma dimensão político-cultural e traduzir em propostas de objetos a sua própria identidade moderna.

Seus trabalhos sempre apresentaram a característica de não se parecerem em nada com o que fosse encontrado no mercado. Era essa a intenção: não possuir tradição nem de desenho nem de processo industrial. As peças eram produzidas sempre tendo em conta a simplificação formal estrutural, extraindo as possibilidades que a madeira, o couro e os tecidos ofereciam como repertório formal brasileiro. Da madeira aproveitou a riqueza das cores e dos veios; do couro e dos tecidos como a chita aproveitou a leveza formal e o frescor necessários ao clima brasileiro. Foi no Studio Palma que se deu a introdução do uso da madeira compensada na produção do móvel, com vistas à redução de custos, amplamente utilizada nos anos seguintes por Zanine Caldas, como será visto logo a seguir.

Lina tende a conduzir seus trabalhos na busca de uma identidade cultural brasileira e no pré-artesanato popular. Para ela, fazer design era criar ancorada na realidade e na necessidade, porém a partir da sua própria realidade e da sua própria necessidade.

A mobília produzida por Lina expressava-se levando em conta a leveza imposta pelo clima e pelas possibilidades no trato com os materiais nativos. Com a adoção desses princípios, deu um salto renovador dentro do próprio movimento moderno.

A respeito da atividade permanente de Lina no setor cultural, Santos comenta

[...] com a belíssima lição de design popular que nos deu através da exposição “A Mão do Povo Brasileiro", organizada por ela em 1968, mostrou que é possível fugir à asfixia provocada pelo sistema, quando a precariedade de recursos funciona como elemento deflagrador da imaginação, fantasia e criatividade. (SANTOS, 1995, p. 98) 

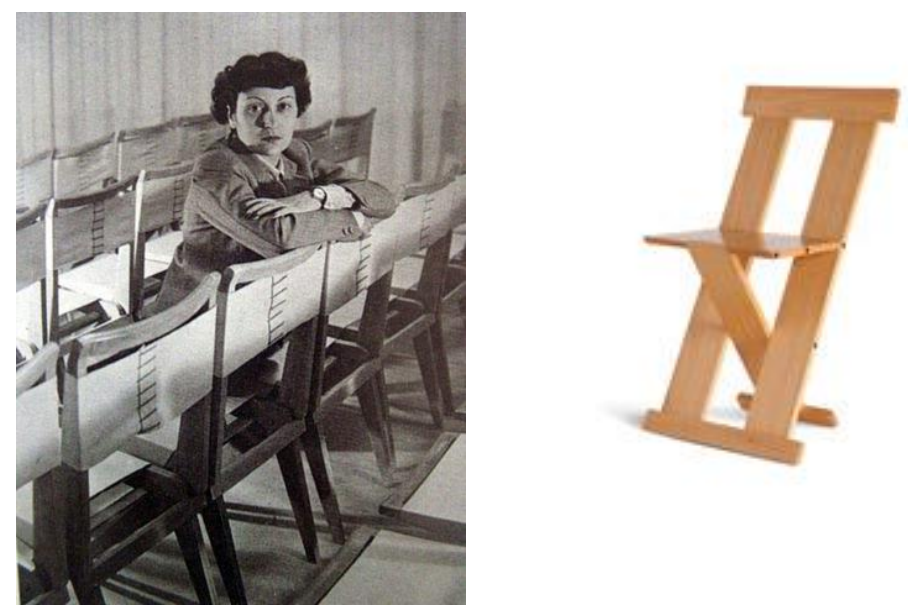

Figura 57 - Lina junto à cadeira dobrável projetada para o auditório do Sesc Pompeia, 1947, e cadeira Frei Egídio, 1987

\section{b) Sergio Rodrigues (1927-2014) - sintonia com a cultura brasileira}

Arquiteto de formação, Sergio Rodrigues é de fundamental importância tanto para o estabelecimento do movimento moderno no móvel, quanto para o reconhecimento da mobília contemporânea brasileira. É considerado um dos maiores representantes entre os criadores do legítimo móvel brasileiro,

[...] é o arquiteto, o "fazedor de móveis", o misto de artesão e designer que revolucionou o móvel brasileiro. Dos primeiros passos nos anos cinqüenta ao pleno reconhecimento atual da maturidade, é fora de dúvida que a mobília encontrou nele a sua mais alta expressão. Sergio Rodrigues criou objetos inesquecíveis, próximos da terra, da rede, do catre, do sentar do caipira, do singelo objeto indígena, do trabalho daqueles dois artesãos que fizeram a cruz. Em meio às vicissitudes deste momento da história brasileira, a obra de Sergio é um exercício apaixonado de redescoberta do Brasil. (SANTOS, 1992)

Sua maior contribuição está nos argumentos projetuais que utiliza durante o processo de criação e configuração de suas peças. Sua linguagem assinala códigos visuais característicos: de um lado, o seu próprio repertório, como autor-pessoa; de outro, a referência à materialidade mais simbólica da cultura popular e tradicional brasileira, como autor-criador. Assim é que manipula a matéria-prima - o couro, a madeira e a palhinha - e os símbolos de que lhe servem de inspiração - a rede, o sentar relaxado, a grossura e a robustez dos elementos.

Literalmente de vanguarda, Rodrigues antecipou para a década de 1950 questões que vieram aflorar apenas na década de 1960. O sentimento de nacionalismo se 
apresentaria efervescente no meio artístico e cultural brasileiro devido a acontecimentos políticos que marcaram época e estimularam o olhar para os problemas econômicos e sociais do país. A primeira peça de sucesso foi a cadeira Lúcio Costa, de 1956, que tinha como propósito um design mais compatível com os interiores da época.

Com muita vitalidade e exuberância, em maio de 1955 Sergio criou a Oca, para dar vazão a todo seu desejo de pesquisar e criar móveis modernos. Ele já havia bordejado por este tema, mas agora o espaço era próprio, o laboratório de idéias converteu-se em realidade, com requintes absolutamente inovadores para a época. Não se tratava simplesmente de desenvolver uma linha de móveis modernos, ele queria manifestar as coisas da terra pelo desenho e pelo uso de materiais. Tinha de ser um móvel genuinamente brasileiro. Aliás, estes valores já estavam fortemente arraigados em suas concepções. E não eram só as coisas do Brasil indígena, que Lúcio Costa tão bem caracterizou ao definir o novo empreendimento de Sergio Rodrigues. De fato, neste momento ele fez coexistir o Brasil brasileiro com o Brasil de Ipanema, cantado mais tarde, em 1962, por Tom Jobim e Vinícius de Moraes, na célebre "Garota de Ipanema". (SANTOS, 1992, p. 25)

Rodrigues fundou, em 1955, a Oca, loja de móveis onde tinha a intenção de comercializar sua produção. Após passar por experiências profissionais nas quais não teve oportunidade de desenvolver suas próprias propostas, Sergio criou um espaço onde pudesse trabalhar as suas expectativas relativas à produção do móvel moderno, que, segundo ele, deveria ser genuinamente brasileiro: do desenho ao material (SANTOS, 1995, p. 126).

Oca é casa indígena. A casa indígena é estruturada e pura. Nela os utensílios, o equipamento, os apetrechos e paramentos pessoais, tudo se articula e integra com apuro formal em função da vida. A simples escolha do nome define o sentido da obra realizada por Sergio Rodrigues e seu grupo. (COSTA, 1962 apud SANTOS, 1995, p. 126)

Nos anos 1960, Sergio criou a Meia-Pataca, uma empresa que vendia móveis de produção diferenciada da Oca. Se na Oca os móveis eram produzidos quase que artesanalmente, na Meia-Pataca a produção era em série e a um custo mais baixo.

Com a instauração da Oca veio a criação da Poltrona Mole, premiada na Bienal Concorso Internazionale Del Mobile em 1961, na Itália. Esse móvel se tornaria o mais significativo de todo o seu trabalho, cuja fundamental e mais conhecida característica 
seria a consagrada "estética da grossura", em contraponto aos delgados e elegantes péspalito importados dos Estados Unidos.

Acerca do texto do relatório da premiação:

[...] único modelo com características atuais, apesar da estrutura com tratamento convencional, não influenciado por modismos e absolutamente representativo da região de origem. (RODRIGUES, s.d. apud SANTOS, 1995, p. 128)

Apresenta em seus desenhos um traço intuitivo, diferente daqueles do estilo colonial que vigorava na época. Toma partido de seu conhecimento minucioso do processo construtivo da marcenaria e das características da madeira e os usa de forma lúdica e inesperada. Utiliza recortes incomuns para produzir encaixes, cria formas que, apesar de "grossas", proporcionam conforto e descontração.

Sergio Rodrigues foi convidado por Darcy Ribeiro para projetar parte do mobiliário da Universidade de Brasília, também na década de 1960. Ao todo foram cerca de 40 móveis entre mesas, estantes, cadeiras e sofazinhos. Lá projetou também a Oca I e Oca II, edificações que eram utilizadas como alojamento para professores e funcionários. Segundo Sergio, sua maior "aventura" na construção da UnB foi o projeto do mobiliário do Auditório Dois Candangos: entre a solicitação de Darcy Ribeiro e a inauguração do prédio, foram 15 dias corridos. Para o auditório foram produzidas 249 cadeiras e uma mesa principal (AVIANI; COSTA JR., 2013).
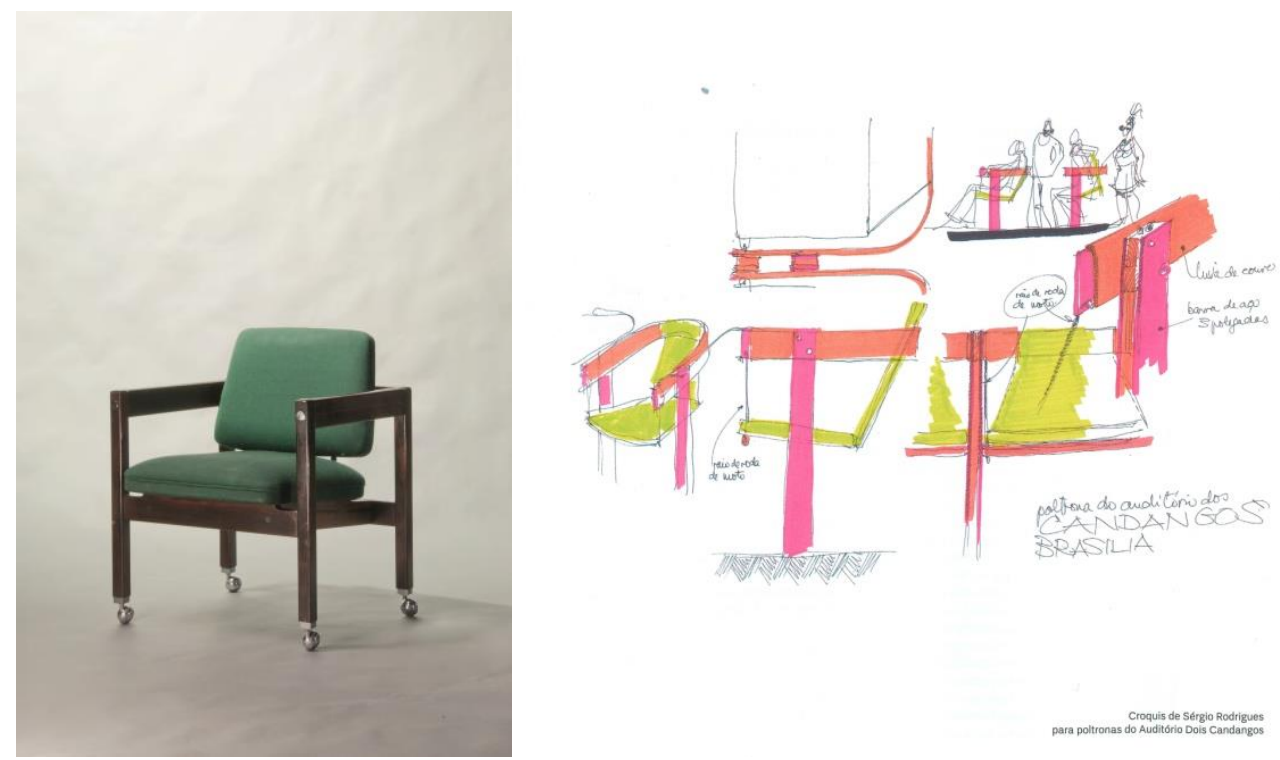

Figura 58 - Poltrona Kiko para o Salão de Atos da Reitoria; croquis para a poltrona do Auditório Dois Candangos, Universidade de Brasília, década de 1960 

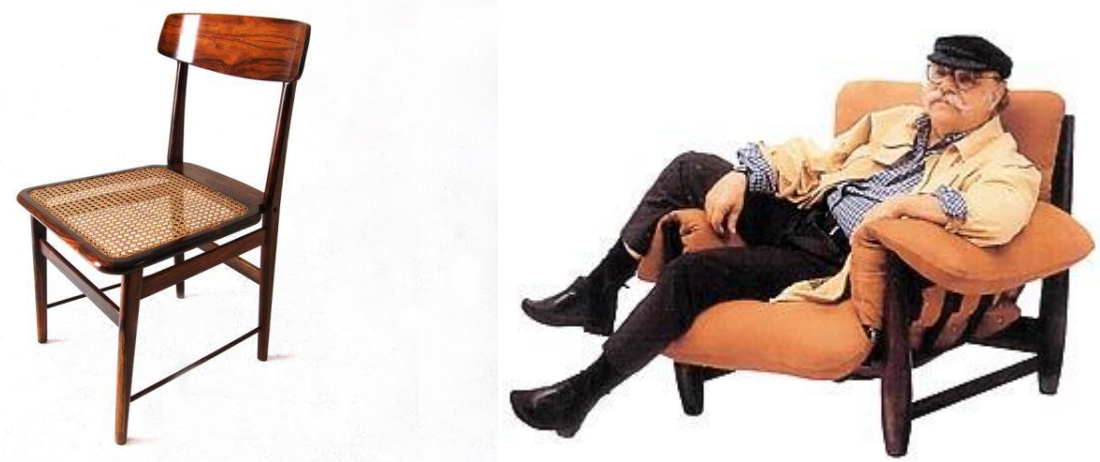

Figura 59 - Cadeira Lúcio Costa, 1956, e Poltrona Mole, 1957
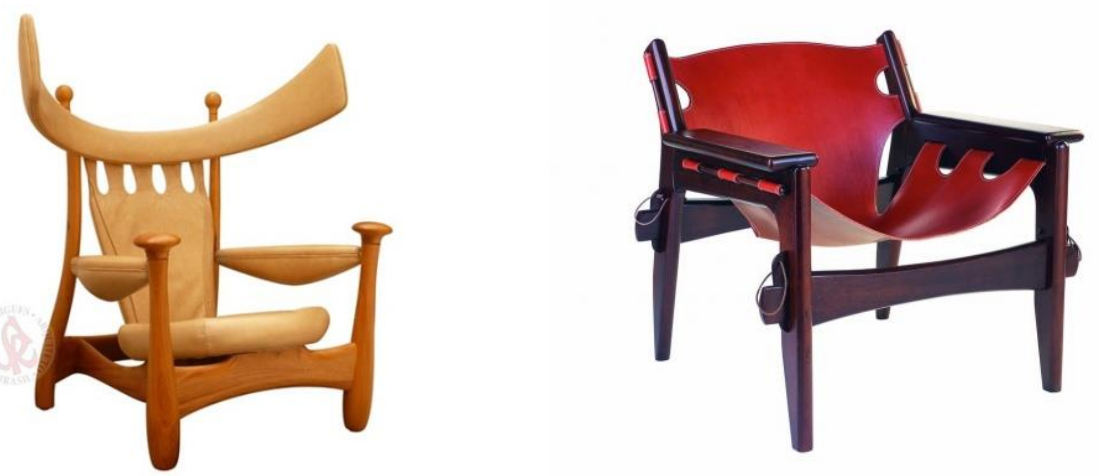

Figura 60 - Cadeira chifruda, 1962, e Poltrona Kilin, 1973

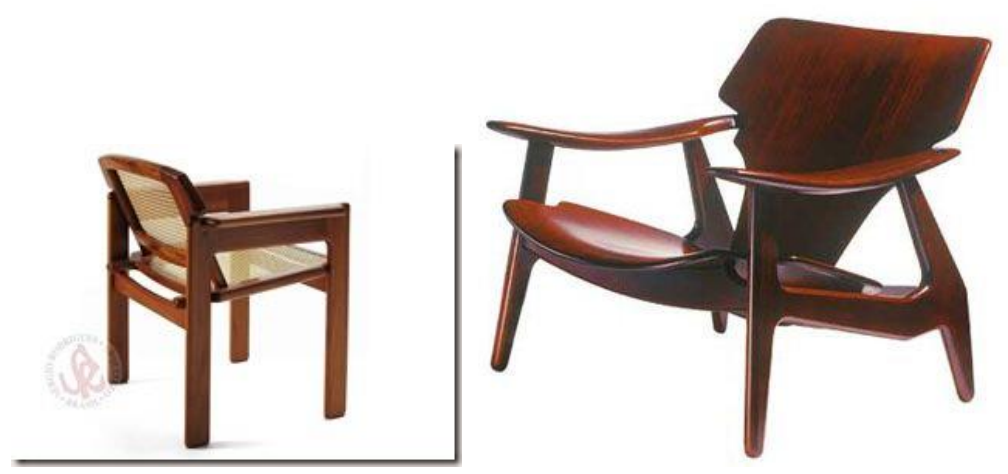

Figura 61 - Poltrona Julia, 1980, e poltrona Diz, 2001

c) José Zanine Caldas (1919 - 2001) - o espírito criador

Vivo de formas e cores. O primeiro momento é do espaço e do volume. Em seguida vem a textura. Depois começo a perceber e 
analisar a cor. Aí é que pergunto: e agora? Vai servir para quê? A primeira coisa para mim é a beleza. (ZANINE apud LEON, 1989, p. 140)

A obra de Zanine é o reflexo da versatilidade do espírito criador, representado tanto na produção dos móveis em série quanto ao configurar peças únicas artesanais, qualificadas como móveis “denúncia”. É conhecido pelos teóricos da área como o "mago da madeira", pois experimentou infinitas possibilidades de manipulá-la como matéria-prima.

Santos (1995) relata a trajetória do designer/artista desde a fundação da fábrica de Móveis Z, em 1950, onde aplicou todo o conhecimento sobre a madeira compensada que havia desenvolvido primeiro como maquetista e depois como estudioso, com o apoio do IPT - Instituto de Pesquisas Tecnológicas do Estado de São Paulo. Santos define esta como a primeira fase. A segunda fase é aquela referente às experimentações do valor escultórico da madeira bruta, sempre em grandes dimensões e utilizando os recursos naturais.

Com a possibilidade tecnológica e seu profundo conhecimento sobre o compensado, a Móveis $\mathrm{Z}$ atingia principalmente a classe média brasileira. Mantinha uma produção baseada no conceito de racionalização, tanto da matéria-prima e do fluxo produtivo quanto da mão de obra especializada.

A concepção formal do mobiliário foi se constituindo de maneira gradual e particular. Usando chapas de compensado recortadas em linhas curvas, de aparência pouco convencional e muito marcante, construiu o maior código visual da sua marca: os recortes em formato "Z", somados às tachinhas utilizadas para fixar o tecido de acabamento tanto do assento quanto do encosto das peças.

$\mathrm{Na}$ segunda fase, Zanine rompe totalmente com as experiências industriais e se dedica a desenvolver peças a partir de um discurso de aproveitamento dos recursos naturais. Em uma primeira abordagem, as peças produzidas são caracterizadas como "móveis denúncia", ou esculturas utilitárias brutas, pois "vão mostrar aos homens do futuro as provas de existência dessas madeiras, provavelmente extintas, se a raça humana continuar do jeito que está" (LEON, 1989, p. 138).

$\mathrm{Na}$ segunda abordagem, Zanine utiliza como matéria-prima os restos de madeiras encontradas nos desmatamentos e queimadas das florestas. Os objetos ou peças originadas desses refugos são portadores de um desenho derivado de suas 
próprias formas naturais; pela habilidade de escultor, são retiradas as formas e funções que cada refugo pode proporcionar, transformando-se em mesas, cadeiras e luminárias.

O conjunto da sua obra traz para esta análise uma contribuição no sentido de que, ora pelo pioneirismo da produção em série, ora agregando um discurso "ecológico" e de protesto na criação, tão atual nos dias de hoje, Zanine sempre deu vazão à sua capacidade expressiva e criativa.

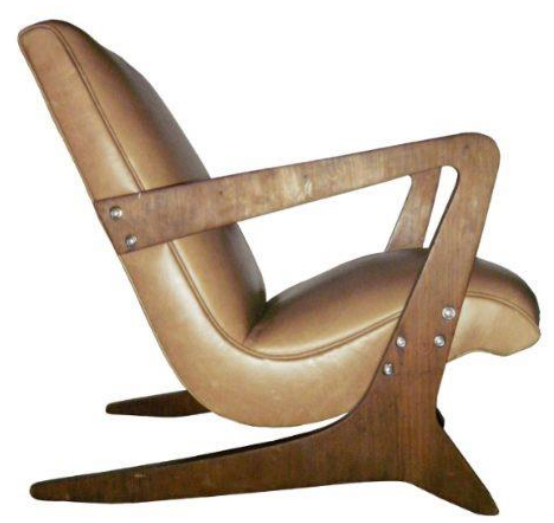

Figura 62 - Poltrona Móveis Z - recorte curvo na madeira compensada, década de 1950

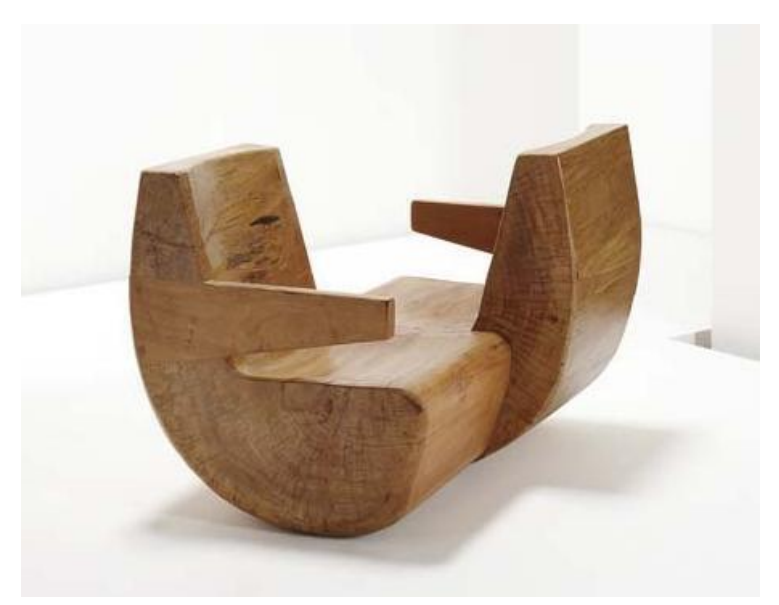

Figura 63 - Namoradeira - Zanine Caldas, década de 1980 


\subsubsection{Absorvendo (ou dissolvendo) o modernismo}

Como já colocado no capítulo anterior, condizente com as transformações ocorridas nos espaços internos das residências e com as novas formas de moradia, a mobília contemporânea começou a adquirir características próprias em sua tipologia.

A casa, além agregar as funções tradicionais de repousar e abrigar, retoma a função de local de trabalho, já exercida no medievo das manufaturas. O lazer doméstico conquistado a partir da industrialização também é alterado em razão dos novos equipamentos como home theater e equipamentos eletrônicos. Assim, a casa contemporânea assume, ao mesmo tempo, a função de abrigo, local de trabalho e local de lazer.

A mobília teve de se ajustar a essas prerrogativas, com características como desapropriação das referências em torno da utilidade, redução dimensional e assimilação do conceito de multifuncionalidade, isto é, acréscimo de funções de uso. Nessa fase também é interessante destacar a retomada do conceito de móvel como "móbil, mover", pois ele adquire dentro da casa maior "mobilidade" e "flexibilidade".

Para tanto, atravessa a estrutura tradicional de móveis para sala, móveis para cozinha e móveis para escritório, para sofá-cama, armário embutido multifuncional, mesas escamoteáveis, entre outros.

A função utilitária recupera, porém, o lugar histórico da mobília. Assim, namoradeiras, preguiceiras, cristaleiras, marquesas e buffets - peças de mobiliário de nossa herança colonial - ressurgem na contemporaneidade com funções reinventadas, assumindo novos desenhos, formas e usos, aludindo para uma retomada histórica em uma nova "veste" projetual. Acerca disso, Baudrillard disserta:

Esta mesa neutra, leve, escamoteável, esta cama sem pés, sem caixilho, sem dossel, que é como que o zero grau da cama, todos esses objetos de linhas "puras" que não tem nem mesmo a aparência de que são, ficam reduzidos à sua nudez e como que definitivamente secularizados: aquilo que neles se liberta, e que, libertando-se, libertou algo no homem (ou que o homem, libertando-se, neles libertou) é a sua função. Esta não é mais obscurecida pela teatralidade moral dos velhos móveis, desembaraçou-se do rito, da etiqueta, de toda uma ideologia que faziam do ambiente o espelho opaco de uma estrutura humana reificada. (BAUDRILLARD, 1993, p. 24) 
O desenho da mobília revisa seu papel utilitário e estático dentro das moradias; e aquele que cria, portador do repertório social e cultural de sua sociedade, exprime, baseado em uma visão particular e geral, o produto resultante dessa situação.

Neste item serão mostradas as obras e autor que exemplificam a diversidade de soluções projetuais e destacam a constituição e a reinvenção da função da mobília dentro do espaço das moradias desse período.

a) Pedro Useche (1956 -)

O arquiteto venezuelano Pedro Useche chegou ao Brasil em 1984, e logo se integrou ao mercado profissional. É considerado um arquiteto/designer que possui uma linguagem bastante peculiar. A respeito de sua arquitetura, Livia Pedreira comenta:

Com um estilo particular, o venezuelano Pedro Useche filtra em sua leitura várias referências clássicas, medievais, góticas e modernas. Implantada num terreno de esquina, no Morumbi, a casa provoca um impacto visual, pois lembra uma fortaleza ou as construções medievais. Paradoxalmente, no interior a casa se abre em espaços amplos, garantindo um perfeito domínio dos ambientes. Os espaços internos, detalhados à exaustão, traduzem uma simplicidade de refinada elegância. (PEDREIRA, 1991, p. 28)

É assim que Useche desenvolve suas peças, ora fazendo uso de referências do passado, ora usando a expressão de formas sem excesso. Para ele, o início do desenvolvimento de uma peça consiste no entendimento de uma função, da identificação de uma necessidade de uso na rotina diária da vida das pessoas. Nesse sentido, além de questões estéticas e simbólicas, o móvel deve trazer consigo novas propostas de uso e proporcionar o acúmulo de funções, ou seja, proporcionar multifuncionalidade. Esta é uma condição bastante peculiar, semelhante à época em que os móveis do medievo assumiam também múltiplas funções.

Por outro lado, seu trabalho apresenta uma característica que se apoia nos conceitos do pós-modernismo ${ }^{34}$ pela diversidade de materiais experimentados, como ferro, madeira, pedra, vidro, couro, borracha, entre outros.

Em depoimentos concedidos em várias entrevistas, Useche esclarece que a condição básica de seu trabalho é fundamentada na "utilidade funcional" de seus

\footnotetext{
${ }^{34}$ Aqui entendido como um movimento que propunha maior liberdade de expressão, tanto nas formas quanto no uso dos materiais. Também como um revival dos estilos antigos em contraposição às normas rígidas da boa forma do modernismo.
} 
objetos, aquela que diz que a função primeira da cadeira é ser um suporte para o corpo; e não na condição estética. Contudo, ao fazer uso dessa prerrogativa, também diz que sente a necessidade de criar algo diferente, de ir um pouco além. Entendemos que esse “ir além" remete à manipulação de outra função, a semissimbólica.

Sobre seus móveis, Lívia Pedreira afirma:

Usando cobre, ferro e madeira (principalmente o mogno), Pedro Useche desenha objetos de linha puras, sem qualquer excesso. Essa pureza, no entanto, vem sempre acompanhada por uma certa irreverência e uma ousadia sutil. (PEREIRA, 1991, p. 28)

É característica do autor, além de pensar nas diversas "funcionalidades" que um móvel pode ter, propor um adensamento de efeito lúdico e "bem-humorado", por vezes chegando a brincar com o imaginário dos usuários, como ilustrado nos produtos da figura 64 .
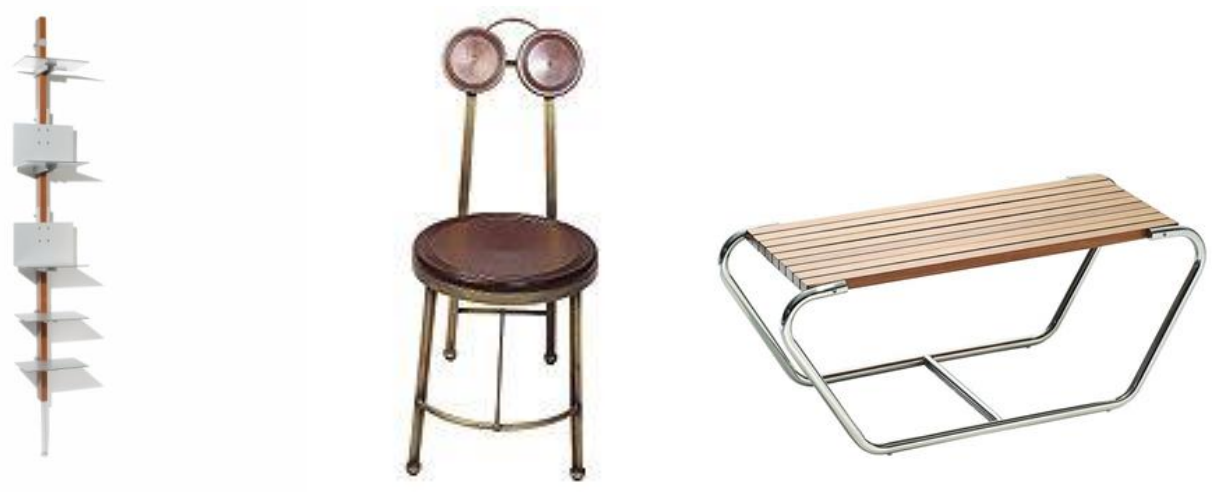

Figura 64 - Revisteiro Eixo 7 (1998), cadeira Mulher (1989) e mesa lateral Inex (s.d.)

\subsubsection{A brasilidade no móvel}

As singularidades, quando genuínas, alcançam valor universal.

(Marcelo Carvalho Ferraz)

Por volta das décadas de 1950 e 1960, como já visto, houve um movimento cultural que tinha como princípio a legitimação da identidade cultural da nação brasileira. Na mobília, nomes como Joaquim Tenreiro, Lina Bo Bardi, Michel Arnoult e Sergio Rodrigues são alguns dos protagonistas e referências quando se trata da utilização de elementos simbólicos da cultura brasileira tradicional e popular. 
Ao longo do texto fomos levantando certas situações que nos levaram a algumas conclusões. Uma delas diz respeito aos principais elementos e referências para esse processo de configuração, que podem ser classificados em: 1) os materiais nativos diversidade de espécies de madeira, as fibras, o couro, os tecidos de algodão; 2) os verdadeiros códigos visuais da cultura popular - o banco caipira, a rede, as técnicas do artesanato; 3) as técnicas de produção - o fazer artesanal, tipos de encaixe, malhetes e marchetarias herdados dos móveis coloniais; 4) o fazer artesanal - a interferência própria do ser humano e sua manualidade.

Essas características foram se sedimentando no imaginário coletivo como legitimadoras das origens culturais simbólicas da brasilidade.

Apesar de a contemporaneidade apresentar aspectos sociais, políticos e culturais extremamente diferentes daqueles do período moderno - como o processo de globalização e as questões multiculturais -, as imagens identificadoras da cultura material brasileira popular e tradicional são símbolos e ainda continuam a ser fonte de referência para diversos designers atuais.

Esta análise mostra-se sempre atenta ao processo dialético entre o universal e o nacional, o geral e o particular, em maior ou menor proporção.

\section{a) Marcenaria Baraúna - a cultura popular brasileira como matriz (1986)}

Fundada em 1986 em São Paulo, a Marcenaria Baraúna é conhecida por sugerir uma linguagem contemporânea singular e com referência aos códigos da cultura popular brasileira.

A primeira grande premissa do trabalho apresentado pela Baraúna é o "olhar atento às coisas da terra" ${ }^{35}$, por influência da postura de Lina Bo Bardi e de sua abordagem quanto às questões da cultura vernacular nordestina. Ou seja, trazer para a vida contemporânea um conceito de trabalho que reflete esse "olhar" sobre as coisas, os objetos, a cultura popular.

A segunda é pautada pela experimentação com as madeiras brasileiras. Com uma consciência tanto de preservação quanto de experimentação com novas espécies, o trabalho reflete como são exploradas as possibilidades técnicas, estéticas e produtivas da matéria-prima. Isso também é proposto com relação à utilização da madeira em seu estado natural, sem uso de químicas que possam esconder as características físicas do

\footnotetext{
${ }^{35}$ Disponível em:<http://www.barauna.com.br/>.
} 
material. É comum encontrar peças produzidas em angelim-pedra, cabreúva e cumaru, espécies consideradas madeiras alternativas.

A terceira premissa da Baraúna diz respeito à percepção entre objeto e espaço, conforme proposta pelo modernismo, que em essência não deve esconder nenhum tipo de encaixe ou estrutura.

Associações ao imaginário coletivo como referências ao "morar brasileiro", "bem-estar" e "acomodação" são colocadas sem artifícios, proporcionando uma relação de empatia entre objeto e sujeito.

Os valores apresentados pela Baraúna são tão explícitos nos objetos, que ao serem observados provocam uma reação imediata de identificação ou rejeição pelo observador. São objetos que realmente têm algo a dizer e que são "alcançados" pela apreensão perceptiva - são objetos extremamente emocionais. São móveis honestos ao que se propõem.

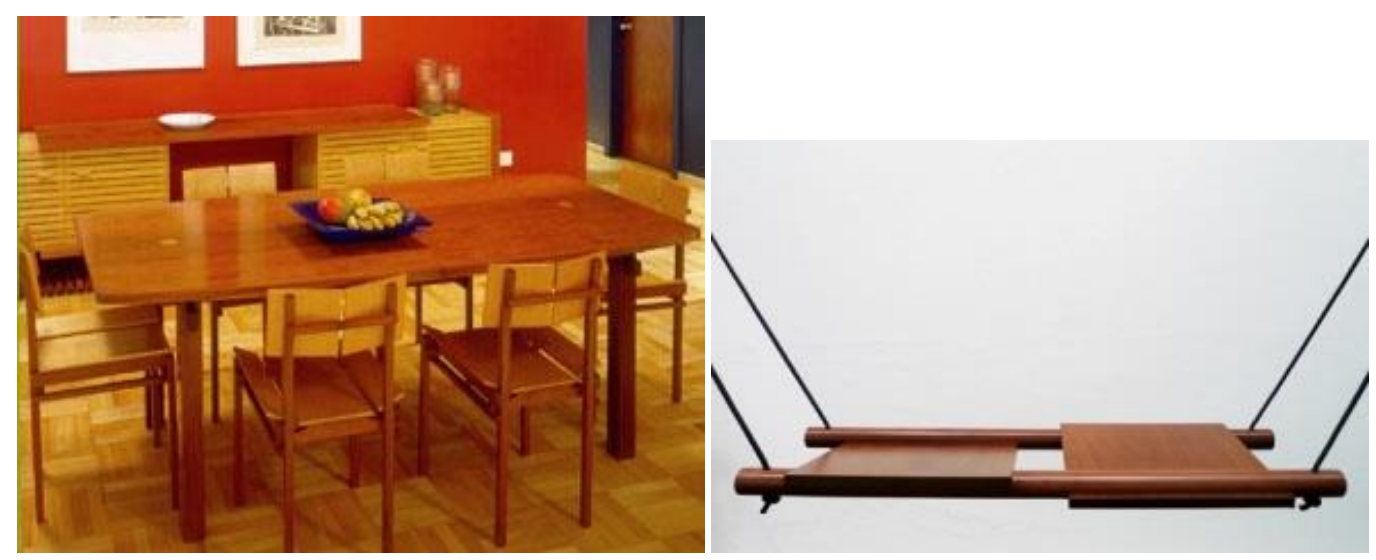

Figura 65 - Conjunto de mesa e cadeira, e balanço Amor Perfeito (instalação para o MCB, 2014)

\section{b) Maurício Azeredo (1948 - ) - brasilidade}

Apesar de não se dedicar atualmente à produção de seus móveis, Maurício Azeredo ainda é considerado pela crítica como símbolo de uma linguagem sintonizada com o sentimento de brasilidade na cultura e um dos designers mais representativos da contemporaneidade. Azeredo dialoga com a tradição e a contemporaneidade.

Observa-se em seus trabalhos o resgate e a valorização de elementos característicos da cultura popular. Enquanto muitos designers se dedicam ao projeto de cadeiras, Azeredo aposta nos bancos como referências às origens caboclas e indígenas.

Sobre sua escolha, comenta: 
Antes mesmo que aqui chegassem os colonizadores, o banco já era do universo material dos habitantes do nosso território. Ora representações zoomorfas esculpidas em uma peça só de madeira, a exemplo dos feitos pelos Kuikuro, os Uapé e os Karajá, ora nas talhas não figurativas como os do Assurini, dos Waiwai e dos Tukano, os bancos compunham, juntamente com a rede, o mobiliário indígena. Também o português do século XVI pouco mais possuía do que isso. A casa portuguesa, à exceção dos espaços palacianos, raramente abrigava mobiliário diversificado. Além das alfaias, herança árabe, alguns catres, baús, cadeiras rasas e, principalmente, bancos coletivos constituíam sua mobília. Assim como no início da colonização, ainda hoje, no mais das vezes em lugares afastados dos grandes centros urbanos, a casa brasileira permanece despojada. Sempre, entretanto, o banco anônimo e coletivo. Tosco ou elaborado, à cozinha, à sala, junto à mesa ou no avarandado, é peça fundamental no mobiliário vernáculo brasileiro. Por esta razão buscamos revitalizá-lo e volvê-lo objeto de desenho. (AZEREDO apud CAVALCANTI, 2001, p. 177)

A obra de Azeredo não só se faz por uma reflexão sobre os hábitos e costumes mais característicos de nosso povo, mas também pelo uso da madeira, sua matéria-prima por excelência. É nela que se funda o outro argumento de seu trabalho: a utilização de nossa matéria-prima natural.

A diferenciação está na aplicação de diversos tipos e qualidades de madeiras, apresentando pela primeira vez ao público brasileiro peças com diversas madeiras associadas, que juntas conferem uma dimensão plástica e artística jamais vista no design do móvel nacional.

A técnica utilizada por Azeredo também se baseia naquelas artesanais, contudo ele resgata, reinventa e brinca com as técnicas tradicionais de construção, como o malhete e o alfarje, aplicando uma diversidade de texturas e cores de madeiras, da mesma forma em que restaura antigas técnicas de marcenaria e congrega a experiência dos antigos artesãos. $\mathrm{O}$ apuro técnico que alia ao trabalho artesanal evidencia encaixes precisos e perfeitos, recuperando os trabalhos tradicionais em madeira em que as junções dispensavam o uso de parafuso ou prego.

Em seu trabalho fica evidente que o processo criativo está subordinado às questões funcionais, estéticas e simbólicas. Pois, se por um lado, atende aos requisitos funcionais, por outro, trata da dimensão simbólica como resgate às origens, à tradição pela expressão artística, plástica e emocional de suas peças. "Temos buscado a convivência e interação entre as dimensões funcional e emocional do objeto, como 
produto impregnado por arte" (AZEREDO apud CAVALCANTI, 2001, p. 177, grifo nosso).

Por tais razões [racionais] e emoções desenvolvo meu trabalho da forma que se apresenta. De um lado, o anseio pelo domínio técnico e o cuidado com a precisão; por outro, tendo como suporte a estrutura e o produto industrial - a individualização do desenho, a escolha da madeira, das cores e dos tons - veio a veio -, a procura da emoção a cada peça e a renovação como meio, como caminho para o prazer. (AZEREDO apud CAVALCANTI, 2001, p. 182, grifo nosso)
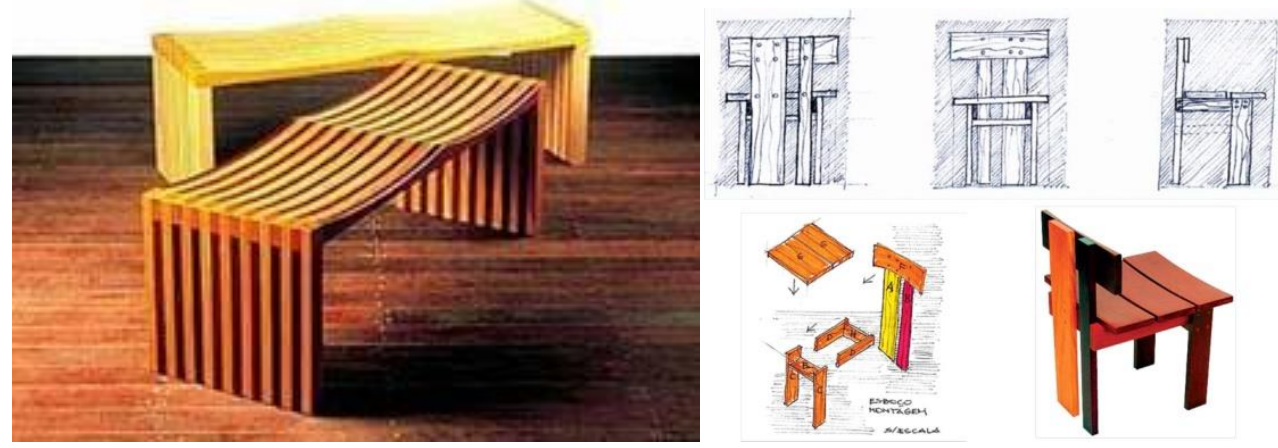

Figura 66 - Banco Ressaquinha, muirapiranga e pau-ouro (1988); e banco da série Do Avesso

\subsubsection{Limite entre arte e design}

Aqui o conceito de utilidade não está relacionado à dimensão física ou à usabilidade, mas à sua dimensão simbólica e emocional. A maioria dos objetos ditos "utilitários" e batizados de "artísticos" está, na verdade, tentando travar um diálogo com o observador.

A contemporaneidade leva a um tipo de solução projetual dos objetos utilitários como aqueles mensageiros de características que, de imediato, não revelam o seu valor de uso, embaraçando o observador com uma ambiguidade que pretende aproximar a vida cotidiana da arte.

O mobiliário contemporâneo é um dos representantes da classe dos objetos utilitários que mais passa por experimentações dessa natureza: o limite entre utilidade e dimensão cultural.

Vários autores comentam sobre o tênue limite entre contemplação e utilização dos objetos. Os chamados "signos utilitários e não funcionais" (PIGNATARI, 1995, p. 
101) são exemplo disso. Uma confirmação célebre dessa denominação citada por Pignatari é a Cadeira Red and Blue, de Gerrit Rietveld, de 1918.

Sem o apego ao emprego da função prática ou de uso como premissa na concepção projetual, essa categoria sinaliza para uma experimentação da manipulação das qualidades semânticas e simbólicas do móvel, induzindo o indivíduo a uma condição de relação emocional com o objeto a partir da provocação, que pode levá-lo tanto às emoções de encantamento quanto de repugnância.

O principal objetivo desse grupo é fazer uma análise usando os pressupostos como a codificação da vida cotidiana, o uso de diferentes materiais e o conflito das referências em torno da função prática, contrapondo-a a semissimbólica.

a) Irmãos Campana, Humberto Campana (1953 - ) e Fernando Campana (1961 -) - gesto e poesia

Nascidos na cidade de Brotas, no estado de São Paulo, Fernando tem formação em arquitetura, e Humberto, em direito. Em uma linguagem na qual a narrativa vai sendo construída em face do confronto de ideias e que permite o surgimento de relações surpreendentes e inesperadas entre elementos aparentemente distintos, os Irmãos Campana desenvolvem móveis e objetos com o uso de materiais inesperados. Trabalham com vários tipos de materiais que não são tradicionalmente utilizados no mobiliário. Corda, bichos de pelúcias, sarrafos de caixas de madeira de feira, bonecas de pano, plástico bolha, mangueiras de PVC, formas de pizza: essas são sua matéria-prima.

Lançando mão de uma linguagem com ironia e humor em muitos dos seus projetos, estes designers chegam próximos ao nonsense. Seus trabalhos recorrem a "procedimentos de descontextualização familiares para nós e que deslocam o sentido de um campo a outro, brincando com nosso saber e nossas expectativas" (JOLY, 1996, p. 63). É nesse aparente descompasso ou desvio, nesse choque do tempo passado e do tempo presente, no choque das funções e dos valores que se instaura o trabalho dos Irmãos Campana.

Um caminho importante para uma reflexão acerca do seu trabalho dá-se quando, ao questionarem os princípios funcionalistas do design e a busca de uma linguagem universal até então em voga entre aqueles que faziam e discutiam o design, eles se apropriam de referências outras como a não aceitação em optar pelos materiais tradicionais, o uso deslocado destes e a utilização de uma produção final não industrial. 
Na concepção dos Campana, uma cadeira feita de sarrafos de madeira provenientes de caixas encontradas em feira não deve ser entendida como menos digna do que aquelas fabricadas industrialmente em aço inoxidável, por exemplo. Quando retiram das ruas matéria-prima ou quando buscam em lojas populares materiais industriais simples, como complementos para a construção (fios, cordas, ralos plásticos), os designers contestam a importância atribuída ao material usado comumente, colocando-o em uma esfera de valor diferente e inversa da então utilizada e difundida.

Com essa inversão, rebatem as premissas que constituem os instrumentos de validação tão comumente disseminados do design, fazendo uma crítica aos modelos que concebem o produto baseado na função prática ou de uso. Na obra dos Campana, o que é particular e símbolo de inventividade advém daquilo que é comum e sem valor tradicional. $\mathrm{O}$ uso de uma linguagem que permeia o design e a arte é também um modo que utilizam para discutir a tênue linha que separa e define as duas atividades. É o gesto dos autores que, ao colocarem suas assinaturas, faz com que produtos que não possuam um valor em si o adquiram, em função do juízo de um sujeito e da validação conferida a eles pela definição de uma "autoria".

Os Irmãos Campana evidenciam uma escolha por uma linguagem de trabalho diferenciada, na qual se apropriam de propostas estéticas anacrônicas e, explorando seu potencial crítico, atribuem um novo estatuto como tendência do design atual. Utilizam o design como um espaço crítico ao empregarem referências com propostas contestatórias e deslocamento conceitual, provocando novos olhares e atitudes, em um processo semissimbólico, emocional, intersubjetivo e empático. Os temas em desuso, a apropriação da sujeição cotidiana, a referência ao gosto popular, o caráter lúdico e irônico conflitante ao utilitarismo são alguns dos aspectos explorados.

Em um processo emocional e semissimbólico, ao utilizarem diferentes materiais em combinações e usos imprevistos, eles não só rearticulam as relações do design e o meio, como compartilham com o sujeito esta postura, fazendo com que o objeto, na figura de um personagem, o conduza através de suas experiências. Ao sugestionarem a imaginação, destacam a importância da percepção e da sensibilidade do indivíduo, e rearticulam a ideia do indivíduo subjetivo e suas experiências instituídas cultural e historicamente.

Os Campana mantêm um diálogo entre os fundamentos do design e os da arte, e utilizam uma linguagem que se institui nos limites do objeto estético com o objeto utilitário, estimulando a discussão sobre os critérios de funcionalidade, utilidade, 
estética e símbolo como elementos limítrofes e sobrepostos entre as duas áreas. Os Irmãos Campana buscam na dimensão emocional e existencial da arte o característico para suas criações.
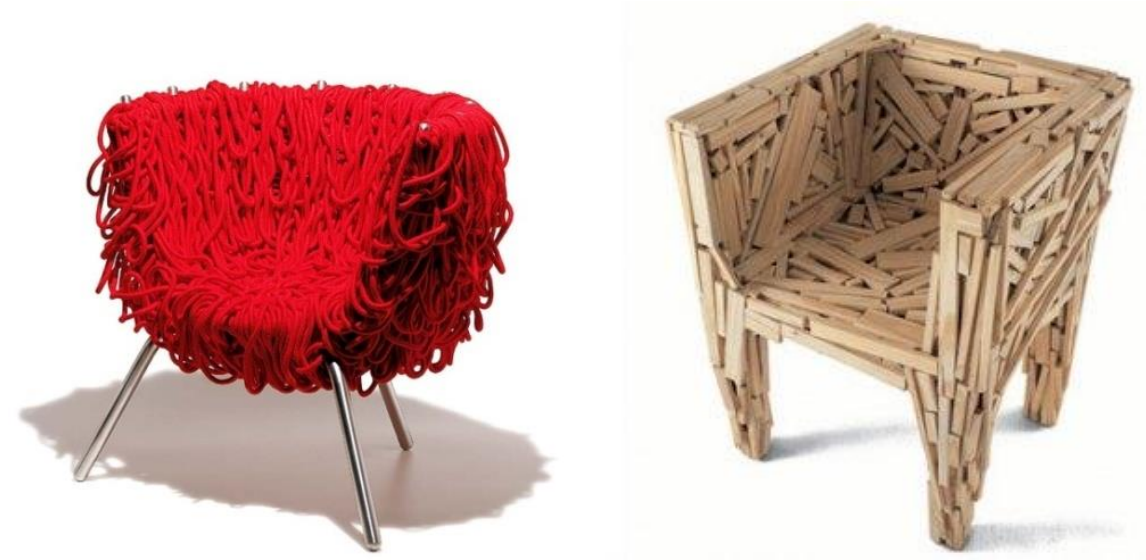

Figura 67 - Cadeira Vermelha, 1993, e Cadeira Favela, 1991

\section{b) Sérgio Matos (1979 - ) - poesia e regionalismo}

Mato-grossense radicado na Paraíba, Sérgio Matos é hoje uma das grandes promessas do design contemporâneo brasileiro. Trabalha no universo do regionalismo e da poesia. Suas peças são sempre inspiradas em formas e objetos encontrados no cotidiano regional de sua terra natal, ou do interior e litoral nordestino.

Trabalha com cores fortes e alegres. Das feiras com artesanato típico de cada cidade, dos materiais regionais, e das comunidades de artesãs vem sua inspiração para criar as peças. Utiliza desde fibras naturais oriundas do algodão colorido paraibano até fios de nylon, sempre em um processo artesanal: "Como na região não temos indústria de alta tecnologia, procuro utilizar o que tenho ao meu redor. Hoje as empresas me procuram para desenvolver produtos com os fios coloridos da Paraíba”, diz Matos. ${ }^{36}$

O designer trabalha entre o limiar da junção criativa e funcional. Para ele, as referências de suas andanças e de um olhar apurado para as coisas da vida brasileira tornam-se objeto. Os frutos, as flores, os cactos coroa-de-frade - flora típica nordestina -, os cestos amontoados nas feiras livres, as manifestações folclóricas e as festas populares ganham formas que são compostas por memórias e tornam-se carregadas de sentimentos, poesia e sensações.

\footnotetext{
${ }^{36}$ Consultar:<http://www.pernambucoconstrutura.com.br/fazendosala/?tag=sergio-j-matos>.
} 
Por sua gama de trabalhos e sua forte influência pelas coisas da terra e pelo regionalismo, poderíamos incluí-lo também na categoria 3.3.3 - "Brasilidade no móvel". Pensamos, contudo, que a categoria "Limite entre arte e design" se configura mais adequada, pois o designer se articula e navega com formas mais livres e mais poéticas sobre a cultura brasileira.

A produção de Sérgio Matos nos leva a uma relação com seus objetos por meio da subjetividade, da emotividade, despertando nossas memórias individuais e coletivas a partir do uso de referências extraídas do patrimônio material e imaterial brasileiro.

Suas peças traduzem uma poética e evocam uma relação afetiva pela cultura nordestina, evocando memória e tradição.

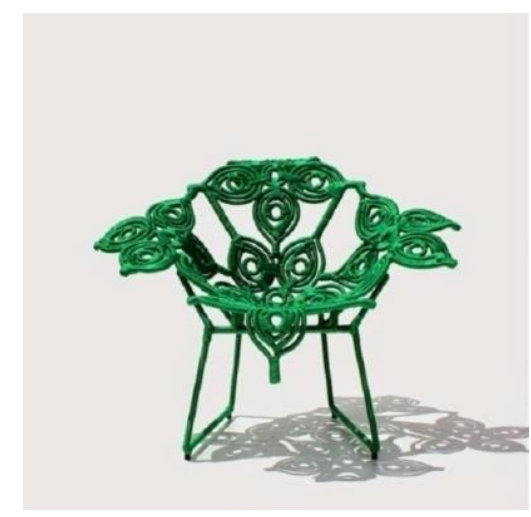

Figura 68 - Cadeira Chita, inspirada nos desenhos das flores encontradas nos tecidos de chita. As flores são confeccionadas em estrutura de metal soldadas uma a uma e depois cobertas com fios coloridos.

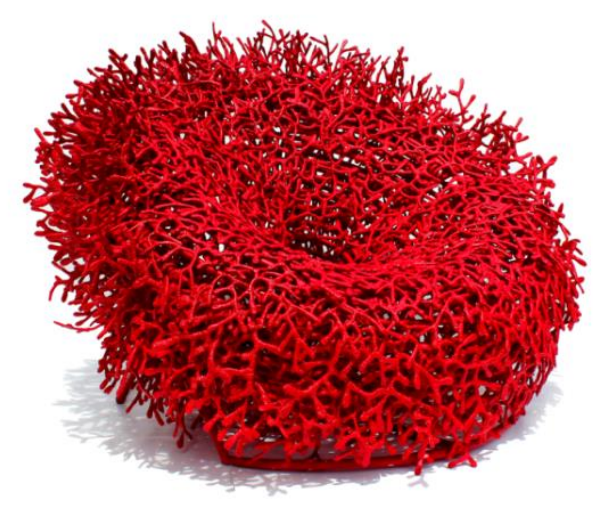

Figura 69 - Poltrona Acaú, inspirada nos corais "Chifre de Alce". Os corais são confeccionados em pequenas peças de metal cobertas uma a uma com fio, unidas a uma base também de metal que forma a poltrona. Por fim, é aplicada uma tinta (vermelha) sobre toda a superfície, dando a sensação de 1.2.1 ser uma peça só. 


\subsubsection{Do artesanato à industrialização}

Pode-se dizer que o processo de industrialização geral no Brasil ocorreu de maneira acidentada, com dificuldade para se modernizar tecnicamente, refém do vício da cópia e pouco adequada às condições brasileiras. No setor moveleiro não foi diferente. Daí muitos autores defenderem a ideia de que houve uma divisão entre a produção industrial e o design de mobília.

Se, por um lado, a indústria era portadora de um desenho repetitivo, pouco original e baseado na cópia (fosse ela de modelos estrangeiros ou não), por outro, as experimentações do design eram produzidas em processo artesanal e de pequena escala. Esse modelo se perpetua até os dias de hoje como uma característica do setor moveleiro.

Esses dois caminhos ocorrem paralelamente. A formação da indústria moveleira foi dada a partir de imigrantes que abriram pequenas marcenarias, baseadas na produção e técnica artesanal, e que depois resultaram em indústrias. Já por outro caminho, os pioneiros do desenho do móvel moderno que também traziam a prática e a tradição artesanal em suas bagagens, embora com propostas inovadoras tanto em termos de produção quanto, e principalmente, em termos formais e de concepção, não encontravam espaço para a produção industrial.

Persistem até hoje duas situações decorrentes desse processo: a primeira, a existência de uma indústria de reprodução em larga escala, com pouco desenvolvimento no tocante ao design; a segunda, a produção manufatureira desenvolvida em pequena escala, com fazeres artesanais, desenvolvimento e experimentações necessários aos projetos de design, destoando da premissa fundadora do conceito de design industrial: produção industrial em série.

É certo que, em determinados casos, a união entre indústria moveleira de massa e design se deu por alguns nomes que, nas décadas de 1950 e 1960, investiram na produção de projetos próprios, como é o caso de Michel Arnoult e Zanine Caldas.

Apesar do desacerto entre essas situações de meios produtivos, pode-se dizer que o design do móvel se insere nos processos industrial, manufatureiro e artesanal. $\mathrm{O}$ artesanal é desenvolvido por um único artesão e na técnica do trabalho manual, que efetua a fabricação do início ao fim; o manufatureiro diz respeito às técnicas manuais e artesanais aplicadas numa produção em pequena escala; por fim, o industrial, aquele que utiliza força mecânica e padrão de componentes, por meio de operações e técnicas de racionalização. 
Há também outra situação. O surgimento das chamadas "novas tecnologias", que no limiar dos séculos XX e XXI despontaram quase como uma subversão aos padrões predeterminados dos processos produtivos industriais. Hoje, a grande indústria comporta a chamada produção personalizada ou de produto único. Isso quer dizer que existe uma produção dita "artesanal" inserida nos processos industriais. Outra possibilidade é aquela propiciada por máquinas de CNC e por sistemas CAD/CAM. Nesta, os processos de concepção e fabricação, antes separados por funções específicas dentro do processo industrial, tornam-se quase artesanais, porquanto possibilitam que o produto seja concebido e produzido por apenas uma pessoa, e mais, que seja alterado de forma simultânea, entre concepção e fabricação.

\section{a) Etel Marcenaria (1987) - a arte da marcenaria}

A utilização do processo produtivo artesanal na contemporaneidade é dada não só pelas características de suas técnicas executivas, mas, sobretudo, pelo valor simbólico que agrega e apresenta o objeto. Nesse caso, o valor simbólico está diretamente relacionado à tradição histórica que este ofício instaurou no Brasil.

Segundo Santos (1995:17), a substituição gradual da tradição de utilização da madeira e da técnica artesanal pelos processos industriais não foi de toda prejudicada, devido ao (res) surgimento de "uma verdadeira tradição do móvel em madeira no Brasil, que voltará a emergir, com muita força, na obra de alguns designers do século XX". Isso, segundo Cavalcanti (2001, p. 252-253), significa dizer que na contemporaneidade há a conservação da valorização do caráter técnico artesanal na produção de móveis, dada a incorporação do homem ao trabalho manual (fazer manual); utilização da madeira como matéria-prima; e pela legitimidade simbólica da técnica aliada ao material na cultura material brasileira.

$\mathrm{Na}$ contemporaneidade, a atividade artesanal (fazer artesanal por técnicas manuais) pode ser considerada aquela em que há a distinção entre as figuras do que concebe e do que executa: o artífice. Isso ocorre de forma à existente antes da Revolução Industrial, quando não havia divisão de tarefas e aquele que criava realizava integralmente as tarefas de produção.

Vale ressaltar que a produção do móvel brasileiro contemporâneo, baseada no fazer artesanal, tem como objetivo duas condições: a primeira, como produção viável para as experimentações do design em si; a segunda, como instrumento de resgate de 
valores da tradição histórica da cultura material brasileira. Outra situação é aquela em que ao móvel artesanal é conferido valor devido à excelência do acabamento e à pequena produção, com poucos exemplares, se não um único, evidenciando assim um grande caráter diferenciador de mercado.

A Etel Marcenaria é um exemplo contemporâneo do fazer artesanal realizado com o intuito de valorizar a matéria-prima madeira e a "arte da marcenaria". Com uma equipe de artesãos formados por uma escola da própria marcenaria, a produção das peças inclui um minucioso trabalho, desde a secagem da madeira até a montagem realizada por meio de um sistema de encaixes, sem utilização de pregos ou parafusos: o alfarje.

A empresa, além de produzir suas próprias peças, também produz peças de outros designers, como Fúlvio Nanni, Claudia Moreira Salles, Paulo Milani, entre outros.

No ano de 2001, a Etel Marcenaria foi a primeira empresa moveleira brasileira a conquistar a certificação do FSC - Forest Stewardship Council (Conselho de Manejo Florestal). Desde então, todas as peças da empresa levam o "selo verde" do FSC.

\section{b) Claudia Moreira Salles (1955 -) - móveis artesanais}

Carioca, graduada pela ESDI - Escola Superior de Desenho Industrial, sua formação e experiência inicial da profissão sempre foi baseada nos princípios puros da racionalização e produção industrial em série. Em 1984, a designer passa a se dedicar ao projeto de mobiliário residencial direcionado às necessidades específicas dos usuários.

Claudia Moreira Salles também pode ser enquadrada na categoria já abordada: "A brasilidade no móvel", pois seus trabalhos, além de contar com etapas em que a produção artesanal é valorizada, revelam peças que se aproximam de certas referências da cultura brasileira tradicional: a manipulação da madeira e o desenvolvimento de encaixes, malhetes e marchetarias.

Uma grande característica dos trabalhos da designer é a combinação da madeira, que por natureza é densa e pesada, com peças providas de desenhos que transmitem leveza visual. Esse resultado é obtido por meio da "transparência", com a utilização de espaços vazios, o que se pode ver através das peças e recortes.

Atualmente Claudia é considerada também uma designer que segue as tendências contemporâneas da utilização racional dos recursos naturais. Usa madeiras 
oriundas de demolição, tacos de pisos já utilizados, e reaproveita sobras de madeiras de outras produções.
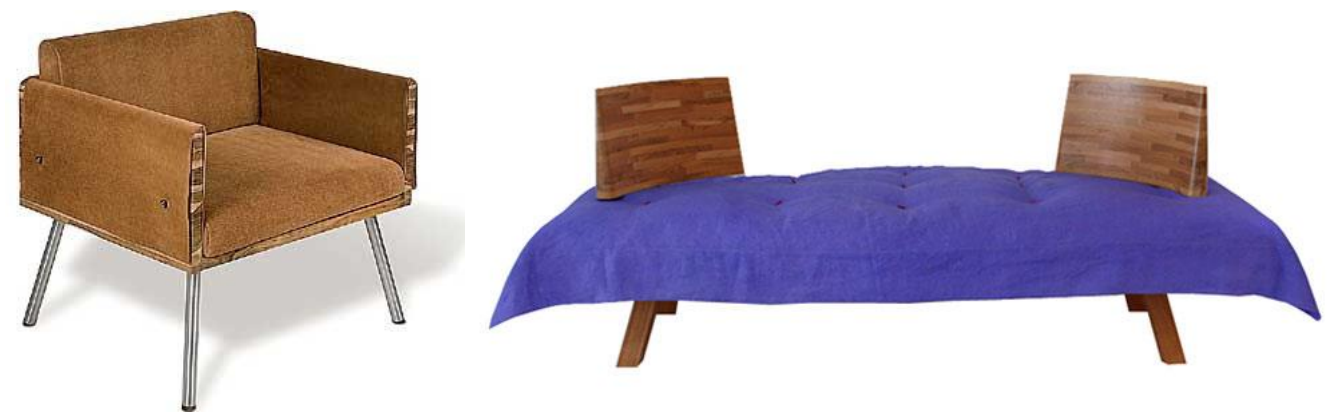

Figura 70 - Poltrona Casta (2006), totalmente desmontável, e banco Siri, 2008, uma namoradeira contemporânea com encostos giratórios que permitem o acesso de ambos os lados, produzida com restos de madeira maciça

c) MuiraDesign (2005)

Projeto desenvolvido por um grupo de pesquisa da Universidade de Brasília com o objetivo de promover a técnica tradicional de marchetaria como componente de valor na produção moveleira. Os designers projetaram uma linha de móveis nos quais foram aplicados "módulos" ou "azulejos" de $15 \mathrm{~cm}$ x $15 \mathrm{~cm}$ marchetados em lâminas certificadas de madeiras alternativas da Amazônia. Os módulos são usados como um "gabarito" que permite a padronização, evitando assim os defeitos e reduzindo os custos de fabricação das marchetarias. O uso de desenhos simplificados tornou mais fácil o corte das lâminas ${ }^{37} \mathrm{e}$ montagem das peças. Entretanto, apesar de serem padronizados, tanto os módulos quanto os desenhos das lâminas das madeiras permitem uma variedade de padrões conforme a escolha e a sequência de montagem do artesão ou do próprio cliente.

Segundo os autores do projeto, as imagens simbólicas de referência da cultura tradicional e popular foram fontes de inspiração para a criação dos padrões e dos móveis. O direcionamento projetual foi baseado na referência sígnica dos elementos da cultura material encontrada nas bases do design do móvel brasileiro.

A utilização de referências baseadas nos códigos visuais da cultura popular brasileira; nos materiais que referenciassem o sentimento nativista e na técnica que

\footnotetext{
${ }^{37}$ As lâminas das madeiras são cortadas por meio de processos de corte aplicados na indústria gráfica.
} 
remetesse ao artesanato e ao fazer manual são aspectos determinantes que deram ao projeto o conceito contemporâneo de produtos que não apenas devem ser usados, mas também contemplados.

A utilização de referências simbólicas da ideia de "brasilidade" foi o aspecto mais relevante no desenvolvimento do processo de configuração tanto dos padrões quanto dos móveis, pois localiza a dialética entre universal e nacional - geral e particular - tão discutida na contemporaneidade.

A produção utilizada é a semiartesanal. O projeto trabalha com lâminas de madeiras cortadas pela indústria gráfica, o que traz melhor controle na qualidade do corte e das dimensões, que são coladas sobre uma superfície em madeira processada industrialmente (MDF) que, por sua vez, montam um painel de dimensões variadas, obedecendo ao padrão de $15 \mathrm{~cm}$. Esse processo de colagem e montagem é feito por marceneiros/artesãos e admite que a variedade e não a monotonia, tão defendida por John Ruskin (1989), seja explorada.

O projeto MuiraDesign aplica o ornamento em marchetaria como design de superfície e é um exemplo de fabricação semiartesanal ou manufatureira utilizado na produção do mobiliário contemporâneo.

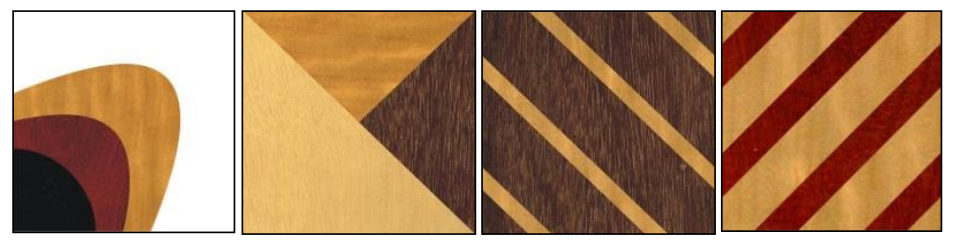

Figura 71. MuiraDesign. Módulos marchetados de $15 \mathrm{~cm} \times 15 \mathrm{~cm}$. Módulos: Barú, Pipa, Trama 1 e Trama 2, respectivamente (2005)

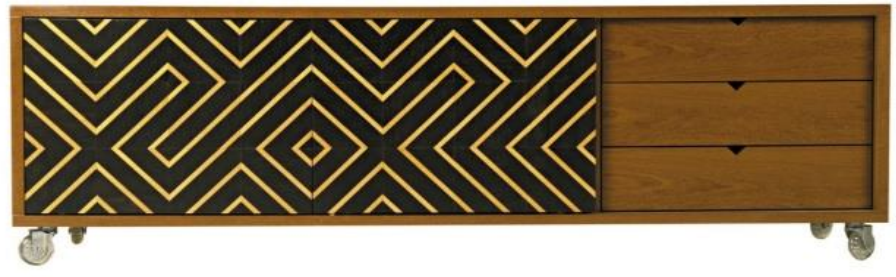




\subsubsection{Design conceito: nova geração}

O design contemporâneo brasileiro propõe um novo jeito de pensar, de retirar mobília daquilo considerado improvável. Criou-se uma categoria que vai além do uso na sala de estar e jantar. São peças que resultam num estilo bem mais conceitual, que ora se utiliza de técnicas tradicionais, ora da alta tecnologia. É o design que faz da memória afetiva o seu novo valor, com referências às brincadeiras de criança ou com o uso de materiais facilmente identificáveis. Emociona porque provoca sentidos e lembranças.

O designer tornou-se um "escultor", e a forma por ele produzida deixa de ser um simples complemento da função ou de várias atividades adjacentes ao sistema produtivo para tornar-se uma expressão individual correspondente ao novo pensamento. Philippe Starck diz que "a invenção consiste em lançar um novo olhar sobre as coisas e transformar o objeto em portador desse novo olhar”. A função não mais se resume aos elementos que indicam as funções de uso ou técnicas, “[...] mas ao olhar aleatório. Momentâneo, subjetivo, contemporâneo, que reúne todos esses elementos” (JEUDY, 1999, p. 08).

A nova geração de designers brasileiros cria exemplares fundamentados em conceitos de brasilidade, reciclagem e visão atenta às parcelas da sociedade ainda não tocadas pela globalização. No projeto de mobiliário, conseguem redefinir códigos visuais que ainda não foram totalmente atingidos pela pasteurização atual. São profissionais que permeiam com facilidade desde processos artesanais e tradicionais de fabricação, até processos com alta tecnologia.

Com o uso de cordas coloridas, ou mistura de materiais nada nobres, como plástico, nylon e fitas; com a utilização da madeira como suporte material; ou ao contrário, com o uso de novas tecnologias de fabricação e dos materiais, essa categoria por vezes consegue subverter os formatos até então conhecidos.

$\mathrm{Na}$ maioria das vezes, o que se quer é provocar. Não se sabe se aquilo que parece "poltrona" - aí reside o paradoxo - é escultura ou é para se sentar. A ideia é essa. No design contemporâneo da nova geração, a velha máxima da "forma segue a função" desapareceu. O que vale é a "simbiose" entre o indivíduo e o objeto.

Nomes como Flávia Pagotti Silva, Zanini de Zanine Caldas, Sergio Fahrer, Juliana Llussá, Jader de Almeida, Super Limão, Fetiche Design, entre outros, compõem o elenco de designers e estúdios representantes dessa geração. 
Flávia Pagotti Silva (1971), utilizando-se de detalhes e desenhos tradicionais como os traços da renda filé ou de azulejos portugueses, os aplica em materiais de alta tecnologia e fabricação, como o Corian ${ }^{38}$. A maior característica da designer é misturar expressões tradicionais distintas e "transformar o artesanato com tecnologia" (PAGOTTI, apud SANTANA, 2010, p. 210).

Zanini de Zanine (1978), outro representante, não segue um padrão ou estilo predeterminado. Projeta peças em madeira, materiais e técnicas tradicionais ou naqueles que exigem alta tecnologia, como plástico rotomoldado. Segundo o próprio designer, utiliza duas maneiras básicas para criar. A primeira é quando um desenho nasce de uma inspiração e se projeta no papel, para em seguida definir qual o material mais adequado até chegar à forma desejada. Ou, ao contrário, define a matéria-prima e passa para a fase de perceber quais contornos e linhas o material oferece para que a construção aconteça. Ao mesmo tempo em que suas peças são projetadas pela "inspiração", necessitam por parte do designer de um conhecimento profundo dos materiais e processos técnicos de produção.
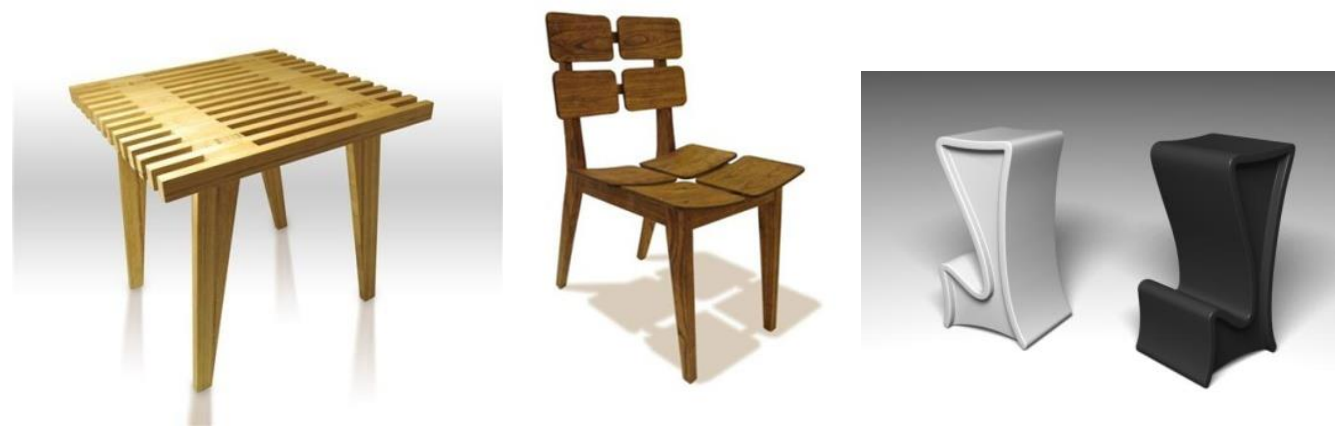

Figura 73 - Mesa Ripa, Cadeira Quadri e Banco Bar, de Zanini de Zanine Caldas

\footnotetext{
${ }^{38}$ Corian é marca registrada da DuPont ${ }^{\mathrm{TM}}$. É um material sintético, derivado da combinação de minerais naturais e polímero acrílico puro, que possibilita várias formas de modelagem e aplicação.
} 

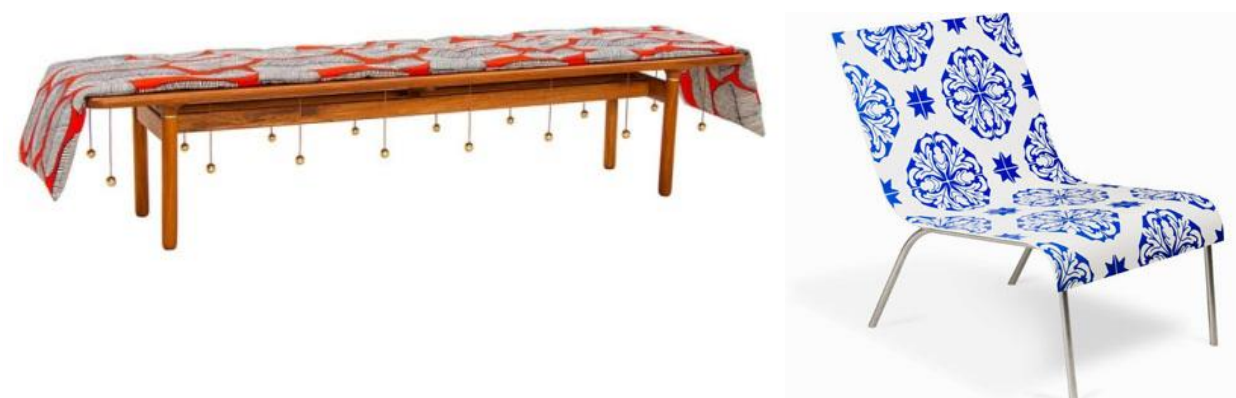

Figura 74 - Banco Boleadeira (2013) e Poltrona São Luís (2007), de Flávia Pagotti

Assim, esse panorama essencialmente histórico apresentado na parte II do trabalho, analisou o período compreendido entre a colonização do Brasil até meados do século XXI, e nos auxiliou sobremaneira a identificar como foram as relações e as proposições que marcaram o design do mobiliário brasileiro dentro dos conceitos que margeiam o design emocional. 


\title{
PARTE III - A EMOÇÃO NO DESIGN DO MÓVEL BRASILEIRO
}

\begin{abstract}
Quem conhece o solo e o subsolo da vida sabe muito bem que um trecho de muro, um banco, um guarda-chuva são ricos de idéias ou de sentimentos, quando nós também o somos, e que as reflexões de parceria entre os homens e as coisas compõem um dos mais interessantes fenômenos da terra. (Machado de Assis, Quincas Borba, 1891)
\end{abstract}

Após a efetivação de um referencial teórico e histórico, propostos nas partes I e II, com vistas a proporcionar o embasamento conceitual indispensável para $\mathrm{o}$ desenvolvimento do trabalho e com o objetivo de promover o entendimento das articulações realizadas entre os diversos assuntos abordados, propomos agora uma apreciação mais específica para o problema em questão.

Esta sessão apresenta uma análise de três peças do mobiliário brasileiro que consideramos pertencentes à categoria dos “objetos emocionais" por nós definida. O objetivo desta análise é demonstrar e articular os pressupostos até aqui apresentados junto à realidade cotidiana, nos objetos, onde acontece a relação entre o indivíduo e o objeto.

É fato que as peças selecionadas não fazem parte atualmente do cotidiano anônimo, mas já pertenceram, ou poderiam pertencer.

Por serem portadoras de qualidades relacionadas e abertas aos processos de significação, possuem características que se destacam não como objetos "verdade”, mas como aqueles a serem "usufruídos" pelo indivíduo, numa relação dialógica e intersubjetiva. 


\section{MOLE, VERMELHA, SIRI: CONCEITOS “MÓVEIS”}

Após levantarmos e pontuarmos os conceitos que nos nortearam à discussão acerca da relação entre objeto e indivíduo dentro de uma relação emocional, e utilizando o mobiliário brasileiro como estudo de caso, partimos para determinar a metodologia que nos guiou a análise.

Primeiramente selecionamos as peças, em seguida determinamos um roteiro, e por fim, os conceitos norteadores que nos levaram ao desenvolvimento da análise em si.

Assim, estes foram os critérios que nos levaram à seleção dos móveis:

a) Peças que foram projetadas em diferentes períodos e diferentes contextos. Esse critério se deu por acharmos conveniente um confronto dos períodos em que os projetos aconteceram - a saber: década de 1950, período em que o modernismo estava aflorando no Brasil; anos 1990, época das discussões pós-modernas; e 2008, considerado momento contemporâneo;

b) Peças que, em princípio, foram projetadas com um conceito de produção artesanal, mas que permitem serem produzidas industrialmente ou, pelo menos, em série programada;

c) Peças que pedem uma aproximação individual e particular;

d) Peças que pertencem a uma mesma categoria tipológica de uso - descanso. A metodologia para a análise das peças foi baseada em:

a) Estudos das peças encontradas no mercado e em uso (interação com as peças) objeto real;

b) Material bibliográfico acerca das peças e de seus autores;

c) Imagens das peças, encontradas em livros, revistas e catálogos dos fabricantes;

d) Imagens do uso das peças em diversas situações e ambientes, encontradas em catálogos, revistas de decoração, fotografias e em situação real;

Partindo da prerrogativa já citada de que os objetos possuem características objetivas e subjetivas, construímos então três categorias de fatores que nos auxiliaram a entender como a relação emocional, sob a perspectiva da influência que as funções dos objetos operam sobre o indivíduo e constituem o próprio objeto, é dada pela interação de indivíduo e objeto. Será por meio da análise da forma "apresentada" pelos móveis e suas relações que desenvolvemos esses tópicos. 
Inicialmente faremos uma análise baseada numa sequência de descrição dos elementos que formam os móveis: seus materiais, dimensões e partes que os compõem, e algumas particularidades quanto à produção e fabricação, ou seja, uma análise da situação material do objeto. A segunda fase é de organização e entrecruzamento desses elementos descritos acima dentro do contexto(s) de uso(s) em que o móvel foi criado e inserido para, numa terceira etapa, constituir um nível mais concreto de percepção de sentidos, que é a experiência ou a interação dos objetos com o indivíduo.

Os móveis selecionados para a análise são: Poltrona Mole (1957/1961) de Sergio Rodrigues; Cadeira Vermelha (1993/1998) dos Irmãos Campana; e Banco Siri (2008) de Claudia Moreira Salles.

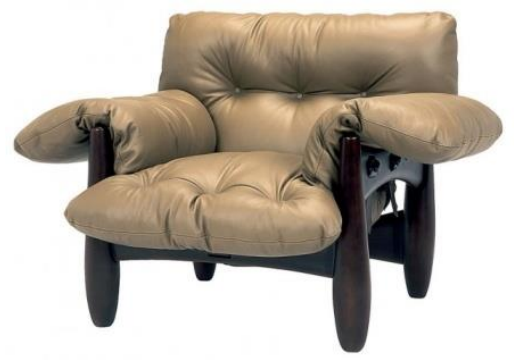

Figura 75 - Poltrona Mole de Sergio Rodrigues (1957/1961)

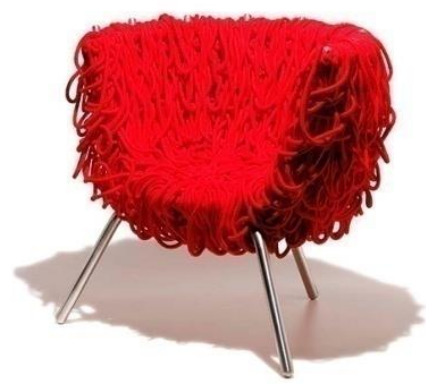

Figura 76 - Cadeira Vermelha de Irmãos Campana (1993/1998)

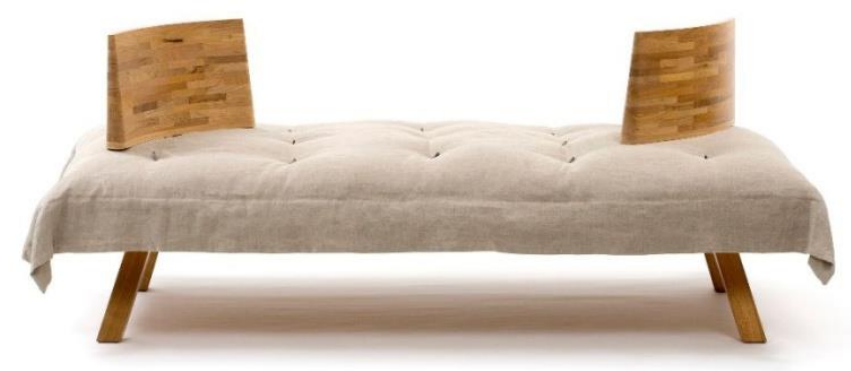

Figura 77 - Banco Siri de Claudia Moreira Salles (2008) 


\subsection{Poltrona Mole}

Criada em 1957 e redesenhada em 1961, a Poltrona Mole é considerada a obra mais importante de Sergio Rodrigues. Foi a primeira peça de um designer brasileiro que passou a integrar a coleção de Design do MoMA em Nova Iorque, em 1974.

\section{a) Descrição dos elementos}

A Poltrona Mole teve seu nome atribuído devido à sua característica "molenga". Possui uma forma robusta e esparramada. É composta por um estofado de couro macio, sem estrutura interna, que se apoia numa trama de cintas também em couro de sola suspensas por uma estrutura de madeira maciça. É um móvel largo e baixo, com altura de $75 \mathrm{~cm}$, largura de $110 \mathrm{~cm}$ e profundidade de $100 \mathrm{~cm}$. Essas dimensões fazem que a poltrona tenha um aspecto mais horizontal.

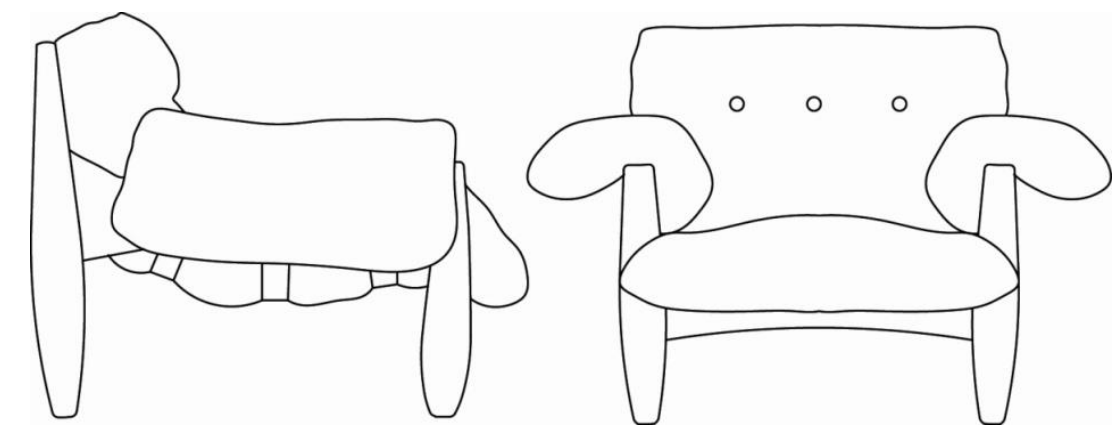

Figura 78 - Dimensões da Poltrona Mole, (L) $110 \mathrm{~cm}$ x (P) $100 \mathrm{~cm} \times(A) 75 \mathrm{~cm}$

Outro ponto de destaque da forma da Poltrona Mole é o seu aspecto roliço, sem quinas vivas. Os 4 pés do móvel são sólidos "bojudos" de revolução e as 5 travessas que estruturam os 4 pés possuem todas as quinas muito arredondadas. 


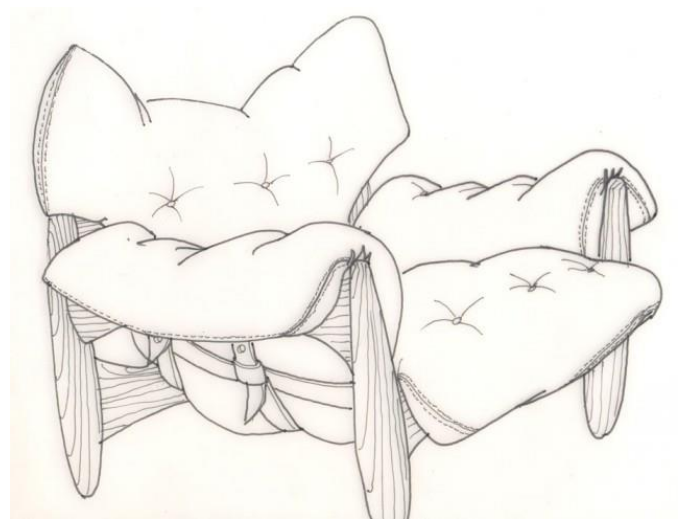

Figura 79 - Desenho de Sergio Rodrigues da Poltrona Mole

A Poltrona Mole é completamente desmontável, pois utiliza a antiga técnica do alfarje, por meio de respiga como união das peças e pode ser separada em 3 partes gerais: 1 estofado inteiriço; 1 trama com 7 cintas e 14 botões; 5 travessas, sendo 1 frontal, 2 posteriores e 2 laterais; e 4 pés, 2 dianteiros menores e 2 traseiros, maiores.

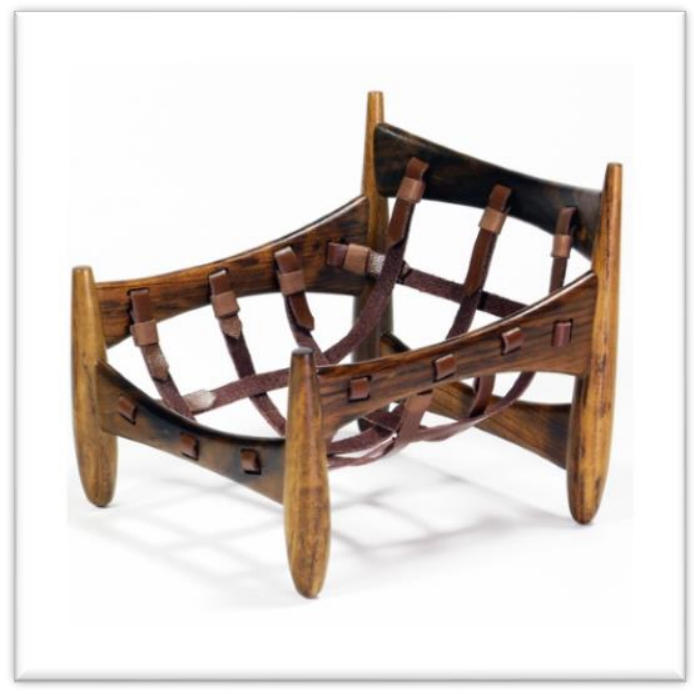

Figura 80 - Estrutura fixa da Poltrona Mole 


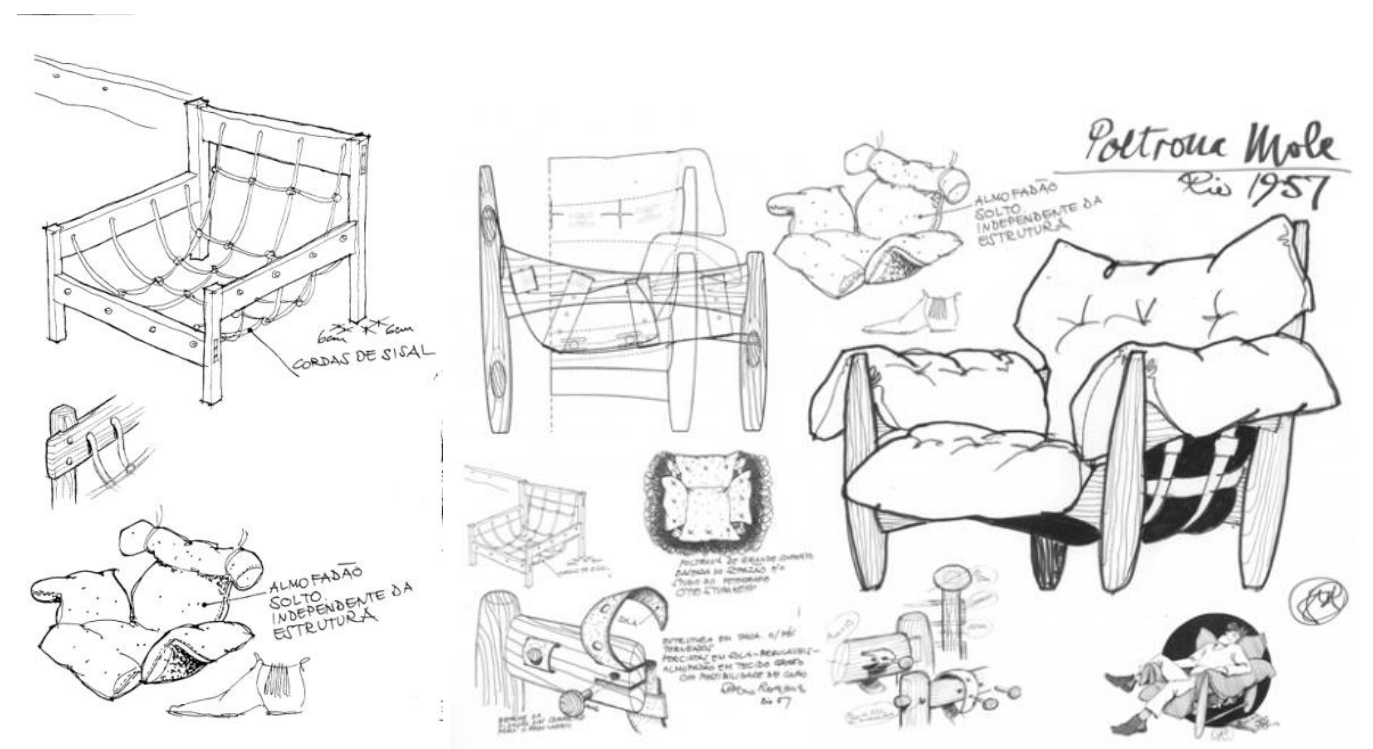

Figura 81 - Desenhos esquemáticos e ilustrativos da Poltrona Mole realizados por Sergio Rodrigues

O estofado é uma peça inteiriça, semelhante a um almofadão, recheado de espuma de poliuretano e revestido de couro no tom caramelo, preto ou branco, ou por tecidos variados, como o jeans. Quando questionado sobre o diversificado uso de tecidos e cores que estão sendo utilizados atualmente para o revestimento do almofadão, Rodrigues falou: "[...] só não pode usar o courino [...]"39, referindo-se ao material de pouca qualidade e extremamente vulgar que é encontrado no mercado. Vale lembrar que a primeira versão da poltrona foi produzida com tecido artesanal e só posteriormente foi lançada em couro ${ }^{40}$. Esse almofadão possui 3 capitonês no encosto, 3 no assento e 3 em cada apoio de braço.

A trama é composta por 7 cintas em couro de sola, sendo 4 no sentido longitudinal do móvel e outras 3 no sentido transversal, formando assim uma malha bastante segura. Cada uma das cintas recebe vários furos, permitindo que o comprimento seja regulado. Um parafuso de madeira é responsável pela fixação da cinta na estrutura. Esta regulagem permite que o usuário defina a profundidade e consequentemente o uso do móvel, possibilitando que ora se deite, ora se sente.

A Poltrona Mole possui 5 travessas, sendo 2 laterais, 1 frontal e 2 posteriores. As travessas são de madeira maciça, cujo tipo pode variar de acordo com o ano de produção do móvel. As primeiras poltronas, por exemplo, eram produzidas com Jacarandá da Bahia, no entanto, como essa espécie está em extinção, hoje é utilizado o

\footnotetext{
${ }^{39}$ Entrevista dada por Sergio Rodrigues a Airton Costa Jr, em agosto de 2013.

${ }^{40}$ Disponível em: <http://blogs.estadao.com.br/casa/uma-vida-para-o-design/>.
} 
Tauari $^{41}$ de reflorestamento, tingido no tom tabaco ou em sua cor original (mais clara) para a confecção do móvel. Cada uma dessas travessas possui um formato acinturado, mais estreito no centro e mais largo nas extremidades; fora isso, todas as quinas das travessas são bastante arredondadas. Estas peças também possuem recortes e furações que permitem a fixação das cintas e parafusos no móvel.

Os quatro pés da Poltrona Mole seguem o mesmo material que as travessas, a madeira maciça. Os dois pés frontais são mais baixos e têm uma forma bojuda, mais espessa na base e fina na ponta superior.

Para finalizar a estrutura, a Poltrona Mole possui 14 parafusos torneados em Tauari, que fixam a trama de cintas na estrutura principal.

Atualmente a Poltrona Mole é produzida de forma industrial sob a supervisão da Lin Brasil ${ }^{42}$, empresa que gerencia a produção dos móveis de Sergio Rodrigues. Dado o aspecto artesanal de vários elementos da Poltrona Mole, a Lin Brasil trabalha com uma rede de fornecedores capazes de entregar o móvel da maneira que foi projetado. Exceto o tipo de madeira e a maior variedade encontrada no acabamento do almofadão, a Poltrona Mole encontrada hoje no mercado é idêntica às produzidas em meados dos anos 1960.

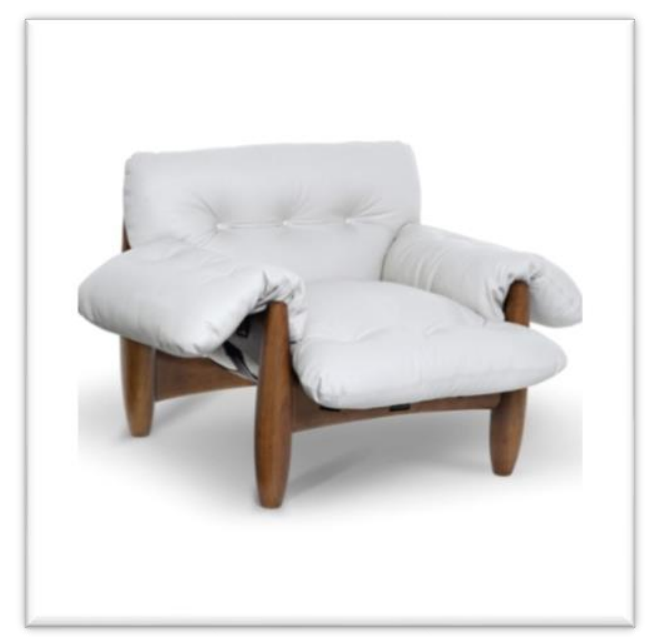

Figura 82 - Poltrona Mole na versão em couro da cor branca e Tauari tingido

\footnotetext{
${ }^{41}$ A madeira de Tauari é moderadamente macia ao corte, apresentando um bom acabamento, apesar de a superfície ficar às vezes com aparência felpuda. Algumas espécies possuem sílica, o que contribui para desgastar a afiação das ferramentas. É extraída de florestas manejadas e é uma madeira ecologicamente correta. Disponível em:<http://www.basesolida.com.br/madeira/tauari-detail >.

${ }^{42}$ Disponível em:<http://www.linbrasil.com.br/>.
} 
Atualmente as peças de Sergio Rodrigues são produzidas com tecnologia de ponta, como tornos e fresadoras assistidos por computador. Os desenhos foram digitalizados e toda a usinagem da madeira é realizada de forma rápida e eficiente, diferentemente do passado, quando a Poltrona Mole era produzida de forma artesanal com ferramentas básicas de marcenaria como plaina, torno, serra e tupia. ${ }^{43}$

\section{b) Contexto(s) de uso(s)}

É um móvel projetado para o relaxamento. Em 1957, o briefing que originou a poltrona, do fotógrafo Otto Stupakoff para o Sergio Rodrigues, era bem claro quanto ao conforto. O fotógrafo dizia: "Sergio, bola aí um sofá esparramado, como se fosse um sultão[...]" (CALS, 2000, p. 47). Essa solicitação foi levada a cabo e culminou numa poltrona muito confortável, utilizada em ambientes mais descontraídos, onde é possível adotar uma postura mais informal.

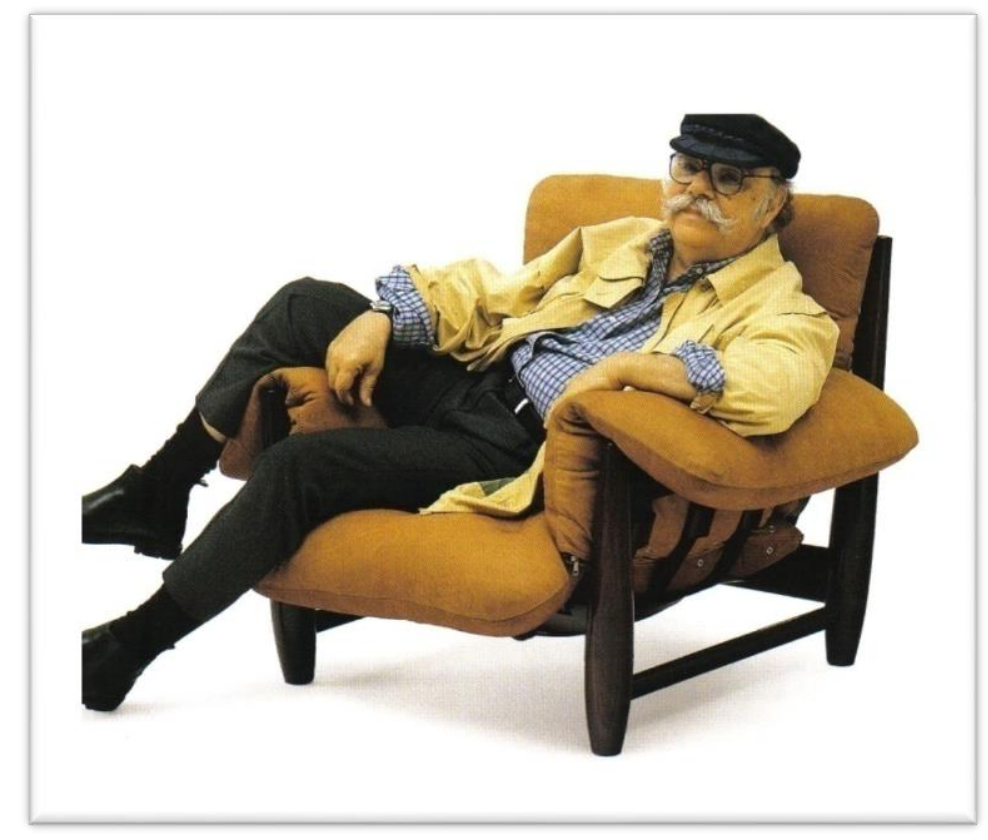

Figura 83 - Sergio Rodrigues utilizando a Poltrona Mole de forma relaxada e informal

43 Declaração dada por Jader Almeida. Almeida disse que cresceu acompanhando a produção de ícones como a poltrona Mole em marcenarias sofisticadas do Paraná. Palestra realizada em Brasília, em abril de 2012. 
A Poltrona Mole, ao contrário de algumas peças de design que são mais de experimentação que propriamente de uso, tem a sua função prática ou de uso, como móvel para se sentar, muito bem definida e eficiente. Trata-se de um móvel que cumpre bem a sua função de proporcionar conforto para quem nele se senta. Esta característica bem marcada, no entanto, não prejudicou a função semissimbólica do móvel. Pelo contrário, a Mole não só foi reconhecida, desde o seu lançamento, como simbolicamente rica, que comunica as ideias e valores do designer e de toda uma nação, mas também como um móvel que sempre propiciou uma aproximação particular, de evasão da cotidianidade.

Nota-se a presença do designer-autor em Sergio Rodrigues, apesar de muitas vezes dizer que ele era o seu maior cliente ${ }^{44}$. Fica clara a percepção das relações subjetivas e intersubjetivas que a Mole proporciona.

Vale lembrar que o contexto em que a Poltrona Mole foi desenvolvida estava saturado de um estilo de design estrangeiro: os estilos importados da Europa, advindos do período da colonização, ou os famosos pés palito e estruturas em madeira extremamente delgadas e delicadas que dominavam a produção moveleira nacional, tão evidentes nos móveis Beranger (figura 49), ou nas peças de Joaquim Tenreiro (fïgura 52). Sergio Rodrigues subverteu esse conceito estilístico de design propondo móveis com estruturas generosas de madeira, que refletiam a fartura dessa matéria-prima no Brasil, a chamada "estética da grossura". Essa leitura marcou o que seria uma das primeiras manifestações de um design autenticamente brasileiro. Isso fez com que a Poltrona Mole fosse percebida além da sua função prática, mas com sua função semissimbólica: um objeto de representação de uma identidade brasileira, um jeito descontraído de sentar e a abundância dos materiais empregados.

A Mole é um móvel bastante utilizado em contextos particulares, domésticos, onde é possível permanecer em posições mais relaxadas e descontraídas. Dada a altura e profundidade da poltrona, a posição do usuário tende ao relaxamento total e pode ser demasiado informal em contextos comerciais e administrativos. Como já comentado, a Poltrona Mole é um móvel que também está sendo tratado como objeto de arte e apresenta-se em galerias de arte e revistas especializadas de design com muita frequência.

\footnotetext{
${ }^{44}$ Entrevista dada por Sergio Rodrigues a Airton Costa Jr., em agosto de 2013.
} 


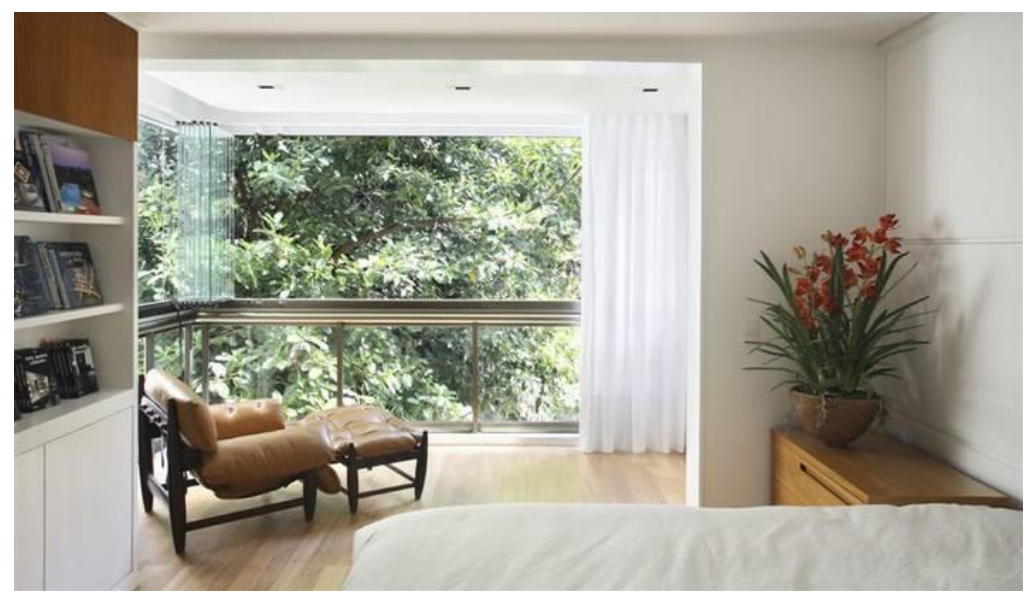

Figura 84 - Uso da Poltrona Mole em ambiente que propõe relaxamento

No contexto doméstico, a Poltrona Mole apresenta-se em ambientes internos, dadas as características da sua estrutura e estofado. Dentro de casa, a poltrona costuma ser alocada em salas de estar, gabinetes, estúdios e quartos.

É um tipo de móvel que se valorizou muito com o tempo. Seja pela sua importância na história do design brasileiro, pela qualidade dos materiais empregados, ou por suas qualidades semissimbólicas. As primeiras peças fabricadas pela Oca são perfeitamente usáveis. A utilização de madeiras nobres e do couro fez com que modelos da década de 1950 resistissem ao tempo, necessitando, vez por outra, de pequenos reparos.

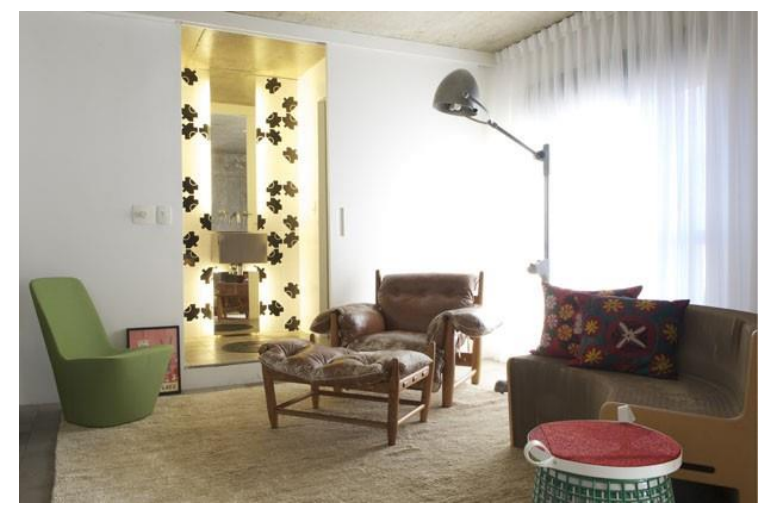

Figura 85 - Uso da Poltrona Mole original da década de 1950. Nota-se o couro desgastado e o primeiro desenho dado à poltrona

As peças produzidas atualmente, apesar de não terem o jacarandá em sua estrutura, apresentam-se com excelente qualidade de acabamento e materiais, e seguem à risca o projeto original, o que permitirá a sobrevivência e transferência da Poltrona Mole para várias gerações de usuários. 

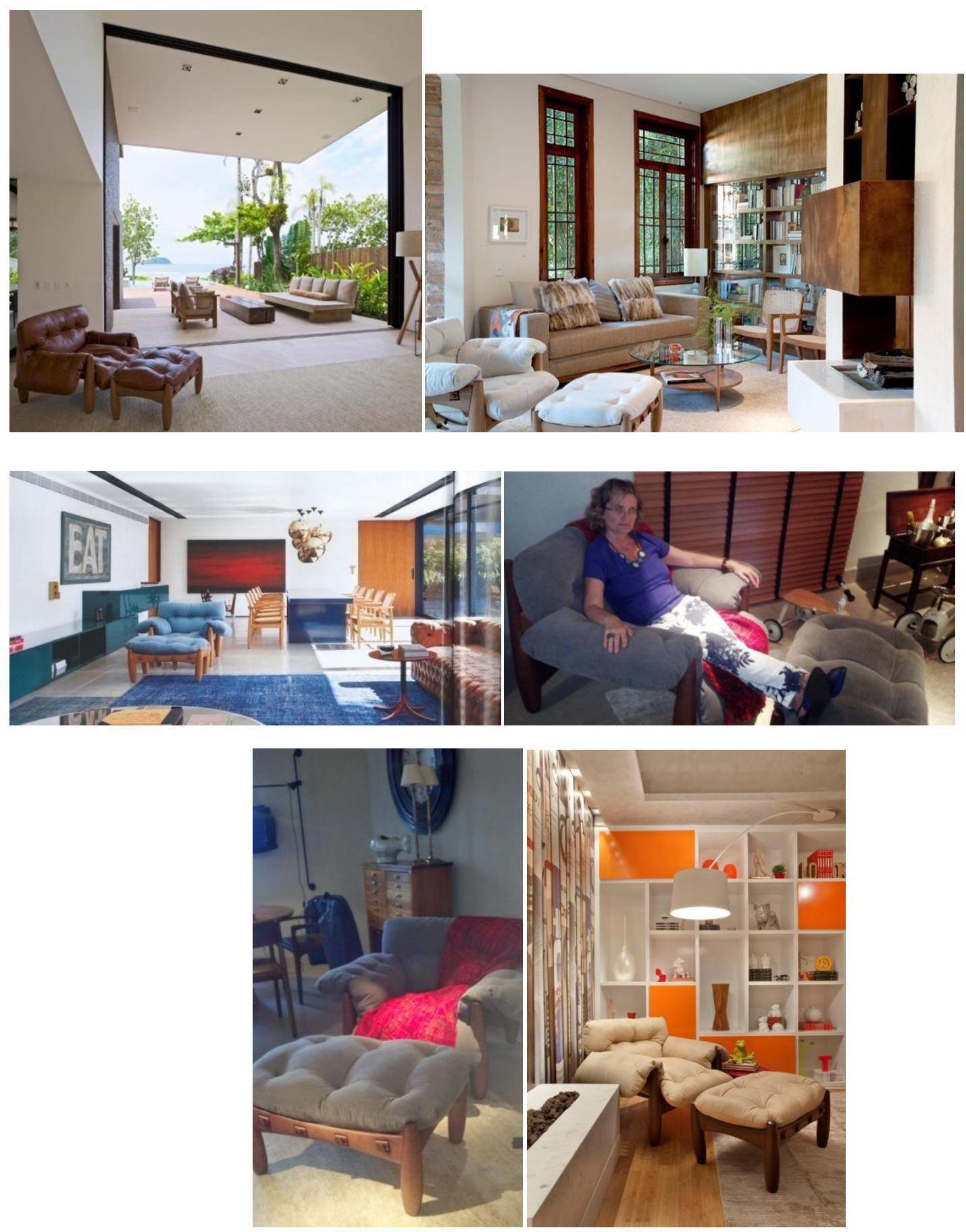

Figura 86 - Uso da Poltrona Mole em ambientes diversos e com diferentes tipos de acabamentos do Tauari e do estofado: couro, jeans e camurça sintética

\section{A familia TACAPE}

Segundo Cals (2000), a obra de Sergio Rodrigues é dividida em famílias que são constituídas por afinidades formais. A Poltrona Mole pertence à família Tacape. A principal característica dessas peças, e é o que as categoriza em uma mesma linha, são os pés torneados em forma de fuso e o uso da madeira maciça. 
A denominação Tacape foi dada pelos amigos de Sergio, Millôr Fernandes, Darcy Ribeiro e Lúcio Costa, ao se referirem que os pés da Mole lembravam os tacapes utilizados pelos índios brasileiros.

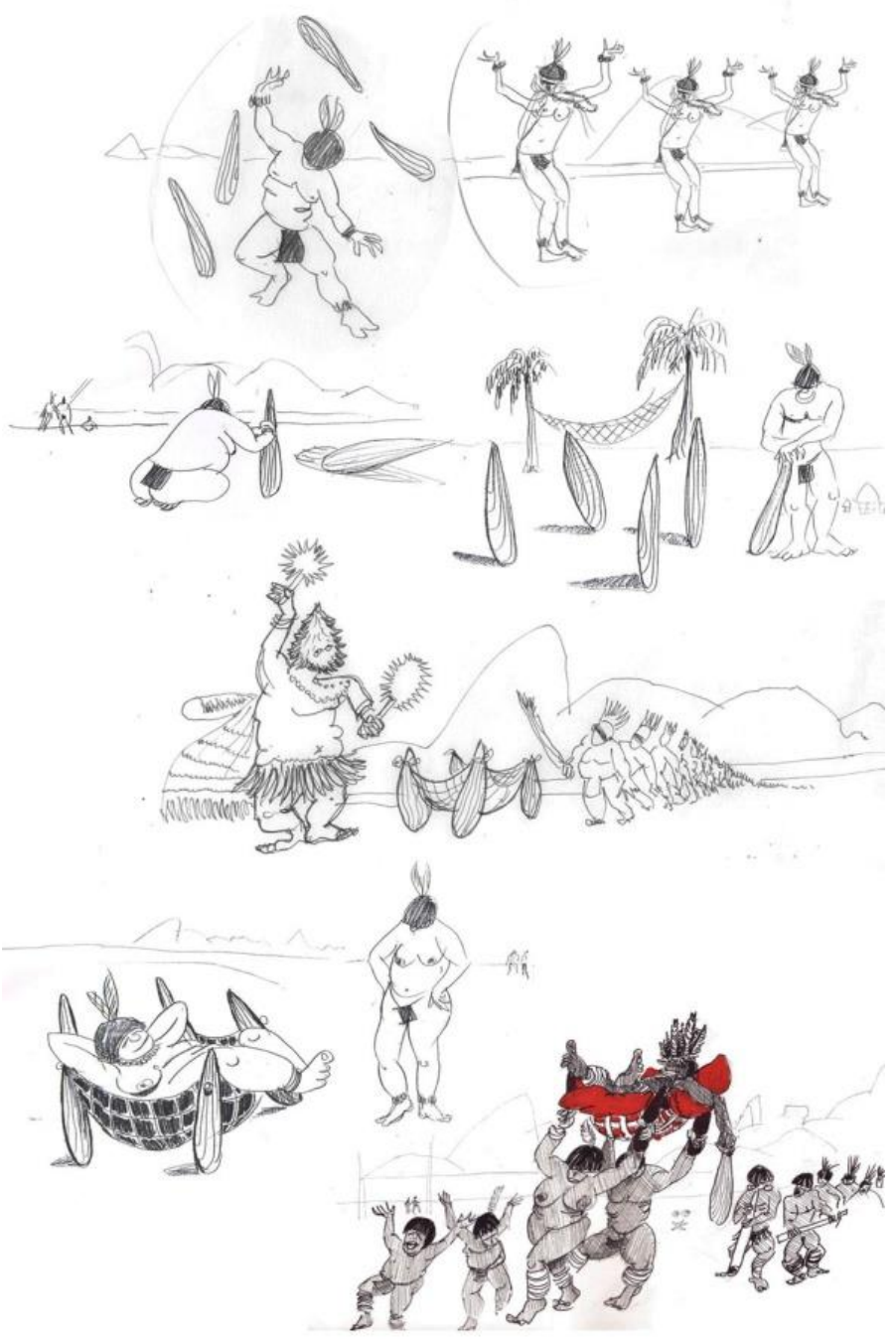

Figura 87 - Sergio Rodrigues ilustra uma simpática história sobre a criação da Poltrona Mole. Os pés do móvel, que lembram tacapes, foram o início da brincadeira.

Lúcio Costa também dizia que Sergio era um grande representante da "brasilidade", empreendedor das raízes brasileiras, que criava objetos próximos da terra, do sentar relaxado caipira e do singelo objeto indígena.

Já Santos (1992, p. 25) diz que Sergio, por meio de sua Mole, havia feito "coexistir o Brasil brasileiro [realçado por Lucio Costa] com o Brasil de Ipanema [...] na célebre "Garota de Ipanema". 
Millôr Fernandes adjetiva a Mole: “Anatômica, convidativa, insinuante. Atração fatal. Sharon Stone"; e Odilon Ribeiro, "[...] tem dengo e a moleza libertina da senzala [...]" (CALS, 2000, p. 15).

A mais espirituosa e sugestiva denominação dada à Poltrona Mole foi de Darcy Ribeiro, que a chamava de "Muié Dama" (SANTOS, 1995, p. 128).

Independentemente dos discursos nacionalistas, das falas sobre brasilidade ou das conotações "libertinas" contidas nos móveis de Sergio e, principalmente, dadas à Poltrona Mole, o fato é que ela é um móvel que sugere conforto, descontração, relaxamento e aconchego.

As peças que compõem a família Tacape são a Cadeira Cantu (1958) e Cantu Alta (1959); Banco Mocho (1954); Banco Sonia (1997); Mesa Norma (1964); Mesa Arimello (1958); Mesa Burton (1958); Sofá Mole (1957); Poltrona Mole (1957); e a Poltrona Sheriff (1961).
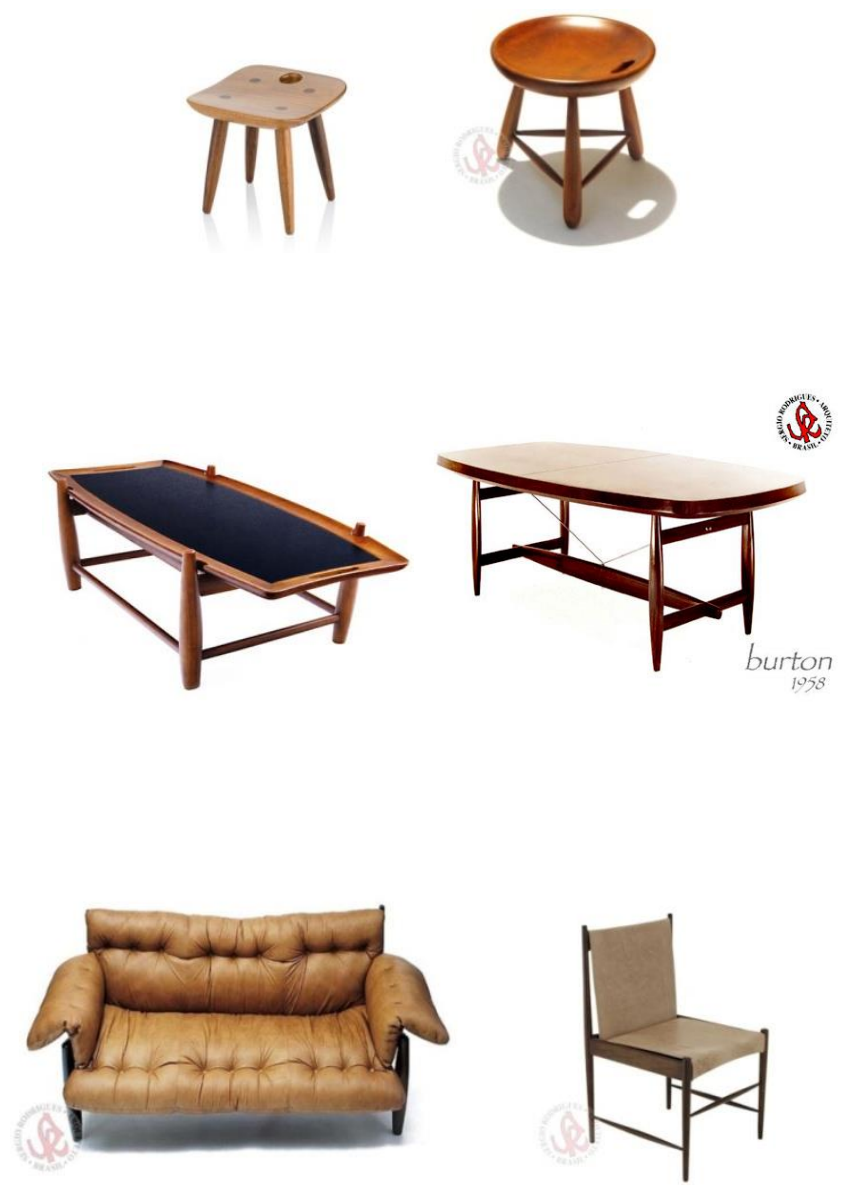

Figura 88 - Alguns exemplares da Família Tacape: bancos Sonia e Mocho; mesas Arimello e Burton; sofá Mole e cadeira Cantu 
Vale registrar que o primeiro desenho da Poltrona Mole (1957) é muito semelhante à poltrona Sheriff ou Mole (2) de 1961.45 Elas possuem os mesmos materiais e as mesmas dimensões: $110 \mathrm{~cm} \times 100 \mathrm{~cm} \times 75 \mathrm{~cm}$. O que as diferencia é o desenho das cinco travessas que compõem a estrutura. Originalmente a Poltrona Mole foi projetada com as travessas de corte reto e com outras duas travessas inferiores auxiliares para estruturação das pernas. Por já estar no mercado e ser conhecida, teve de sofrer uma pequena alteração projetual para participar do IV Concorso Internazionale del Mobile, em Cantu, Itália. Nas travessas, foram feitos cortes curvos no sentido longitudinal, deixando-as mais robustas, arredondadas e curvas, o que conferiu à poltrona uma visualidade mais condizente com a proposta do todo. Também foram retiradas as duas travessas laterais inferiores auxiliares.

A partir de então, a poltrona é conhecida no Brasil como Mole e internacionalmente como Sheriff.
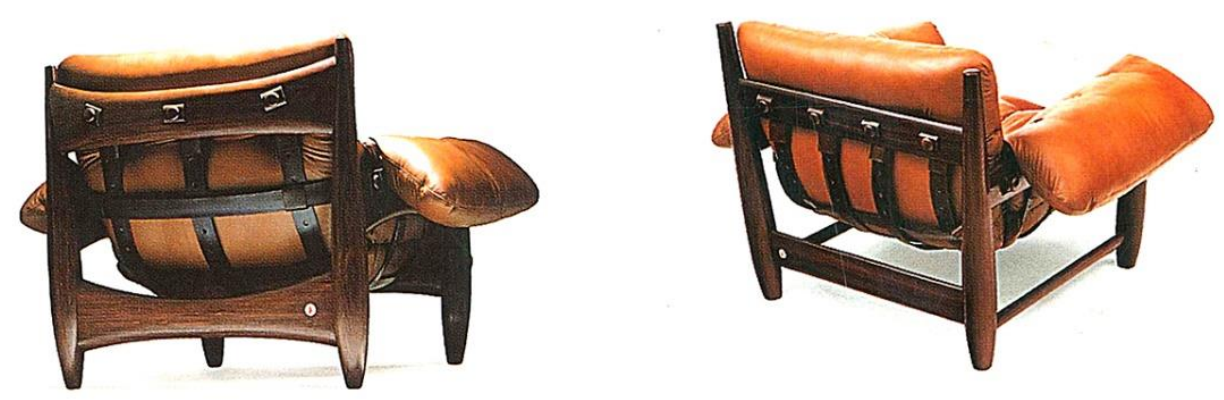

Figura 89 - Poltrona Mole (batizada fora do Brasil como Sheriff) de 1961 com as travessas curvas e a primeira versão da Poltrona Mole de 1957 com as travessas retas e as auxiliares inferiores

\section{c) Percepção}

A Poltrona Mole apresenta experiências e interações bastante interessantes que a leva à categoria de objetos emocionais. A primeira, mais visível e mais clara, é sensorial, de conforto. Essa experiência pode ser classificada dentro da condição do design visceral e comportamental de Norman (2008). O objeto proporciona, ao sentarmos nele, uma impressão de relaxamento total. Não há estruturas rígidas que incomodam o corpo, que pode se esparramar por completo, e o estofado parece abraçar

45 Sheriff foi o nome dado à poltrona Mole pela firma ISA quando adquiriu os direitos após a premiação em 1961. A Mole é conhecida internacionalmente como Sheriff até os dias de hoje. 
o usuário como um cobertor: eu abraço e sou abraçado. Trata-se de um móvel, ou de um objeto emocionalmente competente (DAMÁSIO, 2004), que permite ao usuário se sentar da maneira que quiser: deitado, sentado, esparramado, com as pernas nos encostos para os braços, dentre outros modos, estimulando assim o processo emocional e o surgimento de sentimentos como prazer e bem-estar.

$\mathrm{O}$ toque e o cheiro da madeira e do couro também proporcionam uma experiência bastante agradável, que nos remete ao tempo e às ativações de memórias e às experiências afetivas e emocionais do passado. Lembram-nos os móveis de familiares, de infância. Assim como suas dimensões. É o processo de ativação das memórias já construídas por experiências anteriores que, combinadas com as das novas experiências, geram imagens daquilo que acontece: cheiros e lembranças.

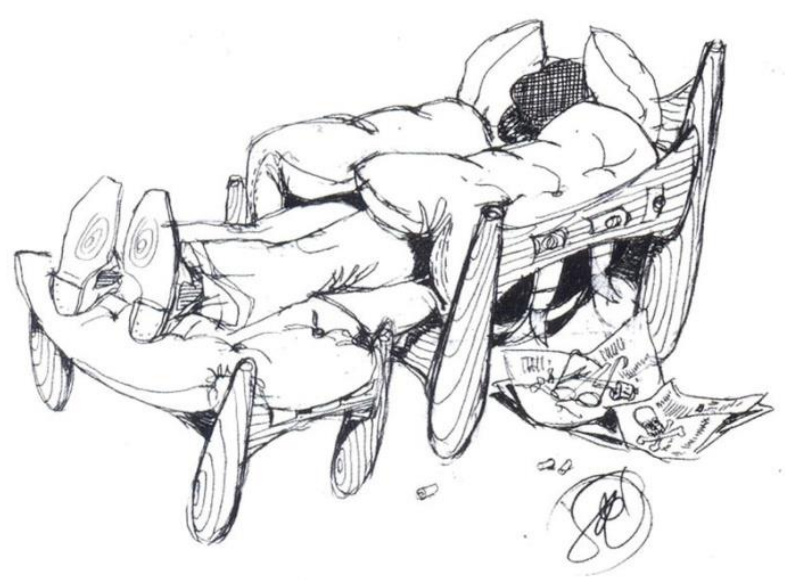

Figura 90 - Ilustração de Sergio Rodrigues demonstrando o uso "descontraído" e "relaxado" que a poltrona proporciona, e o estofado envolvendo o corpo como um cobertor

Ao defrontarmo-nos com uma peça de tamanhas dimensões, temos a impressão de estarmos presentes em locais também grandes, amplos, bem dimensionados, como as “casas grandes” dos avós ou das fazendas dos tempos de infância. Seus volumes extravagantes conferem ao móvel um aspecto de amplitude, não só das dimensões espaciais, mas também das maneiras de sentar, dos gestos e dos pensamentos, nos remetendo aos conceitos que embasaram os móveis do período de Luís $\mathrm{XV}$, que substituíram as formalidades do ritual e do formal, pela vivacidade e flexibilidade para acomodar o corpo. A Mole é um móvel que, ao nos aconchegarmos nele, nos leva à infinitude do pensamento, do sonhar acordado. 
O estofado em forma de almofadão, sem reforço interno, apoiado e solto na estrutura em trama das cintas suspensas, confere ao móvel um aspecto convidativo de conforto e suspensão, algo que remete às redes utilizadas para descansar, tão presentes no imaginário e no cotidiano brasileiro. Assim, sua estrutura e sua composição formal são condizentes com a proposta inicial de ser um móvel para se esparramar, como solicitou o fotógrafo Otto Stupakoff.

O aspecto roliço, bojudo, simples, "largado", até - porque não dizer -, "cheinho" e sem quinas vivas, enfatizam a característica tão proeminente de conforto e descanso que a poltrona transmite, diferentemente de outras poltronas, com formas longilíneas e mais estáticas que exigem uma postura mais formal e ereta dos usuários.

$\mathrm{Na}$ relação com o indivíduo que a experiencia, alguns aspectos materiais e formais podem ser destacados, enquanto funções semissimbólicas e design reflexivo.

O primeiro deles é o uso do capitonê.${ }^{46}$ Numa versão mais leve e menos rígida, de dimensões também avantajadas, a Poltrona Mole possui a aplicação desses elementos de "estilo" tão utilizados nos móveis de época para dar-lhe maior sensação de conforto, porém com as funções práticas e técnicas que eram unir o tecido da superfície ao estofamento interno e as funções semissimbólicas de representação de um estilo.
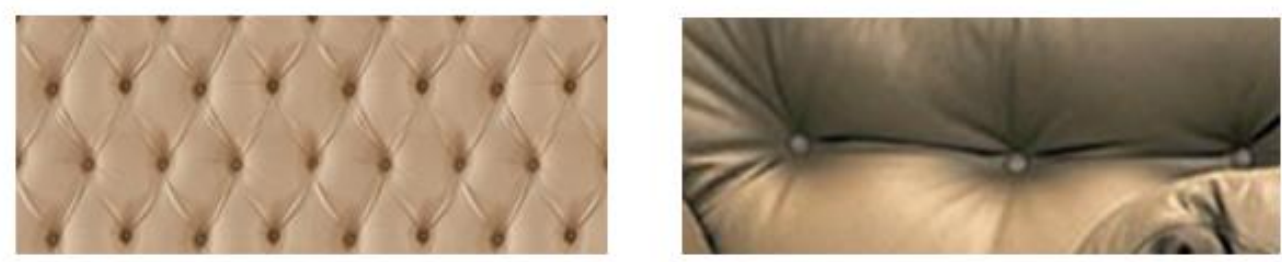

Figura 91 - Aplicação do capitonê tradicional e o aplicado na Poltrona Mole

Na Mole, o uso do capitonê também possui essa condição técnica de prender o tecido externo ao estofamento interno, contudo em menor número e com espaçamentos maiores entre si. Eles foram aplicados em linha e não formam figuras geométricas, apenas sulcos, e se localizam em posições estratégicas em que há mais contato com o usuário. Assim, o capitonê, elemento de estilo dos móveis vitorianos, é empregado de forma atualizada, nos remetendo ao passado, mas ao mesmo tempo modificando sua

\footnotetext{
${ }^{46}$ Capitonê é um tipo de acabamento que foi muito utilizado nos móveis da época Vitoriana. Seu estilo é marcante, com botões que dão acabamento à superfície acolchoada formando desenhos geométricos. $\mathrm{O}$ mais clássico e famoso móvel criado nessa linha é o icônico sofá Chesterfield, revestido em couro e com acabamento Capitonês.
} 
leitura, nos passando uma imagem atualizada e condizente com a imagem principal da poltrona: descontração e conforto.

Outro aspecto que destacamos é a contraposição entre a rigidez da estrutura de madeira e a fluidez da estrutura estofada. Comparadas a um tacape, as pernas da Mole nos passam a ideia de estacas fincadas ao chão. Já a estrutura das tramas das cintas e da almofada é solta e se movimenta. Retornamos às lembranças e referências dos equipamentos indígenas como o jirau (figura 36), que possui estrutura semelhante, e da própria rede de dormir, como já mencionados anteriormente (figura 34). Também aos móveis da colonização, como a cama catre, que possuía uma estrutura simples com quatro pés e uma trama em couro de sola servindo como próprio leito (figura 48).

Essas referências nos trazem a Mole como exemplar daquilo que foi trabalhado nos capítulos 4 e 5, quando do uso e experimentação de materiais nativos e corriqueiros, bem como a busca às raízes e práticas culturais já tão arraigadas junto ao povo brasileiro. Mais uma vez busca-se na memória a formação do indivíduo, que vai se constituindo à medida que suas experiências se acumulam.

Sob outra perspectiva, a Poltrona Mole nos aparece como uma "figura" antropomórfica: aquela que abraça, que acarinha e que aconchega; com curvas generosas e molejo no corpo.

Também aquela que se veste. A estrutura da trama das cintas é regulada por furos e passadeiras como os cintos que circundam as calças das pessoas. O estofado é produzido em diversos tecidos, cores e texturas como nossas roupas, adaptando-se assim aos nossos gostos pessoais: do clássico couro ao descontraído jeans.

A Poltrona Mole ativa nossas memórias afetivas e de referências subjetivas e intersubjetivas. Permite aos indivíduos interações tão "vivas" e "humanas" que ela própria se torna um ser: uma "Muié Dama" ou uma "Sharon Stone". 


\subsection{Cadeira Vermelha}

Meu Deus! Como é engraçado! Eu nunca tinha reparado como é curioso um laço... uma fita dando voltas. Enrosca-se, mas não se embola, vira, revira, circula e pronto: está dado o laço. É assim que é o abraço: o coração com coração, tudo isso cercado de braço. É assim que é o laço: um abraço no presente, no cabelo, no vestido, em qualquer coisa onde eu faço [...] (Mário Quintana, O laço e o abraço)

Projetada pelos irmãos Fernando e Humberto Campana em 1993, foi uma das primeiras e principais peças da dupla a serem reconhecidas internacionalmente. Assim como a Poltrona Mole, faz parte do acervo de Design do MoMA em Nova Iorque.

\section{a) Descrição dos elementos}

A Cadeira Vermelha possui uma forma semelhante a uma concha. É composta por um emaranhado de 500 metros de corda vermelha, suspenso a 38 centímetros do chão por três pés metálicos inclinados e equidistantes. A cadeira apresenta assento e encosto para braços e costas num mesmo volume, com $86 \mathrm{~cm}$ de largura e $58 \mathrm{~cm}$ de profundidade. $\mathrm{Na}$ extremidade superior da cadeira, ao redor do apoio dos braços e costas, ficam expostas 9 ponteiras metálicas que compõem o corpo da cadeira e totalizam a altura de $77 \mathrm{~cm}$ do móvel.
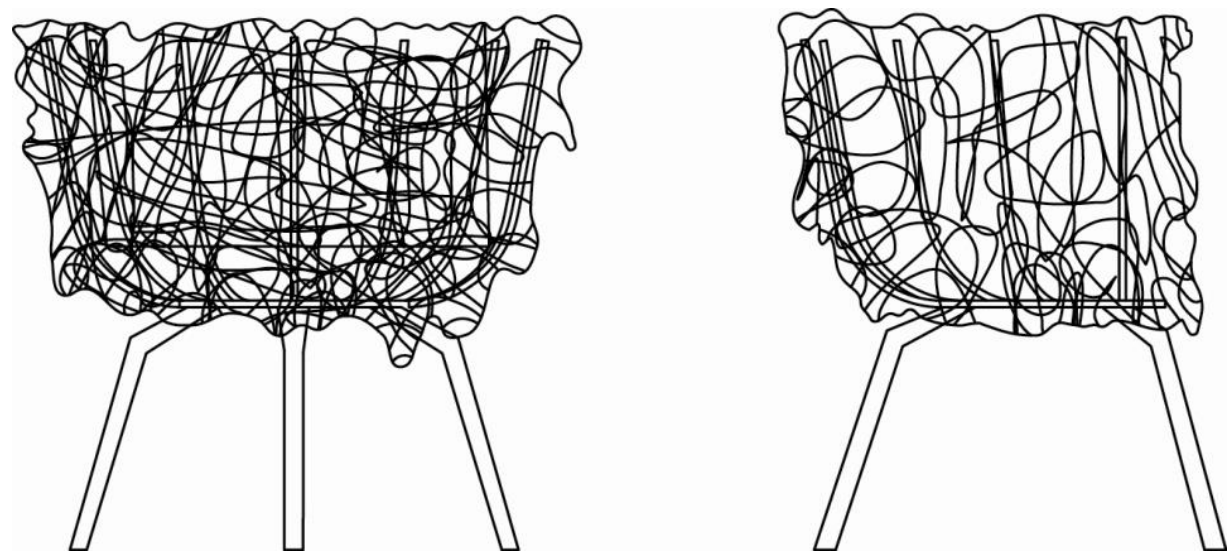

Figura 92 - Dimensões da Cadeira Vermelha, (L) $86 \mathrm{~cm} \mathrm{x} \mathrm{(P)} 58 \mathrm{~cm} \mathrm{x} \mathrm{(A)} 77 \mathrm{~cm}$

Possui uma estrutura construtiva relativamente simples, que pode ser decomposta em três partes principais: base, corpo e "estofado". 
A base é composta por 3 pés em alumínio maciço calandrados (dobrados) na extremidade superior, que são fixados ao corpo da cadeira por parafusos. A extremidade inferior, que fica em contato direto com o solo, recebe acabamento torneado, assumindo uma forma semiesférica. Vale ressaltar que as primeiras Cadeiras Vermelhas, fabricadas pelos Irmãos Campana, tinham pés de tubo em aço inoxidável, um material que, assim como o alumínio, também não oxida, e é de alto valor agregado e mais fácil de se trabalhar num contexto artesanal.

O corpo da cadeira é composto por 9 tubos em aço carbono. Esses tubos são calandrados (dobrados) para dar a correta inclinação do encosto da cadeira e dispostos de tal forma que compõem uma estrutura aramada semicircular na forma de uma concha, fundamental para o próprio desenho e ergonomia da cadeira. Esses 9 tubos que compõem o volume assento/encosto são unidos por solda a uma estrutura circular e vazada feita de chapa de aço carbono. Todas as peças que compõem o corpo da cadeira (9 tubos e a base circular) recebem uma pintura eletrostática que protege o aço contra a oxidação. Para finalizar essa estrutura, são fixadas 9 ponteiras torneadas em alumínio que integram visualmente o corpo à base do móvel.

Vale lembrar que a cadeira original era fabricada com tarugos maciços de aço inoxidável. A substituição tem uma razão de economia clara. Por se tratar de uma estrutura que fica não visível, não havia necessidade de se utilizar um material tão nobre e caro. O aço carbono, quando devidamente protegido com acabamento epóxi, obtido por meio de pintura eletrostática, garante as propriedades mecânicas do material e o protege contra a corrosão que porventura possa atacar a estrutura da cadeira, a um custo de produção mais baixo.

A terceira parte da Cadeira Vermelha é o "estofado". Ele é composto unicamente por 500 metros de corda, que tem o núcleo de acrílico e revestimento de algodão tingido. Essa corda é entrelaçada no corpo da cadeira, preenchendo todos os espaços da estrutura aramada que compõe o encosto e assento. A cadeira original, produzida pelos próprios Irmãos Campana, levava cerca de 250 metros de corda de algodão comum tingido. Essa substituição garantiu conforto, durabilidade e uma presença visual mais intensa. 


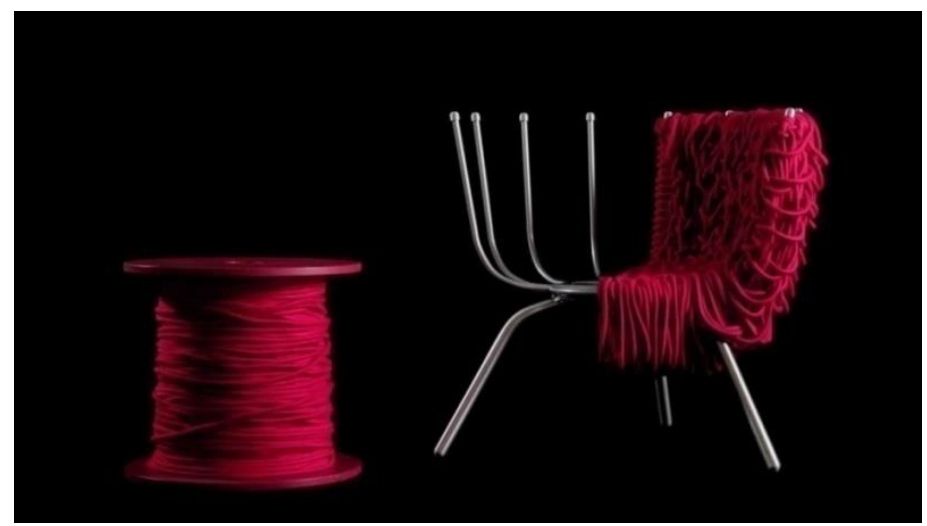

Figura 93 - Estrutura e materiais da Cadeira Vermelha - 3 pés em tubo de alumínio; 9 hastes (corpo) em tubo de aço carbono; 9 ponteiras em alumínio; e corda em fibra de acrílico e algodão formam o "estofado".

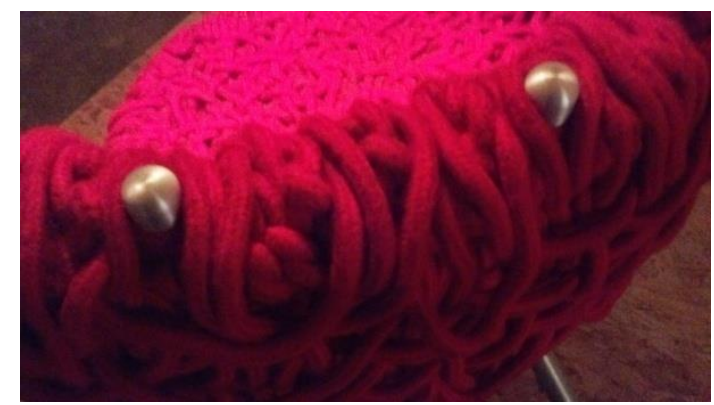

Figura 94 - Ponteiras em alumínio nas hastes que formam o encosto

A Cadeira Vermelha sofreu modificações consideráveis quando passou a ser produzida pela empresa italiana Edra, ${ }^{47}$ em 1998. O que era feito de maneira $100 \%$ artesanal, passou a ser produzido semi-industrialmente. Ou seja, processos artesanais que não agregavam valor e eram passíveis de ser executados por máquinas passaram a ser realizados de forma mecanizada. Já os processos que agregavam valor e não eram possíveis de ser executados com auxílio de máquinas, continuaram a ser executados artesanalmente, como o processo de entrelaçamento da corda para formação do assento e encosto.

A transição do processo artesanal para o semi-industrial teve um aspecto bastante curioso. Como o processo de estofamento da cadeira era gestual, ou seja, tratava-se de uma técnica baseada em movimentos específicos de laços e nós, era impossível realizar o detalhamento técnico da cadeira no formato tradicional de desenho gráfico e representação técnica, como vistas ortogonais, cortes e cotas. A solução

\footnotetext{
${ }^{47}$ A Edra é uma empresa italiana que investe na produção de peças de designers do mundo inteiro. É uma marca internacionalmente conhecida. Disponível em: $\langle$ http://www.edra.com/>.
} 
encontrada foi realizar um vídeo no qual os próprios designers explicavam passo a passo a sua execução. Essa forma de comunicação de projeto foi bastante eficiente e permitiu que a Cadeira Vermelha pudesse ser produzida fora do Estúdio dos Irmãos Campana.

A Edra, ao adquirir os direitos de produção em 1998, teve que adaptar o projeto da Cadeira Vermelha ao seu contexto produtivo, serializando alguns processos. Um exemplo da racionalização da produção da cadeira se dá na execução das suas estruturas metálicas. Como explicado, o aço inoxidável até então utilizado na estrutura dos primeiros exemplares, usinado de forma artesanal, foi substituído pelo alumínio e aço carbono com pintura epóxi, usinados em calandras e tornos de alta tecnologia, com rigorosos controles de qualidade, custo e eficiência.

O "estofado" também mudou. Como anteriormente mencionado, as primeiras peças eram fabricadas com 250 metros de corda de algodão comum, encontrada no comércio local, e foi substituída por 500 metros de corda especial, desenvolvida exclusivamente para o produto. Essa corda tem o interior em fibra de acrílico e um revestimento de algodão tingido em cores variadas, não apenas na cor vermelha. Atualmente a Cadeira Vermelha possui variação de cores e é produzida nas cores prata, dourada, preta e vermelha.
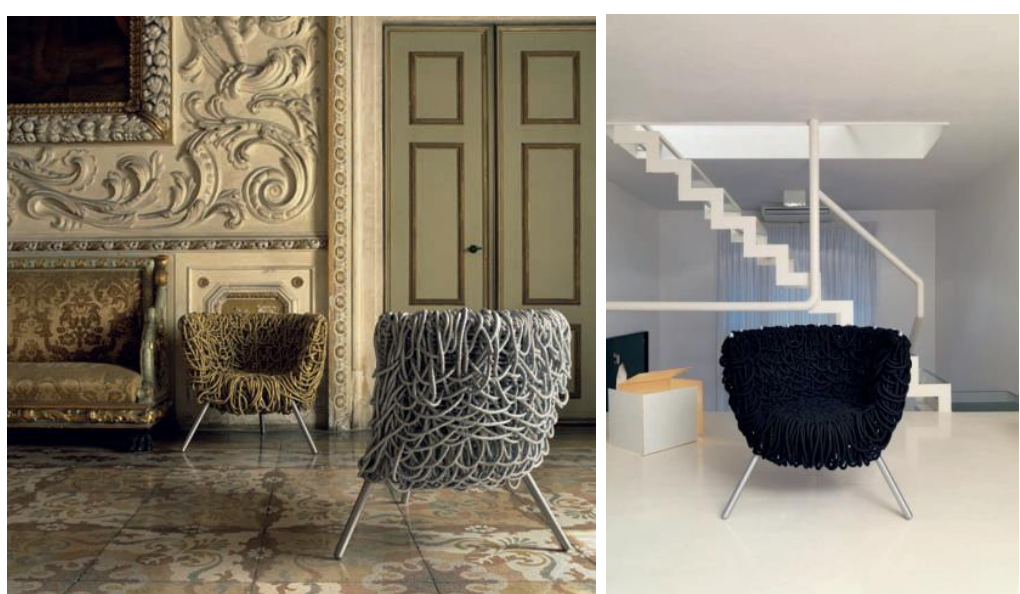

Figura 95 - Variação de cores da Cadeira Vermelha - Cor prata, dourada e preta; e ambientes diversificados de uso

O processo de "entrelaçar", apesar de se manter artesanal, foi aprimorado e leva a metade do tempo que levava para ser realizado, ou seja, cerca de 50 horas segundo a própria empresa. 


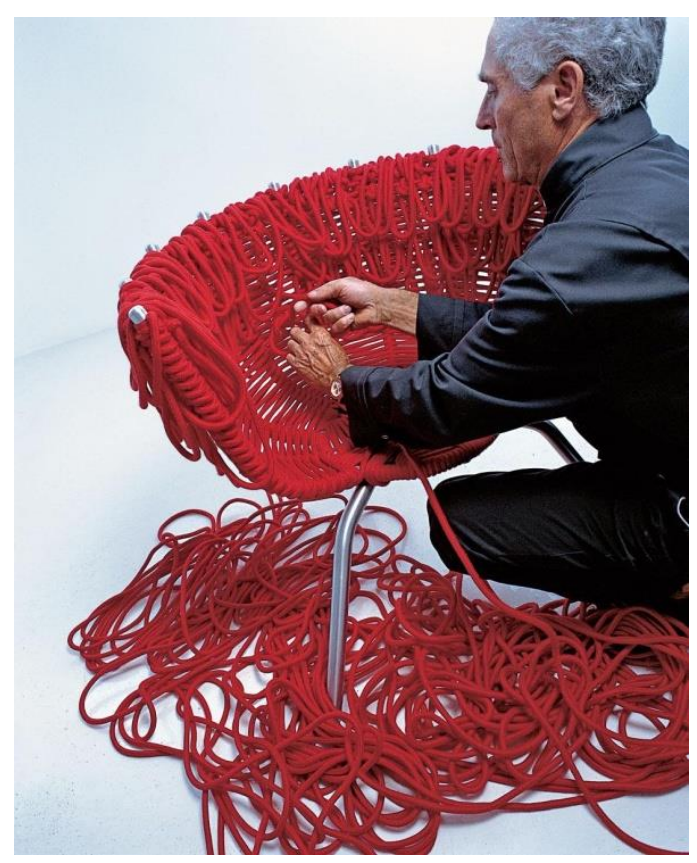

Figura 96 - Processo de entrelaçamento da corda realizado pelo artesão Giuseppe Altieri

Pode-se dizer que a Edra racionalizou o processo de fabricação da Cadeira Vermelha, pois reduziu o custo de peças que não agregavam valor, como a estrutura do assento/encosto da cadeira, e tornou o processo artesanal de estofamento mais dinâmico e eficiente. Também abriu espaço para adaptar o produto a demandas de mercado, permitindo que a cor do estofado mudasse de acordo com as tendências.

Vale ressaltar que o processo artesanal de manufatura do estofado é utilizado como um forte argumento de venda para Edra, que o explora sempre que pode em suas campanhas promocionais, tratando a Cadeira Vermelha com um produto de série limitada, disponibilizado em coleções especiais. Esse trabalho manual exigido para executar a cadeira garante a exclusividade do móvel e justifica o seu valor de mercado, que chega a ser de cerca de $\mathrm{R} \$ 38.000,00$ na empresa Firma Casa ${ }^{48}$, única revendedora dessa cadeira no Brasil.

\section{b) Contexto(s) de uso(s)}

A Cadeira Vermelha apresentou diversos usos ao longo do seu desenvolvimento. Durante a produção das primeiras cinco peças, ainda fabricadas na oficina dos Irmãos Campana, era tratada pelos designers mais como uma experiência projetual de

48 Disponível em: <http://www.firmacasa.com.br/>. 
desconstrução e experimentação do que um móvel de funções práticas ou de uso. Entre 1993 e 1998, apresentava-se como produto de imagem, ou seja, seu uso foi relacionado à promoção do trabalho dos designers, por meio de fotografias distribuídas e divulgadas junto à imprensa internacional. Segundo os próprios Irmãos Campana, em uma entrevista concedida à revista Casa e Jardim, ${ }^{49}$ as primeiras cadeiras foram um fracasso de vendas, e só passaram a vender após a empresa Edra assumir a produção e comercialização. Se por um lado, inicialmente, a Cadeira Vermelha foi um fracasso de vendas, o seu sucesso foi imediato junto à imprensa nacional e internacional. Vale destacar os artigos publicados entre 1993 e 1996 pelas revistas Domus e Abitare, ambas italianas, e a participação no livro de Mel Byars, 50 chairs: Innovation in Design and Materials (1996). Essas publicações conferiram notoriedade ao trabalho dos Irmãos Campana e chamaram a atenção de personagens centrais na carreira dos dois designers, como o diretor de arte da Edra, Maximo Morozzi, responsável pela introdução dos móveis dos Campana na indústria italiana, e a curadora de design do MoMA, Paola Antonelli, que os convidou para uma exposição e adquiriu uma das cadeiras como peça permanente no acervo do museu.

A produção comercial da Cadeira Vermelha pela empresa Edra teve um impacto forte na percepção de valor do produto. De 1998 em diante, o produto passou a compor acervos de museus internacionais como MoMA de Nova York, o Centre Georges Pompidou de Paris, o Vitra Design Museum de Rhein e a Pinakotheke Moderne de Munique, na Alemanha, tornando-se um produto com estatuto de arte e com uma imagem ainda mais forte. Ainda assim, a semi-industrialização da Cadeira Vermelha também a transformou em um produto comercialmente viável, com custos, tempo de fabricação, controles de qualidade e estratégia de preço, canais de comunicação e distribuição muito bem definidos. Foi a partir desse momento que a cadeira deixou de ser um produto essencialmente de imagem, item exclusivo de galerias e coleções particulares de design e passou a compor também a decoração de ambientes residenciais e comerciais selecionados.

Dada a importância que a Cadeira Vermelha adquiriu por meio da sua exposição em revistas, livros e museus internacionais e consagrados, o seu valor simbólico e de mercado é elevado, fazendo dela um objeto bastante exclusivo. Esta exclusividade faz

49 Edição 590 - março/2004. 
que seja utilizada mais como uma escultura, objeto de contemplação, em hall de entrada e salas de estar, do que como uma cadeira de fato, um móvel para se sentar e relaxar.

Se o uso da Cadeira Vermelha como imagem foi muito eficiente, o seu desempenho prático ou de uso apresenta algumas limitações. É possível, por exemplo, sentar-se na cadeira com relativo conforto, mas a permanência prolongada no móvel não é agradável, tendo em vista que a textura originada pela trama das cordas não é uniforme nem macia. Trata-se de uma peça de uso não rotineiro.

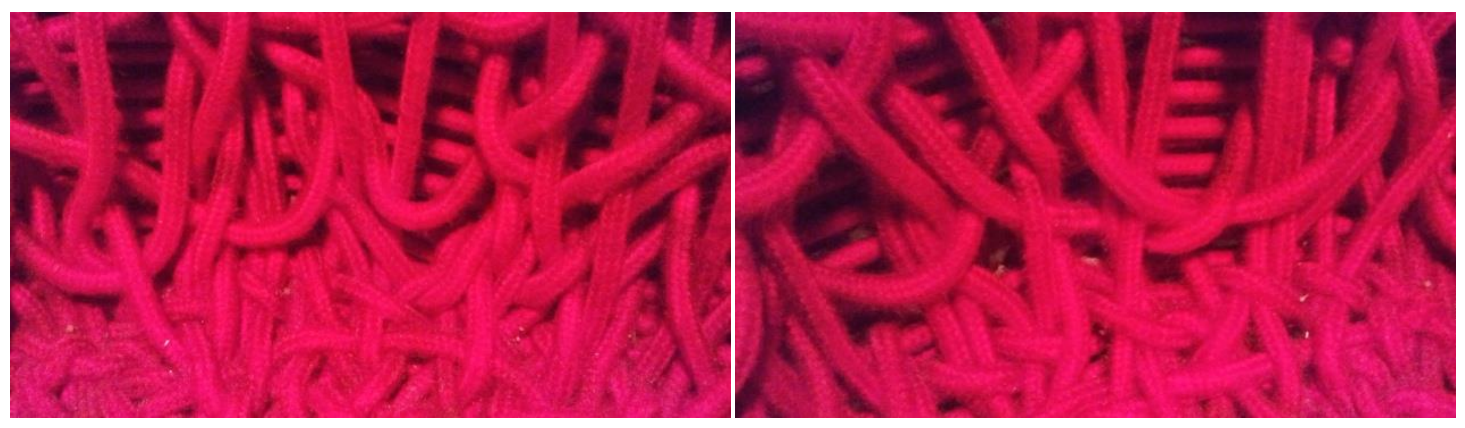

Figura 97 - Detalhe da configuração dos laços e nós da Cadeira Vermelha

Visualmente, há uma desconexão entre a expectativa que o móvel gera e a experiência física que ele proporciona. $\mathrm{O}$ emaranhado de cordas e a forma de concha sugerem conforto, aconchego e relaxamento, no entanto, a rigidez e textura muito pronunciada das cordas, aliada às dimensões da cadeira, como a relação entre largura do assento de $86 \mathrm{~cm}$, profundidade de $58 \mathrm{~cm}$ e altura de $77 \mathrm{~cm}$, impedem uma posição de relaxamento completo, pois são dimensões consideradas impróprias para tal. A textura proporcionada pelo entrelaçamento das cordas torna-se desconfortável após alguns minutos e as dimensões são mais comuns em modelos de poltronas ou cadeiras utilizadas em áreas comerciais, que exigem uma postura mais formal de quem senta. Quanto a este ponto em particular, isso fica mais claro quando comparamos as dimensões da Cadeira Vermelha com um excelente exemplar de poltrona para relaxar, a Poltrona Mole, que possui menos de $75 \mathrm{~cm}$ de altura do assento e $100 \mathrm{~cm}$ de profundidade, ou seja, o dobro da dimensão da Cadeira Vermelha.

Assim, a Cadeira Vermelha é uma cadeira com forma de poltrona, pois tem como características a integração dos braços, com assento e encosto, mas com dimensões de cadeira. 
Podemos dizer que a Cadeira Vermelha apresenta-se mais como um objeto de contemplação do que de uso prático. Como assento, trata-se de um móvel que não surpreende pelo conforto. Como os próprios designers afirmam "O material veio primeiro, depois a forma ou a função", (ALFRED, 2010, p. 128).

A Cadeira Vermelha, em função dos seus materiais e proposta de projeto, é um móvel próprio para áreas internas. Dada a sua presença, o seu valor e as suas características ergonômicas, costuma ser alocada em áreas de maior visibilidade e convívio social, como salas de estar, recepção e hall de entrada como ilustrado na figura 95. Trata-se de um móvel para ser admirado, observado, contemplado, e, eventualmente, utilizado como assento por períodos breves, dadas as suas características ergonômicas.

Esse móvel molda-se, literalmente, ao contexto e forma como é utilizado. As cordas, apesar de especiais, sofrem com ação da gravidade e do uso, perdendo tensão nas áreas verticais. Essa característica não chega a comprometer a estrutura ou estética do produto, mas estabelece unicidade a cada peça.

Deve-se destacar que a permanência da Cadeira Vermelha foi muito alterada após a sua produção pela empresa Edra. As primeiras 5 peças fabricadas no Estúdio Campanas, em 1993, não foram projetadas pensando-se numa permanência prolongada, assim como vários outros produtos dos dois designers. Um exemplo disso está no processo de descoloração e desgaste das cordas das primeiras cadeiras, que eram feitas com cordas comuns, de algodão tingido de vermelho pelos próprios Campana. Após 10 anos, alguns modelos passaram do vermelho para o "vermelho desbotado".

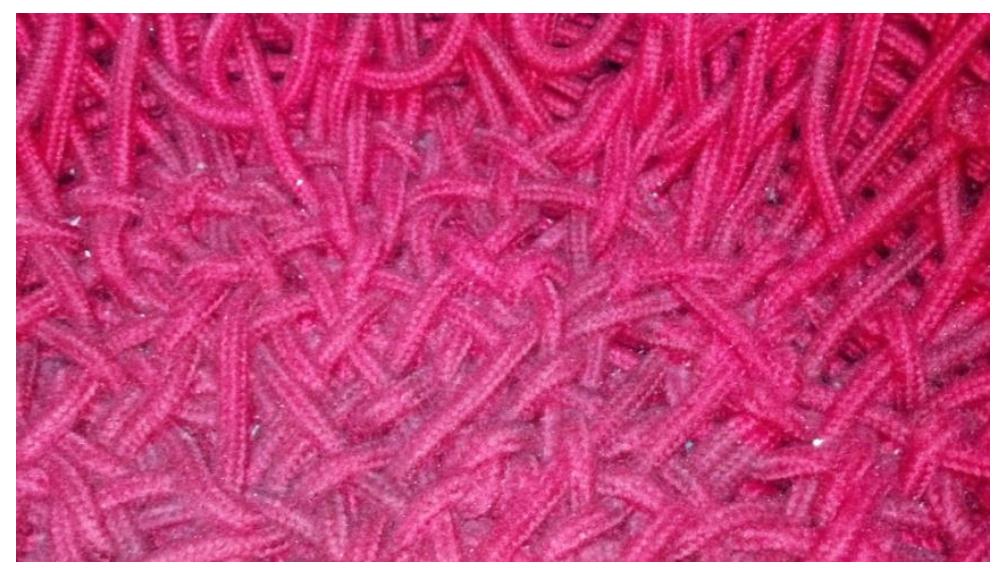

Figura 98 - Efeito do desgaste e da descoloração das cordas nos primeiros modelos 
Ao adquirir os direitos de produção, a Edra passou a utilizar controles de qualidade e assistência ao consumidor, mais eficientes e rigorosos. Problemas como perda de cor já não são comentados e, de 1998 a 2014, não houve queixas quanto à durabilidade das cadeiras. Ainda assim, dado o uso de materiais sintéticos, como cordas com núcleo de acrílico, não é possível prever se essas cadeiras terão a mesma durabilidade e permanência esperadas dos materiais ditos mais "nobres" como a madeira e o couro, tão comumente utilizados na produção moveleira brasileira dos móveis de Sergio Rodrigues e Cláudia Moreira Salles.

\section{c) Percepção}

A Cadeira Vermelha apresenta uma experiência e interação principalmente pelo impacto visual que causa. O emaranhado suspenso de cordas vermelhas surpreende pela complexidade de texturas e simplicidade formal: algo que remete à ideia de ninho, de aconchego, de lar. Outras cadeiras dos Irmãos Campana também se utilizam de cordas, como as cadeiras Verde e Azul, que fazem parte da linha de produtos sob o conceito "Materiais Deslocados", segundo Alfred (2010). No entanto, nenhuma das duas é tão convidativa a se sentar como a Cadeira Vermelha.
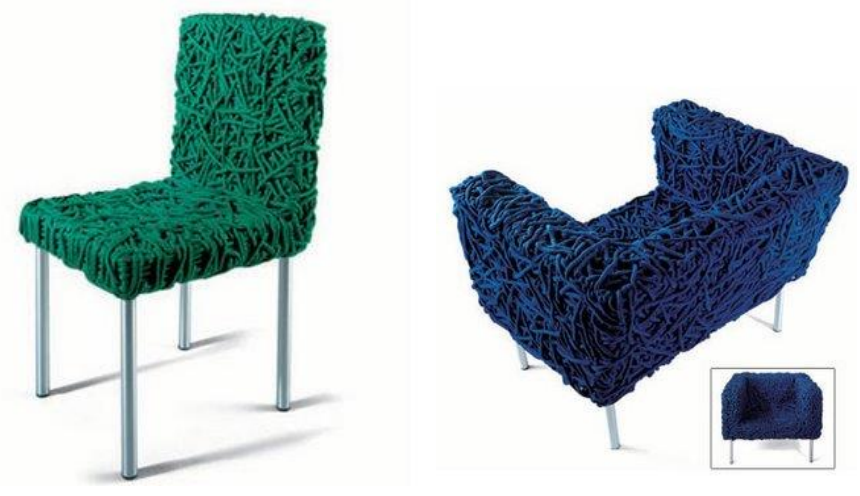

Figura 99 - Cadeiras Verde e Azul (1993)

O uso das cordas em um contexto inesperado, como estofado, remete ao improviso, humor e à experimentação, que são características comuns a várias obras dos Irmãos Campana. Apesar do preço elevado, a Cadeira Vermelha partiu do uso da corda de algodão, um produto popular e encontrado facilmente em qualquer comércio. Essa 
característica torna a cadeira estranhamente familiar, pois o recurso principal, no caso a corda, é comum a todos, mas a sua aplicação é inédita e criativa.

Outros dois pontos que se destacam na cadeira e fazem parte da poética dos designers são a acumulação e a repetição de um mesmo elemento ao ponto de se obter uma forma e textura únicas. Apesar de haver um método definido para entrelaçar a corda, cada peça apresenta uma textura diferente. Isso porque a complexidade do trançado, que leva um dia e meio para ser executado, impede que os gestos para se emaranhar a corda do assento/encosto se repitam exatamente em outros modelos. $\mathrm{O}$ resultado são produtos semelhantes, mas nunca iguais. A repetição sem a padronização, ou como diria John Ruskin (1989), a variedade, não a monotonia.
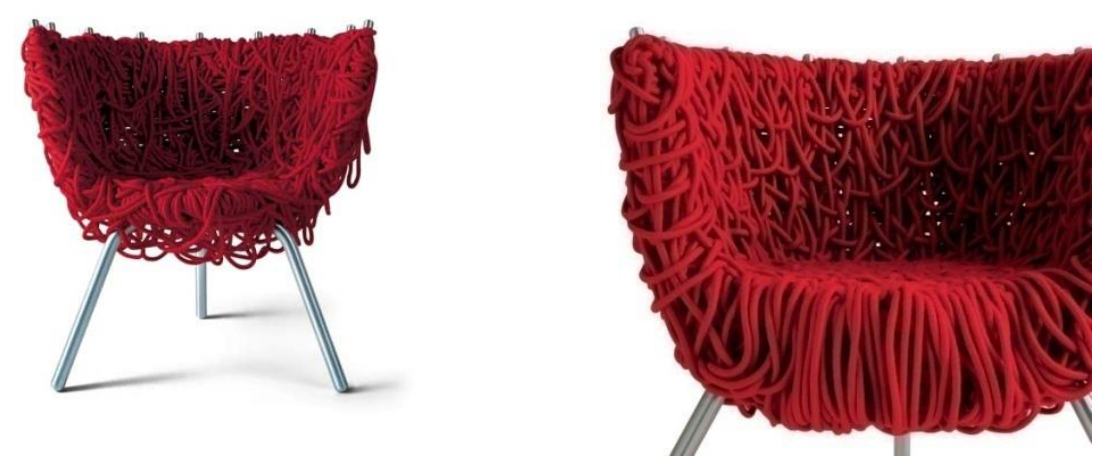

Figura 100 - Diferentes efeitos da variação do trançado da corda nos modelos produzidos, Irmãos Campana, 1993; Edra, 1998

Outro ponto de destaque é o aspecto ao mesmo tempo regional e globalizado da Cadeira Vermelha. O colorido da cadeira, o improviso e a criatividade no uso de materiais comuns e baratos são tidos como características diferenciais do design dos Irmãos Campana e do design brasileiro.

Conectando seus produtos à verdadeira natureza do Brasil, os irmãos Campana nos dão um novo modo de explorar a modernidade, caracterizado pela inovação com irreverência, tecnologia aliada às tradições artesanais e materiais sofisticados casados com outros básicos e crus. (MOROZZI apud CAMPANA, 2003, p. 306).

Maria Helena Estrada, jornalista e crítica de design, afirma que o trabalho dos irmãos Campana se mostra incontaminado, pois, com o olhar livre de preconceitos, o intuitivo e o espontâneo se apresentam de forma presente (CAMPANA et al., 2003). 
Já para Paola Antonelli, ${ }^{50}$ os designers têm a capacidade de criar objetos que falam línguas diferentes, pois "brincam” com diferentes materiais transcodificando suas estruturas físicas e visuais: “[...] pegam varetas de alumínio e as tratam como bambu, entrelaçando-as [...]" (CAMPANA et al., 2003, p. 319).

Essa é uma característica que Norman (2008) classifica no design comportamental como inovação, uma forma completamente nova de fazer alguma coisa. Ao usar materiais que, em princípio, têm características e leituras prefixadas, os designers apelam para uma atitude de descontextualização das "verdades imanentes" para colocá-las em choque com a realidade. Será por um processo de descobrimento ou desvelamento que o indivíduo experienciará esse novo contexto material.

O fato é que o trabalho dos Irmãos Campana, aqui representado pela Cadeira Vermelha, demonstra um processo que não parte de procedimentos projetuais e conceituais próprios daqueles das prerrogativas do design tradicionalmente difundido no Brasil, em que se adotava o dogma funcionalista, mas de um natural espírito de observação: subjetivo, criativo e gestual.

No trabalho dos Campana a figura do autor-pessoa é extremamente mais proeminente do que a do autor-criador (BAKTHIN,1992). Como os próprios designers dizem, partem do material, do emocional, do gesto e das suas subjetividades.

O olhar atento às coisas, o fazer gestual, o deslocamento no uso dos materiais e os procedimentos de experimentação são tomados como prática de criação. Usando de uma linguagem com humor e ironia em muitos dos seus trabalhos, os designers chegam muito próximos de um nonsense.

Seus trabalhos recorrem a processos de descontextualização, quando imagens familiares a nós mudam de sentido de um campo a outro. São objetos que brincam e jogam com nossas referências e nossas expectativas. A emoção sugerida ao indivíduo espectador é uma mescla de surpresa e de estranhamento. Em Freud (1969), o estranhamento é algo já conhecido que está enclausurado no inconsciente, e quando vem à tona causa emoção de medo, terror, estranheza.

É nesse aparente descompasso ou desvio, nesse choque do tempo passado e do tempo presente, no choque das funções e dos valores que se instaura o trabalho dos Irmãos Campana.

\footnotetext{
${ }^{50}$ Atuou com professora de design na UCLA, foi editora de design da Revista Abitare e curadora de arquitetura e design do MoMA, N. York.
} 
Na Cadeira Vermelha não foi diferente. O uso de metros de corda, a nós um material tão familiar e comum, utilizado para amarrar ou unir um objeto ao outro, vira material para estofado. Material popular, industrial, de fácil aquisição e consumo rápido.

Ao converterem a corda em matéria-prima, material de natureza popular e de traços marcadamente industriais, e em princípio, não reconhecida como material "artístico", os designers se apropriam e produzem aquilo que exprime o espírito do mundo atual, usando alguns materiais de uso corrente, envolvendo a arte no contexto cotidiano.

O material foi destituído de sua função inicial e transcodificado para que as impressões e as ideias dos designers assinalassem a efemeridade daquilo que é oferecido pela era industrial. Utilizam os materiais sem preconceitos, materiais que povoam o nosso cotidiano, povoando assim os nossos sentidos e sentimentos.

A Cadeira Vermelha é um "objeto emocional" de grande força expressiva, não repete nenhuma "fórmula", tampouco quer exprimir uma "verdade". É uma fotografia do entorno, da cultura, mas ao mesmo tempo, luta contra o igual, contra a massificação.

Sua forma de concha (ou ferradura) nos remete a um ninho, construído aleatoriamente de pequenas partes que formam um todo. Esse todo, constituído por uma trama de laços e nós, trançados e emaranhados, constitui uma superfície irregular, que, como dito anteriormente, nos causa emoções de surpresa, mas ao mesmo tempo, estranhamento. Ou seremos massageados, ou seremos incomodados. O fato é que, de uma maneira ou de outra, seremos marcados.

Esse ninho é fluido, não delimitado totalmente, pois apresenta "fendas", buracos dados pelo emaranhado das cordas, que, somando-se umas às outras, dão um todo não contínuo. São os vazios entre os nós que formam o espaço: de nó em nó, de vazio em vazio, o volume vai sendo delimitado.

A textura desses laços e nós gera uma trama com aparência de caos em um primeiro momento, mas ao analisarmos ou contemplarmos mais atentamente vemos que as cordas possuem um movimento rítmico de entrelaçamento. Formam "arabescos" que asseguram a constituição e irradiação do volume.

Como dito anteriormente, quando a empresa Edra assumiu a produção da Vermelha, foi sistematizado todo um processo para a fabricação da cadeira. Assim, é nítido o controle do processo do "tecer" da corda que foi instituído (figura 100). O caos 
foi substituído pela aleatoriedade, pelo ritmo e movimento dos nós do encosto e assento, e pela verticalidade e monotonia das cordas que caem desse mesmo assento.

O conceito de ninho pode seguir dois caminhos, que provocam um sentimento positivo, outro negativo. O positivo nos remete ao aconchego, aos conceitos de lar, privacidade e segurança, trabalhados no capítulo 3. Um ninho para o corpo, um lar para o corpo. O outro se refere também ao ninho, contudo um ninho para a sujeira, causandonos até algum tipo de sentimento de repulsa. Como demonstrado na figura 97, há um desgaste e acúmulo de sujeira por entre a trama aberta das cordas.

Positiva ou negativa, a imagem que nos surge é aquela que nos remete ao ninho enquanto lar.

Um outro olhar nos faz necessário. A trama das cordas, o formato de ninho e a cor vermelha viva nos levam à imagem de um útero, lar primeiro, com suas veias que nos rodeiam, com seu sangue que dá vida.

O uso do material não sintético das cordas (algodão) é propício a armazenar outras impressões, como o odor: os cheiros e perfumes do ambiente e daqueles que nela se sentam.

Partindo para uma análise da conjunção da estrutura metálica com a trama da corda, notamos que o processo de entrelaçamento alcança certa (pequena) distância entre a superfície final dos laços e o topo das hastes do encosto. As ponteiras de alumínio da estrutura das hastes ficam aparentes (figura 94). Esse pequeno acabamento nos remete à ideia que tenta afirmar uma imagem de que há uma estrutura que reforça ou sustenta aquela superfície de composição caótica ou aleatória que o entrelaçamento da corda nos remete. Plasticamente, o contraste entre as cores, prata (fria) e vermelha (quente), e entre os materiais, corda (material natural) e o alumínio (metal) dentro de espaços iguais e predeterminados, coloca-nos um ritmo e repetição de elementos que aguçam o olhar: pontos brilhantes fixos dentro do caos, organização dentro do caos, o industrial dentro do artesanal.

Outra característica da conjunção entre estrutura metálica e trama, é acerca do processo de entrelaçamento da corda (nota-se que a corda é contínua e não interrompida) executado na estrutura metálica como se esta fosse um verdadeiro tear.

Primeiramente, a corda é inserida nos tubos como uma trama de uma perfeita cestaria. Em seguida são inseridos os pontos, os nós, os laços, os movimentos de cruzar e entrecruzar a corda. 
O gesto do artesão (figura 96) é efetuado como trabalho manual, que exige uma distinção da habilidade de quem executa, por maior que seja o controle da execução. É como o bordar, o crochetar ou o tricotar: há o ponto estreito ou frouxo, o ponto aberto ou fechado. Existe um processo de controle que vem da técnica apurada, mas também a espontaneidade, que vem do gesto.

Assim, a qualidade das técnicas artesanais de tecelagem proeminentes da Cadeira Vermelha é uma de suas principais características que incidem sobre o valor simbólico e está diretamente relacionada à tradição histórica que este ofício instaurou no Brasil.

E é assim que é a Vermelha: feita de laços e abraços.

\subsection{Banco Siri}

O Banco Siri é um autêntico móvel que representa a força da expressividade contida na beleza "imperfeita" dos materiais naturais, em conjunção com a geometria e as técnicas rigorosas de fabricação e acabamento.

a) Descrição dos elementos

O Banco Siri possui 2 metros de largura por 1 metro de profundidade e 80 centímetros de altura. Pode ser percebido por uma grande almofada suspensa por 4 pés em madeira e por dois encostos maciços posicionados de forma simétrica.
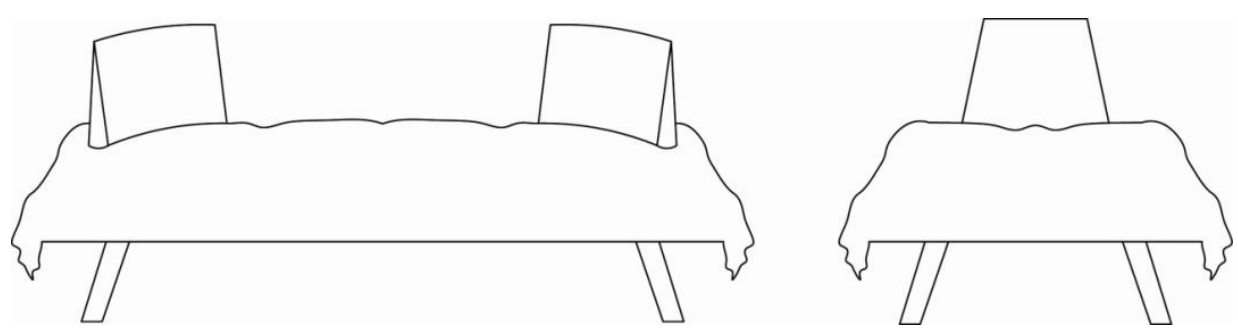

Figura 101 - Dimensões do Banco Siri, (L) 200cm x (P) $100 \mathrm{~cm}$ x (A) $80 \mathrm{~cm}$

Os pés do banco têm forma de prisma inclinado de base quadrada, dispostos de forma simétrica, dois a dois, estabelecendo um grande vão no meio do banco. 
A base rígida em madeira encontra-se escondida sob a almofada do banco, que cobre toda a extensão do móvel.

Os encostos são pivotantes, ou seja, giram em torno de um eixo.

A aparência dos encostos é sólida, côncava, com uma base espessa e extremidades mais finas. Esta diferença de espessura proporciona a inclinação precisa e ergonômica para o conforto da peça.

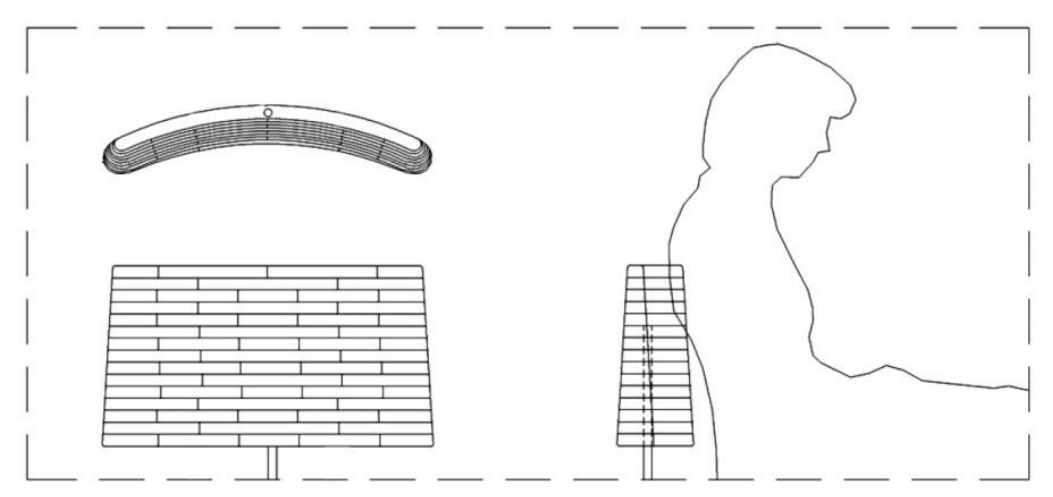

Figura 102 - Desenho esquemático do encosto do Banco Siri (adaptado pela autora)

O Banco Siri é composto basicamente por 4 elementos: 4 pés, 1 base semirrígida e estofada, uma grande almofada e 2 encostos.

Os 4 pés são de madeira maciça, fabricados nas opções de madeiras Freijó, Sucupira e Imbuia, ${ }^{51}$ cabendo ao cliente escolher o tipo de madeira. Os pés são fixados a uma base semirrígida, estofada, que recebe a almofada e os dois encostos.

O elemento de estruturação do Banco Siri é uma base retangular, de madeira, com percintas elásticas, toda revestida por uma fina camada de espuma e tecido. Essa mesma base possui apoio para os dois eixos pivotantes dos encostos e os quatro pés que sustentam o banco.

A almofada possui uma estrutura semelhante a um travesseiro, ou seja, existe um recheio de espuma ou pluma de ganso e uma capa externa, que pode ser obtida em diversos tecidos e cores, como linho cru, algodão e couro sintético. Essa almofada recebe 10 capitonês em toda a sua face superior. Trata-se de um adorno comum em estofados obtido por laços largos de fitas de algodão (cadarços) amarrados em ambas as extremidades que deixam algumas áreas mais justas que outras, formando assim os

\footnotetext{
${ }^{51}$ Disponível em:<www.claudiamoreirasalles.com $>$.
} 
"gomos" da almofada. A almofada possui dois ilhoses por onde passam os dois tubos de sustentação dos encostos.

Os encostos são feitos com sarrafos de madeira maciça, com espessuras entre $25 \mathrm{~mm}$ e $30 \mathrm{~mm}$ e comprimento variável. São ripas de resíduos de madeira reaproveitada da Etel Marcenaria (fabricante do banco), coladas e usinadas, formando um único elemento sólido, nas mesmas opções de madeira e acabamento oferecidas para os pés do banco. A parte de baixo do encosto recebe uma base metálica, que por sua vez recebe um eixo pivotante que permite que o encosto gire. Tanto o encosto quanto a almofada podem ser retirados para manutenção e lavagem do móvel.
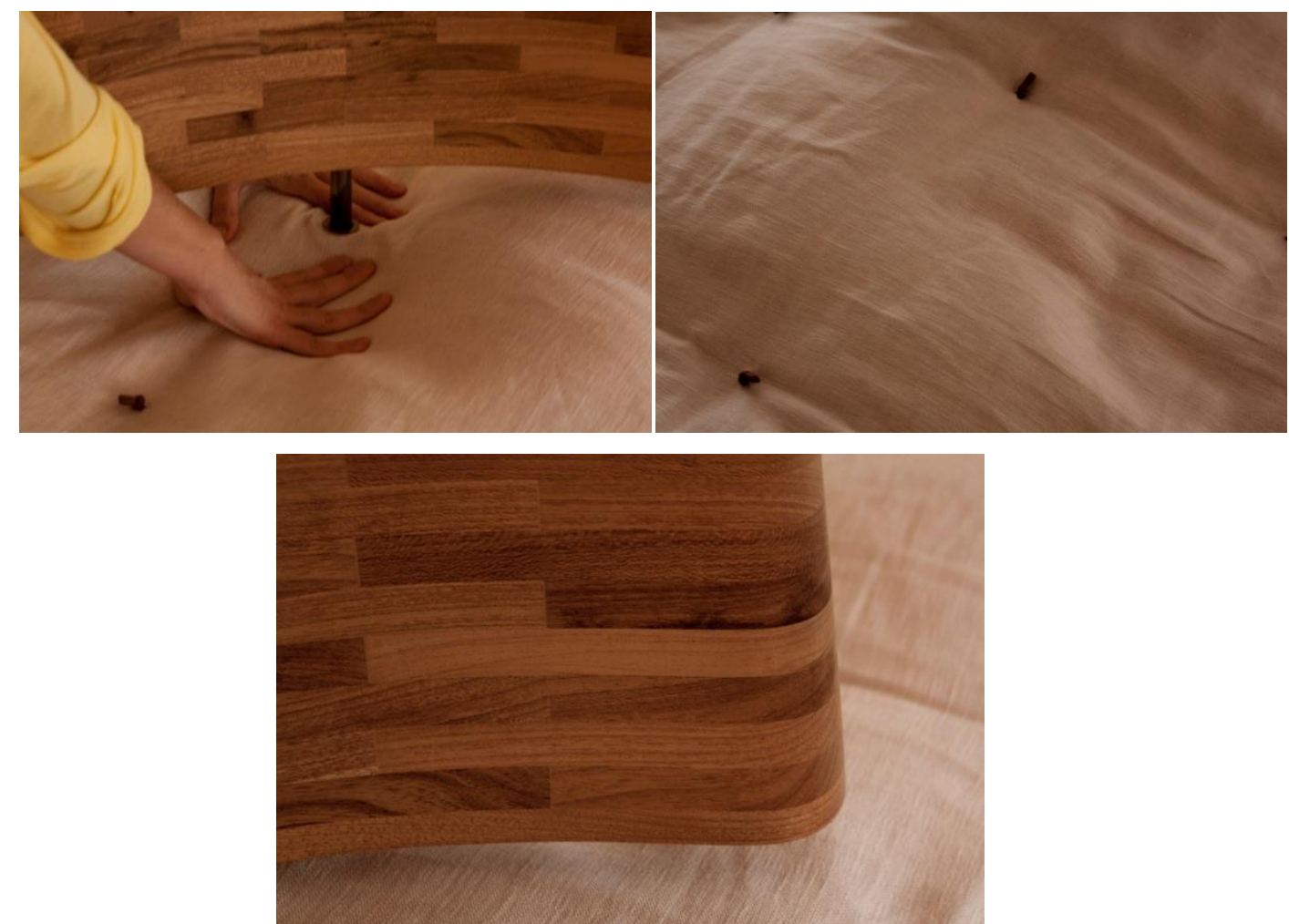

Figura 103 - Detalhes do Banco Siri - eixo pivotante; uso do capitonê; encosto fabricado com refugo de ripas de madeira

O processo de produção do Banco Siri é bastante manual. As peças em madeira são produzidas utilizando-se máquinas tradicionais como desengrosso, plainas, serras circulares e prensas hidráulicas. As ripas de madeira do encosto são coladas, prensadas e moldadas a partir de uma curvatura específica, especialmente definida para dar conforto e dispensar o uso de estofamento. 


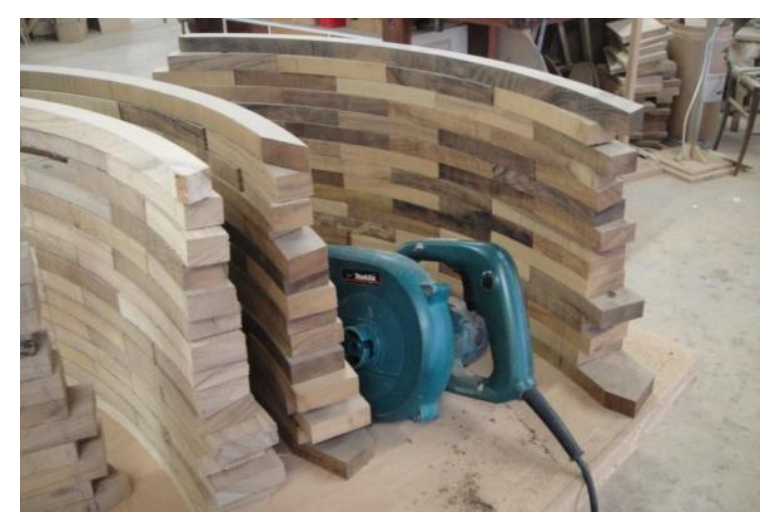

Figura 104 - Esquema de produção dos encostos com reaproveitamento de madeiras e curvamento das ripas

$\mathrm{O}$ assento é um requadro de madeira pregada e colada que recebe uma trama de percintas e uma fina camada de espuma, que é colada sobre a madeira e apoiada sobre as percintas. O tecido é grampeado pela parte de baixo do banco, permanecendo esticado em toda extensão.

O estofado também é feito manualmente, como um travesseiro: uma capa interna preenchida de espuma ou pluma de ganso, e uma capa externa, que varia entre o algodão, couro sintético e outros tecidos ${ }^{52}$. Essa manualidade fica exposta na aplicação dos nós dos capitonês, na costura da saia e no acabamento da almofada.

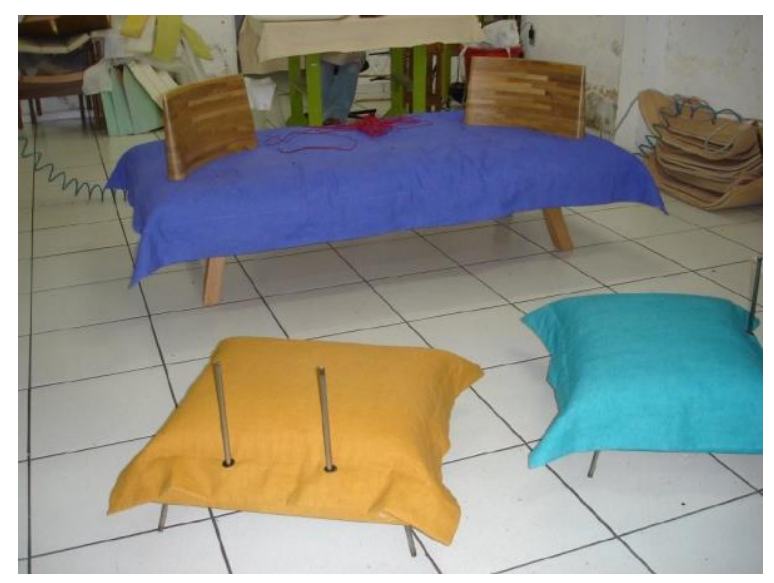

Figura 105 - Esquema de montagem e cores do estofado

52 Segundo a empresa Armazém da Decoração, representante da marca Claudia Moreira Salles, em Goiânia, 2014. 
b) Contexto(s) de uso(s)

O Banco Siri foi projetado a partir de uma encomenda para a arquiteta Silvia Almeida Braga, em 2008. A cliente precisava de um banco que dividisse dois ambientes, e que pudesse funcionar nas duas situações. Para tanto, a cliente sugeriu que os encostos dos bancos fossem móveis, ou seja, que pudessem girar e servir aos dois ambientes, como um elemento de união entre dois espaços.

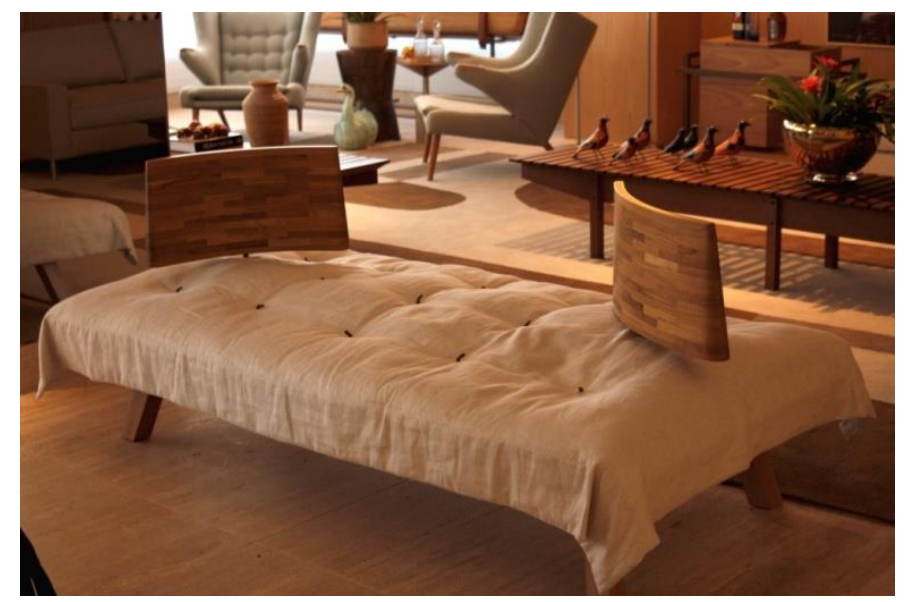

Figura 106 - Banco Siri utilizado como divisor e integrador de ambientes

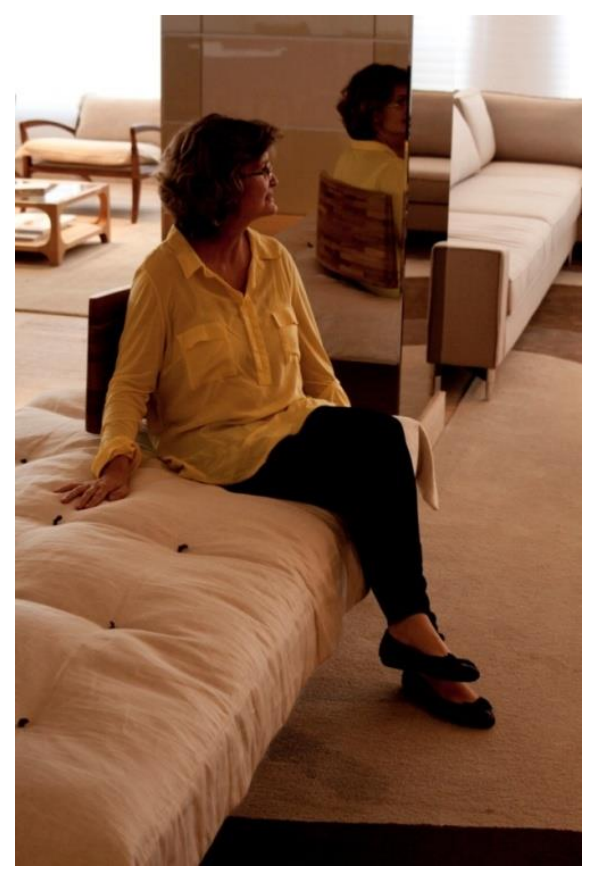

Figura 107 - Banco Siri utilizado como divisor de ambientes 
Dado o briefing bem dirigido, coube à designer Claudia Moreira Salles dar forma a essa demanda, assumindo de modo categórico a posição de designer-criador. Claudia estava entusiasmada por usar as ripas de madeira que sobravam e eram guardadas na fábrica da Etel Marcenaria e resolveu experimentá-las. Após testar várias dimensões quanto à profundidade e curvatura do encosto em relação ao assento, a designer chegou a um dimensionamento que permite ao usuário se acomodar com muito conforto em qualquer posição. ${ }^{53}$

O Banco Siri pode ser utilizado de diversas formas, sendo uma peça extremamente versátil. Dependendo da posição do encosto, o banco pode virar uma namoradeira, uma chaise longue ou até mesmo uma cama, tamanho o dimensionamento da peça.

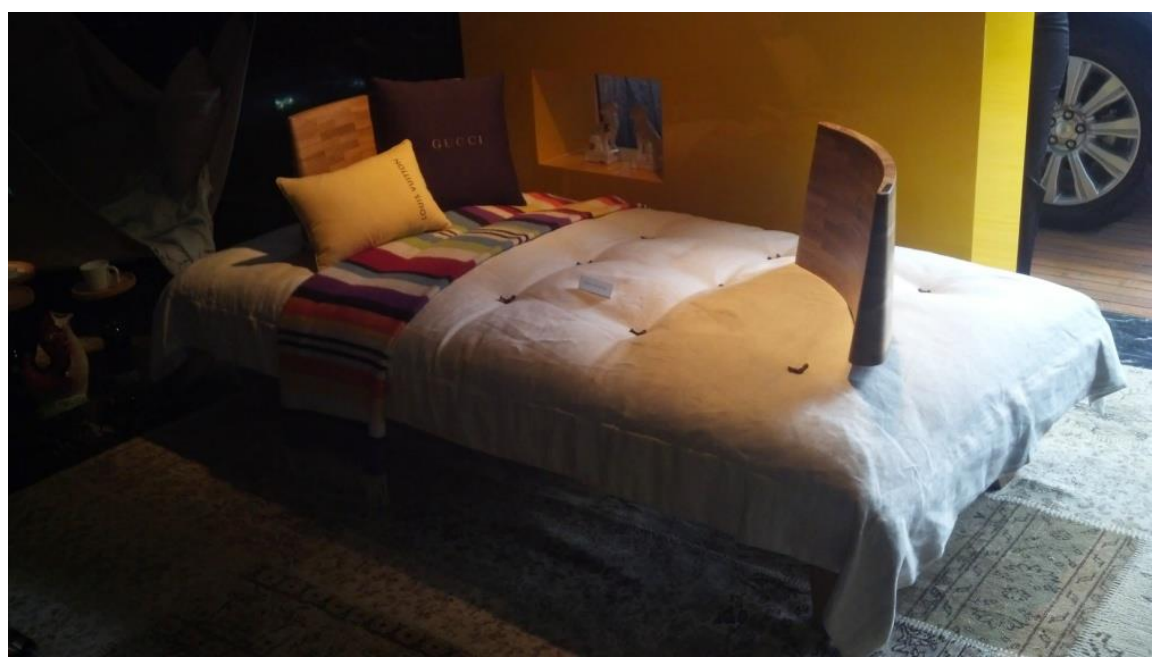

Figura 108 - Utilização do Banco Siri - de avantajado dimensionamento, o móvel proporciona posições diversas de descanso

A posição dos encostos também permite diversos níveis de interação dos usuários. As pessoas podem se sentar de frente umas para as outras, de costas e de lado, ou até mesmo se deitar.

53 Entrevista de Claudia Moreira Salles à autora em 2013. 

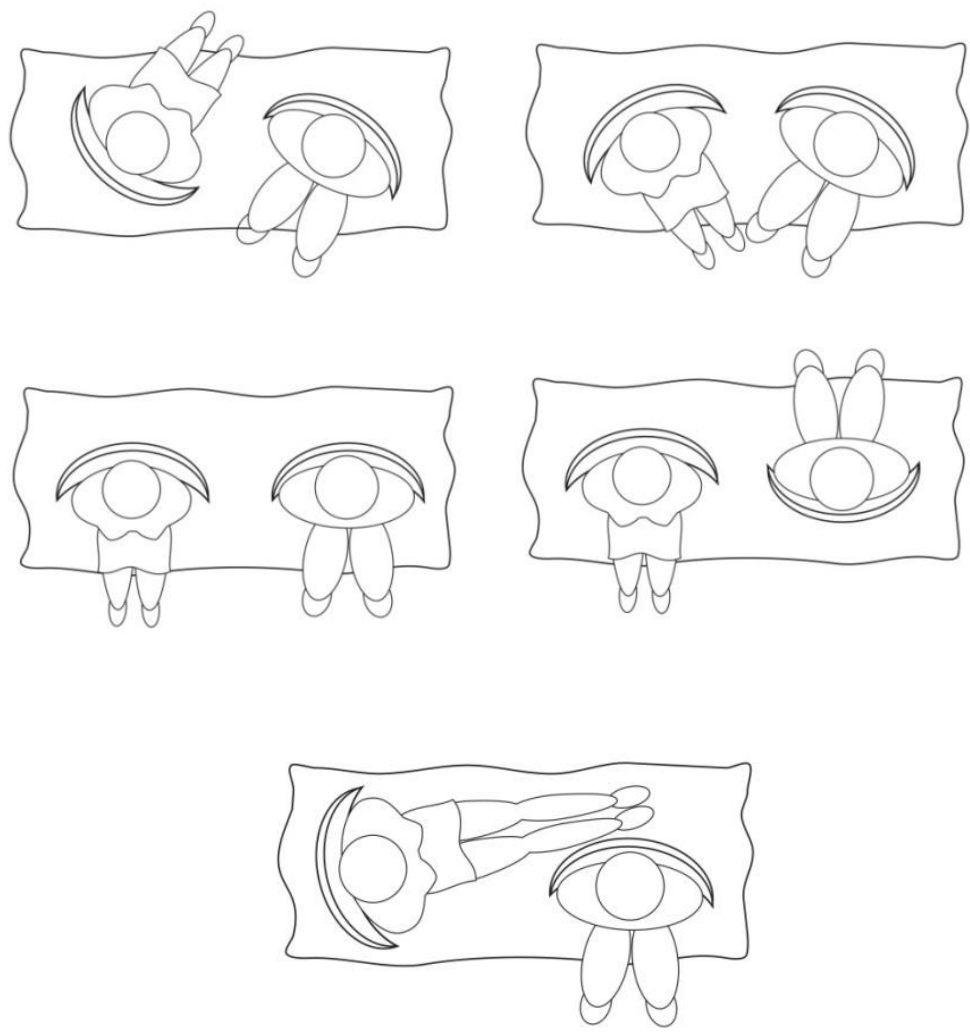

Figura 209 - Utilização do Banco Siri - interação de usuários e ambientes proporcionada pelo uso dos encostos giratórios

O Banco Siri é uma peça para ser utilizada em áreas internas, como salas de estar e salas de espera. Como já mencionado, foi projetado para dividir e ao mesmo tempo integrar dois ambientes, no caso salas de estar e sala de jantar, ou salas de estar e hall de entrada. Dado o seu porte dimensional e a sua proposta de uso também coletivo, não se trata de um móvel para espaços muito privados, como quartos, por exemplo. Seja sozinho ou acompanhado, o indivíduo pode se sentar com conforto no banco de várias formas, dependendo do contexto que a situação exija, pois o móvel permite que o usuário assuma tanto uma postura formal, ereta, quanto informal, relaxada.

\section{A Linha SIRI}

A Linha Siri é composta por duas peças: Banco e Poltrona Siri. Segundo Claudia Moreira Salles, o projeto foi iniciado pelo desenvolvimento do encosto para o banco, pois, como já dito anteriormente, havia o desejo de reaproveitar os refugos de madeiras da Etel Marcenaria. Depois de resolvidas as questões de conforto e dimensões do encosto, a designer partiu para o estudo da almofada/assento. 
O projeto do banco foi tão bem aceito que a designer decidiu desenvolver uma poltrona com os mesmos princípios formais, conceituais e construtivos para formar uma linha de móveis.

Contudo, a Poltrona Siri não possui o encosto pivotante, mas fixo. Como não tem a proposta de dividir ambientes e apenas uma superfície de assento, não seria necessária a função de girar sobre o mesmo eixo.

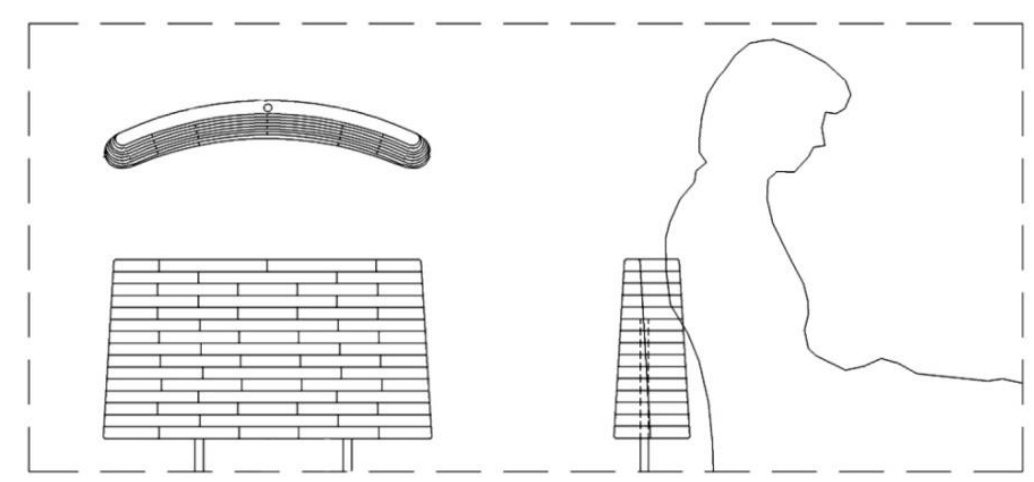

Figura 110 - Desenho esquemático do encosto da Poltrona Siri com dois eixos fixos
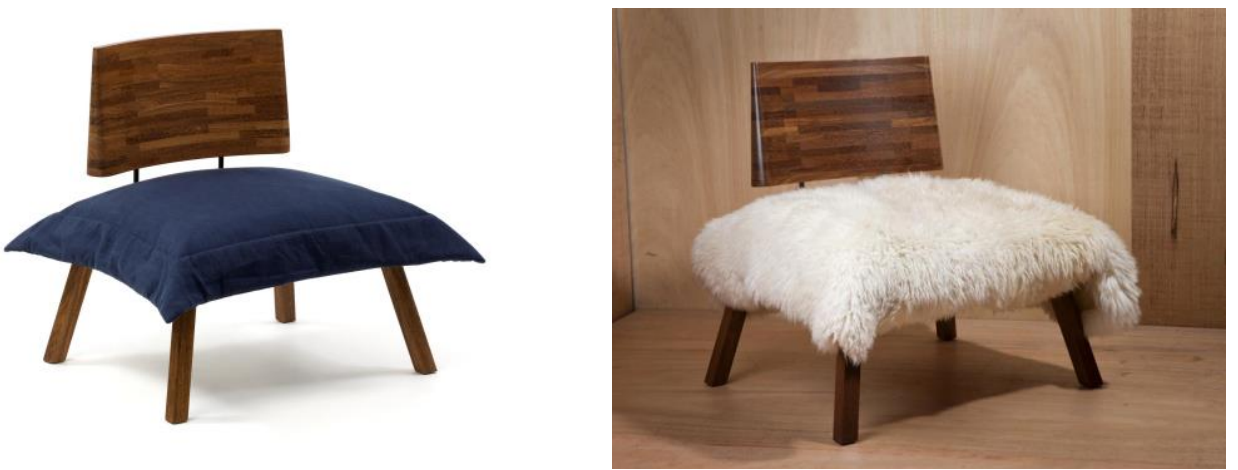

Figura 111 - Poltrona Siri com variação de acabamento do estofado/assento

Segundo Claudia Moreira Salles, houve um grande encantamento por ela e pela equipe em relação ao resultado final obtido pelo encosto da Linha Siri. Isto quer dizer: questões de conforto e ergonomia, os métodos de produção, a utilização dos refugos de madeira, mas principalmente o efeito visual que a forma $\mathrm{e} o$ acabamento proporcionaram. 
Por essas razões, a designer desenvolveu no ano de 2012 a Poltrona Serena, e utilizou os mesmos princípios construtivos da Linha Siri para o encosto e assento, contudo com as dimensões um pouco alteradas.

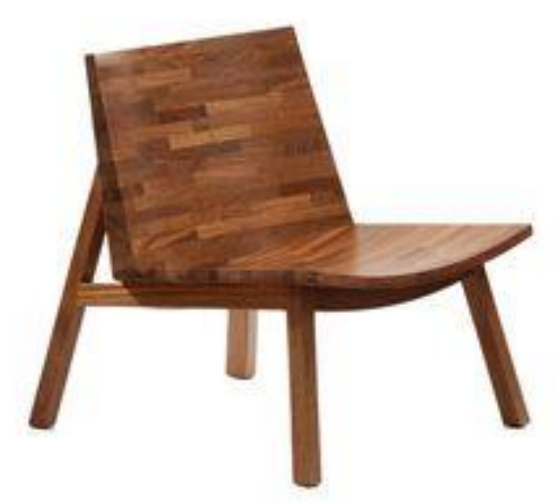

Figura 112 - Poltrona Serena (2012) com assento e encosto em madeiras de refugo - Cedro, Feijó e Sucupira

\section{c) Percepção}

O Banco Siri propõe uma interação como pouco visto em móveis até o momento. A almofada que o envolve é extremamente macia e os encostos, apesar de parecerem pouco convidativos à primeira vista, são muito confortáveis e permitem uma experiência de uso bastante interativa. Essa interação é muito rica, pois deixa o usuário à vontade para se sentar da maneira que quiser, atuando de forma livre tanto com o objeto quanto com as outras pessoas que o usufruem.

Apesar da imagem estática que a peça passa ao ser observada, o banco permite uma interação que não impõe barreiras ou formas de usar, pelo contrário, proporciona modificações de usos variados e surpreendentes aos usuários.

O Banco Siri é uma peça projetada para durar muito tempo. As madeiras utilizadas são consideradas nobres, com refinado acabamento artesanal e resistente ao uso e ao tempo. A almofada pode ser retirada para higienização ou para ser trocada por outro tipo de acabamento. O móvel como um todo tem um aspecto muito sólido, com materiais, ferragens e acabamento de alta qualidade. Se fisicamente o móvel foi projetado para durar, visualmente, apesar de incomum, é sóbrio pela escolha dos materiais e formas gerais. Trata-se de um móvel cuja forma também possui uma 
preocupação com a temporalidade, não recorrendo a modismos ou conceitos que possam se desgastar com o tempo.

De 2 metros de largura por 1 metro de profundidade e 80 centímetros de altura, e uma grande almofada suspensa por 4 pés de madeira e por dois encostos maciços posicionados de forma simétrica, o banco Siri provoca um contraste interessante entre superfícies solidas e macias, tecido e madeira, elementos verticais e horizontais.

A forma geral da peça, com os 4 pés e os dois encostos que brotam para fora das almofadas, lembra um siri, em que os encostos seriam os olhos e a almofada a carapaça. Vale ressaltar que essa forma não partiu de uma referência ao crustáceo, sendo o nome dado em homenagem posterior à composição do banco.

A disposição simétrica dos pés de base quadrada, dispostos dois a dois, e o rigor geométrico e construtivo encontrado na estrutura da base rígida em madeira que se encontra escondida sob a almofada do banco, estabelecem um grande vão no meio do banco e podem ser comparados aos "pilotis" 54 tão presentes na arquitetura modernista, que serviam, além de pilares estruturais, como integradores entre o espaço urbano externo e o espaço interno dos empreendimentos. É a ligação entre homem (casa) e natureza (espaço externo). Aqui, enquanto banco, é a ligação entre os dois ambientes.

A almofada tem uma aparência macia que é reforçada pelos "gomos" formados por figuras geométricas (quadrado) advindas do uso dos capitonês, que dão essa sensação de maciez: uma nuvem assentada sobre o banco. A almofada também apresenta uma espécie de saiote que reforça uma ideia de leveza e feminilidade.

Outra interpretação que podemos dar para o seu estofamento é compará-lo não a uma almofada, mas a uma cama: conjunto de colchão, colcha, lençol. Seu aspecto rústico dado pelo uso do algodão cru; dos pontos quase que soltos dos capitonês que se utilizam de cadarços com nós, substituindo os tradicionais botões empregados desde a era vitoriana; a aparência de tecido usado e amassado que o algodão proporciona; e o "saiote" que contorna todo o banco, remetem-nos ao colchão de palha, ao colchão confeccionado pelas nossas avós, à colcha mal estendida na cama quando as pessoas se deitaram nela. Da colcha ou lençol estendidos na cama, temos o tecido que se move e molda-se no corpo e pelo corpo. De superfície irregular, também macia, aparenta a não

54 Tecnicamente, pilotis são as colunas ou pilares estruturais que sustentam uma construção, deixando livre o pavimento térreo. A palavra pilotis, de origem francesa, pode se referir tanto ao pilarem si, quanto ao sistema como um todo. Disponível em:<http://www.colegiodearquitetos.com.br/dicionario/2009/02/oque-e-pilotis/>. Acesso em: jan. 2015. 
regularidade dos colchões e superfícies produzidos manualmente. Não é ortopédico, mas anatômico.

O conceito de cama, marcado principalmente pelo "saiote" e suas dimensões, resgata o lugar de encontro íntimo em contraposição à namoradeira ou ao banco, peças que têm apenas como latência essa intimidade, sendo concedida somente a troca entre olhares, sem contato físico. Por isso, o Banco Siri, por meio dos encostos giratórios e suas possibilidades de uso é uma namoradeira contemporânea, pois possibilita e altera o conceito de namorar, permitindo que haja uma mobilidade dos sujeitos atuantes e em ação. Cama versus banco, namorar íntimo versus namorar latente.

Nesse sentido, o banco ativa as expectativas do usuário e as possibilidades de escolha, pois há interação dos indivíduos entre si e deles com o ambiente.

Mas... uma cama na sala? São as propostas contemporâneas, objetos singulares e interativos. Quem recebe uma pessoa em seu quarto, em sua cama, torna a relação mais íntima: objetos que tornam a vida privada, mais privada. Objetos que trazem para perto, trazem para a intimidade, levam para a cama. E existe objeto mais íntimo que a nossa cama?

O que desconfigura o conceito formal clássico de cama são os encostos pivotantes colocados nas duas extremidades do banco, que se apresentam como dois blocos sobre a "cama". Mas isso é o que instiga e atiça a curiosidade, pois o estranhamento causado pela divisão formal entre o elemento "cama" e os elementos "encosto" vai diminuindo e será na experimentação e na experiência do uso que acontecerão as descobertas e o entendimento do que fala o objeto. São os olhos do Siri, figura alegórica. São os olhos que numa conversação silenciosa e calada nos convidam à intimidade, a olhares, e nos levam a relações emocionais intensas.

São os designs visceral, comportamental e reflexivo atuando fortemente. Enquanto a função prática ou de uso fica "em suspensão", a função semissimbólica é que ativa o processo de descobrimento e revelação.

A aparência dos encostos é sólida, côncava, com uma base espessa e extremidades mais finas. Essa diferença de espessura proporciona a inclinação precisa e ergonômica para o conforto da peça. A união de pequenas ripas de madeira, de rica palheta de cores e texturas variadas cria uma estrutura tridimensional consistente, porém convidativa, pois o acabamento dado às peças é de tamanho esmero que a superfície parece acetinada ou aveludada. 
O Banco Siri nos confronta a proporção, o ritmo e a precisão encontrados nos encostos, frente à flexibilidade, ao descontrole, à casualidade e à intimidade da almofada. Confronta-nos o uso racional da geometria e proporções do desenho à relação emocional da beleza imperfeita dos materiais.

No Banco Siri encontramos o gesto e a poesia da designer frente ao pragmatismo do processo. 


\section{CONCLUSÃO}

Partimos do pressuposto de que as características dos produtos podem gerar reações emocionais. Por meio de características "objetivas", os objetos estimulam os sentidos; por meio das "subjetivas", significam. Estímulos e significados que, por sua vez, produzem emoções e sentimentos.

Tomando como base que as emoções são reconhecidas por meio das relações humanas que se estabelecem entre os indivíduos, assim como entre os indivíduos e o ambiente que os rodeia - e dentro dele, os objetos -, defendemos a ideia de que as emoções não permeiam apenas a mente do indivíduo biológico, mas estão presentes no contexto das relações humanas e não isoladas de seu significado social. Além de apresentarem-se biologicamente de base universal, de caráter primário, apresentam-se como emoções sociais, ligadas ao universo particular do indivíduo e geradas a partir de experiências vivenciadas em algum momento de sua formação cultural e social. Assim, estão atreladas aos valores subjetivos formados tanto pela história individual quanto por resultados de um estágio intersubjetivo. Desse modo, sustentamos a ideia que as “coisas" materiais não são emocionalmente neutras: elas geram emoções.

Dentro do argumento desta tese, identificamos alguns fatores que permeiam as emoções, condicionadas por três questões básicas e fundamentais: o contexto; a memória; e a constituição do indivíduo.

O contexto influencia, de maneira geral, a imagem que se faz do objeto. Influencia as experiências ou o modo como o objeto é percebido. A imagem que fazemos do objeto altera e afeta a compreensão do seu sentido. Por isso, a condição de um olhar culturalmente formado por vezes coloca situações de versões ou inversões do sentido e gera significados. Podemos dizer que o contexto é composto por lugares, coisas, situações e até pessoas; pela formação cultural, costumes e convenções.

Dentre os fatores condicionados pelo contexto, as experiências que temos com os objetos são as que menos sofrem influências dele. Quando falamos em experiências, a referência é aquilo que é íntimo e imediato na nossa relação direta com o objeto e corresponde a uma oscilação interna, particular, pertencente a cada um. Essa experiência imediata e íntima é fundamentalmente condicionada pelas outras experiências precedentes, inclusive aquelas com o mesmo objeto. Mesmo estando situada em um determinado tempo-espaço em termos perceptivo, a nossa mente auxilia 
para que tenhamos consciência de outras experiências, não só aquela que está presente e imediata. Toda uma bagagem de vivências acontecidas interfere ou "recheia" nossa percepção e influi sobremaneira na maneira como processamos as experiências atuais.

A capacidade que temos de lembrar o que já se passou, se viveu e se aprendeu, e relacionar isso com o presente é dada pela memória. Ela é um meio que nos permite acessar nossas experiências passadas. Experiência e memória estão profundamente relacionadas, uma mantendo e compondo a outra.

Mais que a simples tarefa de restaurar vivências, a memória é um processo de reconstituição do passado confrontado com o presente e um processo de comparação entre experiências paralelas; é um processo de construção do presente e não simplesmente um acesso ao passado: a memória dá ao ser humano a capacidade de esquecer e lembrar o que se quer e o que não se quer (CARDOSO, 2012, p.75).

O que se compõe visualmente, tatilmente ou por outros sentidos, a nós vem de longe. São imagens que são capazes de fazer "lembrar". Imagens que levam à reflexão e permitem ser experiênciadas por aquilo que deixaram ver ou sentir.

A "força" ou o "poder" dos objetos emocionais está justamente em apresentar novas imagens que, mesmo inéditas, são imaginadas e trazidas da memória. Esse é o poder da memória. E como diz Walter Benjamin:

\footnotetext{
Não cabe dizer que o passado ilumina o presente ou que o presente ilumina o passado. Uma imagem, ao contrário, é aquilo no qual o Pretérito encontra o Agora num relâmpago para formar uma constelação. Em outros termos, a imagem é dialética em suspensão. Pois, enquanto a relação do presente com o passado é puramente temporal, contínua, a relação do Pretérito com o Agora presente é dialética: não é algo que se desenrola, mas uma imagem fragmentada. (BENJAMIN, 1989 apud DIDI-HUBERMAN, 1999, p. 114)
}

A memória tem mais que a mera intenção de trazer nossas vivências, pois ela é um processo que traz o passado (Pretérito) para confrontá-lo com o presente (Agora). As experiências vivenciadas no Agora aparecem num processo de comparação entre experiências paralelas que são confrontadas e fragmentadas.

Como o momento atual é passageiro e se transforma em outros tantos momentos, a memória cumpre papel fundamental na formação do indivíduo: aquilo que pensamos e as atitudes que temos no presente são dependentes da memória.

O indivíduo tem na memória uma de suas fontes de formação. Ao fazermos contato com uma determinada pessoa, sabermos de onde vem e por quais experiências 
já passou, temos a noção de conhecê-la. Como dissemos anteriormente, a memória é um filtro, e cada um extrai do passado aquilo que considera relevante e assim constitui sua individualidade no presente.

A constituição do indivíduo é como a formação de um "material compósito", que possui vários elementos com propriedades nitidamente distintas em sua formação. Separadamente, cada um dos elementos desse compósito mantém suas características próprias, porém, quando misturados, formam um composto com propriedades impossíveis de se obter com apenas um deles. Assim, analogamente, o indivíduo é construído a partir de muitas partes e facetas, formando um todo particular.

Podemos dizer que o indivíduo está em fluxo constante e sempre sujeito a transformações, a partir do momento em que é formado pelas experiências que, por sua vez, são influenciadas pelas inclinações e filtradas pela memória.

Partindo do pressuposto de que toda emoção gera um sentimento, e, considerando que emoção é um conjunto de mudanças que ocorre tanto no cérebro (mente) quanto no corpo, sentimento seria a percepção dessas mudanças; e como registro das emoções, atuará sempre que o indivíduo se colocar diante de uma situação que possa evocá-lo, e reproduzirá emoções (positivas ou negativas) em relação a esse novo estímulo a partir de experiências anteriores.

Para que haja o sentimento, ou a percepção das mudanças, é necessário que tanto corpo quanto mente sejam constantemente informados acerca das atividades ou eventos do mundo externo. Essas informações são passadas pelos sentidos - capacidades sensoriais - que, por sua vez, são capacidades que permitem ao indivíduo perceber e acompanhar a realidade à sua volta. Contudo, é importante destacar que a apreensão dos objetos é dada a partir da experiência, e não do simples deciframento de um sentido predeterminado.

Assim, podemos dizer que se o processo de percepção resulta de estímulos internos (memórias que os indivíduos trazem consigo); externos e contextuais (aqueles propostos pelo entorno, pelos objetos, pela cultura), é nele que identificamos a emoção e os sentimentos provocados por ela. Nesse processo, a emoção atribui significado e o sentimento atribui valor.

Considerando que é no nível emocional que a experiência é assimilada e levada para a memória, é a partir dele que o indivíduo é construído.

A experiência que temos ao manipular, ou melhor, "vivenciar" um objeto vem de um processo de percepção no qual não há dualidade entre o mundo objetivo e o 
mundo do sentir: o sujeito perceptivo percebe e o conhecimento é interpretação de tal percepção.

A compreensão do indivíduo que sente o "dado" sensível não é elemento estanque: é por meio dos processos das trocas sensoriais que determinamos o mundo e que damos significado a ele, ou seja, um processo no qual há o estabelecimento de relações "entre o sujeito da sensação (objeto) e o seu sensível (homem)" (MERLEAUPONTY, 1999, p. 287), ou como disse Damásio (2004, p. 98), entre o corpo (homem) e objeto emocionalmente competente (objeto), e é nessas relações que se dá início à cadeia emoção - sentimento. No nosso caso, os objetos de design - sujeitos da sensação ou os objetos emocionalmente competentes - são responsáveis pelo estabelecimento de uma construção interna que se faz desses objetos. São eles, justamente, a origem imediata da percepção e do sentimento.

Por outro viés, que não o da experiência, mas o das funções que os objetos apresentam em si, definimos que os objetos possuem três funções básicas: as semissimbólicas, as práticas ou de uso e as funções técnicas. Defendemos que a relação do indivíduo com o produto se dá tanto por meio das motivações subjetivas dentro um sistema de valores próprios quanto por meio de um sistema de referências sociais e culturais partilhadas pela coletividade (motivações intersubjetivas), ou seja, quando as emoções apresentam-se como emoções sociais.

Demos especial importância ao desenvolvimento das funções semissimbólicas, pois acreditamos serem elas as que mais propiciam os processos de significação e as aberturas necessárias aos processos emocionais. É no indivíduo e na sua intersubjetividade que as funções semissimbólicas dos objetos acontecem.

Definimos os objetos emocionais como aqueles que estão aptos a oferecer ressignificações e ressimbolizações ao longo do cotidiano imediato ou ao longo da vida do sujeito, pois têm a capacidade de deslumbrar imagens, relações, emoções e sentimentos que o indivíduo carrega consigo. São objetos que desempenham uma função que regula e ajusta o nosso cotidiano, pois permitem uma troca, cujo investimento afetivo não é dado apenas ao "corpo material”, mas a um sentido ao qual o indivíduo constitui e reconstitui um mundo, uma totalidade afetiva e privada.

Para tanto, tendo como premissa que as questões emocionais são dadas pelas qualidades objetivas (material, funcionalidade, operacionalidade) e subjetivas (significados e processos de significação), não consideramos os objetos emocionais 
como "objetos acabados", contidos em si mesmos, mas objetos "abertos", que atendem à função semissimbólica e são emocionalmente competentes.

Relacionando tais conceitos aos objetos físicos de nossa pesquisa - os móveis domésticos brasileiros - ao estudarmos primeiramente o contexto geral dos móveis domésticos, destacamos na história períodos em que ora eram utilizados como objetos de função puramente utilitária, ora exerciam funções de dimensões emocionais e semissimbólicas.

Como demonstrado na Parte II, em determinados períodos, quando as atividades público-privadas eram coincidentes dentro da casa, o móvel adquiriu uma natureza mais utilitária e "multifuncional", na qual as funções práticas ou de uso e as técnicas eram as mais proeminentes, levando-nos a observar uma relação emocional mais no nível comportamental.

À medida que as condições da vida doméstica começaram a se transformar, há um maior desejo de privacidade, o que se refletiu no ambiente interno. A partir dessas transformações, os móveis assumem outras características e passam a ser mais bem adaptados aos padrões requeridos. Começam, assim, a não mais serem vistos como aqueles de caráter apenas utilitário, pois à medida que a vida se tornava igualmente íntima e social, os móveis iam aumentando em número e em diversificação, e sua relação com o indivíduo ia se tornando mais particularizada. Os móveis iam adquirindo características peculiares e distintas a cada situação. Foi a partir dessa fase que houve uma clara posição das relações entre as funções assumidas e dadas aos móveis enquanto objetos de funções de uso e semissimbólica. Para cada situação, os móveis assumiam papéis diferenciados: um de utilidade, outro de intimidade.

Paralelamente às questões das funções do móvel especificamente, começam a aflorar as outras ações acerca da incorporação dos processos industriais na fabricação. Não se poderia mais projetar com base nas formas do passado: haveria de se encontrar uma nova linguagem para os produtos industrializados.

Foi no Movimento Moderno que houve uma ruptura total com o passado e com aquilo que fundou, aprimorou e desenvolveu o móvel e a configuração do espaço interior até então e sua relação com o indivíduo.

O racionalismo, as novas formas de distribuição funcional, a repetição e a simetria foram estabelecidos e os modos de habitar e usar os objetos foram profundamente alterados a partir de propostas estandardizadas. 
O modelo standard distanciou de modo decisivo a individualidade e a diversidade do indivíduo, que se viram detidas pelo padrão. Como consequência, a perda de identidade da casa e do sujeito. A autonomia dada ao objeto e aos processos de produção industrial foi de tal dimensão que se vetou toda e qualquer aproximação do sujeito subjetivo.

Contudo, a complexidade, a mutabilidade e a indeterminação da vida do sujeito contemporâneo acabam por fazer com que se repense o interior doméstico, estabelecendo um cenário que melhor se adapte ao seu estilo de vida. A permanência, a previsibilidade e a rigidez, que caracterizaram o projeto moderno, foram substituídas por mecanismos abertos que se ajustam em diversas manifestações e combinações. Nessa situação o indivíduo reaparece e suas latências começam a se tornar realidades.

Dentro desse contexto, os aspectos afetivos e emocionais são foco na tentativa de se lidar com essa crescente complexidade.

Como diz Bauman (2007), o indivíduo está imerso numa sociedade "líquida", que se conforma e deforma com facilidade, e por isso tenta, de várias formas, recuperar a sua individualidade.

Assim, os móveis, que ora se sobressaíam em suas funções técnicas ou de uso, ora em suas funções semissimbólicas, guardam segredos e propõem relações, criam e recriam realidades. Pertencentes ao domínio entre o público e o privado, são aqueles pelos quais os sujeitos falam de si próprios, de suas memórias, sonhos e valores.

O móvel se circunscreveu na formação do cotidiano, do lar e da casa, e, como participante ativo da condição de morar, é um objeto com fortes características semissimbólicas atribuídas por aquele que lhe tem necessidade e desejo. A relação já não é mais arbitrária e normativa, destinada ao uso sem reflexão, mas sim estabelecida por meio do uso e das emoções para reflexão.

Enquanto estudo do objeto "móvel doméstico brasileiro", ficou evidente que a herança do uso da madeira e de suas técnicas tradicionais, consequentes das diferentes culturas trazidas pelos portugueses; os costumes culturais e sociais dos povos já presentes e daqueles que começaram a habitar o país; e o hibridismo apresentado pelas formas, estilos e técnicas construtivas que permearam a produção e a inserção do mobiliário na realidade do cotidiano colonial foram práticas marcantes que influenciaram intensamente o desenvolvimento do design do mobiliário brasileiro, bem como se firmaram como referência simbólica no imaginário do povo. 
Tais manifestações são tidas como de grande alcance simbólico e colocam-nos frente à subjetividade e seleção que o processo de memória solicita. Entregam-nos um passado arraigado de grande referência e singeleza. Assim, a busca às tradições, em que as representações do passado sempre foram bases que igualmente dialogaram com o presente; em que os resgates são carregados de diversos significados e intenções; em que o presente advém do passado de forma harmônica e generosa, é, sem sombra de dúvida, referência que se abre à experiência semissimbólica e à experiência emocional.

Isso nos leva a observar que, durante o processo de industrialização e implantação do design no Brasil, houve, em princípio, uma aceitação acerca dos fatores produtivos e das prerrogativas que condicionavam os objetos aos procedimentos funcionais, nos quais se deveria buscar a forma como expressão manifesta de sua função de uso. Contudo, essa predeterminação funcionalista que propunha um esvaziamento de sentido foi se alterando na medida em que as linguagens foram sendo construídas baseadas na descoberta das possibilidades dos materiais abundantes e nas tradições culturais (materiais e imateriais), criando soluções de acordo com a realidade do país. Ou seja, ao passo em que houve a busca por acepções que viabilizassem o pensamento racional e estandardizado, houve também uma forte investigação acerca de uma linguagem própria.

Assim, essa condição, dada por meio de buscas às raízes e práticas culturais, bem como à experimentação de materiais nativos e corriqueiros junto ao povo, proporcionou ao design do móvel uma característica muito particular no cenário do design brasileiro.

Os processos de ressimbolização e ressignificação, inerentes aos objetos emocionais, sempre atuaram de modo presente e permanente na concepção e produção do mobiliário brasileiro, tanto na incorporação dos móveis vindos de Portugal quanto no surgimento das propostas modernistas. Por mais que o Funcionalismo e os preceitos pragmáticos da produção industrial se fizessem presentes no cotidiano projetual, as propostas que surgiam sempre apresentaram um alto grau de liberdade e criação, fosse por meio do uso das referências da herança dos estilos coloniais, do tradicional, fosse pelo uso das técnicas e materiais, ou por certa liberdade projetual apresentada pelos designers e arquitetos.

Nesses "objetos móveis", que se movimentam, se deslocam e que nos mobilizam, não existem formas "excêntricas" ou esvaziamento de conceito, mas aquilo que lhes dá sentido. Um sentido visceral, um sentido comportamental ou um sentido 
reflexivo: sempre um sentido. Um sentido que nos leva à reflexão por meio de relações, sejam essas pelo uso, pelas práticas ou pelas relações subjetivas e intersubjetivas.

Ao identificarmos seis características do design moveleiro no cenário contemporâneo, pudemos também localizar alguns fortes indícios que nos levaram a confirmar nossa hipótese inicial: que as prerrogativas que delimitam o conceito de design emocional sempre constituíram o objeto e o fazer projetual em grande parte desse setor.

Isso se dá desde os pioneiros e contemporâneos, que carregavam consigo a vontade de mudanças e participavam ativamente de um período que propunha uma reavaliação do que significavam "ser e fazer brasileiro"; aos preceitos do modernismo que foram se absorvendo (ou dissolvendo) numa maneira especial de tradução e assimilação; à caracterização cultural, social e política contemporânea que incorporou de maneira singular o conceito de brasilidade; às possibilidades projetuais e mudanças na conceituação dos processos de design que permitiram que os limites entre arte $e$ design fossem desmistificados quando da época do design funcionalista; aos processos artesanais herdados do próprio fazer no setor, que nunca deixaram de ser uma poderosa fonte de experimentação para os designers; e por fim, à multiplicidade de conceitos e tecnologias, que ora comemoram o passado, ora ultrapassam os limites rumo ao futuro, mas que integram todas as prerrogativas já citadas de maneira a propiciar aquilo que consideramos essencial: objetos que valorizam a relação entre objeto e indivíduo.

Foi nesse panorama histórico que, efetivamente, conseguimos identificar como foram as relações e as proposições que marcaram o design do mobiliário brasileiro dentro dos conceitos que margeiam a relação entre indivíduo e objeto.

Ao escolhermos a Poltrona Mole, a Cadeira Vermelha e o Banco Siri como legítimos representantes daquilo que denominamos objetos emocionais, destacamos um poder inerente aos três: o de levantar os olhos, como defende Benjamin (1994). Ao contrário dos objetos do Funcionalismo - que eram destituídos de experiência, pois propunham a anulação do indivíduo em prol do universal -, os objetos emocionais propõem certo "inacabamento" de sentido, pois não têm um significado totalmente fixo.

Para tanto, as qualidades de mobilização que nos levam à produção de sentido apresentadas pela Poltrona Mole, por exemplo, quando nos aludem a um passado tradicional de utilização de materiais nativos, com suas texturas, cores e odores; ou com suas formas e usos que nos remetem a um "ser brasileiro", são adjetivos que nos formam imagens atualizadas que se alteram no próprio processo da experiência. 
Na Cadeira Vermelha, a realidade dos Irmãos Campana não difere daquela vivida por qualquer outra pessoa: os temas trabalhados estão ligados à crônica da vida cotidiana. A técnica por eles utilizada, do gesto, do ato, do fazer e construir leva a uma imagem que não se liberta totalmente da matéria. A cor ou o material propriamente dito não constitui uma linguagem que manifesta uma imagem; antes, é na matéria que, sob a ação da técnica, do fazer e do gesto, torna-se imagem na qual há uma desconstrução do material para a reconstrução de novos sentidos.

A mesma situação se confere ao Banco Siri. A estrutura por nós denominada "almofada" ou "cama" nos remete ao passado afetivo, às lembranças de intimidade. Já os encostos, por meio de sua estrutura formal, são personagens em situação de "conversação" muda; são os olhos (do Siri) do móvel que nos olham e nos levam a experiências que nos movem e mobilizam de distintas maneiras.

Assim, reafirmamos que, dentro dos conceitos trabalhados, as formas dos objetos não possuem um significado fixo, mas são expressivas de um processo de significação, onde há a permuta entre aquilo que está embutido em sua situação material e aquilo que pode ser depreendido por nossa experiência. Para tanto, o conceito "móvel" do móvel, dado por sua utilidade de mobilidade, é também, e principalmente, dado pelo sujeito, pois é ele quem imputa o poder "móvel” do processo de significação. Movemse: significados, afetos, emoções e sentimentos.

Se, por um lado, conseguimos detectar que as formas são respostas concretas aos conceitos deferidos por sua criação (projeto), por outro, formas e objetos são passíveis de adaptação pelo uso e sujeitos a mudanças de percepção pelo juízo.

Assim, surgiram alguns pontos fundamentais que nos guiaram a uma conclusão que entendeu o processo emocional dentro do cenário do mobiliário brasileiro. Essa conclusão está pautada em três itens: conceitos norteadores, o fazer projetual e a categoria dos objetos.

O primeiro ponto é com relação aos conceitos que foram surgindo ao longo da análise e tornaram-se proeminentes:

\section{a. Sobre a identidade}

Como um conceito mais geral que os outros abaixo, se entende que as bases da valorização de imagens simbólicas e de referência da cultura brasileira tradicional, incutidas no imaginário social coletivo sob a égide dos códigos visuais, dos materiais e da tradição construtiva, são fundamentos para a valorização emocional dos objetos. 


\section{b. Experimentações: vocabulário brasileiro e o desenho da diferença}

Este conceito permeia a noção de utilidade dos objetos e a dimensão cultural dentro da relação de dualidade entre design e arte. Formas que extraem do cotidiano popular uma nova ordem e um novo gesto que retratam a expressão e a força poética.

\section{c. Tradição - O resgate das técnicas manuais e o fazer artesanal}

Detectamos a utilização de técnicas artesanais como instrumento no processo produtivo e como valor simbólico agregado ao objeto. Esse valor simbólico está diretamente relacionado à tradição histórica - o ofício artesanal atravessou todo o processo de industrialização e se mantém vivo como tradição.

Esses três conceitos formam uma base sólida que particulariza o móvel doméstico brasileiro desde suas primeiras experimentações até a contemporaneidade.

O segundo ponto, diz respeito ao próprio fazer projetual brasileiro específico para esse setor e suas consequências:

a. O "fazer" mobiliário brasileiro cresceu juntamente com a formação de nossa cultura, sofreu influências das várias situações e conjunturas em sua formação;

b. Enquanto objetos, não surgiram nem foram desvirtuados de suas prerrogativas com a formação e implantação da indústria e seus preceitos; houve um posicionamento que se manteve sólido com relação ao encantamento do racionalismo industrial;

c. Diferentemente de outros objetos, o desenvolvimento do mobiliário brasileiro na categoria "design de autor" não se deu a partir da intensa influência da escola funcionalista implantada no Brasil na década de 1960, que rezava a cartilha da Escola de Ulm.

Isso demonstra claramente que o fazer projetual nesse setor sempre manteve certa independência e liberdade frente às questões que imperavam como condições de crescimento e desenvolvimento do país.

O ultimo e terceiro ponto, é uma categoria especial de objeto, pois possui uma relação muito íntima com o indivíduo, que advém do conceito de lar como intimidade e proteção e do entendimento daquilo que é privado, particular e íntimo.

Assim, não são objetos "verdade", fixos e acabados em si mesmos, mas aqueles que permitem que o olhar do indivíduo trabalhe no tempo, na história e na experiência. 
São objetos "móveis", objetos emocionais porque "o que vemos só vale - só vive - em nossos olhos pelo que nos olha." (DIDI-HUBERMAN, 1999, p. 29). 


\section{REFERÊNCIAS}

ABOULAFIA, A.; BANNON, L. J. Understanding affect in design: an outline conceptual framework. Theor. Issues in Ergon. Sci, v. 5, n. 1, p. 4-15, 2004.

ALFRED, D. Campana brothers: complete works (so far). Nova York: Rizzoli International Publications, 2010.

ALLEAU, R. La Science des Symboles. Paris: Payot, 1976.

ALMOUNT, J. A imagem. Campinas: Papirus, 1993.

ARGAN, G. C. Arte Moderna. São Paulo: Companhia das Letras, 1992a. $1992 b$.

História da arte como história da cidade. Rio de Janeiro: Martins Fontes,

Clássico anticlássico: o renascimento de Brunelleschi a Bruegel. São Paulo: Companhia das Letras, 1999.

ARNHEIM, R. Arte e percepção visual: uma psicologia da visão criadora. São Paulo: Pioneira, 2001.

AVIANI, F. L.; COSTA JUNIOR; J. A. Móvel Moderno Brasileiro na Universidade de Brasília. In: Muiradesign: Marchetaria com madeiras alternativas da Amazônia. Brasília: Editora Universidade de Brasília, 2013.

ASHBY, M.; JOHNSON, K. Materials and design: the art and science of materials selection in product design. Reino Unido: Elsevier Butterworth Heinemann, 2002.

AZEVEDO, J. R. Distúrbios na memória: novas perspectivas. Disponível em: <www.ficarjovemlevatempo.com.br>. Acesso em: junho de 2014.

BAKHTIN, M. Questões de literatura e de estética: a teoria do romance. São Paulo: Hucitec, 1990.

Estética da criação verbal. São Paulo: Martins Fontes, 1992.

BARTHES, R. Mitologias. Rio de Janeiro: DIFEL,1971.

BATISTA, W. B. Frankfurt e Bauhaus: vertentes críticas do Desenho Industrial. In: Estudos em Design, v. 8, n.3. Rio de Janeiro: AEnD, 2001.

BATTARBEE, K.; MATTELMÄKI, T. Meaningful product relationships. In: MCDONAGH, D. et al. (Org.). Design and emotion: the experience of everyday Things. London: Taylor\&Francis, 2004.

BAUDRILLARD, J. O sistema dos objetos. São Paulo: Perspectiva, 1993.

BAUMAN, Z. Tempos líquidos. Rio de Janeiro: Jorge Zahar Editor, 2007.

BAXTER, M. Projeto de produto: guia prático para o desenvolvimento de novos produtos. São Paulo: Editora Edgard Blücher, 1998.

BAYEUX, G. O móvel da casa brasileira. São Paulo: Ed. Museu da Casa Brasileira, 1997.

BECCARI, M. N. Articulação simbólica: uma abordagem junguiana aplicada à Filosofia do Design. 2012. Dissertação (Mestrado em Design) - Programa de PósGraduação em Design, Universidade Federal do Paraná, 2012. 
BECK, U.; GIDDENS, A.; LASH, S. Modernização reflexiva: política, tradição e estética na ordem moderna social. São Paulo: Editora da Universidade Estadual Paulista, 1997.

BENJAMIN, W. Louis-Philippe or the Interior. In: Charles Baudelaire: a lyric poet in the era of high capitalism. London: NLB, 1973.

Experiência e pobreza. In: política. São Paulo: Editora Brasiliense, 1994a.

A obra de arte na era de sua reprodutibilidade técnica. In: Obras

escolhidas 1: magia e técnica, arte e política. São Paulo: Ed. Brasiliense, 1994b.

BIANCARDI, C. S. C. In: ACERVO ARTÍSTICO-CULTURAL DOS PALÁCIOS DO GOVERNO. Mobiliário artístico e histórico. São Paulo, 1988.

BOMFIM, G. A. Idéias e formas na história do design. João Pessoa: Editora Universitária, 1998.

BOMFIM, G. A.; ROSSI, L. M. Moderno e pós-moderno, a controvérsia - caminhos de uma discussão sobre a estética e a semântica do produto industrial. Florianópolis: LDP-DI/SC, 1989.

BOURDIEU, P. A economia das trocas simbólicas. São Paulo: Editora Perspectiva, 1974.

Sociologia. São Paulo: Ática, 1983.

BOYLE, C. (Ed.). O mundo doméstico. Rio de Janeiro: Abril Livros, 1993.

BRIDGEMAN, B. Biología del comportamento y de la mente. Madrid: Alianza, 1991.

BROSIG, P. O mobiliário na habitação popular. Dissertação (Mestrado em Arquitetura e Urbanismo) - Programa de Pós-graduação da Faculdade de Arquitetura e Urbanismo, Universidade de São Paulo, São Paulo, 1985.

BÜRDEK, B. E. Design: história, teoria e prática do design de produtos. São Paulo: Editora Edgard Blücher, 2006.

CALS, S. (org.). Sergio Rodrigues. Rio de Janeiro: S. Cals, 2000.

CAMPANA, H. Campanas. São Paulo: Bookmark, 2003.

. Irmãos Campana. Revista Casa e Jardim. Edição 590. Rio de Janeiro: 2004.

CANCLINI, N. G. Culturas híbridas, estratégias para entrar e sair da modernidade. São Paulo: EDUSP, 1990.

CANTI, T. O móvel no Brasil. Origens, evolução e características. Rio de Janeiro: Candido Guinle de Paula Machado, 1985.

CARDOSO, D. Design para um mundo complexo. São Paulo: Cosac Naify, 2012.

CASTELLS, M. Therise of the network society. Massachusetts: Blackwell Publishers, 2000.

CAVALCANTI, A. C. Símbolo e alegoria - a gênese da concepção de linguagem em Nietzsche. São Paulo: Annablume, 2005. 
CAVALCANTI, V. P. O design do móvel contemporâneo brasileiro: da diversidade à especificidade. Tese (Doutorado em Arquitetura e Urbanismo) - Programa de Pósgraduação em Arquitetura e Urbanismo, Universidade de São Paulo, São Paulo, 2001.

CHRISTIANSON, S. A. The handbook of emotion and memory. New Jersey: Lawrence Erlbaum Associates, 1992.

CONSIGLIERI, V. As significações da arquitetura 1920-1990. Lisboa: Ed. Estampa, 2000.

CORONA, E.; LEMOS, C. A. C. Dicionário da arquitetura brasileira. São Paulo: EDART, 1972.

CORREIA, C. J. Ricoeur e a expressão simbólica do sentido. Lisboa: Fundação Calouste Gulbenkian, 1999.

COSTA, L. Notas sobre a evolução do mobiliário luso-brasileiro. In: Arquitetura Civil II - mobiliário e alfaias. São Paulo: FAU - USP / MEC-IPHAN, 1975.

CYBIS, W.; BETIOL, A. H.; FAUST, R. Ergonomia e Usabilidade: conhecimentos, métodos e aplicações. São Paulo: Novatec, 2007.

DAMÁSIO, A. R. O mistério da consciência: do corpo e das emoções ao conhecimento de si. São Paulo: Cia das Letras, 2000.

Em busca de Espinosa: prazer e dor na ciência dos sentimentos. São Paulo: Companhia das Letras, 2004.

O erro de Descartes. 2. ed. São Paulo: Companhia das Letras, 2006.

DAMAZIO, V.; LIMA, J.; MEYER, G. "Marcas que marcam" e a antropologia do consumo: caminhos para projetar produtos "marcantes". In: MONT'ALVÃO, Claudia; DAMÁZIO, Vera (Org.). Design, ergonomia e emoção. Rio de Janeiro: Mauad X: FAPERJ, 2008.

DEMBER, W. N. Psicología de la percpción. Madrid: Alianza, 1990.

DENIS, R. C. Design, cultura material e o fetichismo dos objetos. In: LEITE, J. S. et al. Arcos: design, cultura material e visualidade. Rio de Janeiro: Contra Capa, 1999.

Uma introdução à história do design. São Paulo: Ed. Edgard Blücher, 2000.

DESMET, P. M. A. Desining emotions. Tese (Doutorado) - Technisch Universiteit Delft, Deltf, Holanda, 2002.

DIDI-HUBERMAN, G. O que vemos, o que nos olha. São Paulo: Editora 34, 1998.

DUFRENNE, M. Estética e filosofia. São Paulo: Editora Pespectiva, 1998.

DURAN, G. A imaginação simbólica. São Paulo: Cultrix; EDUSP, 1988.

DURIE, B. Portas da percepção. Revista Mente e Cérebro, São Paulo, n. 12, p. 6-9, 2008.

DUTCOSKY, S. D. Análise sensorial dos alimentos. Curitiba: Champagnat, 2007.

FERRARA, L. D. A estratégia dos signos: linguagem, espaço, ambiente urbano. São Paulo: Perspectiva, 1986.

FLUSSER, V. The shape of things: a philosophy of design. Londres: Reaktion Books, 1999. 
. Uma filosofia do design: a forma das coisas. Lisboa: Relógio D’Água Editores, 2010.

O mundo codificado: por uma filosofia do design e da comunicação. São Paulo: Cosac Naify, 2007.

FOLZ, R. R. Mobiliário na habitação popular - discussões de alternativas para melhoria da habitabilidade. São Paulo: Ed. Rima, 2003.

FORLIZZI, J.; DISALVO, C.; HANINGTON, B. On the relationship between emotion, experience and the design of new products. The Design Journal, v. 6, Issue 2, p.29-38, 2003.

FORLIZZI, J.; FORD, S. The building blocks of experience: an early framework for interaction designers. Proceedings of DIS. New York: ACM Press, 2000.

FORTY, A. Objetos de desejo. São Paulo: Cosac Naify, 2007.

FREUD, S. "O Estranho". In: História de uma neurose infantil. Rio de Janeiro: Imago, 1969. v. XVII.

FREYRE, Gilberto. Casa grande e senzala. São Paulo: Global Editora, 2013.

GIDDENS, A. The consequences of modernity. [S.1.]: Polity Press, 1990.

GOMBRICH, E. H. A história da arte. Rio de Janeiro: LTC, 1999.

HALL, S. A identidade cultural na pós-modernidade. Rio de Janeiro: DP\&A Editora, 2001.

HEKKERT, P. Design aesthetics: principles of pleasure in product design. Psychology Science, n. 48, 2006, p. 157-172.

HEKKERT, P.; RUSSO, B. Sobre amar um produto: os princípios fundamentais. In: MOANT’ALVÃO, Claudia; DAMÁZIO, Vera (Org.). Design, ergonomia, emoção. Rio de Janeiro: Mauad X; Faperj, 2008.

HESKETT, J. Desenho industrial. Rio de Janeiro: José Olympio, 1997.

HILLMAN, J. Psicologia arquetípica: um breve relato. São Paulo: Cultrix, 1995.

IIDA, I. Ergonomia: projeto e produção. São Paulo: Editora Edgard Blücher, 1990.

IZQUIERDO, I. Memória. Porto Alegre: ArtMed, 2002.

JÄÄSKÖ, V.; MATTELMAKI, T.; YLIRISKU, S. The scene of experiences. In: COST269 CONFERENCE, Finland, 2003. Proceedings of the Good, the Bad \& the Irrelevant - The user and the future of information and communication technologies. Finland: COST \& Medialab UIAH, 2003.

JEUDY, H. P. Philippe Starck: ficção semântica. In: LEITE, J. S. et al. Arcos: design, cultura material e visualidade. Rio de Janeiro: Contra Capa, 1999.

JOLY, M. Introdução à análise da imagem. Campinas: Papirus, 1996.

JORDAN, P. Designing Pleasurable Products: An Introduction to the New Human Factors. London: Taylor \& Francis, 2000.

JUNG, C. G. O homem e seus símbolos. Rio de Janeiro: Nova Fronteira, 2008.

KANDEL, E. R.; SCHWARTZ, J. H.; JESSEL, T.M. (org). Fundamentos da neurociência e do comportamento. Rio de Janeiro: Guanabara Koogan, 1997. 
KANT, I. Crítica da faculdade do juízo. Rio de Janeiro: Forense Universitária, 2002.

KARANA, E. Intangible characteristics of materials in industrial design. In: CONFERENCE ON DESIGN \& EMOTION, 5., 2006. Anais Suécia: [S.n.], 2006.

KARANA, E; KESTEREN, I. van. Materials \& design: the art of plastics design. Delft University of Technology, 2006. Disponível em: <http://www.io.tudelft.n1/live/pagina.jsp?=a7c9996c-4a94-43db-94acd1ddcded97a9\& lang=en>. Acesso em: jun. 2008.

KATINSKY, J. R. As cinco raízes formais do desenho industrial. In: LEITE, J. S. et al. Arcos: design, cultura material e visualidade. Rio de Janeiro: Contra Capa, 1999.

KHALID, H. M. Embracing diversity in user needs for affective design. Applied Ergonomics 37, 2006. Disponível em: <www. Elsevier.com/locate/apergo>. Acesso em: junho de 2008.

KHALID, H. M.; HELANDER, M. G. Customes emotional needs in product design. In: CE, Concurrente Engineering: Research and Applications, 2006.

KÖHLER, W. Psicologia da Gestalt. Belo Horizonte: Editora Itatiaia, 1980.

KRIPPENDORFF, K. On the essential contexts of artifacts or on the proposition that "design is making sense (of things)". In: MARGOLIN, V.; BUCHANAN, R. (Org.). The idea of design: a design issues reader. Cambridge: The MIT Press, 1996.

LABOURTHE-TOLRA, P.; WARNIER, J.P. Etnologia - antropologia. Rio de Janeiro: Vozes, 1997.

LE COURBUSIER. A arte decorativa de hoje. São Paulo: Martins Fontes, 1996.

LEDOUX, J., O cérebro emocional. Os misteriosos alicerces da vida emocional. Rio de Janeiro: Objetiva, 2001.

LEMOS, C. A.C. História da casa brasileira. São Paulo: Ed. Contexto, 1989.

Cozinhas, Etc: um estudo sobre as Zonas de Serviço da Casa Paulista. São Paulo: Editora Perspectiva, 1978.

LEON, E. Zanine, o mago da madeira. Famoso por sua arquitetura, José Zanine Caldas se revela pioneiro no design de móveis populares. Design \& Interiores, São Paulo, ano 2, n.14, 1989.

LINDSTROM, M. Brandsense: a marca multissensorial. Porto Alegre: Bookman, 2007.

LÖBACH, B. Design industrial: bases para a configuração dos produtos industriais. São Paulo: Ed. Edgard Blücher, 2000.

LOURENÇO, M. Releitura das ambientações brasileiras - cinco séculos de História. São Paulo: Ed. SENAC, 2003.

LUDDEN, G. D. S.; SCHIFFERSTEIN, H. N. J.; HEKKERT, P. Sensory incongruity: comparing vision to touch, audition and olfaction. In: DESIGN AND EMOTION CONFERENCE, 5., 2006. Proceedings... Sweden: [S.n,], 2006, p.1-17.

MACEDO, M. M. Semiótica plástica na análise de cartazes de cinema Metaforização de estigmas sociais em cartazes. Trabalho de conclusão de curso (Graduação em Comunicação Social) - Universidade Federal do Rio Grande do Sul, UFRS, 2008. 
MATURANA, H. Cognição, ciência e vida cotidiana. Belo Horizonte: UFMG, 2001. McLUHAN, M. Os meios de comunicação como extensões do homem. São Paulo: Cultrix, 1999.

MELLO e SOUZA, L. de. História da vida privada no Brasil 1 - cotidiano e vida privada na América portuguesa. São Paulo: Companhia das Letras, 1997.

MERLEAU-PONTY, M. Fenomenologia da percepção. São Paulo: Martins Fontes, 1999.

MOLES, A. Teoria dos objetos. Rio de Janeiro: Ed. Tempos Brasileiros, 1981.

MORAES, D. de. Análise do design brasileiro: entre mimese e mestiçagem. São Paulo: Ed. Edgard Blücher, 2006.

MOURA, G.; RICCETTI, T. M. O lar do futuro. In: $9^{\circ}$ CONGRESSO BRASILEIRO DE PESQUISA E DESENVOLVIMENTO EM DESIGN, 2010. Anais.. São Paulo: Universidade Anhembi Morumbi, 2010.

MOUTINHO, S. R. O. Dicionário de artes decorativas e decoração de interiores. Rio de Janeiro: Nova Fronteira, 1999.

MUKAROVSKY, J. Escritos sobre estética e semiótica da arte. Lisboa: Ed Estampa, 1981.

MUSEU DA CASA BRASILEIRA. O Museu da Casa Brasileira. São Paulo: Banco Safra, 2002.

NIEMEYER, L. Design atitudinal: uma abordagem projetual. In: MOANT’ALVÃO, Claudia; DAMÁZIO, Vera (Org.). Design, ergonomia, emoção. Rio de Janeiro: Mauad X; Faperj, 2008.

NÓBREGA, C. M. da. Há_bit: tratado superficial de arquitetura cíbrida. Tese (Doutorado em Artes) - Programa de Pós-graduação em Artes, Universidade de Brasília, Brasília, 2011.NORMAN, D. A. O Design do dia-a-dia. Rio de Janeiro: Rocco, 2006.

NORMAN, D. Design emocional - por que adoramos (ou detestamos) os objetos do dia-a-dia. Rio de Janeiro: Rocco, 2008.

OATES, P. B. História do mobiliário ocidental. Lisboa: Ed. Presença, 1991.

ONO, M. M. Design industrial e diversidade cultural: sintonia essencial. 2004. Tese (Doutorado em Arquitetura e Urbanismo) - Programa de Pós-graduação em Arquitetura e Urbanismo, Universidade de São Paulo, São Paulo, 2004.

PEDREIRA, L. Designer acidental. Casa Vogue, São Paulo, ano 15, n. 2., 1991.

PERROT, M. (Org.). História da vida privada, 4: da revolução francesa à primeira guerra. São Paulo: Companhia das Letras, 2009.

PERSON, O. Usability is not enough: first underline of functional model for describing emotional response towards products. Disponível em: <http://design2.maskin.ntnu.no/fag/PD9/2003/artikket/Person.pdf>. Acesso em: 2007.

PEVSNER, N. Os pioneiros do desenho moderno. São Paulo: Martins Fontes, 1994.

PIGNATARI, D. Semiótica da arte e da arquitetura. São Paulo: Editora Cultrix, 1995.

PISANI, E. M. et al. Psicologia geral. Porto Alegre: Vozes, 2000. 
QUEIROZ, S. G. A Dimensão estético-simbólica dos produtos na relação afetiva com usuários. Tese (Doutorado em Engenharia de Produção) - Programa de Pósgraduação em Engenharia de Produção, Universidade Federal de Santa Catarina, UFSC, 2011.

ROCHA, C. E. O mobiliário antigo na Bahia. Salvador: [S.n.], [S.d].

RUSKIN, J. The seven lamps of architecture. Nova York: Hill and Wang, 1989.

RYBCZYNSKI, W. Casa: pequena história de uma idéia. Rio de Janeiro: Ed. Record, 1999.

SANTAELLA, L. O que é semiótica. São Paulo: Brasiliense, 1983.

SANTANA, P. A. (Org.). Design Brasil: 101 anos de história. São Paulo: Ed. Abril, 2010.

SANTOS, M. C. L.; RODRIGUES, Sergio. Redescobrindo o Brasil pelo móvel. In: RODRIGUES, Sergio. Falando de cadeira: retrospectiva 1954/1991. Rio de Janeiro: Museu de Arte Moderna do Rio de Janeiro, 1992.

SANTOS, M. C. L. Móvel moderno no Brasil. São Paulo: Studio Nobel, FAPESP/EDUSP, 1995.

SAUSSURE, F. de. Curso de lingüística geral. São Paulo: Cultrix, 1988.

SCHIMIDT, J. E. La percepcion del habitat. Barcelona: Gustavo Gilli, 1974.

SCHNEIDER, B. Design - uma introdução. O design no contexto social, cultural e econômico. São Paulo: Blücher, 2010.

SIEGEL, D. A mente em desenvolvimento: para uma neurobiologia de experiência interpessoal. Lisboa: Instituto Piaget, 2004.

SIMONDON, G. Du mode d'existence dês objects techniques. Paris: Aubier, 1989.

SONNEVELD, M. Aesthetics of tactual experience. Dissertation (Doctoral) - Delft University of Technology, 2007.

STRONGMAN, K. T. The psychology of emotion: from everyday life to theory. England: John Wiley \& Sons Ltd, 2003.

SURI, J. F. The experience of evolution: developments in design practice. The Design Journal, v. 6. Issue 2, p. 39-48, 2003.

VAN der LINDEN, Júlio. Ergonomia e design: prazer, conforto e risco no uso de produtos. Porto Alegre: UniRitter Ed., 2007.

WINCKELMANN, J. J. Historia del arte em la antigüedad. Barcelona: Ediciones Folio, 2002.

WÖLFFliN, H. Conceitos fundamentais da História da Arte. São Paulo: Martins Fontes, 1984.

\section{SITES CONSULTADOS}

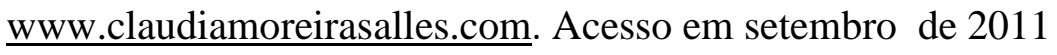

www.furniturestyles.net. Acesso em setembro de 2011 
www.sergiorodrigues.com.br/. Acesso em setembro de 2011

http://decor-acao.blogspot.com.br/ . Acesso em setembro de 2011

www.belvederellc.com/kitchenbaths. Acesso em setembro de 2011

Www.mcb.org.br. Acesso em setembro de 2011

tipografos.net/design/tenreiro.html. Acesso em setembro de 2011

http://casadaidea.com.br/arquitetura/lina-bo-bardi-arquitetura/. Acesso em setembro de 2011

www.designcultura.org/menu/moveis/conte/quadro.html. Acesso em setembro de 2011

http://theredlist.com/wiki-2-18-392-1335-1353-1455-view-brazilian-modernism-profilezanine-caldas-jose.html. Acesso em setembro de 2011

$\underline{\text { www.useche.com.br/english/flash.aspx }}$. Acesso em setembro de 2011

www.barauna.com.br/. Acesso em setembro de 2011

www. domusweb.it. Acesso em abril de 2014

www.campanas.com.br . Acesso em abril de 2014

www.vitra.com. Acesso em abril de 2014

www.edra.com/. Acesso em maio de 2014

www.firmacasa.com.br/. Acesso em maio de 2014

http://casa.abril.com.br/materia/oscar-niemeyer-marquesa. Acesso em agosto de 2014

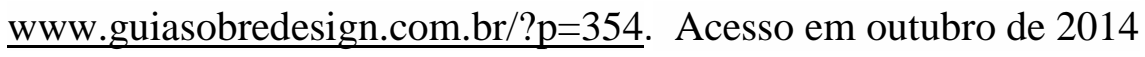

www.livingdesign.net.br/2014/09/chita-chair.html. Acesso em novembro de 2014

http://casavogue.globo.com/Design/noticia/2013/08/antena-biodesign.html. Acesso em novembro de 2014

www.pernambucoconstrutura.com.br/fazendosala/?tag=sergio-j-matos. Acesso em novembro de 2014

www.basesolida.com.br/madeira/tauari-detail. Acesso em novembro de 2014 www.linbrasil.com.br/. Acesso em novembro de 2014

blogs.estadao.com.br/casa/uma-vida-para-o-design/. Acesso em dezembro de 2014 http://www.colegiodearquitetos.com.br/dicionario/2009/02/o-que-e-pilotis/. Acesso em janeiro de 2015. 